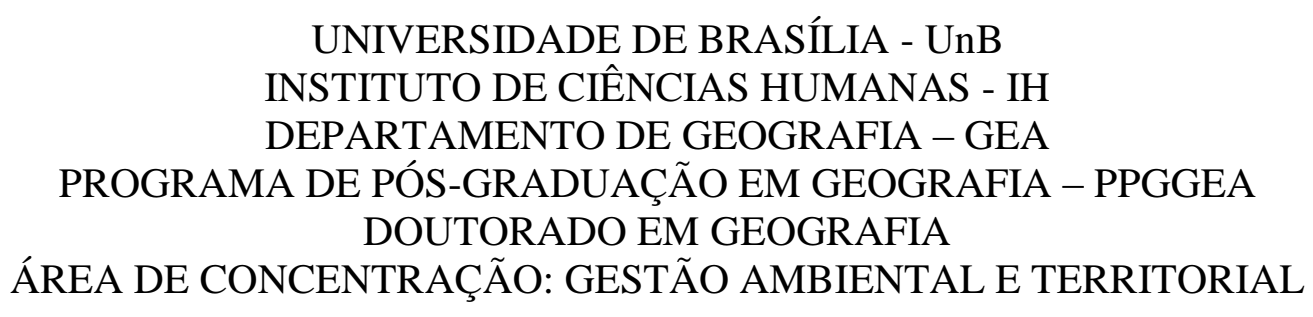

ACUMULAÇÃO FLEXÍVEL E REORGANIZAÇÃO PRODUTIVA DO TERRITÓRIO: O CASO DO PARQUE TECNOLÓGICO CAPITAL DIGITAL DE BRASÍLIA (PTCD)

CLEITON PEREIRA SANTOS TESE DE DOUTORADO 


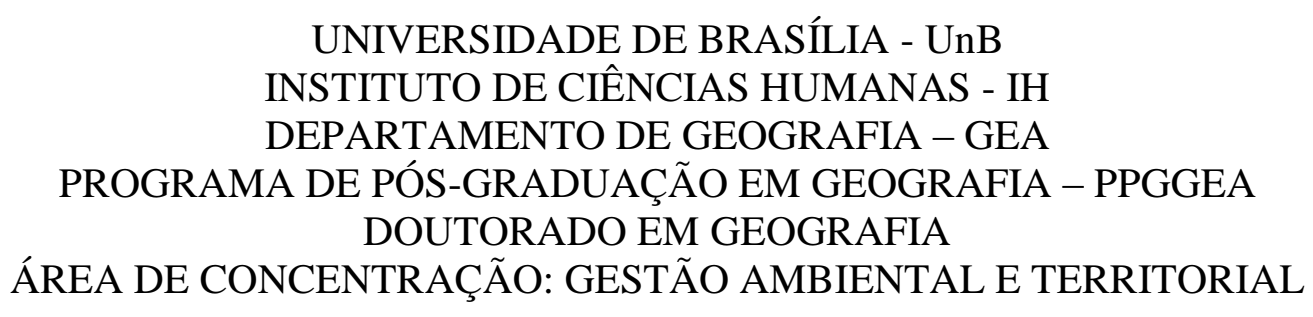

\section{ACUMULAÇÃO FLEXÍVEL E REORGANIZAÇÃO PRODUTIVA DO TERRITÓRIO: O CASO DO PARQUE TECNOLÓGICO CAPITAL DIGITAL DE BRASÍLIA (PTCD)}

CLEITON PEREIRA SANTOS

Orientadora: Prof. Dra. Lúcia Cony Faria Cidade

TESE DE DOUTORADO

Brasília-DF, junho de 2016. 


\author{
UNIVERSIDADE DE BRASÍLIA - UNB \\ INSTITUTO DE CIÊNCIAS HUMANAS - IH \\ DEPARTAMENTO DE GEOGRAFIA - GEA \\ PROGRAMA DE PÓS-GRADUAÇÃO EM GEOGRAFIA - PPGGEA \\ DOUTORADO EM GEOGRAFIA \\ ÁREA DE CONCENTRAÇÃO: GESTÃO AMBIENTAL E TERRITORIAL
}

\title{
ACUMULAÇÃO FLEXÍVEL E REORGANIZAÇÃO \\ PRODUTIVA DO TERRITÓRIO: O CASO DO PARQUE \\ TECNOLÓGICO CAPITAL DIGITAL DE BRASÍLIA (PTCD)
}

Cleiton Pereira Santos

Tese de Doutorado submetida ao Departamento de Geografia da Universidade de Brasília, como parte dos requisitos necessários para a obtenção do Grau de Doutor em Geografia, área de concentração Gestão Ambiental e Territorial.

Aprovado por:

Prof $^{a}$ Dra. Lúcia Cony Faria Cidade - GEA/IH/UnB

(Orientadora)

Prof. Dr. Everaldo Batista da Costa - GEA/IH/UnB

(Examinador Interno)

Prof. Dr. Fernando Luiz Araújo Sobrinho - GEA/IH/UnB

(Examinador Interno)

Prof. Dr. João Nildo Vianna - CDS/UnB e FT/UnB

(Examinador Externo)

Prof. Dr. Sérgio Ulisses Silva Jatobá - CODEPLAN/GDF

(Examinador Externo)

Brasília-DF, junho de 2016. 
Santos, Cleiton Pereira

Acumulação flexível e reorganização produtiva do território: o caso do Parque Tecnológico Capital Digital de Brasília (PTCD) / Cleiton Pereira Santos. Brasília: O Autor, 2016.

$214 \mathrm{f}$.

Tese (Doutorado) - Departamento de Geografia, Universidade de Brasília. Orientadora: Lúcia Cony Faria Cidade.

1.Território usado. 2. Parque Tecnológico. 3. Distrito Federal
I. UnB-GEA.
II. Título
III. Cidade, Lúcia Cony Faria.

É concedida à Universidade de Brasília permissão para reproduzir cópias desta tese e emprestar ou vender tais cópias somente para propósitos acadêmicos e científicos. O autor reserva outros direitos de publicação e nenhuma parte desta tese de doutorado pode ser reproduzida sem a autorização por escrito do autor.

Cleiton Pereira Santos 
Aos meus queridos pais Luiz e Francy, pelo amor, incentivo e carinho. 


\section{AGRADECIMENTOS}

A todos os professores e colegas de curso que contribuíram direta e indiretamente para a realização deste trabalho;

Aos servidores e funcionários dos diversos órgãos de consulta pelo atendimento com presteza e atenção, em especial da TERRACAP e da Secretaria de Ciência, Tecnologia e Inovação;

Aos funcionários do SINFOR, especialmente à Luísa, pela presteza nas informações e pelo contato estabelecido com os empresários do setor de tecnologia da informação e comunicação do Distrito Federal;

À Carolina, funcionária do CDT/UnB pelo atendimento das informações solicitadas;

Aos entrevistados que mesmo diante de seus diversos compromissos diários se dispuseram a prestar as informações necessárias a este estudo, em especial ao Sr. Deputado Federal Izalci Lucas (à época da elaboração do projeto do PTCD, Secretário de Ciência e Tecnologia do Distrito Federal), ao Dr. Claudio Chauke - UCB e, ao Sr. Alteredo Gonçalves, Gerente do Consórcio GBT/DATACENTER BB/CEF do PTCD;

Ao Jorge, Agnelo, Teca e Arthur do Departamento de Geografia sempre dispostos a ajudar na resolução das questões administrativas;

Ao Dr. João Nildo Vianna pela participação na banca examinadora;

Ao Dr. Sérgio Ulisses Silva Jatobá por ter aceitado avaliar o trabalho em um espaço de tempo tão curto;

Ao Prof. Dr. Everaldo Batista da Costa por suas valorosas contribuições na fase do projeto;

A Prof ${ }^{a}$ Dr $^{a}$ Ignez Barbosa Ferreira por suas contribuições teóricas durante as aulas presenciais;

Ao Prof ${ }^{\mathrm{a}}$. Dra . Marília Luiza Peluso por suas contribuições, em vários momentos, ao longo do curso;

Ao Prof. Dr. Fernando Luiz Araújo Sobrinho, pelos notáveis conhecimentos repassados ao longo da minha vida acadêmica e por suas contribuições teóricas fundamentais na fase de qualificação do projeto;

Em especial à Prof $^{\mathrm{a}}$. Dra . Lúcia Cony Faria Cidade, orientadora do trabalho, pela dedicação, estímulo e paciência ao longo deste período. Ressalto aqui a importância do seu rigor metodológico imposto na realização do trabalho que foi primordial a sua realização. Registro aqui a minha grande admiração profissional e pessoal;

Às minhas amigas Ana Izabel Cardoso, Ianaê Cassaro e Patrícia Portilho pela grande amizade e carinho em todos os momentos. 


\section{RESUMO}

O mundo globalizado atual tem produzido formas de expressão espacial da acumulação flexível que são os parques tecnológicos. Estes estão sendo criados para o desenvolvimento econômico, requalificar áreas industriais decadentes ou como instrumentos de planejamento regional. Essa tendência encontra correspondência em dinâmicas que ocorrem fora do país, em cidades brasileiras e em Brasília, no Distrito Federal. O objetivo desta tese é analisar o Parque Tecnológico Capital Digital enquanto forma de expressão espacial da acumulação flexível no território usado de Brasília. Esta análise parte das características dos parques tecnológicos inseridos no contexto do meio técnico-científico informacional enquanto formas espaciais para atender aos interesses hegemônicos da acumulação. Dessa forma, a premissa deste trabalho é que as discussões sobre os parques tecnológicos na reorganização produtiva e espacial, no geral, se restringem ao desenvolvimento econômico, a análise dos fatores decisivos para as empresas inovadoras na escolha da localização. Será feita a análise do Parque Tecnológico Capital Digital nesta perspectiva mas também em outra relacionada as visões dos atores envolvidos. É a partir das intencionalidades destes atores que se verificará como suas ações no território usado têm contribuído para a implementação do Parque Tecnológico Capital Digital. Assim, o processo de implementação do Parque Tecnológico Capital Digital apresenta duas dinâmicas: uma que reforça a sua forma de expressão espacial da acumulação flexível e outra na qual as diferentes visões dos atores envolvidos provocam interesses conflitantes que estão influenciando nos avanços de sua implantação.

Palavras-chave: parque tecnológico, acumulação flexível, território usado, Distrito Federal. 


\begin{abstract}
The current globalized world has produced spatial forms expression of flexible accumulation as technological parks. They are being created for economic development, industrial areas requalify decadent or as instruments of regional planning. This type of dynamic can also be observed in other countries, in brazilian cities and in Brasilia, the Federal District. This thesis aims to analyze the Technology Park Digital Capital while spatial form expression of flexible accumulation in the used territory Brasilia. This analysis of the characteristics of technology parks within the context of informational technical and scientific environment as spatial forms to answer the hegemonic interests of accumulation. Thus, the premise of this thesis that's discussions of technology parks in the production and spatial reorganization in general restricted to economic development, the analysis of the decisive factors for innovative companies in the choice of location. Will be the analysis of Technology Park Digital Capital Brasilia this perspective but also in other related visions of the actors involved. It's from the intentions of those actors who examine how their actions on the used territory have contributed to the implementation of Technology Park Digital Capital Brasilia. Thus, the implementation process of the Technology Park Digital Capital Brasilia has two dynamics: one that enhances your form of spatial expression of flexible accumulation and another in which the different views of the actors involved cause conflicting interests are influencing the progress of its implementation.
\end{abstract}

Keywords: technological park, flexible accumulation, used territory, Federal District. 


\section{LISTA DE FIGURAS}

Figura 3.1 Distribuição dos módulos em projetos de parques tecnológicos .43

Figura 3.2 Vista da Universidade de Stanford e do Silicon Valley - EUA .......................... 50

Figura 3.3 Vista aérea do Cambridge Science Park e do edifício sede ............................... 51

Figura 3.4 Science Park Tsukuba - Japão............................................................................. 55

Figura 3.5 Centro de P\&D e vista aérea do parque Sophia-Antipolis ................................ 58

Figura 3.6 Zhongguancun Science Park - Pequim............................................................... 59

Figura 3.7 Area Science Park -Trieste - Itália .................................................................... 61

Figura 4.1 Distribuição dos parques tecnológicos por Estado - Brasil - 2013 ..................... 88

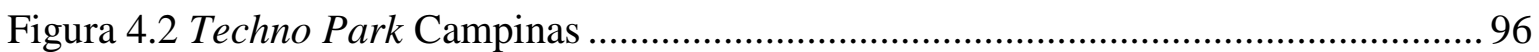

Figura 4.3 Solar da Inovação do São Carlos Science Park .................................................. 97

Figura 4.4 Entrada do edifício sede do parque tecnológico São Carlos Science Park ........ 98

Figuras 4.5 e 4.6 Imagens aéreas do PIM.................................................................... 101

Figura 5.1 Área de influência direta de Brasília ............................................................. 119

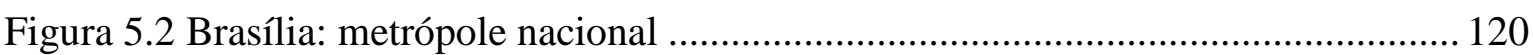

Figura 5.3 Brasília Metropolitana: AMB e RIDE-DF..................................................... 124

Figura 6.1 Agentes de C\&T no Distrito Federal ......................................................... 134

Figuras 6.2 e 6.3 Outras atividades econômicas no SIBS ................................................. 138

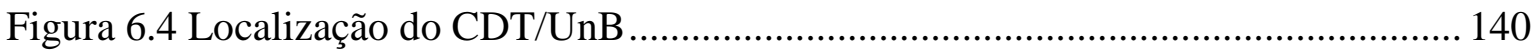

Figura 6.5 Macrozoneamento do Distrito Federal.......................................................... 145

Figura 6.6 Localização do Parque Tecnológico Capital Digital......................................... 146

Figura 6.7 Início das obras no Parque Tecnológico Capital Digital.................................. 148

Figura 6.8 Distribuição dos lotes no PTCD..................................................................... 149

Figura 6.9 Projeção do pórtico de entrada e de prédio no projeto do PTCD...................... 150

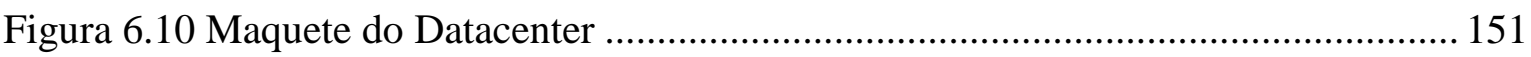

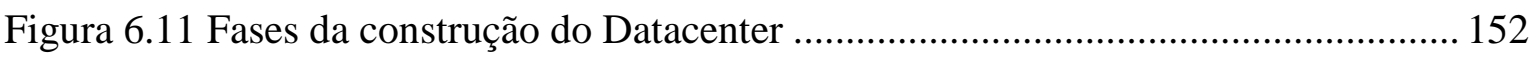

Figura 6.12 Complexo do Datacenter no PTCD ............................................................ 153

Figura 6.13 Distribuição espacial das empresas no PTCD................................................ 156

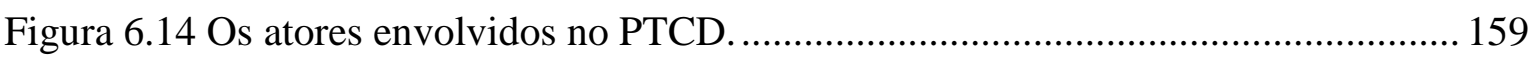

Figura 6.15 Limite atual do PARNA e a questão fundiária da área ................................. 172

Figura 6.16 Imagem aérea do PTCD antes das obras de edificação................................. 181 


\section{LISTA DE FOTOS}

Fotos 6.1 e 6.2 Entrada do Complexo do Datacenter.... 154

Fotos 6.3/6.4/6.5 e 6.6 Construção do edifício sede da Governança do PTCD 155

Foto 6.7 Saída da rede de drenagem do PTCD às margens da via de acesso secundário . 174

Foto 6.8 Área de contenção da rede de drenagem do PTCD............................................. 175

Foto 6.9 Vala recebedora da drenagem pluvial do PTCD ............................................... 176

Fotos 6.10 e 6.11 Área de cascalheira no PTCD ............................................................... 177

Fotos 6.12 e 6.13 Acesso a área da cascalheira no PTCD............................................... 178

Fotos 6.14 e 6.15 Processo erosivo e retirada da cobertura vegetal na cascalheira........... 179

Fotos 6.16 e 6.17 Possíveis danos ambientais do PTCD no território usado ..................... 180

Foto 6.18 Resíduos sólidos de construção na área do PTCD. ........................................... 182

Fotos 6.19 Área de descarte de restos de materiais de construção no PTCD..................... 182 


\section{LISTA DE QUADROS}

Quadro 2.1 Diferenças entre a acumulação intensiva e a acumulação flexível.................... 30

Quadro 3.1 Características dos Parques Tecnológicos ...................................................... 41

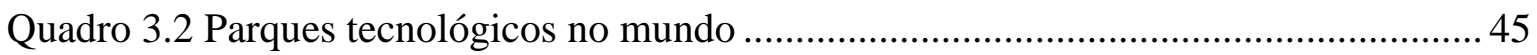

Quadro 4.1 Políticas de Ciência e Tecnologia (1980-2004)................................................ 86

Quadro 4.2 Parques tecnológicos no Brasil...................................................................... 93

Quadro 5.1 Fases da Evolução Demográfica do Distrito Federal (1957-1977) ................ 111

Quadro 6.1 Detalhamento dos agentes componentes da infraestrutura de C\&T no Distrito

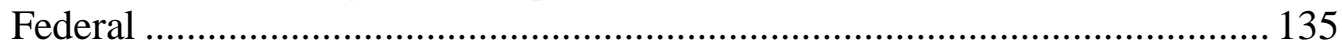

Quadro 6.2 Grandes empresas compradoras de tecnologia em Brasília........................... 137

Quadro 6.3 Atividades desenvolvidas pelas empresas na incubadora CDT/UnB ............. 141

Quadro 6.4 Ações de Gestão no Parque Tecnológico Capital Digital (PTCD).................. 147

Quadro 6.5 Lotes do Parque Tecnológico Capital Digital................................................. 150 


\section{LISTA DE TABELAS E GRÁFICOS}

Tabela 4.1 Número de empresas, custo total, receita líquida e valor adicionado/valor da transformação industrial do setor de Tecnologia da Informação e Comunicação

- TIC - Brasil - 2003-2006.

Tabela 4.2 Participação do setor de Tecnologia da Informação e Comunicação - TIC, no total da economia - Brasil - 2003-2006

Tabela 4.3 Participação dos produtos e serviços de informática no total da receita de serviços de informática - Brasil - 2003-2006 (\%).

Tabela 4.4 Participação de desenvolvimento de softwares sob encomenda e outsourcing no total da receita de serviços de informática - Brasil - 2003-2006 (\%) ............... 92

Tabela 5.1 Pessoas ocupadas no Distrito Federal (1970 e 1983) 107

Tabela 5.2 Domicílios urbanos por classe de renda bruta média mensal (\%) Distrito Federal - 1990

Tabela 5.3 Participação das atividades econômicas no Produto Interno Bruto - Distrito Federal - 1990-1995 (\%)

Tabela 5.4 Evolução Demográfica do Distrito Federal (1960-1996)

Tabela 5.5 Produto Interno Bruto e valor adicionado bruto - Distrito Federal 2003-2011 (R \$ milhão)

Tabela 5.6 Participação das atividades econômicas no valor adicionado bruto - Distrito Federal - 2003-2011 (\%)

Tabela 5.7 Participação do Distrito Federal no Produto Interno Bruto e no valor adicionado bruto no Brasil - 2003-2011 (\%).

Tabela 5.8 Participação do Distrito Federal no Produto Interno Bruto e no valor adicionado bruto no Centro-Oeste - 2003-2011 (\%)

Gráfico 4.1 Projetos de parques tecnológicos no Brasil (2000-2013) .89

Gráfico 5.1 Variação em volume do PIB - Brasil e DF 


\section{LISTA DE SIGLAS}

ACDF

AIST

AMB

ACISJC

ANPROTEC

APLs

APA

ASSESPRO

BNDES

C\&T

CCT

CDI

CDT

CEDIN

CENSOTEC

CIATEC

CIESP

CINE

CLDF

CNDU

$\mathrm{CNPq}$

CODEPLAN

CONPLAN

CONTEC
Associação Comercial do Distrito Federal

National Institute of Advanced Industrial Science and Technology

Área Metropolitana de Brasília

Associação Comercial e Industrial de São José dos Campos

Associação Nacional de Entidades Promotoras de Empreendimentos Inovadores

Arranjos Produtivos Locais

Área de Proteção Ambiental

Federação das Associações das Empresas Brasileiras de Tecnologia da Informação

Banco Nacional de Desenvolvimento

Ciência e Tecnologia

Conselho de Ciência e Tecnologia do Distrito Federal

Conselho de Desenvolvimento Industrial

Centro de Apoio ao Desenvolvimento Tecnológico

Centro de Desenvolvimento de Indústrias Nascentes de São Carlos

Projeto Censo Tecnológico

Centro de Indústrias de Alta Tecnologia

Centro das Indústrias do Estado de São Paulo

Centro Internacional de Negócios e Eventos

Câmara Legislativa do Distrito Federal

Comissão Nacional de Desenvolvimento Urbano

Conselho Nacional de Desenvolvimento Científico e Tecnológico

Companhia de Planejamento do Distrito Federal

Conselho de Planejamento Territorial Urbano do Distrito Federal

Conselho do Polo Tecnológico da Grande Florianópolis 
E\&P Ensino e Pesquisa

EADI Estação Aduaneira Interior

EBTs Empresas de Base Tecnológica

EGTI Estratégia Geral de Tecnologia de Informação

EPIA Estrada Parque Indústria e Abastecimento

FAP Fundação de Apoio à Pesquisa

FECOMÉRCIO Federação do Comércio de Bens, Serviços e Turismo

FIBRA Federação das Indústrias do Distrito Federal

FINEP Financiadora de Estudos e Projetos

FNDCT Fundo Nacional do Desenvolvimento Científico e Tecnológico

GDF Governo do Distrito Federal

IASP International Association of Science Parks

IBTI Instituto Brasília de Tecnologia e Inovação

IBAMA Instituto Brasileiro do Meio Ambiente

IBGE Instituto Brasileiro de Geografia e Estatística

ICMS Imposto sobre Circulação de Mercadorias e Serviços

ICT Instituto de Ciência e Tecnologia

IDEs Investimentos Diretos Estrangeiros

II PND Segundo Plano Nacional de Desenvolvimento

INPE Instituto Nacional de Pesquisas Espaciais

INPI Instituto Nacional de Propriedade Industrial

IPEA Instituto de Pesquisa Econômica Aplicada

ISI Industrialização por Substituição de Importações

JAXA Japan Aerospace Exploration Agency

MCT Ministério da Ciência e Tecnologia

MDIC Ministério do Desenvolvimento da Indústria e Comércio Exterior 
MPOG Ministério do Planejamento, Orçamento e Gestão

NASDA National Space Development Agency

P\&D Pesquisa e Desenvolvimento

PAC Programa de Aceleração do Crescimento

PACTI Programa de Apoio à Capacitação Tecnológica da Indústria

PADCT Programa de Apoio ao Desenvolvimento Científico e Tecnológico

PADES Plano de Apoio ao Desenvolvimento Econômico e Social do Distrito Federal

PBCT

Política Brasileira de Ciência e Tecnologia

PBDCT

Plano Básico de Desenvolvimento Científico e Tecnológico

PDES

Plano de Desenvolvimento Econômico e Social

PDL

Plano Diretor Local

PDOT

Plano Diretor de Ordenamento Territorial

PDTI

Plano Diretor de Tecnologia da Informação

PEA

População Economicamente Ativa

PEC

Planejamento Estratégico de Cidades

PEOT

Plano Estrutural de Organização Territorial do Distrito Federal

PES

Planejamento Estratégico Situacional

PIB

Produto Interno Bruto

PMSJC Prefeitura Municipal de São José dos Campos

PNDR

Política Nacional de Desenvolvimento Regional

PROSECT Programa de Levantamento e Acompanhamento dos Sistemas Estaduais de Ciência e Tecnologia

POT

Plano de Organização Territorial do Distrito Federal

POUSO Plano de Organização e Uso do Solo

PPA Plano Plurianual

PPP Parceria Público-Privada

PRODECON Programa de Desenvolvimento Econômico do Distrito Federal 
Pró-DF Programa de Promoção do Desenvolvimento Econômico Integrado e Sustentável do Distrito Federal

PROIN Programa de Desenvolvimento Industrial do Distrito Federal

PTA Programa de Tecnologias Apropriadas

PTCD Parque Tecnológico Capital Digital

RHAE Programa de Recursos Humanos em Áreas Estratégicas

RIDE Região Integrada de Desenvolvimento do Distrito Federal e Entorno

SAAN Setor de Armazenagem e Abastecimento Norte

SAT Setor de Alta Tecnologia

SCTDE Secretaria de Estado de Ciência, Tecnologia e Desenvolvimento Econômico

SEBRAE Serviço Brasileiro de Apoio às Micro e Pequenas Empresas

SEDS Secretaria de Estado de Economia e Desenvolvimento Sustentável

SEDHS Secretaria de Estado de Desenvolvimento Humano e Social

SIBS Setor Industrial Bernardo Sayão

SIC Secretaria de Indústria, Comércio e Turismo

SINFOR Sindicato das Indústrias da Informação do Distrito Federal

STEMA Secretaria de Tecnologia, Energia e Meio Ambiente

SUDAM Superintendência do Desenvolvimento da Amazônia

SUDECO Superintendência do Desenvolvimento do Centro-Oeste

SUDENE Superintendência do Desenvolvimento do Nordeste

SUDESUL Superintendência do Desenvolvimento do Sul

TERRACAP Companhia Imobiliária de Brasília

TIC Tecnologia da Informação e Comunicação

UCB Universidade Católica de Brasília

UNIVAP Universidade do Vale do Paraíba

WAINOVA World Alliance for Innovation

ZAT Zona de Alta Tecnologia 


\section{SUMÁRIO}

INTRODUÇÃO .16

Capítulo 2

POR UMA CONCEPÇÃO GEOGRÁFICA AO PROCESSO DE ACUMULAÇÃO

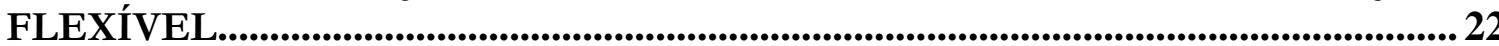

2.1 Do espaço ao território usado 23

2.2 As discussões sobre a acumulação flexível e seus desdobramentos no território usado 28

2.3 As discussões sobre os parques tecnológicos e seus desdobramentos no território usado

Capítulo 3

EXPERIÊNCIAS MUNDIAIS COM PARQUES TECNOLÓGICOS

3.1 Parques tecnológicos: definições e critérios 39

3.2 Primeiras experiências inovadoras no mundo 44

\section{Capítulo 4}

INICIATIVAS DE PARQUES TECNOLÓGICOS NO BRASIL

4.1 O desenvolvimentismo e o cenário produtivo brasileiro até o final dos anos 196064

4.2 Concentração industrial e ações de gestão no território brasileiro

4.3 Políticas econômicas e desenvolvimento produtivo até o início dos anos 1990 .... 72

4.4 Ações de gestão no território brasileiro até o início dos anos 1990 ...................... 74

4.5 Cenário produtivo brasileiro a partir do final dos anos 1990 .............................. 78

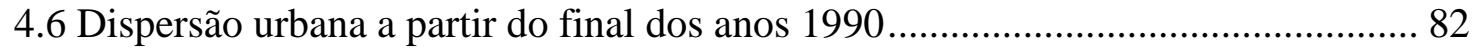

4.7 Experiências brasileiras com parques tecnológicos............................................. 84 


\section{ACUMULAÇÃO FLEXÍVEL E REORGANIZAÇÃO PRODUTIVA}

EM BRASÍLIA

5.1 Consolidação do território usado de Brasília até o final dos anos 1960 104

5.2 A emergência do setor de serviços em Brasília até o início dos anos 1990 106

5.3 Território usado de Brasília até o início dos anos 1990

\section{Capítulo 6}

O PARQUE TECNOLÓGICO CAPITAL DIGITAL DE BRASÍLIA ................... 128

6.1 Contexto da Ciência e Tecnologia em Brasília

6.2 Trajetória do CDT/UnB como difusor de inovação em Brasília

6.4 Intencionalidades dos atores no PTCD: desconstruindo o discurso institucional 157 


\section{INTRODUÇÃO}

O início deste século XXI é marcado pela flexibilidade dos processos de produção e inovações que fazem surgir formas de expressão espacial da acumulação flexível, dentre elas, os parques tecnológicos. Consideraremos que estes são resultantes das práticas dos atores envolvidos nos usos do território. Neste sentido, o tema desta tese é o Parque Tecnológico Capital Digital (PTCD) enquanto forma de expressão espacial da acumulação flexível no território usado de Brasília.

No primeiro momento vamos considerar o meio técnico-científico informacional para caracterizar a importância dos parques tecnológicos na reorganização dos espaços produtivos para atender aos interesses hegemônicos da acumulação flexível a partir da apropriação do conceito de Santos (2006), a tecnosfera. No segundo momento, vamos privilegiar as intencionalidades, as visões dos atores envolvidos na implementação destas formas espaciais, numa apropriação conceitual da psicosfera (SANTOS, 2006).

Neste sentido vamos mostrar que as discussões sobre a importância dos parques tecnológicos na reorganização territorial, no geral, se restringem ao desenvolvimento econômico. Os estudos sobre parques tecnológicos são realizados levando em consideração os fatores decisivos para as empresas inovadoras na escolha da localização. Logo, teremos nesta tese a difícil tarefa de pensar sobre o Parque Tecnológico Capital Digital de duas maneiras. Assim, pretendo deslocar nesta tese a discussão sobre o Parque Tecnológico Capital Digital para a perspectiva dos sujeitos/atores da psicosfera, na tentativa de compreender os efeitos de suas intencionalidades sobre o território usado.

O objetivo geral desta tese é analisar o Parque Tecnológico Capital Digital enquanto forma espacial de acumulação flexível e seu papel no território usado de Brasília. Logo, enfatizo que o fio condutor desta análise é que a implementação de um parque tecnológico é, em geral, analisada sob a perspectiva econômica. A implementação do Parque Tecnológico Capital Digital está relacionada também com outra perspectiva, as visões dos atores envolvidos.

Assim, a questão que se coloca como problema relativo ao objeto específico desta pesquisa é precisamente esta: quais são as visões dos atores envolvidos na implementação do Parque Tecnológico Capital Digital no território usado de Brasília? E vamos mais especificamente questionando, quem são estes atores? Quais são as suas ações? 
Dessa forma, vamos sustentar a partir de Santos (1996, p. 77) que o território usado é uma totalidade concreta compreendida através dos eventos. Os eventos são a geografização de objetos e ações por intencionalidades de impregnar o território com determinadas funções (usos). Assim, o território que consideraremos aqui não é o território, base geográfica, mas o território usado, conceito que irá nos permitir considerar conjuntamente objetos e ações numa lógica espaço-tempo, possibilitando um raciocínio geográfico para a compreensão do nosso objeto de estudo, o Parque Tecnológico Capital Digital.

Vamos considerar ainda que a realidade, o momento presente, está relacionada com o desenvolvimento de fases (movimento passado-presente-futuro). Os eventos têm como âncora o passado, condição dada pelo território para a sua realização e o futuro, pois os eventos modificam a realidade presente contribuindo para criar condições para novos eventos $^{1}$. A partir desse movimento no território usado (passado-presente-futuro) realiza-se a periodização do objeto e foi desta forma que construímos esta tese. Assim, considerando esta periodização (passado-presente) vamos partir de uma visão mais geral até chegar ao objeto.

As primeiras experiências com parques tecnológicos no mundo surgiram da iniciativa de empresas privadas próximas de centros de pesquisa e excelência. Outras experiências se organizaram sob a forma de parcerias entre universidades de instituições financiadoras e, outras surgiram atraídas pelos benefícios locais oferecidos. Como formas espaciais da acumulação flexível estes parques tecnológicos surgiram para promover o desenvolvimento econômico ou requalificar áreas industriais decadentes ou estagnadas. Surgiram ainda, como políticas regionais locais de planejamento.

No Brasil, após décadas em um processo de industrialização intensiva, os parques tecnológicos surgiram como tentativas de inserção na acumulação flexível e ao mesmo tempo com alternativas de desenvolvimento econômico regional/local. Com os avanços do setor terciário no país têm sido implementados para a produção de inovações. As suas localizações, em sua maioria, coincidem com as áreas de industrialização concentrada do centro econômico polarizador do país na região Sudeste.

Brasília, no Distrito Federal, a cidade capital com funções predominantemente terciárias, além do seu papel geopolítico desenvolveu nas últimas décadas o seu papel de dinâmico tornando-se núcleo propulsor de ampla região de influência. Ao articular-se com

\footnotetext{
1 Apropriação conceitual de Milton Santos (1999, p.44).
} 
as cidades de seu entorno imediato tornou-se o centro de empregos e serviços e o core de um conjunto metropolitano. Brasília, com função de metrópole, no momento atual, procurando criar uma matriz produtiva para atender o crescimento do setor de serviços avançados tem buscado desenvolver em seu território usado formas espaciais de inovação. Assim, o planejamento governamental localizou o Parque Tecnológico Capital Digital de Brasília - PTCD, nas adjacências do Parque Nacional de Brasília, na Região Administrativa I, que abriga o Plano Piloto, para o desenvolvimento de inovações nas áreas de tecnologia da informação e comunicação. O projeto do Parque Tecnológico Capital de Brasília foi elaborado em 2002 e encontra-se em fase de implantação.

Com base nestas considerações, a tese é constituída de cinco Capítulos interrelacionados. No Capítulo 2, Por uma concepção geográfica ao processo de acumulação flexível são apresentadas as discussões a partir do espaço. Partindo de uma perspectiva da Geografia crítica de David Harvey e Milton Santos estabelecemos a base conceitual do território usado e suas apropriações na acumulação flexível. Abordamos também as discussões sobre os parques tecnológicos e seus desdobramentos no território usado, partindo de uma visão de desenvolvimento econômico característica dessa forma de expressão espacial da acumulação flexível.

No Capítulo 3, são apresentadas as principais características dos parques tecnológicos, suas áreas de inovação, espécies, objetivos, requisitos e recursos para a sua implementação. Na sequência, no Capítulo, são apresentadas algumas experiências com parques tecnológicos no mundo com destaque aos parques tecnológicos no Reino Unido para a exposição do modelo teórico da importância dos fatores de decisão das empresas para localização nos parques tecnológicos. Teoria esta indispensável numa análise sobre parques tecnológicos no meio técnico-científico-informacional.

No Capítulo 4, apresentamos o cenário produtivo brasileiro e os usos do território e algumas experiências com parques tecnológicos no Brasil. Para discorrer sobre o cenário socioeconômico brasileiro utilizamos a periodização proposta por Diniz; Crocco (2006) em três fases. A partir desta periodização são levantadas as características socioeconômicas brasileiras até a atualidade e os resultados das ações no território usado, sendo estas o cenário para o estudo da implantação dos parques tecnológicos no Brasil. As experiências com parques tecnológicos são expostas levando em consideração que inicialmente surgem como alternativas de crescimento econômico regional/local. Com a emergência do setor terciário no país, passam a ser meios inovadores a produção. Na atualidade, são meios inovadores para a consolidação de um setor terciário avançado. 
Seguindo a mesma periodização do Capítulo anterior tentamos delinear no Capítulo 5 o cenário socioeconômico de Brasília. A análise procura mostrar o deslocamento da atividade produtiva de Brasília da atividade administrativa funcional de Capital do país para as atividades terciárias e a consolidação de seu território usado até a constituição de sua área metropolitana, com ênfase no caráter concentrador das atividades no núcleo da cidade central (Plano Piloto) e ao mesmo tempo o movimento de expansão em seu território usado. Assim, os Capítulos 3, 4 e 5 apresentam as discussões sobre os parques tecnológicos numa perspectiva econômica do meio técnico-científico na qual estão inseridos os cenários produtivos brasileiro e de Brasília.

No Capítulo 6 desta pesquisa, O Parque Tecnológico Capital Digital de Brasília é que consolidamos o objetivo do trabalho e verificamos de maneira mais aprofundada a problemática da tese. O Capítulo está dividido em quatro tópicos que contribuem para a sistematização dos resultados a partir das questões de pesquisa. Inicialmente são apresentadas as características da Ciência e Tecnologia em Brasília para enfatizar que a emergência do setor terciário avançado necessita de formas espaciais específicas para a produção de inovações demandadas por este setor e como exemplo disso, uma primeira experiência, o Centro de Apoio ao Desenvolvimento Tecnológico da Universidade de Brasília - CDT/UnB e a concepção do Parque Tecnológico Capital Digital. Na sequência, são apresentadas os resultados na tentativa de responder à questão de pesquisa sobre as intencionalidades dos atores no Parque Tecnológico Capital Digital.

O processo de implantação do Parque Tecnológico Capital Digital aponta em duas direções. Se por um lado reforça as características da acumulação flexível com os fatores decisivos para as empresas inovadoras na escolha da localização, por outro lado, mostra que as diferentes visões dos atores envolvidos provocam interesses conflitantes que estão influenciando em seu processo de implantação. 


\section{Aspectos metodológicos}

Esta pesquisa teve por objetivo analisar o Parque Tecnológico Capital Digital de Brasília (PTCD) enquanto forma de expressão espacial da acumulação flexível no território usado de Brasília, no Distrito Federal na década atual. A pesquisa buscou os aspectos relevantes para a análise em três períodos: a) até o início dos anos de 1960; b) até o início de 1990 e; c) a partir dos anos 1990. Os períodos foram estabelecidos com base nas fases apontadas por Diniz; Crocco (2006, p.10), a primeira delas, após a Segunda Guerra Mundial, até os anos 1970, denominada política desenvolvimentista, a segunda, a partir dos anos 1970, denominada fase neoliberal ortodoxa e a terceira, a partir do final dos anos 1990, uma fase denominada neodesenvolvimentista.

A hipótese de trabalho que serve de guia à pesquisa foi: a implantação do Parque Tecnológico Capital Digital está relacionada a dinâmicas socioeconômicas amplas e a processos específicos que incluem perspectivas de diferentes atores.

Para tentar responder as questões de pesquisa realizamos pesquisa documental e bibliográfica, entrevistas com os atores envolvidos e, trabalhos de observação no campo. A tese foi estruturada em torno de quatro questões de pesquisa, que orientam o desenvolvimento de cada capítulo. Enquanto as primeiras têm caráter mais geral e por vezes contextual, a última leva aos aspectos mais específicos, aproximando o texto progressivamente ao foco.

A primeira questão foi: quais as características dos parques tecnológicos no processo de acumulação flexível que contribuíram para as primeiras experiências inovadoras no mundo? Para responder a esta questão foi realizada pesquisa documental e bibliográfica para levantamento dos aspectos dos parques tecnológicos, enfatizando os diversos pensamentos sobre a temática, o seu estágio atual e os seus impactos na reorganização produtiva de forma mais abrangente e com base nas experiências internacionais favoráveis à sua implementação.

A segunda questão foi: em que medida a acumulação flexível e os parques tecnológicos influenciam na reorganização territorial urbana e metropolitana no Brasil? Para tentar responder esta questão de pesquisa foi realizada uma revisão bibliográfica e documental para apresentar um panorama geral dos aspectos socioeconômicos no Brasil, com a ênfase na reorganização produtiva e urbana, aproximando para o tema específico que são os parques tecnológicos e as suas experiências no território usado brasileiro. 
A terceira questão, em que medida a acumulação flexível e a dinâmica terciária se refletem na reorganização territorial urbana e metropolitana em Brasília? foi também respondida por meio de pesquisa documental. Foram analisados ainda, artigos, periódicos atuais e os planos de desenvolvimento econômico e ordenamento territorial do Distrito Federal, principalmente o atual, o Plano Diretor de Ordenamento Territorial PDOT (2012) objetivando esclarecer o avanço do setor de serviços em Brasília.

Para a quarta questão, quais as visões dos atores envolvidos na implantação do Parque Tecnológico Capital Digital? foi realizada pesquisa documental e buscamos fontes para a compreensão do projeto técnico e de instalação no Memorial Descritivo do Parque Tecnológico Capital Digital de Brasília da TERRACAP (2009). Foram ainda realizadas entrevistas com alguns atores envolvidos no processo de implementação do parque e trabalhos de observação na área do parque.

As entrevistas foram de fundamental importância para a análise das intencionalidades dos atores envolvidos na implementação do Parque Tecnológico Capital Digital. Foram entrevistados, empresários do setor de inovação (tecnologia da informação e comunicação), gestores governamentais (secretários de governo, políticos), pesquisadores, trabalhadores da construção civil no parque, a comunidade local e outros representantes. Essas entrevistas foram semiestruturadas, ou seja, com um roteiro previamente estabelecido permitindo o contato entre entrevistado e o entrevistador, podendo este formular perguntas a partir do entrevistado, possibilitando maior espaço para questões abertas e assim um levantamento de dados primários qualitativos.

Em conjunto com as entrevistas foram realizados trabalhos de campo na área do Parque Tecnológico Capital Digital, na comunidade local, e no setor industrial Bernardo Sayão. Estes levantamentos de campo serviram para a compreensão dos fenômenos abordados na revisão da literatura e nas entrevistas, com a observação da realidade no parque. Estes levantamentos foram uma admirável busca do entendimento da totalidade espaço-tempo do objeto estudado e suas interferências no território usado de Brasília.

Dessa forma, entendemos pertinente apresentar esta Introdução com as principais nuances e a estrutura da tese. Segue então, uma concepção geográfica ao processo de acumulação flexível como aporte teórico para sustentar a tese desenvolvida. 
Capítulo 2

\section{POR UMA CONCEPÇÃO GEOGRÁFICA AO PROCESSO DE ACUMULAÇÃO FLEXÍVEL}

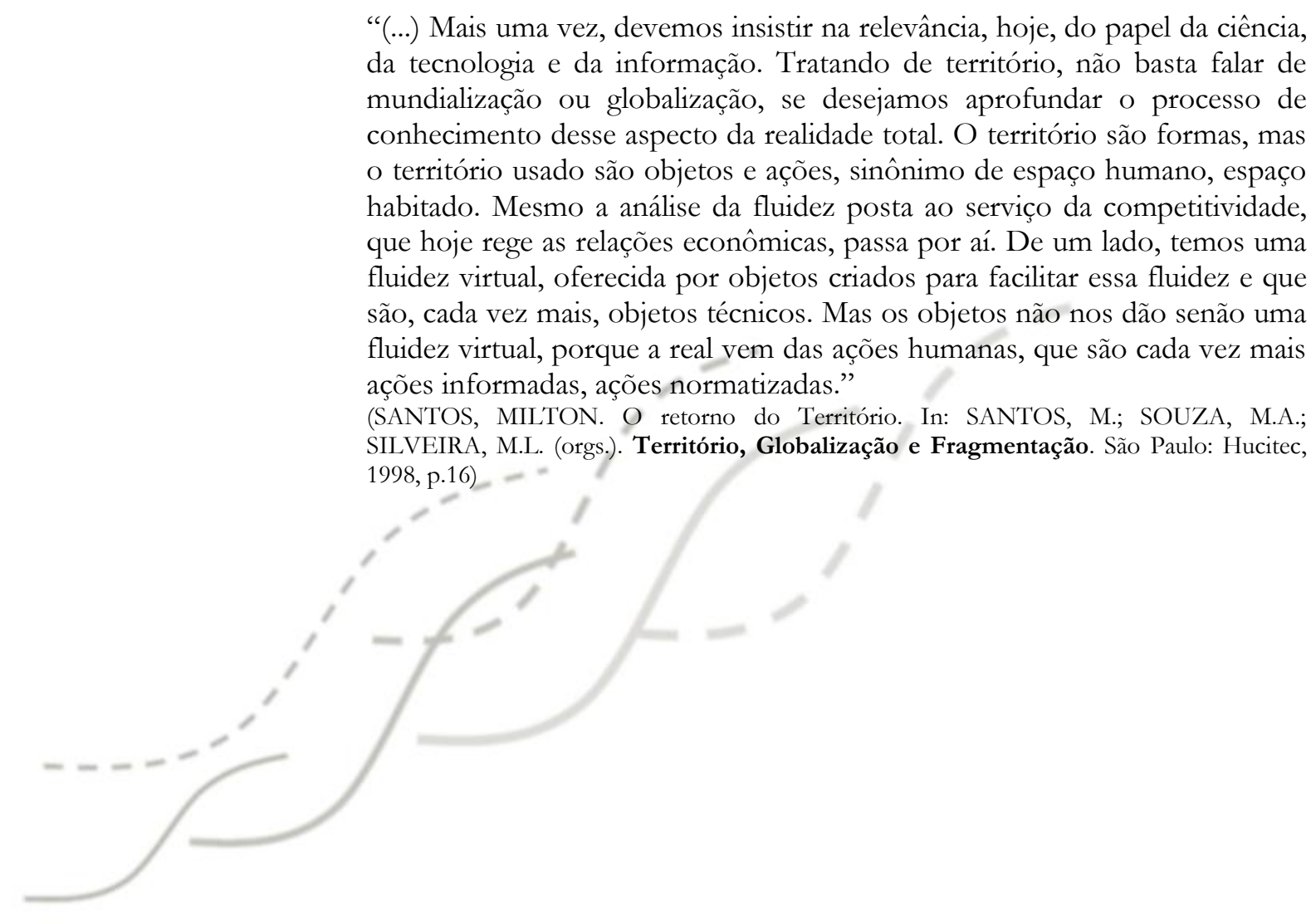




\subsection{Do espaço ao território usado}

A Ciência Geográfica do século XIX refletiu o contexto mundial da época articulada com outras Ciências modernas e a Filosofia. De acordo com Cidade (2001, p. 166), a dicotomia impregnada nos pensamentos vigentes atingiu consideravelmente a Ciência Geográfica, que por um lado buscava sistemas interpretativos totalizantes, com a natureza identificada com este todo, por outro, em direção a um racionalismo, baseado na separação sujeito/objeto e na externalização da natureza. Essa permaneceu até o início do século XX, na tentativa de manter a condição de Ciência e a busca por formulações integradoras.

A dualidade presente no pensamento geográfico e a dificuldade de reconhecer o homem nas suas relações sociais e nas relações de produção fez surgir na segunda metade do século XX, uma Geografia de posicionamento crítico em relação ao modo de produção capitalista de acumulação flexível na pós-modernidade. Nessa fase, os trabalhos invariavelmente começam pela crítica do projeto clássico da Geografia, pois a concepção de fenômenos únicos impede qualquer esforço em direção a uma explicação teóricocientífica. Concordam os pesquisadores nesta fase em reconhecer que a singularidade dos fatos geográficos é incompatível com a visão científica moderna. O objetivo desses críticos é o de se fazer da Geografia uma ciência, ou seja, um conhecimento moderno do mundo. Destacam-se nessa perspectiva os trabalhos de David Harvey e Milton Santos.

Harvey $(2005$, p. 54) reconstrói a teoria marxista levando em consideração a dimensão espacial, afirmando que as relações espaciais e a estrutura geográfica não podem ser reduzidas a uma teoria do Estado. Propõe o utopismo dialético, uma forma de utopismo espaço temporal em que o processo de produção destas duas dimensões terão de ser incorporados ao pensamento utópico. Para o autor, a transformação na experiência humana do espaço e do tempo foi uma das mais relevantes mudanças ocorridas com transição do fordismo para a acumulação flexível, a globalização.

A variação da compreensão do tempo e do espaço afeta inclusive os valores individuais e os processos sociais. Destaca o autor a acepção segundo a qual o espaço pode ser tomado como relativo, ou relacional, como estando contido em objetos, no sentido de que um objeto existe somente na medida em que contém e representa dentro de si próprio as relações com outros objetos (HARVEY, 1980, p. 04). Assim, o espaço geográfico, de acordo com Harvey é um ambiente construído com diferentes configurações a partir de uma relação dialeticamente precisa. 
Santos (1978, p. 54) afirma que a Ciência Geográfica na busca por novas interpretações e caminhos se posiciona de forma crítica, direcionando sua contribuição para resgatar a importância do espaço no mundo atual. Nessa perspectiva de valorização do espaço torna-se necessário compreendê-lo enquanto objeto de estudo geográfico.

O espaço é um conjunto de relações realizadas através de funções e de formas que se apresentam como testemunho de uma história escrita por processos do passado e do presente. Isto é, o espaço se define como um conjunto de formas representativas de relações sociais do passado e do presente e por uma estrutura representada por relações sociais que estão acontecendo diante dos nossos olhos e que se manifestam através de processos e funções. O espaço é, então, um verdadeiro campo de forças cuja aceleração é desigual. Por isso, a evolução espacial não se faz de forma idêntica em todos os lugares (SANTOS,1978, p.122).

O espaço é um fato social que define os fenômenos sociais, sendo um fato histórico na medida em que é reconhecido como elemento de um conjunto. Ele realiza uma dupla função que lhe assegura, efetivamente, a condição de fato histórico: além de definir o conjunto, ele é simultaneamente produtor e produto sendo, portanto, um revelador que permite ser decifrado por aqueles mesmos a quem revela e ao mesmo tempo, em que adquire uma significação autêntica, atribui um sentido a outras coisas. Segundo essa acepção o espaço é um fato social, um fator social e uma instância social (SANTOS, 1978, p.130).

O espaço como um fato social, produto da ação humana, tem uma natureza socializada que, por sua vez interfere no processo social não apenas pela carga de historicidade passada, mas também pela carga inerente de historicidade possível de ser construída, na medida em que é considerado uma instância de determinação do movimento real de transformação da história a ser construída.

Neste sentido, Soja (1993, p.99) explica que a estrutura do espaço organizado não é uma estrutura separada, com suas leis autônomas de construção e transformação, nem tampouco é uma expressão da estrutura de classes que emerge das relações sociais de produção. Ela representa, ao contrário, um componente dialeticamente definido das relações de produção gerais. Estas relações são simultaneamente sociais e espaciais.

De acordo com Santos (1985, p. 49) o espaço constitui uma realidade objetiva, um produto social em permanente processo de transformação. O estudo do espaço requer a compreensão de sua relação com a sociedade, porque é ela quem dita a compreensão dos efeitos dos processos (tempo e mudança) e especifica as noções de forma, função e 
estrutura, elementos fundamentais para o entendimento da produção de espaço. As transformações que ocorrem na sociedade repercutem nas formas ou objetos geográficos, e estes assumem novas funções, produzindo uma nova organização espacial.

O espaço geográfico funciona sistemicamente, como um conjunto indissociável, solidário e também contraditório, de sistemas de objetos e sistemas de ações que, não podem ser considerados isoladamente, mas sim como o quadro único no qual a história se dá (SANTOS, 2003, p. 63). O espaço é um conjunto de fixos e fluxos que interagem (SANTOS, 1999, p. 50). O espaço é aquilo que resulta da relação entre a materialidade das coisas (objetos) e a vida que as animam e transformam (ações).

A análise espacial continua a ser considerada o caminho para o entendimento das relações produtivas, sociais, forçando a adaptação da sociedade aos avanços por ela identificados. É preciso romper com a visão do espaço na modernidade e na pósmodernidade, sempre visto com morto, fixo e atemporal numa abordagem alternativa.

Assim, Massey (2008) pensa sobre o espaço a partir de um outro conjunto de ideias, como inter-relação, contemporaneidade dinâmica, abertura radical e heterogeneidade. O espaço é visto com produto de inter-relações, como a esfera da possibilidade de existência da multiplicidade e com sempre em construção e, portanto, aberto, inacabado.

Essa abordagem alternativa do espaço é colocada por Massey (2008, p. 29) em três proposições: primeiro, reconhecemos o espaço como produto de inter-relações, como sendo constituído através de interações, desde a imensidão global até o intimamente pequeno; segundo, compreendemos o espaço como a esfera da possibilidade da existência da multiplicidade, no sentido da pluralidade contemporânea, com a esfera na qual distintas trajetórias coexistem; terceiro, reconhecemos o espaço com estando sempre em construção.

Para Massey, o espaço apresenta o social em seu mais amplo sentido: o desafio da interrelacionalidade constitutiva e assim, a implicação coletiva nos resultados dessas interrelacionalidade, a contemporaneidade radical de uma multiplicidade de outros humanos e não-humanos, em processo. O espaço torna-se relacional, ou seja, uma esfera de possibilidades da existência (2008, p.52).

Uma abordagem do espaço deve privilegiar o reconhecimento da contemporaneidade de múltiplas trajetórias históricas que se cruzam, se conectam e se desconectam, formando assim o espaço a partir dessas relações. Assim, o espaço torna-se aberto, múltiplo e relacional. A multiplicidade é fundamental para a geração da temporalidade para haver multiplicidade tem que ocorrer espaço. Espaço e tempo apesar de 
distintos são indissociáveis (MASSEY, 2008, p. 144). Para Raffestin (1993, p.132) o espaço é anterior ao território.

O conceito de território não deve ser confundido com o de espaço ou de lugar, estando muito ligado à ideia de domínio ou de gestão de uma determinada área. O território é fundamentalmente um espaço definido e delimitado por e a partir de relações de poder (SOUZA, 1995, p.78). Segundo Raffestin (1993, p.144), o território é um espaço onde se projetou um trabalho, seja energia e informação, e que por consequência, revela relações marcadas pelo poder e de apropriação de um espaço produzido.

O território implica um determinado uso do espaço, consubstanciado em mecanismos de apropriação, de controle e defesa por agentes públicos e privados, através dos quais se viabilizam práticas de poder e implica ainda, a ideia de um dado recorte espacial, envolvendo áreas geográficas específicas, que representam parcelas ou domínios territorializados (DAVIDOVICH, 1991, p.08).

Retomando as considerações de Santos (1996) a Ciência Geográfica tem por objeto o espaço geográfico que é um sistema indissociável de objetos e ações. A empirização deste sistema indissociável que configura os usos do território. Assim, a Geografia parte da tentativa de compreender o território usado, ou seja, seus usos realizados, o próprio "território vivo" (SANTOS, 1999, p. 111). Santos; Silveira (2001, p. 21) indicam que os usos do território podem ser definidos pela implantação de infraestruturas que dão dinamismo à economia e a sociedade. Esses usos são os movimentos da população, a distribuição dos serviços, da indústria e da agricultura.

Esses usos do território são essencialmente dotados de técnica, ciência e informação. Santos (1996) os definem como pertencentes ao meio técnico-científicoinformacional, caracterizado pela intensa inserção da técnica com a ciência e a informação na constituição dos objetos técnicos e na realização das ações. Na prática se constitui num aumento constante da precisão, da racionalidade e das intencionalidades ${ }^{2}$ de invenção técnica para os usos do território.

Inicialmente trataremos nesta análise o meio técnico-científico-informacional pela apropriação conceitual que Milton Santos (1997) faz da tecnosfera, afirmando ser esta uma requalificação espacial para atender aos interesses hegemônicos da acumulação. No Capítulo 06 a ênfase será na psicosfera que segundo Santos (1997, p. 204) é o reino das ideias, crenças, paixões e lugar da produção de sentido e o conteúdo da mente para levar à

\footnotetext{
2 As intencionalidades nos usos do território serão retomadas na discussão do Capítulo 06, quando da apresentação das visões dos atores envolvidos no PTCD.
} 
compreensão de como as intencionalidades dos atores sociais interferem em suas práticas de usos do território. O que interessa discutir é, então, o território usado, apontando para a necessidade de um esforço destinado a analisar sistematicamente a constituição do território, considerando este empirizável, surgindo daí o seu enriquecimento teórico necessário a esta Tese.

Santos (1996, p. 76) afirma que o território usado é uma totalidade concreta compreendida através dos eventos (SANTOS, 1996, p. 76). A totalidade concreta é um conceito fundamental à compreensão do território usado. Kosik (1969, p. 43) afirma que a totalidade não se remete a todos os fatos. A totalidade significa a realidade com um todo estruturado, dialético, no qual ou do qual um fato qualquer pode vir a ser racionalmente compreendido.

Os eventos segundo Santos (1996, p. 77) ocorrem na realidade como totalidade concreta, resultantes de um feixe de vetores, conduzidos por um processo, levando nova função ao meio pré-existente, só se completando quando integrado ao meio. Os eventos são dessa forma, a geografização de objetos e ações numa interdependência dada por uma racionalidade da existência, ou seja, por intencionalidades de impregnar o território com determinadas funções (usos).

Santos (1996, p. 44) afirma que os eventos são a empirização do tempo, enquanto uso do território, tendo como âncoras o passado (condição dada pelo território para a sua realização) e o futuro (pois os eventos modificam a realidade presente, contribuindo para criar condições para novos eventos na dinâmica do território). Os eventos são resultantes da realidade em movimento. Portanto o território usado encontra-se em permanente transformação segundo o sentido e a essência dos eventos que abarca.

Não se trata então o território de um espaço inerte, uma plataforma apenas sobre o qual os homens exercem a história (SANTOS, 2007, p. 24). O território com o qual vamos trabalhar nesta Tese, não é o território em si, mas o território usado, conceito que elimina a possibilidade de considerar separadamente objetos e ações e possibilita um raciocínio geográfico para a compreensão do nosso objeto de estudo, o Parque Tecnológico Capital Digital de Brasília.

Considerando essas visões do território usado prossigamos no entendimento das mudanças produtivas no capitalismo, seus processos de acumulação e as suas principais características no contexto atual. 


\subsection{As discussões sobre a acumulação flexível e seus desdobramentos no território usado}

As aceleradas mudanças no mundo atual globalizado, trazem ao questionamento de um tema que suscita amplos debates: o regime de acumulação ${ }^{3}$. De encontro com a proposta de análise desta Tese, que é o parque tecnológico Capital Digital de Brasília, inicialmente torna-se importante a discussão desse regime de acumulação, especialmente o flexível. Adianto que a premissa é que os parques tecnológicos são formas de expressão espacial da acumulação flexível e resultados das práticas dos atores envolvidos nos usos do território. Antes da discussão em torno da acumulação flexível fazse necessário contextualizar o regime de acumulação anterior que entrou em crise por volta dos anos de 1970 do século passado, o fordismo ou acumulação intensiva.

O marco inicial simbólico do Fordismo é no ano de 1914, quando Henry Ford introduziu em sua linha de montagem de automóveis, em Michigan, nos Estados Unidos da América, o pagamento de cinco dólares por oito horas diárias como recompensa aos seus trabalhadores. Apesar de vários teóricos discorrerem que Ford apenas racionalizou princípios da administração taylorista ${ }^{4}$, sua visão de que a produção de massa significava consumo de massa, foi fundamental a este regime de acumulação intensiva. Ford preconizou a importância do poder corporativo de regulamentação e uma ênfase na funcionalidade e eficiência (HARVEY, 2014, p.120).

Aglietta (1979) apud (CIDADE; JATOBÁ; VARGAS, 2008, p. 23) afirma que no fordismo o trabalho assalariado se universalizou num processo de produção articulado ao consumo de massa. Entre a principais transformações deste regime destacam-se as mudanças significativas nos processos de trabalho e nas condições de vida dos trabalhadores, entre as quais o aumento do nível de consumo e uma maior atuação dos sindicatos em torno dos interesses coletivos. Por outro lado, havia um alto grau de especialização de tarefas, pouco ou nenhum treinamento no trabalho, organização vertical do trabalho e pouca segurança na execução das tarefas.

Quanto à interferência na organização espacial mundial, o fordismo propiciou a expansão da industrialização nos países avançados e um aumento significativo das

\footnotetext{
${ }^{3}$ De acordo com Lipietz (1986) e outros autores, um regime de acumulação descreve a estabilização por um longo período, da alocação do produto líquido do consumo e acumulação. Esta conceituação varia de uma escola de pensamento denominada escola da regulamentação, tendo como precursor Aglietta (1979).

${ }^{4}$ A administração taylorista elaborada por Frederic Taylor é um sistema de organização do trabalho no qual se pretende obter o máximo da produção no mínimo tempo possível.
} 
populações vivendo em cidades e áreas metropolitanas. Estes países possuíam ou tinham capacidade para suporte territorial e infraestrutura em nível suficiente para dar condições à acumulação intensiva em parte concentrada em complexos industriais. Nos países periféricos ${ }^{5}$ que adotaram o processo de substituição de importações como possíveis alternativas ao desenvolvimento houve menos condições de absorver este regime de acumulação intensiva ${ }^{6}$. Dessa forma, o fordismo se estabeleceu de forma desigual tantos nos processos de acumulação (intensiva nos países avançados e de substituição nos periféricos) como da configuração territorial dele resultante (CIDADE; JATOBÁ; VARGAS, 2008, p. 23).

Com o acirramento destas desigualdades houve uma profunda crise em 1973, marcada principalmente pelo choque do petróleo, colocando em incertezas e oscilações os ideais enraizados pelo fordismo. É neste contexto de crise que surge a acumulação flexível ${ }^{7}$ em oposição à rigidez fordista. Harvey (2014, p.140) afirma que esta se baseia da flexibilidade dos processos de trabalho, dos mercados de trabalho, dos produtos, dos padrões de consumo, das novas maneiras de fornecimento de serviços financeiros, novos mercados e principalmente taxas altamente intensificadas de inovação comercial, tecnológica e organizacional.

Swyngedouw (apud Harvey, 2014, p. 164) afirma que houve a integração dos mercados e a descentralização da produção. Houve uma substituição da produção de massa e de camadas estanques por hierarquias mais niveladas nas empresas, com ênfase na comunicação e não em comando, por meio da desintegração vertical. Ocorreu também um aumento da terceirização, das franquias e do marketing entre empresas, bem como a extinção de funções e o aumento do número de trabalhadores em tempo flexível, parcial e temporário, autônomos ou dos que trabalham em casa.

Estas características são apresentadas no Quadro 2.1 mostrando o contraste entre os dois regimes de acumulação. O processo de produção em massa de bens homogêneos é substituído pela produção em pequenos lotes, diminuindo a uniformidade e a padronização tornando mais flexível a produção. No trabalho a realização de uma única

\footnotetext{
${ }^{5}$ Numa perspectiva de integração ao processo de acumulação, vamos considerar estes países como em desenvolvimento, apesar de na contribuição teórica de Harvey se denominarem "periféricos" por estarmos tratando neste ponto de um etapa anterior que o autor denomina fordismo periférico.

${ }^{6}$ No Capítulo 04 serão discutidas estas condições no caso brasileiro e suas implicações na organização territorial.

7 Alguns autores como Kumar (1997) denominam este regime de acumulação como Pós-fordista ou produção just-in-time baseada em economias de escopo.
} 
tarefa pelo trabalhador é substituída por múltiplas tarefas e longo treinamento para a execução destas.

A acumulação flexível proporciona um novo processo de produção com o refinamento das funções, a diversificação/especialização produtiva. Sob a ótica da organização do trabalho, ocorre a flexibilização norteada pela rápida adaptação aos novos sistemas de operação, a desintegração vertical das empresas com a redução do tempo e custo de reprogramação dos equipamentos. Estas características são apresentadas no Quadro 2.1 mostrando o contraste entre os dois regimes de acumulação.

Quadro 2.1 Diferenças entre a acumulação intensiva e a acumulação flexível

\begin{tabular}{|c|c|c|}
\hline Modalidade & Acumulação intensiva & Acumulação flexível \\
\hline \multirow{5}{*}{$\begin{array}{l}\text { Processo de } \\
\text { Produção }\end{array}$} & Produção em massa & Produção em pequenos lotes \\
\hline & Uniformidade e padronização & Produção flexível \\
\hline & Grandes estoques & Sem estoques \\
\hline & Voltada para os recursos & Voltada para a demanda \\
\hline & Integração vertical e horizontal & $\begin{array}{l}\text { Integração quase vertical } \\
\text { Subcontratação }\end{array}$ \\
\hline \multirow{5}{*}{ Trabalho } & Única tarefa pelo trabalhador & Múltiplas tarefas \\
\hline & Alto grau de especialização de tarefas & Eliminação de tarefas \\
\hline & $\begin{array}{l}\text { Pouco ou nenhum treinamento no } \\
\text { trabalho }\end{array}$ & Longo treinamento no trabalho \\
\hline & Nenhuma aprendizagem & Aprendizagem \\
\hline & Nenhuma segurança no trabalho & $\begin{array}{l}\text { Grande segurança no emprego } \\
\text { Nenhuma segurança para temporários }\end{array}$ \\
\hline \multirow[t]{3}{*}{ Espaço } & $\begin{array}{l}\text { Especialização funcional } \\
\text { Centralização } \\
\text { Descentralização }\end{array}$ & $\begin{array}{l}\text { Agregação } \\
\text { Aglomeração }\end{array}$ \\
\hline & Divisão do trabalho & 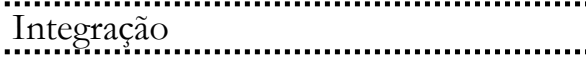 \\
\hline & $\begin{array}{l}\text { Homogeneização dos mercados de } \\
\text { trabalho }\end{array}$ & Diversificação \\
\hline \multirow{9}{*}{ Estado } & Regulamentação & $\begin{array}{l}\text { Desregulamentação } \\
\text { Rerregulamentação }\end{array}$ \\
\hline & Rigidez & Flexibilidade \\
\hline & Do bem-estar social & $\begin{array}{l}\text { Privatização das necessidades } \\
\text { coletivas e da seguridade social }\end{array}$ \\
\hline & $\begin{array}{l}\text { Estabilidade internacional através de } \\
\text { acordos multilaterais }\end{array}$ & $\begin{array}{l}\text { Desestabilização internacional } \\
\text { Crescentes tensões geopolíticas }\end{array}$ \\
\hline & Centralização & Descentralização \\
\hline & Subsidiador & Empreendedor \\
\hline & Intervenção indireta em mercados & Direta \\
\hline & $\begin{array}{l}\text { Pesquisa e desenvolvimento } \\
\text { financiados pelas empresas }\end{array}$ & Financiador de P\&D \\
\hline & Inovação liderada pela indústria & Líder de inovação \\
\hline \multirow[t]{2}{*}{ Ideologia } & Sociedade do consumo & Consumo individualizado \\
\hline & Modernismo & Pós-modernismo \\
\hline
\end{tabular}

Fonte: A partir de Swyngedouw apud Harvey (2014). 
Esse período é marcado ainda pela intensificação das taxas de crescimento de inovação comercial, tecnológica e organizacional, além da diminuição espaço-tempo e estreitamento da difusão das tomadas de decisões ocasionadas pelos avanços nas comunicações e diminuição dos custos de transportes. Nas relações trabalhistas a acumulação flexível enfraqueceu sindicatos gerando instabilidade e insegurança crescentes nos empregos (HARVEY, 2014, p. 174).

O Quadro 2.1 mostra as mudanças na estrutura organizacional das empresas, especialmente o sistema de just in time, ou seja, a matéria-prima e os estoques intermediários necessários ao processo produtivo são supridos no tempo e na quantidade exata, sem estoque e; a auto-ativação da produção baseada numa força de trabalho multifuncional e flexível (CATTANI, 1996, p.158).

Essa flexibilização de custos e ao mesmo tempo a intensificação da competição e dos riscos negociais levaram as empresas à terceirização, assim as subcontratadas passaram a ter fundamental importância na acumulação flexível, uma vez que o capital de giro foi reduzido e parte do capital produtivo das grandes empresas desviado para o mercado financeiro em busca da acumulação. Com as terceirizações surgem as interferências territoriais, pois a integração das empresas com seus fornecedores exigiria uma malha urbana de transportes e de comunicações avançadas, além da proximidade das empresas envolvidas na cadeia produtiva. Este cenário relativizou a integração vertical e horizontal da produção fordista.

De acordo com Harvey (2014, p.140), a acumulação flexível trouxe rápidas mudanças nos padrões do desenvolvimento desigual fordista nos setores de produção fazendo grande parte dos trabalhadores atuarem no setor de serviços, o surgimento de empresas inovadoras. O Quadro 2.1 mostra que essas mudanças trouxeram a concentração de produtos e serviços em economias de aglomeração, que de acordo com Benko (1996, p.144), são as aglomerações urbanas intensificadas pelas novas relações entre as empresas, ou seja, uma rede de firmas especializadas ligadas por relações de subcontratação ou de parceria, características da acumulação flexível.

Quanto ao Estado, conforme observado no Quadro 2.1 interessa à acumulação flexível aquele que não interfere na economia, neoliberal. Assim, desregulamentação, liberalização, privatização, inflação baixa, estabilidade cambial e responsabilidade fiscal são as principais referências estatais para as empresas se instalarem em determinados territórios. 
Importante mencionar ainda, as mudanças no regime de acumulação flexível quanto aos investimentos em inovações. Neste é o Estado que financia a produção de pesquisa e desenvolvimento sendo também o líder inovador ${ }^{8}$.

A acumulação flexível é a expressão máxima do capitalismo atual, cuja capacidade produtiva apoia-se fundamentalmente no desenvolvimento do setor terciário avançado, dependente de inovação ${ }^{9}$ e de recursos humanos altamente qualificados. Com ênfase na inovação, nesse sistema de acumulação, os meios inovadores seriam postos avançados para os usos do território.

Para Aydalot (1986, p. 03) a inovação possui ligação com o território ${ }^{10}$. Esta ligação ocorre no meio inovador ${ }^{11}$, que se constitui em um conjunto territorializado marcado pela interação dos agentes envolvidos. No meio inovador, o passado do território, os comportamentos dos agentes envolvidos, a sua organização são componentes essenciais. Retomando as assertivas de $\operatorname{Santos}^{12}$, o uso do território se baseia no passado que é uma condição dada pelo território para a sua realização e o futuro, pois os eventos modificam a realidade presente, contribuindo para criar condições para novos eventos. Portanto, o território usado encontra-se em permanente transformação segundo o sentido e a essência dos eventos que abarca.

O meio inovador é uma organização territorial onde os processos de inovação surgem. Maillat (2002, p. 14) afirma que o meio inovador é capaz de se abrir à diversidade do território, seus usos, surgindo estruturas produtivas capazes de gerar inovação, como os parques tecnológicos.

\footnotetext{
${ }^{8}$ Essa acepção de Estado inovador é importante nesta análise. No Capítulo 06 vamos mostrar que o Estado é o empreendedor do PTCD. Por isso, está destacada a sua importância no Quadro 2.1.

9 A inovação aqui compreendida como a introdução de produtos ou processos tecnologicamente novos e melhorias significativas em produtos e processos existentes (OCDE, 2015, p.35).

${ }^{10}$ Aydalot (1986) propõe um visão de espaço ativo, em que as inovações ocorrem no território.

${ }_{11}$ Nos interessa essa discussão para o entendimento que esse meio inovador pode ser um parque tecnológico como se verá adiante.

${ }^{12}$ Ver discussão sobre o território usado no tópico 2.1.
} 


\subsection{As discussões sobre os parques tecnológicos e seus desdobramentos no território usado}

Ainda mantendo os complexos industriais característicos do período fordista, a acumulação flexível tem como uma das suas principais expressões os parques tecnológicos. Considerando que os parques tecnológicos são meios inovadores no regime de acumulação flexível e também apropriações dos usos no território serão aqui definidos como agrupamentos de empresas com base na Ciência e Tecnologia (C\&T) e em Pesquisa e Desenvolvimento (P\&D).

A Organização para Cooperação Econômica e Desenvolvimento - OCDE define Ciência e Tecnologia (C\&T) como o conjunto de conhecimentos científicos ou empíricos capazes de contribuir para melhoria nos processos produtivos de bens ou serviços. A Pesquisa e Desenvolvimento (P\&D), compreendem o trabalho criativo, realizado em bases sistemáticas, com a finalidade de ampliar o estoque de conhecimento e o uso deste na busca de novas aplicações (OCDE, 2015, p. 4).

Os parques tecnológicos são empreendimentos que visam estimular a transferência de tecnologia para as micro e pequenas empresas (NOCE, 2002; VIEIRA; HAUSER, 2002). De acordo com Spolidoro (1997, p. 22) são iniciativas com base numa área física destinadas a receber empresas de Ciência e Tecnologia - C\&T e promover a interação com instituições de ensino e pesquisa.

Os parques tecnológicos são empreendimentos imobiliários que abrigam empresas inovadoras e intensivas em conhecimento (NOCE, 2002). Sáenz; García Capote (2002) afirmam que os parques tecnológicos são empreendimentos de natureza híbrida, pois objetivam tanto o desenvolvimento científico, tecnológico, econômico quanto o desenvolvimento imobiliário.

A partir da difusão dos parques tecnológicos e, notadamente, com a constatação de que algumas dessas experiências contribuíram para alavancar economias locais, surgiu uma literatura que buscou identificar as causas de sucesso e insucesso dessas iniciativas. Teóricos como Harvey (1982) e Smith (1988) afirmam que existe um desenvolvimento $^{13}$ desigual pautado em duas perspectivas simultâneas e contraditórias, ao mesmo tempo que existe uma alta mobilidade do capital no território, esse procura fixar-se em determinados lugares para completar o processo de acumulação flexível.

\footnotetext{
$13 \mathrm{O}$ desenvolvimento aqui proposto, não somente o econômico, mas o socioespacial.
} 
É justamente sob essas perspectivas que os parques tecnológicos podem ou não obter sucesso, vez que propiciam determinadas infraestruturas atraentes às empresas para responder às condições econômicas e consigam encontrar os lugares que ofereçam maior possibilidade de lucro. Para Vargas; Jatobá; Cidade (2012) isso pode significar às empresas migrar dos centros de produção já consolidados a outros mais atraentes, com melhores condições de produção.

Os parques tecnológicos têm sido objeto de inúmeros debates. Os defensores dos parques tecnológicos atribuem a esse modelo o poder de gerar efeitos de difusão sobre as áreas vizinhas. Aproveitando o potencial dos centros acadêmicos preexistentes, ao lado das iniciativas políticas e empresariais para a implantação de um polo de crescimento, surgem parques tecnológicos baseados no modelo de F. Perroux ${ }^{14}$, em que as inovações seriam a base das indústrias motrizes ${ }^{15}$.

Perroux (1977) afirma que o polo ${ }^{16}$ é o centro econômico de um país e o seu crescimento se faz sentir sobre o espaço que o cerca, uma vez que ele cria fluxos espaciais em direção aos centros. Perroux cita como exemplo as experiências francesas ${ }^{17}$ que possuem vários centros, interligados o que permite a difusão em toda a área vizinha.

Para Figueiredo (1993, p. 91), os parques tecnológicos representam o resultado do esforço corporativo entre instituições de ensino e pesquisa com apoio governamental voltado para o desenvolvimento das inovações. Santos; Vermulm (1997, p.5), consideram os parques como formas de atuação para o desenvolvimento, sendo empreendimentos que envolvem grandes áreas no qual coexistem centros de pesquisas, universidades, infraestrutura habitacional e difusão cultural no território.

Também defensores dos parques tecnológicos Oh; Masser (1995, p. 296) afirmam que estes se constituem como parte de estratégias de desenvolvimento, pois em vários países, a política industrial é a de oferecer áreas e ambientes às indústrias de inovação, recursos que se tornaram escassos em centros urbanos. Para eles, um dos objetivos dos parques tecnológicos é a produção de inovações em áreas menos desenvolvidas, através da implementação descentralizada de infraestrutura física, científica e institucional, com base nos usos do território em que se instalam.

\footnotetext{
${ }^{14} \mathrm{O}$ modelo de Perroux pertence a uma etapa anterior do Capitalismo, todavia suas considerações estão ainda em sintonia com a dinâmica de acumulação atual.

15 As indústrias motrizes seriam as empresas âncoras no caso dos parques tecnológicos e capazes de exercem atração de outras indústrias de inovação.

${ }^{16}$ Aqui considerado na forma de parque tecnológico.

${ }^{17}$ Serão apresentadas algumas dessas experiências no próximo tópico.
} 
Para Medeiros (1997, p. 60), um dos indicadores dos resultados proporcionados pela implantação dos parques tecnológicos é a alteração da dinâmica urbana de uma cidade. Concordando com essa assertiva, Gouveia (1991) ressalta que os parques tecnológicos funcionam como um instrumento de ordenamento econômico, científico-tecnológico e territorial, pois propiciam a concentração de recursos que beneficiam não só o ambiente tecnológico e empresarial local, como favorecem a atratividade para eventuais investidores.

Todos esses defensores convergem para um mesmo argumento: os parques tecnológicos constituem instrumentos eficazes de desenvolvimento. Tavares (1993, p. 281) sintetiza o presente argumento: o parque tecnológico é um instrumento eficaz de desenvolvimento, isso porque ele pode ser adaptado a uma ampla gama de territórios. Os parques concorrem para diminuir as disparidades no território, graças ao seu maior efeito difusor, beneficiam o meio urbano em que se localizam e, geralmente se conectam com centros tecnológicos situados em outras áreas.

Por outro lado, os críticos dos parques tecnológicos consideram que os seus efeitos com potencial de difusão e atuação seletiva dão-se apenas sobre áreas específicas. Storper (1990, p.143), um dos principais críticos afirma que o sistema de acumulação flexível cria parques tecnológicos de crescimento altamente concentrados, em que alguns locais são beneficiados, enquanto outros são deixados para trás. Quevtt (1988, p.30) completa essa afirmação: a emergência de parques tecnológicos não responde a uma lógica de desenvolvimento, mas antes a uma lógica de concentração de fatores de produção de ordem intelectual.

Confirmando tais assertivas em relação à primazia de acumulação dos parques tecnológicos Storper (1988) questiona se os parques tecnológicos podem ser um instrumento de desenvolvimento. Storper afirma que pelo seu caráter concentrador, o parque não é um instrumento eficaz de diminuição de desigualdade, pois suas estruturas estão associadas ao caráter hegemônico de controle dos avanços tecnológicos por determinados grupos e instituições. Massey et al (1992) afirma que os parques tecnológicos são formas urbanas com grande prestígio imobiliário com poucas sinergias entre os agentes envolvidos ${ }^{18}$. Também não existe a preocupação em desenvolver a área em que se encontram, apenas gerar condições para a produção.

\footnotetext{
18 Os agentes envolvidos serão denominados mais adiante no Capítulo 06, como sujeitos/atores, agentes diretamente intencionados nos processos de inovação.
} 
Para outros autores como Kumar (1997) e Faberon (1990), denominados críticos da acumulação flexível, os parques tecnológicos representam a materialização do momento hegemônico globalizante. Por meio destes, a acumulação flexível produz formas de concentrar e desconcentrar o processo sistemático de inovações.

Segundo Kumar (1997), os parques tecnológicos são formas espaciais que rompem com as relações fixas e rígidas das relações capitalistas organizadas e representam a materialidade do capitalismo desorganizado ${ }^{19}$. Assim, os parques tecnológicos reproduzem as desigualdades espaciais e, ao mesmo tempo produzem tecnologias que rompem as estruturas tradicionais.

Faberon (1990) afirma que os parques tecnológicos destacam-se como uma das formas contemporâneas do desigual desenvolvimento que continuam a diferenciar e hierarquizar o espaço. Informa o autor, que muitos estudiosos dedicados aos parques tecnológicos têm mostrado que o rumo estava bem definido, ou seja, tornar o parque o lugar de convergências de forças para renovar o processo de acumulação.

Castells (2001) numa perspectiva crítica em relação aos parques tecnológicos afirma que estes representam uma fantasia da modernidade, pois os centros metropolitanos mundiais continuam a acumular fatores indutores de inovação e a gerar a sinergia na indústria e serviços avançados. Os parques tecnológicos utilizam os meios antigos e novos com base em sua estrutura e dinâmica interna de dispersão e mais tarde atraem empresas e investimentos. As suas contradições tornam-se maiores quando competem e cooperam em diferentes níveis (local/regional) ao mesmo tempo, criando uma rede de interações que os associam a uma estrutura industrial comum que supera sua descontinuidade no território.

Seguindo nessa mesma linha crítica em relação aos parques tecnológicos, debates recentes de autores como Borrás; Lundvall (2003), Malerba (2005), Vedovello; Judice; Maculan (2006), Tavares (2012) apontam algumas fragilidades desses enquanto instrumentos de políticas de desenvolvimento. Entre essas limitações estão: o risco de pulverização dos recursos; o aumento dos custos de capacitação por conta do turnover $^{20}$; a tendência de excessiva especialização nas áreas em se encontram; o rápido crescimento dos preços dos aluguéis e da infraestrutura locais; o longo prazo de desenvolvimento e

19 A teoria do capitalismo organizado e desorganizado foi discutida por Lash e Urry (1987) e mostra que no capitalismo organizado existe grande concentração e a especialização (cidades industriais) das atividades produtivas no território e num capitalismo desorganizado ocorre o declínio destas cidades industriais com movimentos de desconcentração e dispersão das atividades produtivas criando novas áreas de desenvolvimento, principalmente voltadas ao setor de serviços.

${ }^{20}$ Nesse contexto significa rotatividade dos trabalhadores. 
maturação; o elevado custo de sua implantação e; a sua limitada capacidade de geração de empregos.

Com base nas considerações dos autores anteriormente mencionados, os parques tecnológicos são expressões espaciais no regime de acumulação flexível e também apropriações dos usos no território. Este trabalho pressupõe, em uma fase desenvolvimentista, os então chamados complexos industriais foram os instrumentos de desenvolvimento, reflexos de políticas governamentais. Assim, a implantação teria sido "de cima para baixo".

Em uma fase seguinte, com tendências neoliberais, os parques tecnológicos são os instrumentos de desenvolvimento endógeno, resultantes das políticas públicas formuladas pelos vários agentes envolvidos de um dado lugar. Assim, haveria uma perspectiva de implantação "de baixo para cima". Em uma fase neodesenvolvimentista, em países em desenvolvimento como o Brasil, os parques tecnológicos, seriam instrumentos de desenvolvimento endógeno e representariam uma alternativa de desenvolvimento. Dessa forma, a sua implantação refletiria uma perspectiva combinada: "de cima para baixo e de baixo para cima".

Benko (1996), afirma que a globalização da economia metropolitana caminha de par com a implementação de parques tecnológicos que aparece ao mesmo tempo como um efeito e como uma causa do desenvolvimento. Neste contexto, os parques tecnológicos surgem em territórios de funções superiores que são como um espaço de comunicação para a integração de conhecimento e produção cultural de uma mão de obra altamente qualificada na acumulação flexível.

Além dos aspectos econômicos e sociais envolvidos na temática dos parques tecnológicos, existem os aspectos territoriais. A inserção destes interfere na organização espacial das cidades. Em uma fase de expansão urbana em que tendências de adensamento convivem com a fragmentação do tecido ocupado, os parques tecnológicos têm participado de tal forma a criar ou reorganizar centros de produção que interessam ao capital. Assim, os parques tecnológicos são utilizados para promover o desenvolvimento econômico, mas poder ser utilizados como políticas regionais/locais. As suas características e requisitos para a sua implementação são fundamentais para o entendimento das primeiras experiências mundiais com estes meios inovadores como se verá adiante. 
Capítulo 3

\section{EXPERIÊNCIAS MUNDIAIS COM PARQUES TECNOLÓGICOS}

“(...) para onde a reinvenção cultural da base técnico-científica tende a levar a sociedade, para nova repetição padronizante ou para o livre curso da diversidade? Se não se põe em dúvida a necessidade da superação da velha cultura técnico-científica (...) o capitalismo não é capaz de contemplar uma cultura da diferença com a liberdade humana que isso implica."

(MOREIRA, Ruy. O círculo e a espiral. Rio de Janeiro: Obra Aberta, 1993, p.4) 


\subsection{Parques tecnológicos: definições e critérios}

De acordo com a International Association of Science Parks (IASP, 2014) o parque tecnológico ${ }^{21}$ é uma organização mantida por especialistas em tecnologia, na qual o objetivo é incrementar a renda local, promovendo a inovação, a cooperação e a competitividade das empresas e das instituições geradoras de conhecimento. É por meio do parque tecnológico que ocorre o fluxo de conhecimento e tecnologia entre as universidades, as instituições de pesquisa, as empresas.

Os parques tecnológicos resultam do esforço corporativo integrado entre instituições de ensino e pesquisa voltado para o desenvolvimento de inovações nas áreas de informática, eletrônica, mecânica de precisão, novos materiais, biotecnologia, química fina, aeroespacial e telecomunicações. Para Harvey (1992) os parques tecnológicos visam a renovação da estrutura industrial anterior numa espécie de reparo espacial ou desenvolvimento do setor de serviços avançados no território.

Os parques tecnológicos podem se apresentar na forma de três espécies segundo Medeiros et al (1993, p. 91): 1) parque com estrutura informal: inexiste uma estrutura organizacional formal, (empresas e instituições de E\&P dispersas pela cidade); mesmo assim, projetos de inovação são definidos pelos parceiros; 2) parques com estrutura formal: empresas e instituições de ensino e pesquisa dispersas pela cidade, mas existe uma entidade coordenadora (fundação ou sociedade civil) cujas missões são agregar esforços e coordenar as ações dos parceiros envolvidos no projeto de inovação tecnológica; 3) parque tecnológico (science park) ${ }^{22}$ : além da estrutura organizacional formal, as empresas estão reunidas próximas a instituições de ensino e pesquisa, ou dentro do campus da universidade; os professores universitários estão frequentemente nos parques e os equipamentos e laboratórios das universidades estão disponíveis para uso das empresas (FIGUEIREDO, 1993, p.91).

Segundo Medeiros e Atas (1997, p.57), os parques tecnológicos são iniciativas concebidas para facilitar a transferência de inovações, desenvolvendo esforços voltados a

\footnotetext{
${ }^{21}$ O conceito de parque tecnológico apresenta inúmeras acepções. Autores como Benko (1991, 1999); Droulers (1993); Faberon (1990); Medeiros (1992) o denominam como Technopôle, Tecnopolo ou Polo Tecnológico. Outros autores como Spolidoro (1997); Castells \& Hall (1994) como Technopole. E ainda outros que os definem como Science Parks (Massey, Quintas \& Wield, 1992). Adotarei nesta Tese este último que é o utilizado em sua tradução literal - parques tecnológicos pela ANPROTEC, IBGE, Medeiros \& Atas (1997); Lima (1993); Stumpfl (1995); Lencioni (2007).

${ }^{22} \mathrm{O}$ objeto de estudo desta Tese, o PTCD é espécie de parque tecnológico como se verá adiante no Capítulo 06.
} 
difusão das descobertas científicas e pesquisas dos laboratórios para o mercado, transformando o conhecimento em produtos, processos e serviços avançados. Esse processo de inovação na acumulação flexível se refere a uma primeira comercialização de uma ideia ou projeto (ARBIX, 2010).

Entre os requisitos para a implantação de parques tecnológicos estão a existência de universidade e outras instituições de ensino e pesquisa, voltados à transferência de inovações; a disponibilidade de estruturas de financiamentos apropriados para as empresas; a existência de projetos conjuntos entre empresas e outros parceiros; a habilidade de captar demandas das empresas, sempre identificando o potencial e os desdobramentos das novas tecnologias e; a capacidade de complementar as ações dos diversos parceiros e integrá-los numa rede apropriada (MEDEIROS; ATAS, 1997, p.65).

Os recursos disponíveis às empresas inovadoras nos parques tecnológicos, além do suporte físico e gerencial são: o acesso a consultores especializados e estudantes estagiários; o uso de infraestrutura, equipamentos e facilidades de laboratório e bibliotecas, computadores e serviços de telecomunicações; a educação (formação) continuada para os empregados das empresas; a identificação de oportunidades de parceria entre as empresas e destas com as instituições de ensino e pesquisa e outras entidades públicas e privadas (STUMPFL, 1995, p. 89).

De acordo com Benko (1996, p.153), os parques são meios inovadores com características diferenciadas utilizados por cidades cujas estratégias de desenvolvimento socioeconômico se apoiam na valorização de seu potencial universitário e de pesquisa. Lima (1993, p. 285) afirma que quanto as suas características, os parques tecnológicos se distinguem das demais formas produtivas pelos seguintes aspectos: a) ligam-se às inovações tecnológicas não só resultantes de suas pesquisas como também provenientes de outros centros; b) estreitas vinculações das empresas inovadoras com as instituições de pesquisa ou de transferência de tecnologia; c) apoio ao capital de risco, seja de agências de fomento do governo, seja do setor privado, para criação e difusão de empresas de base tecnológica (EBTs) e; d) um conjunto de externalidades locais e regionais que possibilitem serviços adequados à dinâmica das trocas, tais como sistemas de telecomunicações, instalações para empresas nascentes, agências governamentais dos vários níveis de governo, serviço de apoio, firmas comerciais.

Os parques tecnológicos são formados por projetos sintonizados com a dinâmica de acumulação flexível, em programas estruturados (e estruturantes) que fortalecem a articulação entre empresas - tanto as intensivas em tecnologia como as dos 
setores tradicionais da economia. A implementação de parques tecnológicos tem como objetivos: a) possibilitar o aumento do relacionamento entre as empresas com as entidades governamentais, instituições de ensino e pesquisa e; b) transformar o território para o desenvolvimento socioeconômico e urbano (MEDEIROS; ATAS, 1997, p.64).

Os parques tecnológicos facilitam o processo de inovação e a dinâmica territorial para alcançar os seguintes resultados: orientar a gestão do processo de inovação; facilitar a transferência de inovação interna e externa (troca de informações), a definição de linhas de fomento-financiamento apropriadas, a criação e consolidação de micro e pequenas empresas; aumentar a parceria empresa-academia-governo; oferecer infraestrutura adequada às empresas; estimular o aumento da qualidade e competitividade; apoiar o desenvolvimento de áreas de inovação prioritárias expostas no início deste capítulo e; alterar a dinâmica territorial ${ }^{23}$ (MEDEIROS; ATAS, 1997, p. 60).

O Quadro 3.1 abaixo mostra as principais características dos parques tecnológicos enfatizando a importância da localização, da infraestrutura, gestão e a interação com a comunidade local. Coordenadas de forma adequada a implementação de parques tecnológicos pode possibilitar a transformação ou reorganização produtiva nos territórios no qual são inseridos.

Quadro 3.1 Características dos Parques Tecnológicos

\begin{tabular}{|c|c|}
\hline Características & Parque tecnológico \\
\hline Função & $\begin{array}{l}\text { Constituir um ambiente de inovação para promover a criação, a } \\
\text { instalação e desenvolvimento de empresas intensivas em } \\
\text { conhecimento e a conquista de competitividade. }\end{array}$ \\
\hline Estratégia & $\begin{array}{l}\text { Redução de custos e promover intensa sinergia das empresas, } \\
\text { instituições de ensino, Governo e agências de desenvolvimento de } \\
\text { modo que o conjunto tenha elevada capacidade de inovação. }\end{array}$ \\
\hline $\begin{array}{l}\text { Prédios, terrenos } \\
\text { e infraestrutura } \\
\text { na base física }\end{array}$ & $\begin{array}{l}\text { Prédios e terrenos para vender, alugar ou ceder sob condições } \\
\text { especiais; infraestrutura avançada tecnicamente; configuração } \\
\text { ambiental, urbanística e arquitetônica. }\end{array}$ \\
\hline Gestão & $\begin{array}{l}\text { Em regra, a administração é efetuada por uma entidade gestora } \\
\text { (Governança) sob a forma de uma parceria público-privada. }\end{array}$ \\
\hline $\begin{array}{l}\text { Formas de cessão } \\
\text { das terras e prédios }\end{array}$ & $\begin{array}{l}\text { Em geral, as terras e os prédios não são vendidos, mas } \\
\text { administrados pela Governança, que os aluga sob diversos } \\
\text { formatos. }\end{array}$ \\
\hline Localização & $\begin{array}{l}\text { Áreas nobres, em geral adjacentes ou próximas de universidades e } \\
\text { centros de P\&D. }\end{array}$ \\
\hline $\begin{array}{l}\text { Razões para a ação } \\
\text { ou apoio do Governo } \\
\text { à iniciativa }\end{array}$ & $\begin{array}{l}\text { Contribuir para a infraestrutura humana, física e organizacional } \\
\text { que um território deve dispor para que as suas empresas sejam } \\
\text { competitivas. }\end{array}$ \\
\hline
\end{tabular}

${ }^{23}$ Este nos interessa diretamente pois mostra a interferência dos parques tecnológicos no território usado. 


\begin{tabular}{c|l}
\hline Meio ambiente & Obrigatoriedade no cumprimento das legislações ambientais. \\
\hline Uso da infraestrutura local & $\begin{array}{l}\text { Aproveitamento da infraestrutura local como as redes de } \\
\text { abastecimento, elétrica }{ }^{24} \text { e de transportes. }\end{array}$ \\
\hline $\begin{array}{c}\text { Interação com a } \\
\text { comunidade }\end{array}$ & Busca de interação com a comunidade local. \\
\hline
\end{tabular}

Fonte: adaptado de Spolidoro, 2006.

A implantação de parques tecnológicos compreende segundo Medeiros (1997) ações de natureza experimental, não existindo nenhum modelo preexistente nem regras previamente definidas, tratando-se de um programa concebido para favorecer a inovação a partir da articulação entre ensino, pesquisa e empresas. Hardt (1997) define as cinco dimensões a serem consideradas em projetos de parques tecnológicos: a) Espacial: reordenamento territorial; b) Tecnológica: desenvolvimento e transferência de tecnologia; c) Econômica: criação de emprego; d) Sociológica: adoção de novas posturas relativas à organização do trabalho e; e) Política: reforço das interações entre os agentes envolvidos.

Rebello (1997, p.06) afirma que devem ser pensados no projeto do parque tecnológico, módulos que prevejam existência de: um ágora que procure recriar o ambiente da cidade clássica, representada por uma praça central cercada de restaurantes, cafés, lojas de refeições rápidas, hotéis, lojas completas, oficinas de manutenção e serviços diversos; um centro de convenções de uso múltiplo; estacionamento em número adequado e equidistante da ágora; um terminal multimodal de transporte público, com ônibus, metrô, o nó de ciclovias da área e imediações, heliporto, trem leve de circulação interna.

A partir da existência desses módulos, Rebello (1997, p. 07) afirma que deverá ocorrer uma distribuição das instituições de ensino e pesquisa, órgãos governamentais relacionados à ciência, tecnologia, indústria e comércio, entidade gestora do Parque e das empresas na seguinte distribuição demonstrada na Figura 3.1: uma primeira camada, composta pelos centros empresariais voltados para atendimento de micro e pequenas empresas; uma segunda camada para situar empresas e instituições de pesquisa de porte médio e; um terceira camada voltada para empresas e instituições de ensino e pesquisa de grande porte.

\footnotetext{
${ }^{24}$ No caso do PTCD, foi construída uma subestação de energia para atender a demanda específica do parque tecnológico.
}

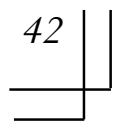




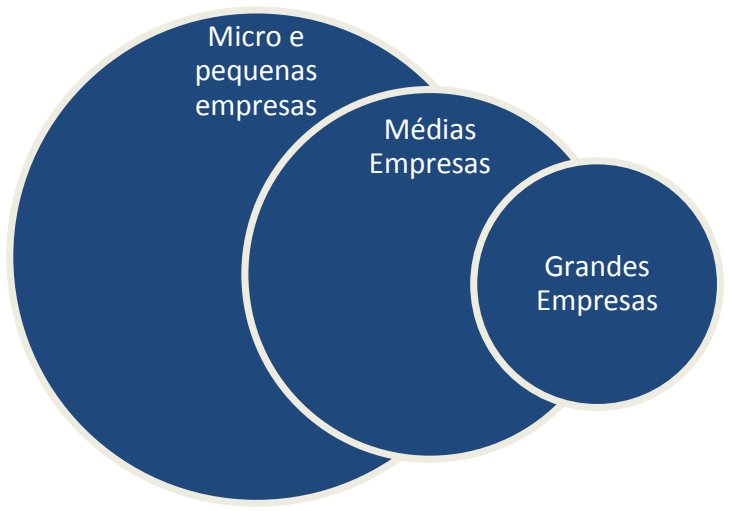

Figura 3.1 Distribuição dos módulos em projetos de parques tecnológicos

Mostra a distribuição das empresas em camadas nos parques tecnológicos, sendo a maior delas destinada a centros empresariais para as micro e pequenas empresas.

Fonte: Elaborado pelo autor.

A decisão sobre a alocação de parques tecnológicos obedece a dinâmica da acumulação flexível. É preciso apresentar características locais atraentes ao capital estrangeiro. O Investimento Direto Estrangeiro (IDE) é fundamental para a determinação dos fatores influenciadores no processo de localização espacial das empresas inovadoras.

De acordo com Mattos; Cassuce; Campos (2007) os IDEs estão condicionados a fatores relativos à atividade desenvolvida pelas empresas, as características e os aspectos econômicos dos países envolvidos, podendo ser aplicados de acordo com: as vantagens compensatórias de acesso ao capital e as diferenças de captação; a integração dos mercados que minimizam os custos das transações ${ }^{25}$ e as vantagens locacionais.

Para Dunning (1994), as empresas estrangeiras apresentam vantagens em relação às concorrentes locais por possuírem ativos tangíveis e intangíveis de forma privilegiada, portanto, a decisão da empresa em produzir em determinado país se dará como resultado das vantagens locacionais deste. E ainda, produtos que requerem a aplicação de inovações são produzidos nos países avançados. A implantação de parques tecnológicos em países avançados surgiu neste contexto.

${ }^{25}$ Considerando que as empresas multinacionais detêm os direitos de propriedade de marketing, design, patentes e marcas. 


\subsection{Primeiras experiências inovadoras no mundo}

Os primeiros parques tecnológicos surgiram num contexto mundial marcado pelo crescimento da hegemonia norte-americana, a emergência da União Europeia e o bloco asiático. Com a crise do petróleo houve um aumento dos preços e uma instabilidade financeira. Neste quadro, tornou-se necessário repensar o regime de acumulação. Assim, surgem na segunda metade do século $\mathrm{XX}$, as empresas multinacionais estabelecendo suas unidades produtivas em diferentes territórios, principalmente em países em desenvolvimento.

Estas empresas multinacionais passaram a produzir nos países em desenvolvimento a custos reduzidos com mão de obra, matéria-prima local e infraestrutura exportando os produtos a preços competitivos para os países avançados. Harvey afirma que os anos de 1970 e 1980 do século passado foram uma fase de transição para o regime de acumulação flexível com efeitos sobre a organização industrial. $\mathrm{O}$ advento das inovações trouxe novas formas produtivas, além das empresas multinacionais, incorporando empresas específicas de produção de inovações. As formas resultantes no território foram os parques tecnológicos.

Em suas primeiras manifestações, os parques tecnológicos estavam ligados a iniciativas empresariais que adotaram inovações para o aumento da competitividade. Apoiados em investimentos estrangeiros diretos, alguns parques tecnológicos ${ }^{26}$ propiciaram efeitos multiplicadores nas economias regionais em que foram implantados e tornaram-se exemplos de iniciativas promotoras do desenvolvimento.

Estabeleceram-se em alguns dos principais países do mundo como, os Estados Unidos, o Reino Unido, o Japão, a França, a China e a Itália. De acordo com Álvares (2013, p.68) os parques tecnológicos passaram a ter um destaque expressivo no contexto atual de reorganização produtiva ${ }^{27}$ em países avançados e em desenvolvimento.

Segundo a World Aliance for Innovation (WAINOVA, 2014) existem em todo o mundo entre 1.200 e 1.500 parques tecnológicos, sendo que mais de $60 \%$ deles surgiram na década de 1990. Afirma ainda, que existem cerca de aproximadamente 150 parques nos

\footnotetext{
${ }^{26}$ Os parques tecnológicos que surgiram de IDES, serviram como modelo para a implantação de parques tecnológicos em países em desenvolvimento como o Brasil como ser verá adiante.

${ }^{27}$ A reorganização produtiva é aqui entendida como um conjunto de mudanças no sistema fabril voltadas para a acumulação flexível, tendo como um dos resultados a inserção/dispersão e espalhamento das unidades produtivas no território.
} 
Estados Unidos, 70 parques no Reino Unido,111 parques no Japão, 43 na França, 100 parques na China e 32 na Itália.

O Quadro 3.2 abaixo mostra que existem centenas de parques espalhados nestes países, trazendo apenas os que são filiados a WAINOVA. Estas experiências como se pode observar no quadro recebem inúmeras denominações, technopole, polo tecnológico, research park, mas possuem uma característica em comum, a promoção do desenvolvimento econômico.

\section{Quadro 3.2 Parques tecnológicos no mundo}

\begin{tabular}{|l|l|}
\hline País & Parques Tecnológicos \\
\hline & Arizona State University Research Park \\
& Audubon Biomedical Science \& Technology Park \\
& Broad Hollow BioScience Park \\
& Central Florida Research Park \\
& Cornell Agriculture \& Food Technology Park \\
& Cummings Research Park \\
& Delaware Technology Park \\
& First Coast Tech Park, University of N. Florida \\
& Idealliance Piedmont Triad Research Park \\
& Innovation Park Pennsylvania State University \\
& Iowa State University Research Park \\
& Los Alamos Research Park \\
& Milwaukee County Research Park \\
& Mississippi Research \& Technology Park \\
& Missouri Research Park \\
& Evanston Research Park, Northwestern University \\
& Oakdale Research Park, Iowa City \\
& Presbyterian Health Foundation Research Park \\
& Rensselaer Technology Park \\
& Research Park and Enterprise Works at the University of Illinois \\
& Research Triangle Park, North Carolina \\
& River Front Research Park, University of Oregon \\
& Sandia Science \& Technology Park, Albuquerque \\
& Science \& Technology Campus, Columbus \\
& Science \& Technology Park at UNM, Albuquerque \\
& Southern Illinois University Research Park, Carbondale \\
& Techtown Wayne State University \\
& Texas A\&M University Research Park \\
& College Station Texas Research Park, San Antonio \\
& University of North Dakota Technology Park, Grand Forks \\
& University of Texas Health Science Center at Houston \\
& UMBC Research Park and Technology, Baltimore \\
& University City Science Center, Philadelphia \\
& University Corporate Research Park Michigan State University \\
& University of Arizona Science and Technology Park, Tucson \\
& University of Colorado Boulder Research Park, Boulder \\
& University of Nebraska Technology Park, Lincoln \\
& University of New Orleans Research and Technology Park \\
& University of Wisconsin Stout Technology Park \\
\hline &
\end{tabular}




\begin{tabular}{|c|c|}
\hline & $\begin{array}{l}\text { University Park Southern Illinois University, Edwardsville } \\
\text { University Research Park University of Wisconsin-Madison } \\
\text { Virginia Biotechnology Research Park, Richmond } \\
\text { Washington State University Research Park, Pullman }\end{array}$ \\
\hline Reino Unido & $\begin{array}{l}\text { Aberdeen Science \& Technology Park } \\
\text { Ayrshire Innovation Centre } \\
\text { Cheshire Innovation Park } \\
\text { Dundee Medipark } \\
\text { Dundee Technology Park } \\
\text { Edinburgh Technopole } \\
\text { Elvingston Science Centre East Lothian } \\
\text { Heriot-Watt University Research Park } \\
\text { Hillington Park Innovation Glasgow } \\
\text { Lancaster Science Park } \\
\text { Manchester Science Park } \\
\text { MerseyBio, Liverpool } \\
\text { Pentlands Science Park Midlothian } \\
\text { Roslin BioCentre } \\
\text { Scottish Enterprise Technology Park } \\
\text { Stirling University Innovation Park } \\
\text { University of Warwick Science Park } \\
\text { West of Scotland Science Park } \\
\text { Westlakes Science \& Technology Park Cumbria } \\
\text { AURIL Queen's University Belfast } \\
\text { Northern Ireland Science Park Belfast } \\
\text { University of Ulster Science Research Parks } \\
\text { Aston Science Park } \\
\text { Babraham Research Campus } \\
\text { BioCity Nottingham } \\
\text { Brunel Science Park } \\
\text { Cambridge Research Park } \\
\text { Cambridge Science Park } \\
\text { Chesterford Research Park } \\
\text { Chilworth Science Park } \\
\text { Colworth Science Park } \\
\text { Cranfield Technology Park } \\
\text { Granta Park } \\
\text { Kent Science Park } \\
\text { Langstone Technology Park } \\
\text { Loughborough Science Park } \\
\text { Manchester Science Park } \\
\text { Newlands Science Park } \\
\text { Norwich Research Park } \\
\text { Nottingham Science and Technology Park } \\
\text { Oxford Science Park } \\
\text { Sheffield Technology Parks } \\
\text { South Bank Technopark } \\
\text { Sunderland Science Park } \\
\text { Surrey Research Park } \\
\text { Sustainable Growth Park } \\
\text { The London Science Park at Dartford } \\
\text { The North East Technology Park } \\
\text { The Oxford University Begbroke Science Park } \\
\text { The University of Essex Research Park } \\
\text { University of Nottingham Science Park } \\
\text { York Science Park }\end{array}$ \\
\hline
\end{tabular}




\begin{tabular}{|c|c|}
\hline Japão & $\begin{array}{l}\text { Kansai Science City } \\
\text { Kyoto Research Park } \\
\text { Softopia Japan } \\
\text { Ishikawa Science Park } \\
\text { Kurume Research Park } \\
\text { Eniwa Research Business Park }\end{array}$ \\
\hline França & 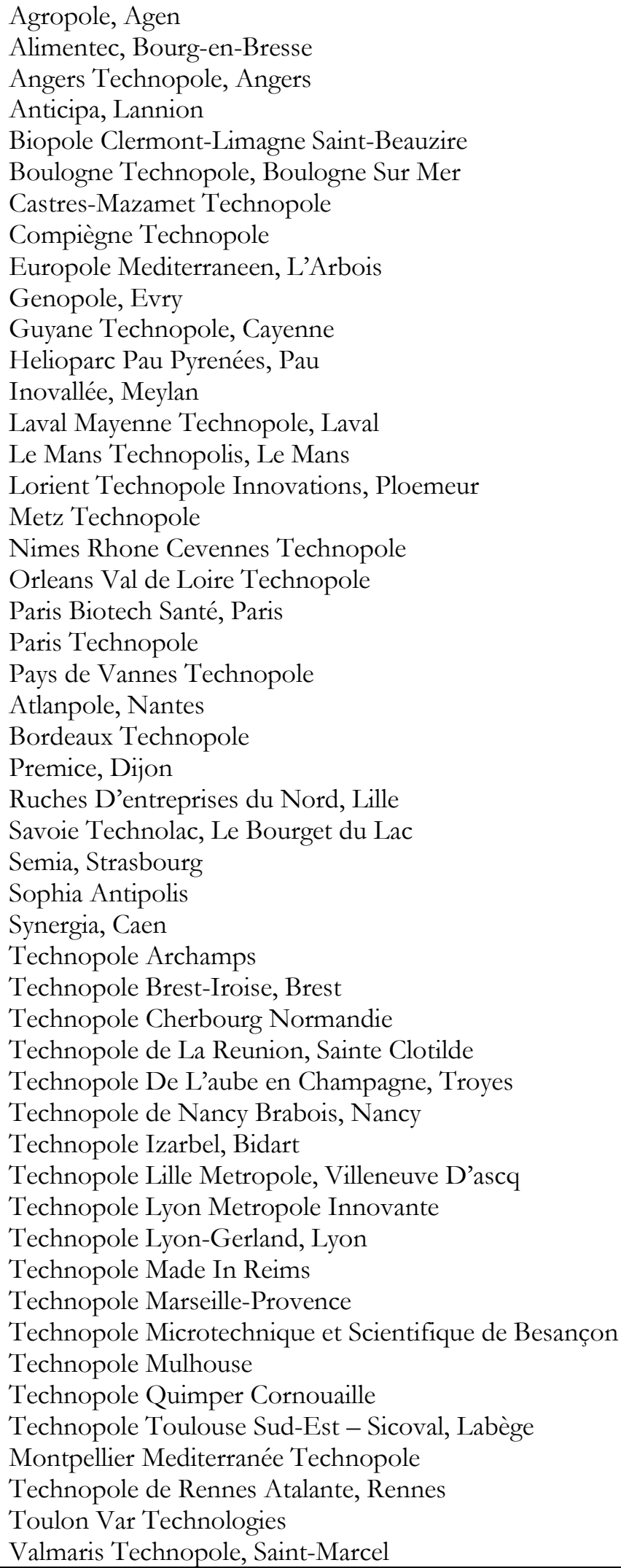 \\
\hline
\end{tabular}




\begin{tabular}{|c|c|}
\hline & Zoopole Developpement, Ploufragan \\
\hline China & $\begin{array}{l}\text { Zhongguancun Haidian Science Park } \\
\text { Beijing Peking University Science Park } \\
\text { Beijing Zhongguancun Life Science Park } \\
\text { Hong Kong Science and Technology Parks } \\
\text { Shanghai Hi-Tech Park } \\
\text { Shanghai Zhangjiang Hi-Tech Park } \\
\text { Shenyang New and High-tech Industrial Develop. Zone } \\
\text { Shenzhen High-Tech Industrial Park } \\
\text { Jinan Hi-Tech Development Zone } \\
\text { Tsinghua University Science Park } \\
\text { Zhengzhou High and New Technology Indust. Develop. Zone } \\
\text { Zhongguancun Science Park }\end{array}$ \\
\hline Itália & $\begin{array}{l}\text { AREA Science Park } \\
\text { Parco Scientifico e Tecnologico della Sardegna } \\
\text { Environment Park Torino } \\
\text { Città della Scienza } \\
\text { Parco Tecnologico Padano } \\
\text { INDUXIA Corporate Park } \\
\text { Virtual Reality and Multimedia Park, Torino } \\
\text { Kilometro Rosso Science Park } \\
\text { Parco Scientifico e Tecnologico della Sicília } \\
\text { Polo Tecnologico di Navacchio } \\
\text { Science Park RAF } \\
\text { Parco Tecnologico Servitec Bergamo } \\
\text { Parco Scientifico e Tecnologico de la Liguria } \\
\text { Parco Scientifico e Tecnologico del Lazio Meridionale } \\
\text { Parco Scientifico e Tecnologico de Venezia } \\
\text { Parco Scientifico e Tecnologico Novus Ortus, Bari. } \\
\text { Parco Scientifico e Tecnologico Galileo } \\
\text { Parco Scientifico e Tecnologico di Napoli e Caserta } \\
\text { Parco Scientifico e Tecnologico de Verona - STAR }\end{array}$ \\
\hline
\end{tabular}

Fonte: A partir de WAINOVA, 2014.

O Quadro 3.2 acima mostra que os parques estão normalmente próximos de universidades ou centros de pesquisa renomados ou em áreas que estavam decadentes ou estagnadas do processo de industrialização. Vejamos o surgimento destes em alguns países avançados.

\section{Estados Unidos}

Os parques tecnológicos tiveram sua origem nos Estados Unidos, a partir dos anos 1970. As experiências do Vale do Silício na Califórnia e da Rodovia 128 em Massachussets tornaram-se os casos paradigmáticos para as demais experiências concretas que seriam adotadas posteriormente em outras regiões americanas e em outros países. $\mathrm{O}$ sucesso dessas duas experiências é notável, pois em sua fase inicial os empreendedores se constituíam basicamente de pequenas empresas, que transformaram as estruturas 
econômicas das regiões nas quais se implantaram, sendo que em cerca de duas décadas tornaram-se centros dinâmicos da economia norte-americana (SANTOS; VERMULM, 1997, p.07).

As principais características desses casos foram a existência nas duas localidades, de universidades e centros de pesquisa de excelência; o papel das pequenas empresas na difusão dos parques tecnológicos nestas localidades; a presença de uma estrutura industrial prévia e; a quarta o papel dos fundos federais e do capital de risco na consolidação dos parques tecnológicos.

Nesse sentido, o governo norte-americano atuou como um provedor de recursos e como importante cliente através dos seus contratos com as empresas destas regiões através dos seus programas militares e espaciais. $\mathrm{O}$ capital de risco, que procura altas taxas de retorno, em empresas com alta capacidade de crescimento, esteve também presente nas duas regiões como fator de sucesso (SANTOS; VERMULM, 1997, p.11).

A presença das pequenas empresas nesses parques gerou oportunidades de inovações nas indústrias de semicondutores e minicomputadores que foram muito numerosas para serem exploradas por poucas empresas. As grandes empresas hesitaram em entrar no mercado de pequenos computadores permitindo assim, um espaço para que as pequenas empresas se aventurassem nesse segmento (SANTOS; VERMULM, 1997, p.07).

De acordo com Tavares (1993, p.276) algumas características são peculiares ao Vale do Silício, tendo contribuído para sua grande importância sistemática e organizacional adotada por várias partes do mundo. A ideia do Silicon Valley surgiu na Universidade de Stanford no intuito de desenvolver a microeletrônica na Califórnia. Para tanto, acreditava-se que era necessário estabelecer fortes relações entre a universidade e as empresas do ramo como a microeletrônica, baseadas na Ciência e na Tecnologia.

Para expandir esta ideia, criou-se o Stanford Industrial Park para conseguir o ingresso de professores de alto nível e a obtenção de fundos para a universidade através de aluguel de terrenos aos capitais privados. A evolução produtiva no parque ocorreu com o advento dos semicondutores e o uso do silício como matéria-prima para a sua fabricação e com a concentração de indústrias militares e aeroespaciais na baía de São Francisco (SANTOS; VERMULM, 1997, p.07).

De acordo com Spolidoro; Audy (2008, p. 46) o Stanford Industrial Park ou Stanford Research Park possuía após quatro anos de funcionamento, em 1974, mais de setenta empresas de base tecnológica em suas instalações, voltadas para o desenvolvimento de pesquisa e desenvolvimento. Com o avanço das atividades na área do parque as 
empresas foram se instalando em outras áreas próximas à Universidade de Stanford, transformando neste processo um imenso parque tecnológico difundido no território urbano.

Assim, consolidou-se um parque tecnológico com atividades de produção e desenvolvimento nas áreas de robótica, de material bélico e aeroespacial, de informática e computação. De acordo com Santos e Vermulm (1997, p.12) a interação entre a universidade de Stanford, diversas instituições de pesquisas civis e militares e empresas como a Intel, Lockheed, IBM, Apple Inc, Boeing, AMD, Xerox, Microsoft, Skype, Start X, Hp e TESLA foi decisiva para o crescimento e consolidação do parque tecnológico. $\mathrm{O}$ exemplo desse parque estendeu-se a vários pontos do território norte-americano. Com base em uma orientação planejada, localizaram-se muitos outros, longe das metrópoles. A Figura 3.2 mostra a vista da entrada da Universidade de Stanford - EUA, considerada uma das mais renomadas instituições de pesquisa em ciência e tecnologia e o prédio moderno de empresa de inovação no Vale do Silício - EUA.

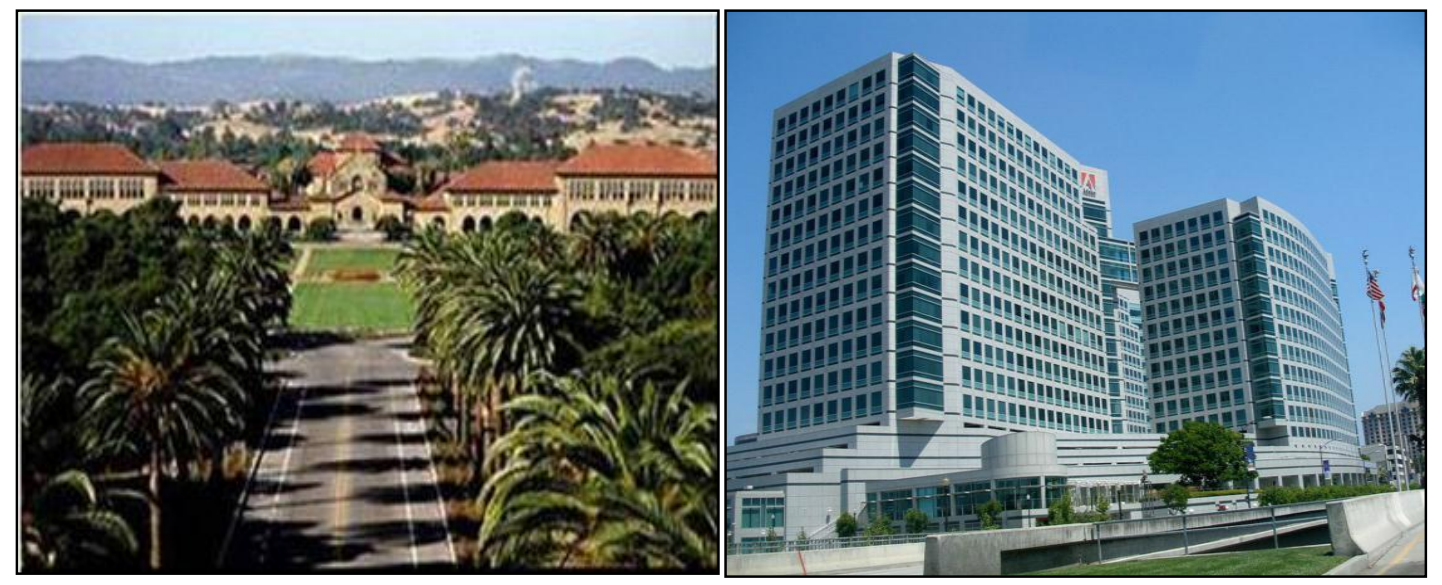

Figura 3.2 Vista da Universidade de Stanford e do Silicon Valley- EUA

Mostra a vista da entrada da Universidade de Stanford - EUA onde surgin a primeira experiência com parques tecnológicos; Fachada de prédio de empresa de inovação no Silicon Valley-EUA.

Fonte: Ribeiro; Spolidoro, 2006.

\section{Reino Unido}

No Reino Unido, os parques tecnológicos foram implementados em meados dos anos de 1970 e se constituíram ao redor das universidades de Cambridge (Inglaterra) e Heriott-Watt (Escócia). A Figura 3.3 mostra a vista aérea do Cambridge Science Park e o 
seu edifício sede. Os dois empreendimentos foram iniciativas de instituições de nível superior e tiveram como motivação o desenvolvimento de Ciência e Tecnologia (C\&T). Somente no início dos anos 1980 é que surgiram outros empreendimentos, criando-se 31 parques entre 1982 e 1985 no Reino Unido. No entanto, para Santos e Vermulm (1997, p.10) estes parques diferenciam-se dos primeiros porque foram criados sob a forma de parcerias, envolvendo normalmente universidades, autoridades locais e bancos.
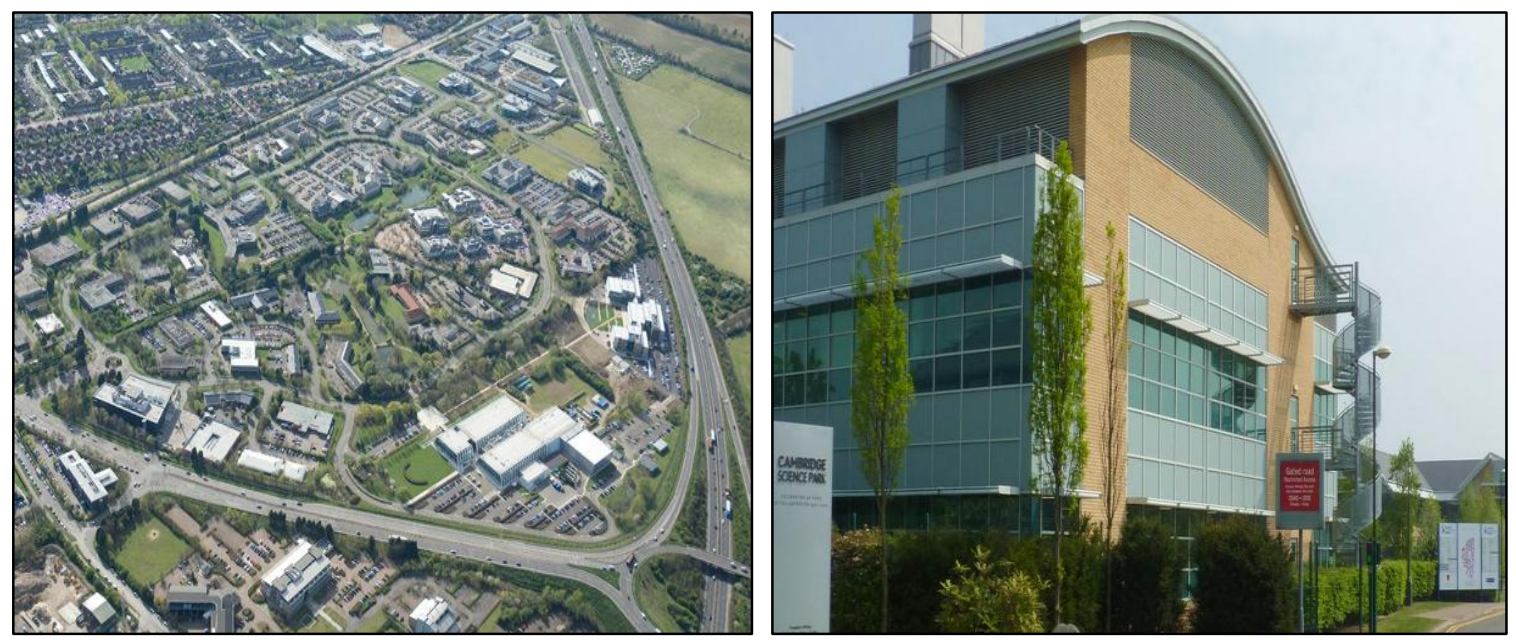

Figura 3.3 Vista aérea do Cambridge Science Park e do edifício sede

Mostra a vista aérea do Cambridge Science Park e as amplas vias de acesso ao parque tecnológico; edifício sede do Cambridge Science Park.

Fonte: Ribeiro; Spolidoro, 2006.

Importante ressaltar que grande parte desses parques foi implantada em áreas economicamente decadentes, para o reerguimento das mesmas, numa tentativa de reorganização produtiva. À medida que os parques tecnológicos tornavam-se facilitadores da acumulação de capital em áreas específicas, passaram a representar opções não apenas para empresas individuais ou consorciadas, mas particularmente para as políticas públicas de desenvolvimento para a redução das desigualdades territoriais, reorganização produtiva das atividades e ao mesmo tempo uma retomada do crescimento de algumas áreas que se encontravam estagnadas. A implementação dos parques tecnológicos nessas áreas exigiu investimentos em grandes obras de infraestrutura e/ou implantação de unidades de produção e inovação, reorganizando o território contíguo.

Em 1987, das 52 universidades britânicas, 35 tinham implementado parques tecnológicos. Ao final de 1991, havia cerca de 39 parques em operação e 18 em fase de 
implementação ou estudo de viabilidade. Estes se constituíram também a partir de iniciativas conjuntas de autoridades locais, agências de desenvolvimento regional, bancos e organizações de caráter privado. Em áreas decadentes, a participação do governo foi elevada, com o apoio por parte deste a instalação do parque e suporte financeiro para estimular inovações e o crescimento de pequenas empresas (SANTOS; VERMULM, 1997, p.10).

A implantação dos parques tecnológicos no Reino Unido levou em consideração os fatores econômicos e de risco, as motivações comportamentais, principalmente as políticas. De acordo com Edwards; Buckley (1998) as empresas de inovação buscam por mercados consumidores com os quais possuam alguma familiaridade, como língua, cultura, história, sociedade, sistema legal (diminui o risco da operação), mercados de alta densidade populacional e espaço geográfico limitado.

Edwards e Buckley (1998) elaboram um modelo teórico estabelecido por meio de pesquisas realizadas no âmbito dos parques tecnológicos no Reino Unido para o entendimento da importância dos fatores locacionais na tomada de decisão das empresas. O modelo teórico estabelece o grau de importância dos fatores locacionais em ordem crescente listados no Quadro 3.3.

O Quadro 3.3 mostra que os fatores locacionais apontados por Gonçalves (2002, p.397) que justificam os IDEs são: a) amplas fontes de matéria-prima; b) reduzidos custos de mão de obra; c) a capacidade de inovação, ou seja, produção de C\&T e; d) capacidade mercadológica, pois os elevados custos de transportes as políticas fiscais de incentivo local podem influenciar no processo de decisão.

Quadro 3.3 Fatores locacionais que influenciam na tomada de decisão das empresas

\begin{tabular}{|c|c|}
\hline Fatores & Respostas \\
\hline $\begin{array}{c}\text { Linguísticos, Culturais e } \\
\text { Históricos }\end{array}$ & $\begin{array}{l}\Uparrow \text { maior facilidade em lidar com pessoas que falam a } \\
\text { mesma língua; } \\
\Uparrow \text { local selecionado pelo fator conforto; } \\
\Uparrow \text { o atrativo era a língua. }\end{array}$ \\
\hline $\begin{array}{l}\text { Institucionais e de } \\
\text { ambiente empresarial }\end{array}$ & $\begin{array}{l}\Uparrow \text { elo histórico e a situação política estável de um } \\
\text { sistema legal similar; } \\
\Uparrow \text { comparado a outros continentes, o mercado em } \\
\text { questão possui maior liberdade; } \\
\Uparrow \text { permite novos concorrentes. }\end{array}$ \\
\hline & $\begin{array}{l}\text { Æ mercado gerenciável devido ao tamanho, } \\
\text { comparado ao tamanho do mercado do país de } \\
\text { origem; }\end{array}$ \\
\hline
\end{tabular}




\begin{tabular}{c|l}
\hline Mercado & $\begin{array}{l}\Uparrow \text { base para expansão para outros países do } \\
\text { continente e outras regiões; } \\
\Uparrow \begin{array}{l}\text { importância do mercado do país, elevada } \\
\text { densidade em um espaço geográfico limitado; }\end{array}\end{array}$ \\
\hline $\begin{array}{c}\text { Disponibilidade e } \\
\text { Custo do Trabalho }\end{array}$ & $\begin{array}{l}\text { disponibilidade de mão de obra considerada } \\
\text { qualificada; } \\
\text { mão de obra barata se comparada ao do } \\
\text { continente; }\end{array}$ \\
\hline $\begin{array}{c}\text { Oportunidade e/ou } \\
\text { Ocasião }\end{array}$ & $\begin{array}{l}\text { a compra da empresa foi resultado de uma posse } \\
\text { em outro país; inicialmente era um bem } \\
\text { intencional. }\end{array}$ \\
\hline
\end{tabular}

Fonte: adaptado de Edwards; Buckley (1998).

Esses fatores locacionais são divididos em duas categorias, segundo Chiesa (1995): aqueles relacionados estritamente com a natureza e o conteúdo das atividades de Pesquisa e Desenvolvimento e; aqueles não relacionados à $\mathrm{P} \& \mathrm{D}$, conforme descrito no Quadro 3.4.

Quadro 3.4 Fatores locacionais relacionados e não relacionados que influenciam na tomada de decisão das empresas

\begin{tabular}{|c|c|c|}
\hline Fatores & Tipo & Características \\
\hline & $\begin{array}{c}\text { Custos de } \\
\text { investimentos }\end{array}$ & $\Rightarrow$ Custo de profissionais, técnicos \\
\hline \multirow{3}{*}{ Relacionados } & Custos de transferência & $\begin{aligned} & \Rightarrow \text { Custos internos de transferência de } \\
& \text { informação e conhecimento entre os } \\
& \text { laboratórios } \\
& \Rightarrow \text { Custos externos para obter informações } \\
& \text { técnicas e de mercado a partir de fontes } \\
& \text { externas }\end{aligned}$ \\
\hline & $\begin{array}{c}\text { Custos } \\
\text { organizacionais }\end{array}$ & $\begin{array}{l}\Rightarrow \text { Construção de uma nova empresa } \\
\text { (recrutamento, mobilização, sistemas de } \\
\text { planejamento e comunicação) }\end{array}$ \\
\hline & $\begin{array}{l}\text { Qualidade dos recursos } \\
\text { de entrada }\end{array}$ & $\begin{array}{l}\Rightarrow \text { Nível de habilidades acessadas } \\
\Rightarrow \text { Qualidade técnica dos recursos humanos } \\
\Rightarrow \text { Formato de laboratório estrangeiro }\end{array}$ \\
\hline \multirow{3}{*}{ Não-relacionados } & $\begin{array}{l}\text { Localizações de } \\
\text { empreendimentos } \\
\text { existentes }\end{array}$ & $\begin{aligned} & \Rightarrow \text { Existência de instalações mercadológicas ou } \\
& \text { manufatureiras da empresa no local }\end{aligned}$ \\
\hline & Infraestrutura local & $\begin{array}{l}\Rightarrow \text { Acesso a serviços, infraestruturas ou rede de } \\
\text { relacionamentos para comunicação }\end{array}$ \\
\hline & $\begin{array}{c}\text { Cultura gerencial da } \\
\text { empresa }\end{array}$ & $\begin{array}{l}\Rightarrow \text { Influenciam na atitude de centralização ou } \\
\text { descentralização e decisão sobre a localização } \\
\text { de C\&T }\end{array}$ \\
\hline
\end{tabular}

Fonte: adaptado de Chiesa (1995).

Assim, os fatores de atratividade locacionais estão relacionados diretamente à escolha do projeto inovador. De acordo com Devereux; Griffith; Simpson (2007, p. 8) a 
utilização de tecnologias, inputs e mão de obra qualificadas e similares incentiva as empresas a localizarem-se próximas umas das outras levando em consideração os seguintes fatores demonstrados no Quadro 3.5.

Assim, observa-se que nos projetos de parques tecnológicos a infraestrutura urbana, a proximidade do mercado consumidor e a qualidade de vida dos funcionários são primordiais na tomada de decisão pelas empresas de ciência e tecnologia na escolha da localização. Os fatores locacionais do Quadro 3.5 mostram a importância da relação de proximidade aos mercados consumidores e produtivos maiores. Estes fatores acabam por influenciar diretamente na escolha de localidades mais centrais, ou pelo menos uma tendência de extensificação da área concentrada provocando a expansão dos serviços próximos a rodovias e/ou vias de circulação rápida.

Quadro 3.5 Fatores de atratividade locacional para parques tecnológicos

\begin{tabular}{|c|c|c|}
\hline \multirow{6}{*}{$\begin{array}{l}\text { Fatores de } \\
\text { atratividade }\end{array}$} & \multirow[t]{11}{*}{$\begin{array}{l}\text { Grau de } \\
\text { importância }\end{array}$} & Fator de decisão \\
\hline & & 1. Infraestrutura urbana. \\
\hline & & 2. Proximidade do mercado consumidor. \\
\hline & & 3. Qualidade de vida dos funcionários. \\
\hline & & 4. Acessibilidade ao sistema de transportes. \\
\hline & & 5. Infraestrutura de telecomunicações. \\
\hline \multirow[t]{6}{*}{ locacional } & & 6. Proximidade de Centros de Pesquisa e difusão tecnológica \\
\hline & & 7. Infraestrutura de serviços técnicos e de apoio à empresa \\
\hline & & 8. Proximidade dos fornecedores de insumos \\
\hline & & 9. Qualificação e treinamento da mão de obra \\
\hline & & 10. Incentivos fiscais oferecidos pelo Governo \\
\hline & & 11. Baixo custo de mão de obra \\
\hline
\end{tabular}

Fonte: elaborado pelo autor.

Japão

No Japão, apenas no final dos anos cinquenta, com o excessivo problema da concentração populacional nos grandes centros urbanos e com a conscientização crítica em relação às diferenças ou disparidades entre as regiões, que as políticas regionais adquiriram acepção de planejamento com a implantação de parques tecnológicos. Como exemplo 
dessas disparidades, a renda média entre algumas regiões era considerável. Em 1960, a renda média da área de Tóquio (27\% acima da renda nacional) equivalia a 2,3 vezes a renda média em Okinawa, enquanto a renda média em Kinki estava 15\% acima da média nacional, ou 30\% maior do que a renda média em Hokkaido (GOMES, 1993, p.30).

Nessa perspectiva de planejamento foi implementado no início dos anos sessenta o parque tecnológico de Tsukuba, com atividades de desenvolvimento e produção nas áreas de robótica, mecânica e microeletrônica, sob a inteira responsabilidade do Governo japonês. Esse parque possui numa mesma localidade a Agência Nacional de Desenvolvimento Espacial do Japão (NASDA) ${ }^{28}$, o Instituto Nacional de Indústria Avançada de Ciência e Tecnologia do Japão (AIST) e a Universidade de Tsukuba. O governo japonês numa perspectiva de política regional, promoveu planos voltados para a reestruturação de cidades $^{29}$, áreas específicas para reorganização industrial, com controle de poluição industrial (GOMES, 1993, p. 34). Assim, o governo japonês procurou instalar parques tecnológicos em áreas industriais consolidadas ou estagnadas. A Figura 3.4 mostra a vista aérea do Science Park Tsukuba. O projeto do parque tecnológico foi elaborado com um terminal multimodal de transportes (metrô, rail train e ônibus). O Science Park Tsukuba é considerado uma experiência pioneira em projetos de reestruturação de cidades. A área do parque foi no passado uma região industrial estagnada.
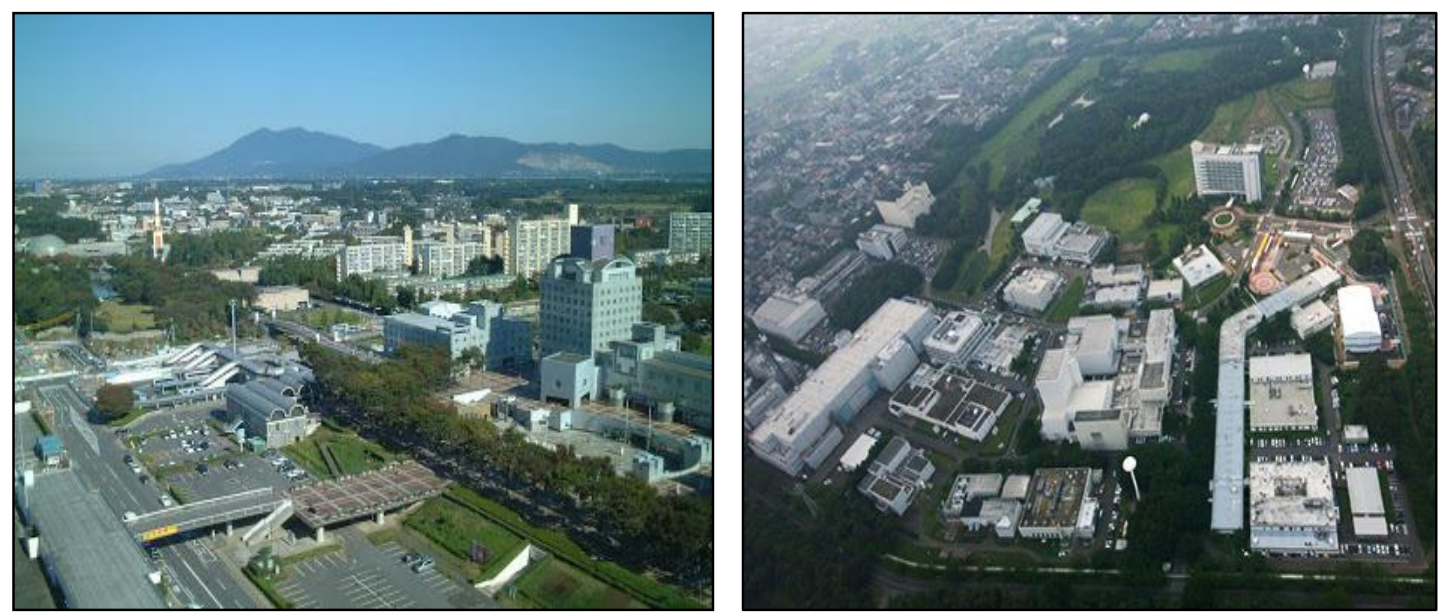

Figura 3.4 Science Park Tsukuba - Japão

Mostra a vista aérea do Science Park Tsukuba. Observa-se o terminal de transportes integrado ao parque tecnológico. O Science Park. Tsukuba é considerado uma experiência pioneira em projetos de reestruturação de cidades. A área do parque foi no passado uma região industrial estagnada.

Fonte: Ribeiro; Spolidoro, 2006.

\footnotetext{
${ }^{28}$ Atualmente incorporada à JAXA - Agência Espacial do Japão.

${ }^{26}$ Em 1962 , o Primeiro Plano Compreensivo para o Desenvolvimento Nacional. Foi ainda instituída no mesmo período a Lei para a Promoção da Construção de Novas Cidades Industriais.
} 
Em seguida estabeleceu planos voltados para a implantação em larga escala de rede de transportes e comunicações ${ }^{30}$. Importante ressaltar que esses planos foram classificados em quatro grupos: (a) planos relacionados ao uso da terra; (b) planos de desenvolvimento; (c) planos relacionados ao investimento público; (d) planos promocionais voltados para determinadas áreas (GOMES, 1993, p. 30). Esses planos objetivavam contribuir para um desenvolvimento industrial mais equilibrado espacialmente, efetivados com medidas que incentivavam a remoção para áreas preferenciais de fábricas localizadas nas três maiores cidades para a sua instalação em regiões cuja expansão o governo pretendeu favorecer.

Dentre esses planos destacou-se o Terceiro Plano Compreensivo, voltado para a desconcentração industrial. Em 1977, iniciou-se o desenvolvimento da política de promoção de relocalização industrial. No início dos anos 1980, foi divulgado o Plano Básico dos Parques Tecnológicos ${ }^{31}$ destacando-se a Lei para a Aceleração do Desenvolvimento Regional baseado nos Complexos Industriais de Alta Tecnologia (GOMES, 1993, p.31). O processo de difusão dos parques tecnológicos no Japão surgiu com base no planejamento governamental, dentro do conceito de polo de crescimento e depois do sucesso do parque de Tsukuba.

Para a sua implementação, o governo japonês selecionou várias cidades médias, com pelo menos 150.000 habitantes, como pontos focais de desenvolvimento, sendo nove cidades selecionadas para receber o padrão de parque tecnológico, obedecendo aos critérios estabelecidos. Esses critérios foram: que os locais eleitos para recepcionar os parques tecnológicos estivessem próximos de alguma estação de trem bala ou aeroporto e; possuíssem porte, no mínimo de cidade média. Essas localidades deveriam apresentar uma área industrial, instituições acadêmicas e área habitacional apropriada e sua infraestrutura física e de comunicações atualizada (LIMA, 1991, p.4).

A operacionalização do processo difusor ocorreu com a divisão do território japonês em três tipos de regiões: (a) as áreas de promoção de relocalização, ou seja, aquelas nas quais se desejou reduzir a concentração de indústrias e que se confundem com as três maiores cidades; (b) as áreas neutras, para as quais não se ofereceram incentivos nem para remoção nem para a instalação de fábricas e que ficavam localizadas principalmente no entorno de Tóquio, Nagoya e Osaka; (c) as áreas de indução industrial,

\footnotetext{
30 Segundo Plano Nacional Compreensivo e várias leis especiais voltadas para áreas agrícolas industriais, relocalização industrial e de localização de fábricas.

${ }^{31} \mathrm{O}$ projeto é de 1981 e representou as bases para o desenvolvimento japonês atual.
} 
que cobririam o restante do país e para onde se desejava atrair os investimentos (LIMA, 1991, p.51).

De acordo com Gomes (1993, p.35), o governo japonês adotou a estratégia de descentralizar as atividades ligadas à produção e a utilização de inovações, desta forma contribuiu para desconcentração nas grandes cidades, favorecendo o desenvolvimento das regiões mais atrasadas. O modelo japonês representou um importante referencial para projetos de desenvolvimento, mas é importante ressaltar que os custos de um projeto de parque tecnológico são elevados. Além do mais, a experiência japonesa mostrou a necessidade de planejamento em escala nacional e de um fundo especial para a promoção de iniciativas locais, redes avançadas de informação e centros de vários tipos para treinamento tecnológico.

\section{França}

$\mathrm{Na}$ França, os parques tecnológicos começaram a ser implantados no início da década de 1970, com a profunda crise vivenciada pelos grandes complexos industriais portuários. A ideia era a revitalização das economias locais a partir da criação destes parques. Nesse momento inicial, o eixo da intervenção do Estado na política local era constituído pelos polos de desenvolvimento ${ }^{32}$.

O mais conhecido é o Sophia-Antipolis (Riviera), criado em 1973, a partir de uma iniciativa privada. Mais tarde, o Estado associou-se também, passando a ser encarregado da comercialização dos terrenos destinados às indústrias e às habitações, ocupando-se também do planejamento da operação. Até o início da década de 1990, havia na França cerca de 50 parques tecnológicos, dos quais cerca de oito apresentavam indícios seguros de continuidade (TAVARES, 1993, p.277-281).

O parque tecnológico Sophia-Antipolis, em 2008, possuía em suas instalações 1.414 empresas sendo a maior parte delas nas áreas de pesquisa e desenvolvimento com ênfase em saúde, química fina, biotecnologia, geologia, agronomia, informática, eletrônica e telecomunicação. O parque tecnológico Sophia-Antipolis estabeleceu em seu planejamento áreas destinadas as empresas inovadoras, moradias e as atividades de serviços. A Figura 3.5 mostra o edifício sede do parque tecnológico Sophia-Antipolis e a

\footnotetext{
32 Os polos de desenvolvimento de Perroux. Ver discussão no Capítulo 2.
} 
vista aérea do parque tecnológico. O parque tecnológico tornou-se um exemplo de planejamento regional e revitalização de áreas estagnadas.
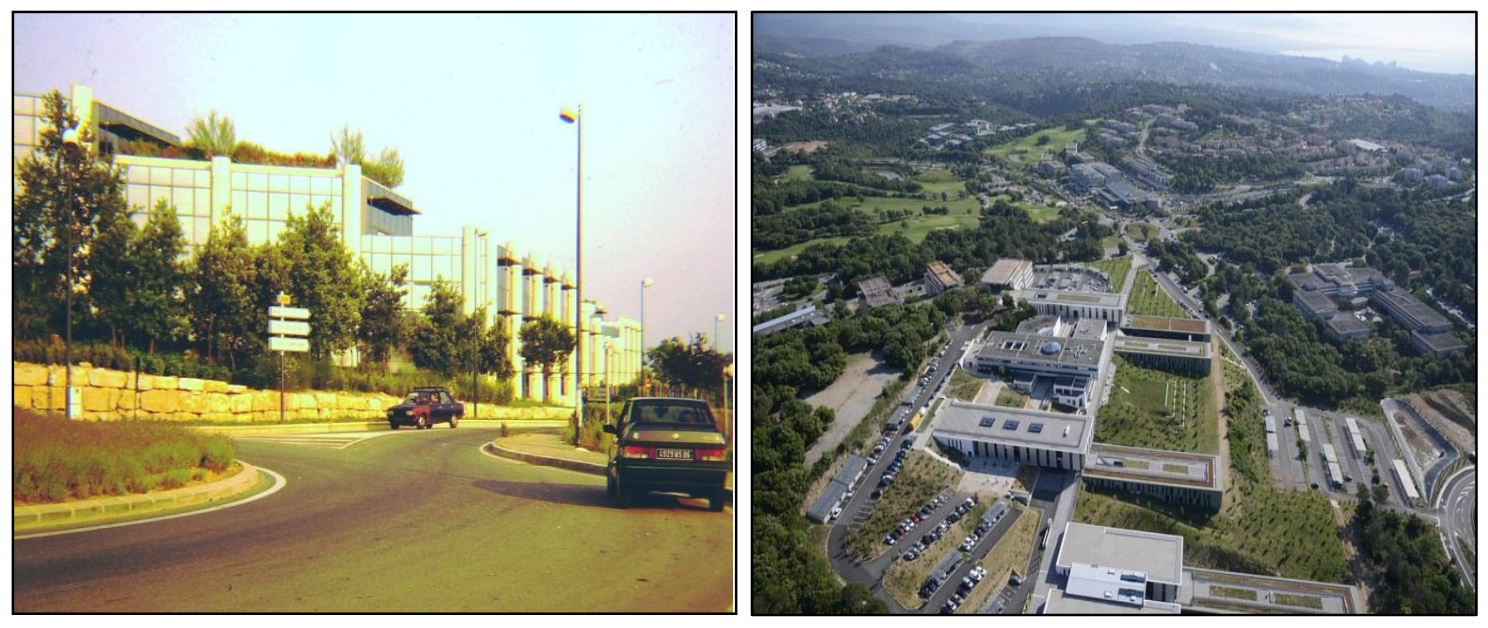

Figura 3.5 Centro de P\&D e vista aérea do parque Sophia-Antipolis

Mostra o edifício sede de pesquisa e desenvolvimento do parque tecnológico Sophia-Antipolis.

Mostra a vista aérea do parque tecnológico considerado um modelo de planejamento tradicional de parque tecnológico - polo de desenvolvimento.

Fonte: Ribeiro; Spolidoro, 2006.

O desenvolvimento local no país acompanhou as políticas, projetos ou programas de ciência e tecnologia que buscavam descentralizar as atividades produtivas. A experiência francesa com parques tecnológicos e a sua distribuição espacial mostrou a importância da descentralização produtiva para o desenvolvimento e progresso no território.

\section{China}

$\mathrm{Na}$ China, com o objetivo de atrair para os parques tecnológicos as empresas de inovação, o governo chinês, no início da década de 1990, criou parques em 53 metrópoles num programa de planejamento intitulado Ниоји (tocha), voltado para promover e difundir inovações. Destacaram-se os parques tecnológicos de Pequim e o de Xangai. O modelo chinês visava por meio de políticas públicas atrair investimentos do setor privado nos parques tecnológicos. 
De acordo com Hu (2007, p. 16) estas políticas eram para um crescimento de longo prazo. Os parques tecnológicos chineses ofereciam diversos incentivos políticos e fiscais para atrair novos investimentos e empresas tais como: isenção de cobrança de imposto de renda nos dois primeiros anos; licença para importação de materiais e componentes utilizados na produção de bens para exportação. Todavia, estes benefícios eram concedidos apenas àquelas empresas que desenvolviam produtos de base tecnológica certificados por uma agência do governo chinês. Além do mais, essas empresas tinham que gastar pelo menos 3\% do lucro em Pesquisa e Desenvolvimento (P\&D), sendo avaliadas anualmente para que fossem mantidos os incentivos governamentais.

Dentre as experiências chinesas destaca-se o parque tecnológico Zhongguancun Science Park - Pequim que é considerado referência internacional no que ser refere a inovações. As áreas de pesquisa e desenvolvimento no parque são: cultura criativa, tecnologia da informação, big data e hardware inteligente. O parque possui em sua área uma empresa responsável por financiamentos e criação de empresas de base tecnológica. Dentre as multinacionais instaladas no parque estão a Microsoft Research Asia, Google, Intel, Motorola, Sony\&Ericsson, AMD e Oracle. A Figura 3.6 mostra em destaque o edifício sede do parque com estrutura arquitetônica moderna em destaque e, de um outro ângulo sua inserção dentro do parque com paisagismo harmônico.
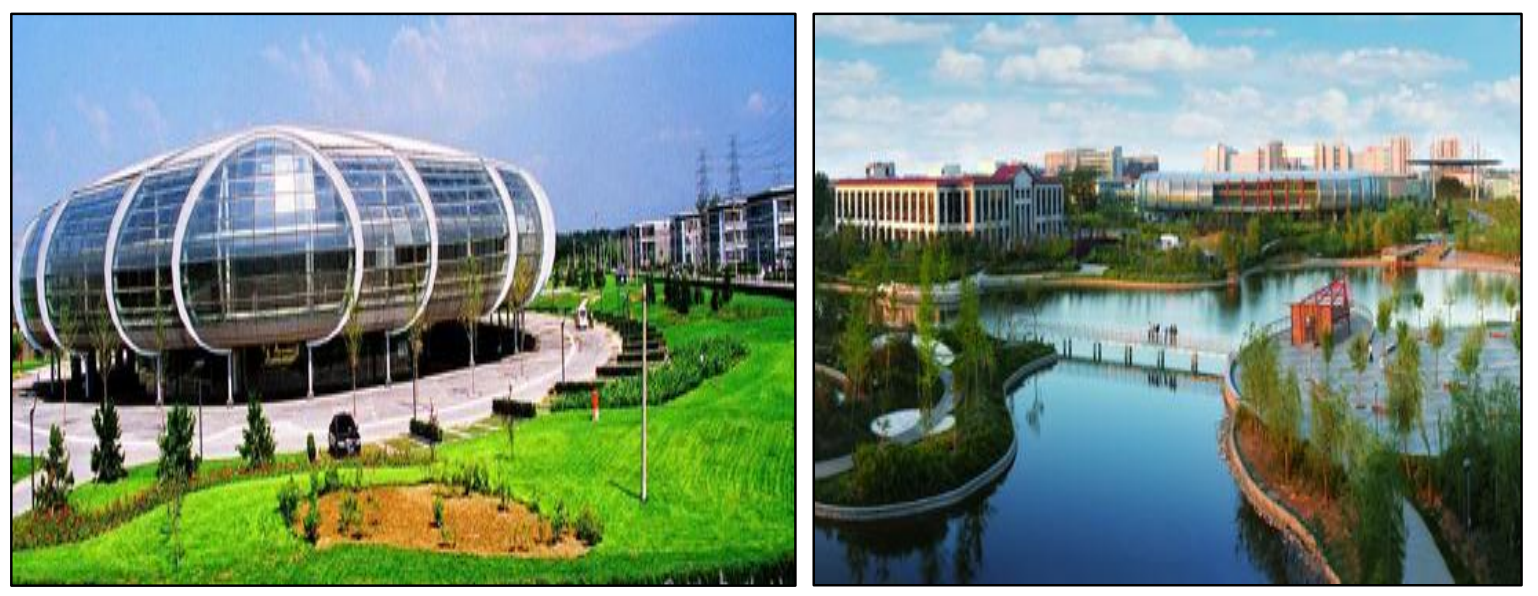

Figura 3.6 Zhongguancun Science Park - Pequim

Mostra em destaque o edifício sede do parque com estrutura arquitetônica moderna em destaque e, de um outro ângulo sua inserção dentro do parque com paisagismo barmônico. O Zhongguancun Science Park - Pequim se tornou referência internacional em inovações.

Fonte: Ribeiro; Spolidoro, 2006. 
O modelo chinês apresentou uma peculiaridade, a saber: o desenvolvimento de inovação esteve diretamente ligado ao crescimento das economias do sudeste asiático. $\mathrm{Hu}$ (2015) afirma que o desenvolvimento científico dos parques tecnológicos chineses demandou políticas públicas de fortalecimento das instituições de C\&T, a proteção dos direitos de propriedade intelectual, a integração com a economia mundial e a expansão de empresas de inovação na economia interna. Chu (2005) afirma que as vantagens oferecidas pelos parques chineses são principalmente os recursos tecnológicos disponíveis e as políticas de incentivos por meio de financiamentos.

\section{Itália}

Na Itália, segundo Frassoldati (2008, p.2) os parques tecnológicos começaram a ser implementados nos anos 1990 surgindo como novos espaços de inovação e ao mesmo tempo de reorganização espacial. Castels; Hall (1994) afirmam que em sua concepção original estes parques pretendiam valorizar as identidades locais e a remodelação de várias áreas urbanas estagnadas do processo industrial. Castells (1994) afirma que o modelo italiano de parques tecnológicos teve como estratégia uma tentativa de desenvolvimento regional e de reorganização espacial ocasionado pelo deslocamento das grandes indústrias/corporações para áreas com custos menores.

Dessa forma, os parques tecnológicos italianos surgiram numa tentativa de regeneração de áreas urbanas que foram "abandonadas" e deterioradas pelo processo de acumulação tendo como objetivo o desenvolvimento regional, a reindustrialização destas áreas e a criação de sinergias entres os atores.

Diferenciando-se das demais experiências, os parques tecnológicos italianos foram de iniciativas locais/municipais e surgiram sob a forma de Greenfield plants, como os parques de Trieste e Turim. A Figura 3.7 mostra o edifício sede do parque tecnológico Area Science Park e a vista aérea do parque tecnológico baseado no projeto de planejamento para greenfields plants inserido em área de uso controlado para preservação do meio ambiente.

Outros parques tecnológicos surgiram numa tentativa de regeneração urbana, voltados para quatro importantes segmentos a saber: nano e biotecnologia; tecnologia e informação; indústria limpa e; biogenética. Nestes segmentos destaca-se o parque tecnológico de Vega em Marghera-Veneza, considerado um projeto único de regeneração 
urbana combinado com a recuperação do ambiente, preservação do patrimônio, valorização e a requalificação de cidades. Importante mencionar ainda, o parque tecnológico de S. Agabio em Novara caracterizado por iniciativas locais/ municipais para a renovação urbana, numa tentativa de distribuição de novas funções aqueles espaços outrora abandonados.
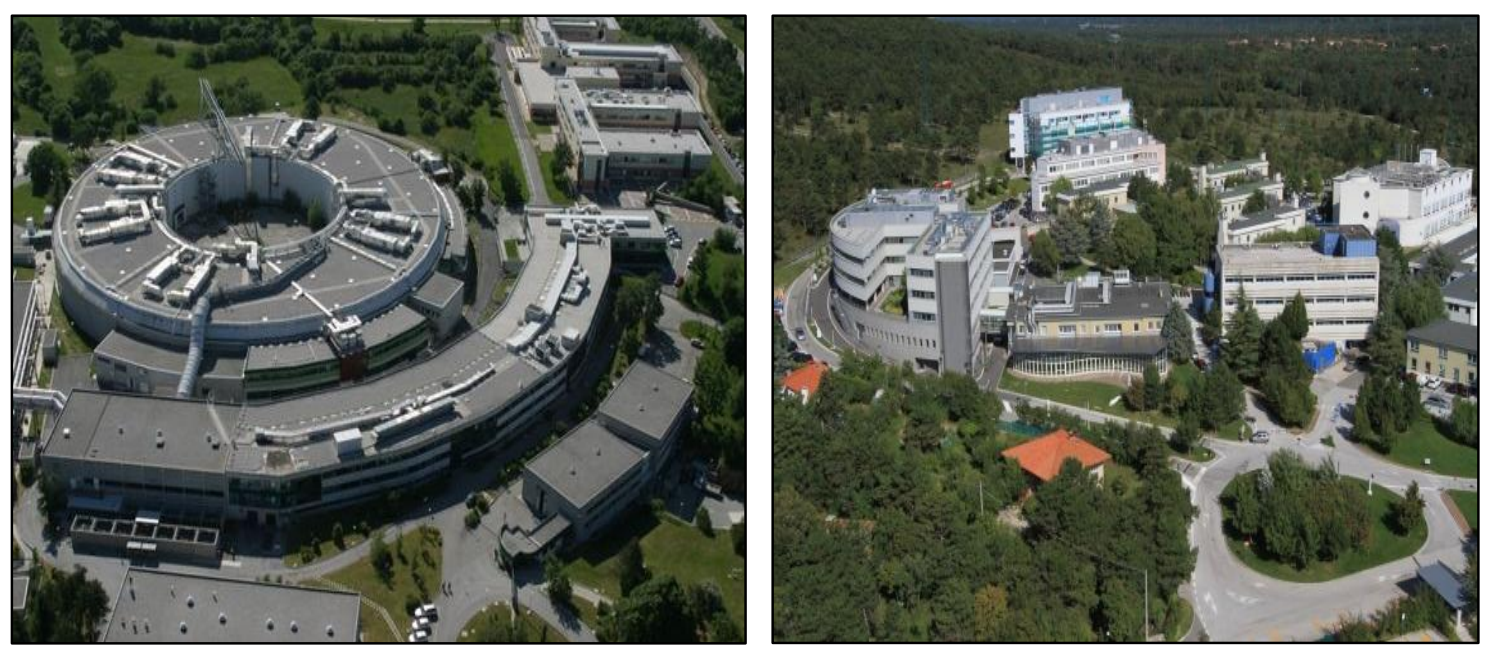

Figura 3.7 Area Science Park-Trieste - Itália

Mostra o edifício sede do parque tecnológico Area Science Park.

Mostra a vista aérea do parque tecnológico baseado no projeto de planejamento para greenfields plants inserido em área de uso controlado para preservação do meio ambiente.

Fonte: Ribeiro; Spolidoro, 2006.

Diante das experiências apresentadas é possível estabelecer uma diferença entre o modelo de parques tecnológicos dos Estados Unidos (Silicon Valley) e o do Japão (Tsukuba). Enquanto o modelo norte-americano foi desde o princípio um empreendimento de iniciativa privada tendo à frente grandes corporações como Intel e Hewlett Packard (HP), o modelo japonês foi essencialmente, no início, todo implementado pelo Governo que construiu inúmeros centros de pesquisas com base no planejamento.

Os parques tecnológicos chineses estão voltados para a atração de empresas multinacionais para a promoção de suas indústrias nacionais ao mercado global. Consiste numa tentativa de aumentar a competitividade das indústrias nacionais com a presença de multinacionais. Na Itália, os parques tecnológicos são vistos como formas espaciais capazes de promover o desenvolvimento econômico.

Os modelos de parques tecnológicos comentados possuem algumas características que são peculiares: a) o desenvolvimento de inovações nesses países predomina sob a forma de parques tecnológicos (empresas, centros de pesquisas e 
universidades); b) as áreas onde são implementados eram áreas com estrutura industrial anterior, ou seja, os parques implementados visavam à renovação dessa estrutura; c) os parques tecnológicos são utilizados como instrumentos de políticas de desenvolvimento; d) a intervenção ou participação do Estado é fundamental, seja na fase inicial, ou durante a consolidação dos parques tecnológicos. Importante mencionar ainda, de acordo com Vedovello; Judice; Maculan (2006), os parques tecnológicos apresentam um elevado grau de diversidade e heterogeneidade, pois aglutinam diferentes interesses, motivações e expectativas dos vários agentes envolvidos.

As experiências internacionais com parques tecnológicos mostram que a acumulação flexível vem interferindo na dinâmica territorial mundial. Estes parques impulsionam as empresas a operarem com elevados níveis de competitividade e alto conteúdo inovador em áreas que ofereçam vantagens locacionais mostrados no quadro 3.5. Dessa forma, alguns territórios se enquadram nestes fatores de atratividade e ocupam papel de destaque no regime de acumulação capitalista enquanto outros menos devido a problemas de desenvolvimento em seus territórios.

No Brasil, os parques tecnológicos surgiram para incentivar o empreendedorismo, a geração de empregos e impostos, numa perspectiva de inserção na acumulação flexível. Nos parques tecnológicos brasileiros existe uma ênfase maior na geração de spin-offs ${ }^{33}$ e na oferta de infraestrutura de serviços do que na transferência de inovações propriamente dita.

Assim, surgiram as primeiras experiências com parques tecnológicos no Brasil. Mesmo diante das suas especificidades os processos de instalação de parques tecnológicos se reproduzem no território brasileiro. A análise da evolução socioeconômica brasileira com se verá adiante mostram os fatores que contribuíram para a inserção do país na acumulação flexível e para o surgimento de parques tecnológicos.

\footnotetext{
33 Divisão e transferência de inovações entre as empresas.
} 


\section{Capítulo 4}

\section{INICIATIVAS DE PARQUES TECNOLÓGICOS NO BRASIL}

“(...) os diversos agentes sociais e econômicos não utilizam o território de forma igual. Isso representa um desafio às planificações regionais, na medida em que as grandes firmas que controlam a informação e a redistribuem ao seu talante, têm um papel entrópico em relação às demais áreas e somente elas podem realizar a neg-entropia. O espaço é assim desorganizado e reorganizado a partir dos mesmos polos dinâmicos. $\mathrm{O}$ fato de que a força nova das grandes firmas neste período científico-técnico traga como consequência uma segmentação vertical do território, supõe que se redescubram mecanismos capazes de levar a uma nova horizontalização das relações que esteja não apenas ao serviço do econômico, mas também do social."

(SANTOS, Milton. A revolução tecnológica e o Território: realidades e perspectivas. São Paulo: AGB, n. 09, 1992) 


\subsection{O desenvolvimentismo e o cenário produtivo brasileiro até o final dos anos 1960}

Falar do processo produtivo brasileiro, os seus aspectos socioeconômicos e os seus impactos no território usado para contextualizar o surgimento de parques tecnológicos no Brasil é o foco desse capítulo. Pretendo aqui retomar a visão de Milton Santos (1979) de que existe uma importância central em explicar as transformações no território usado, principalmente em países em desenvolvimento ${ }^{34}$ pois é a única forma de levar em conta as implicações temporais (passado - presente) na organização do território.

O contexto desta periodização considera as três fases apontadas por Diniz; Crocco (2006, p.10), a primeira delas, após a Segunda Guerra Mundial, até os anos 1970, denominada política desenvolvimentista (teorias Keynesianas), a segunda, a partir dos anos 1970, denominada fase neoliberal ortodoxa e a terceira, a partir do final dos anos 1990, uma fase denominada neodesenvolvimentista.

As atividades econômicas desenvolvidas no território brasileiro a partir da segunda metade do século XVII e no XVIII constituíam-se como frentes de ocupação do território. Excluindo-se a faixa litorânea pertencente à agricultura, o que restava era área para o extrativismo no extremo Norte, a mineração no Centro-Sul e a pecuária que recobria grandes espaços no território. As atividades econômicas no território eram esparsas. Até então, cada região possuía sua especialidade, sendo a ocupação do território bastante desconcentrada. Os complexos regionais eram pouco integrados, pela ausência de meios de comunicação entre estes, tendo cada região sua própria economia.

No início do século XIX, com o desenvolvimento da economia cafeeira, ocorreu a desconcentração das atividades econômicas, diminuindo os ciclos de cana-deaçúcar e a mineração. Nesse período, surgiu o Estado Nacional, atuando, o Brasil, como país exportador de produtos primários e importador de manufaturados. Houve um processo de distribuição espacial das atividades econômicas pelo território ocasionada pela ocupação funcional do território. Esse processo de ocupação deu início a formação e integração do mercado nacional, a partir do desenvolvimento da economia cafeeira (1850) até a crise de 1929 (BECKER; EGLER, 1994, p.73).

O complexo exportador de café envolvia um setor agrário e industrial produtivo e um setor mercantil urbano que se manteve dominante, expandindo-se vigorosamente pelas condições criadas: altas de preços, a ampla disponibilidade de terras graças à extensão das ferrovias, a oferta abundante de trabalho gerada pela imigração

\footnotetext{
${ }^{34}$ Em suas considerações Santos (1979) utiliza o termo países periféricos.
} 
maciça e a transferência de renda para o capital cafeeiro promovida pelo Estado (BECKER; EGLER, 1994, p.73).

Nas primeiras décadas do século XX, Cidade et al (2008, p. 26) afirma que ainda no contexto da acumulação intensiva se caracterizava como uma sociedade tradicional, com grande contingente populacional rural, um conjunto de regiões relativamente isoladas. De acordo com Mamigonian (1987, p.69) neste período de início da industrialização, as atividades produtivas eram pré-industriais e divididas em dois setores, o da agricultura e o outro voltado para a produção de bens de equipamento como aqueles para a construção civil e as máquinas para o interior das fábricas.

Segundo Becker; Egler (1994, p. 74), as principais condições criadas pelo complexo exportador cafeeiro para o processo de industrialização brasileiro foram: a) a demanda por bens, salários nas áreas de produção e no seu segmento urbano; b) a existência de lucros comerciais excedentes na burguesia cafeeira; c) a ação do Estado concedendo farto crédito à agricultura, permitindo aos bancos se transformarem em empreendedores industriais e estabelecendo proteções tarifárias; d) a disponibilidade de mão de obra nas cidades; e) a capacidade de importar meios de produção, alimentos e bens de consumo para a reprodução de força de trabalho ${ }^{35}$.

Com essas condições houve a expansão da indústria de bens de consumo, principalmente a têxtil. Em 1907, o Censo geral das indústrias brasileiras registrou 3.258 estabelecimentos e 150. 841 operários sobressaindo a industrial têxtil (cerca de 60\%) e de alimentação (15\%) concentrada no Rio de Janeiro (33\%), São Paulo (16\%) e Rio Grande do Sul (15\%). No censo de 1920, o número de estabelecimentos industriais tinha crescido para 13.336, com 275.512 trabalhadores indicando também a instalação da pequena indústria de aço (BECKER; EGLER, 1994, p.73-6).

Os dados acima demonstram um movimento de expansão industrial no território, mas ainda inicial. O mercado nacional ainda não estava integrado, acompanhava uma dinâmica regional ainda relacionada com a concentração da propriedade e a rigidez tecnológica, pois a indústria utilizava as técnicas atualizadas e disponíveis nos países centrais.

A partir de 1929, a economia cafeeira entrou em crise, devido ao contexto mundial (Primeira Guerra Mundial - 1914-1918) e a desvalorização da moeda brasileira em face da estrangeira, dificultando as importações de produtos manufaturados. Este

\footnotetext{
35 Koshiba (1993, p.279) aponta ainda a criação de um mercado interno.
} 
cenário contribuiu para um processo de industrialização marcado pela substituição de importações. Nos anos subsequentes a crise entre 1929 e 1937 enquanto, as importações caíam em $23 \%$, a produção industrial acusava um aumento da ordem de $50 \%$. No mesmo período, as aplicações de capital realizados no país tenderam a mover-se da área dos investimentos de infraestrutura (transportes, energia) para a indústria de transformação. Esse processo de industrialização foi denominado substituição de importações, uma resposta rápida ao período de recessão ou estagnação da economia internacional (BECKER; EGLER, 1994, p.76).

O processo de substituição de importações foi dividido em duas fases: a primeira de industrialização extensiva quando ocorreu a substituição na faixa dos bens de consumo corrente, de alguns produtos intermediários e bens de capital, cuja tecnologia exige baixa densidade de capital e mesmo, de bens de consumo duráveis "leves" produzindo-se um alargamento de capital com uso abundante de mão de obra e expansão horizontal do mercado. A segunda fase foi a de industrialização intensiva em que ocorreu a substituição pelos bens de produção pesados e pelos bens duráveis de consumo de alto valor unitário, quando a utilização de técnicas intensivas de capital diminuiu o ritmo de crescimento do emprego industrial, dando lugar a uma expansão vertical do mercado, por meio da concentração de renda (BECKER; EGLER, 1994, p.78).

De acordo com Mello (1982, p. 110) esse período, caracterizado pela dinâmica da acumulação endógena e da expansão industrial, denominou-se industrialização restringida ${ }^{36}$, porque as bases técnicas e financeiras da acumulação são insuficientes para que se implante, de uma só vez, o núcleo fundamental da indústria de bens de produção, que permitiria à capacidade produtiva crescer adiante da demanda, autodeterminando o processo de desenvolvimento industrial.

Nesse período, a acumulação prosseguiu pela via da expansão industrial com base urbana. De acordo com Cidade et al (2008, p. 26), esta industrialização tinha como objetivo a expansão das atividades produtivas para o interior, e o crescimento e a consolidação das áreas urbanas. Este período marca a tentativa de inserção do Brasil no regime de acumulação intensiva ${ }^{37}$ com investimentos estatais e a intervenção econômica direta do Estado na economia.

\footnotetext{
36 Autores como Harvey (2014) apontam este processo de acumulação no Brasil como fordismo periférico.

${ }^{37}$ As características da acumulação intensiva foram apresentadas no Quadro 2.1 do Capítulo 02.
} 
Esta expansão industrial se concentrou na Região Sudeste. Entre 1931 e 1937, o Estado protegeu pequena indústria de bens de consumo, proibindo a importação de novos equipamentos. Assim, o crescimento industrial atingiu uma taxa média de 8,4 \% contra 2,2 \% da agricultura neste período (BECKER; EGLER, 1994, p. 77). A participação de São Paulo na indústria nacional em 1919 passou de 32\% (do PIB) para 41\% em 1939, saltando para 49\% em 1949, e entre 1955 e 1956, antes do Plano de Metas, alcançaria 52\% do PIB.

Os dados acima mostram o crescimento da participação de São Paulo na produção industrial e o início do seu processo de concentração produtiva. No conjunto da indústria da transformação, no período de 1919-1949, apenas três regiões não perderam participação relativa no total da indústria brasileira: Centro-Oeste, dada a sua ínfima base industrial no início do período; Santa Catarina, com modesta, porém firme expansão, e Minas Gerais. Entre os que mais perderam estava o Nordeste, que caiu dos $16 \%$ para $9 \%$ (CANO, 1988, p. 102).

Segundo Mello (1982, p. 110) período seguinte denominado de industrialização pesada ou retardatária implicou numa descontinuidade tecnológica, uma vez que, desde o início tornou-se essencial um maciço volume de investimentos em inovações. Estas praticamente não estavam disponíveis no mercado internacional, pois eram controladas pelas grandes empresas dos países industrializados ${ }^{38}$. Essa industrialização pesada se constituía basicamente nas indústrias consideradas essenciais ao desenvolvimento: combustíveis e lubrificantes, matérias-primas e equipamentos.

De acordo com Becker; Egler (1994, p.82), adotou-se uma política de industrialização favorável ao capital monopolista privado (fordismo periférico), um capitalismo politicamente chamado "desenvolvimentismo". O setor privilegiado pelo Estado neste momento foi o de bens duráveis. Com isso organizou-se um modelo de desenvolvimento em “tripé”: a) produção de bens não-duráveis (capital privado nacional); b) produção de bens duráveis (capital estrangeiro) e, c) produção de bens de produção (capital estatal).

Esse modelo foi controlado através do Plano de Metas (1956-1960), estabelecendo uma estratificação formal da economia e uma reestruturação qualitativa das relações entre a economia e o Estado (BECKER; EGLER, 1994, p. 82-3). Cohn (1977, p.304) afirma que adotou-se uma política econômica liberal e não intervencionista por

\footnotetext{
${ }^{38}$ Esse controle das inovações pelos países avançados no regime de acumulação intensiva se manteve no flexível. Os parques tecnológicos surgiram neste contexto para promover mudança neste paradigma.
}

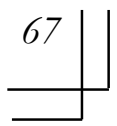


parte do Estado, marcando a definitiva emergência do setor industrial como a área mais dinâmica da economia brasileira em que o produto industrial aumentou $60 \%$.

O Plano de Metas acentuou a histórica concentração da atividade econômica no Sudeste, completando a integração vertical da indústria, através dos investimentos em capital fixo sobre o território em obras de geração e distribuição de energia e insumos industriais básicos. Foi a partir desse plano que o Estado modernizou as redes periféricas, ampliando as dimensões do mercado interno (BECKER; EGLER, 1994, p.115).

Segundo Baer (1986, p. 393) durante esse período, o governo brasileiro colocou a industrialização de "Substituição de importações" (ISI) no centro de sua estratégia de desenvolvimento. Os instrumentos dessa política industrial objetivavam a proteção/ atração das novas indústrias através de tarifas de controle cambial. O período foi marcado por incentivos especiais ao capital estrangeiro e a criação do BNDES (Banco Nacional de Desenvolvimento), a fim de prover financiamentos de longo prazo para as empresas estatais.

Essa política industrial completou o ciclo de substituição de importações, um processo denominado industrialização tardia e associado ao capital estrangeiro (BECKER; EGLER, 1994, p.85). Dentre os aspectos positivos, destaca-se a criação da Petrobrás - com o monopólio da extração e refino de petróleo. O Estado passou a coordenar as suas ações, com vistas a incrementar o processo de industrialização, como exemplo disso, a criação em 1959, da Superintendência do Desenvolvimento do Nordeste - SUDENE (BAER, 1986, p. 393).

No entanto, essa política industrial também apresentou aspectos negativos como as pressões inflacionárias, o descuido com o setor agrícola e o das exportações, a má alocação dos recursos, o desempenho decepcionante da indústria como geradora de empregos e principalmente o aumento dos desequilíbrios regionais.

Foram justamente esses aspectos que contribuíram para que a ISI atingisse o seu limite, pois se alcançou um grau de capacidade e diversificação produtiva que esgotava a capacidade de absorção "passiva" de um mercado originalmente tornado disponível pela contração da oferta de produtos importados, sobretudo porque se caminhava no sentido da produção de bens mais complexos e de maior preço e difusão mais limitada pela capacidade aquisitiva (COHN, 1977, p.307).

Entre 1949-1955, a indústria de transformação no Brasil crescera à taxa média anual de 8,9\% e no período de 1955-1962 com a realização do Plano de Metas elevou-se para 10\%. A concentração industrial em São Paulo aumentou entre 1956 e 1950 na mesma 
proporção de crescimento do período anterior 1949-1955 (10,8\%). Sua taxa média anual de crescimento industrial, que fora de 6,2 \% entre 1939 e 1949 aumentou entre 1949 e 1959 para 7,8 \%, mantendo-se na década seguinte, na média de 6,7\% (CANO, 1988, p. 87-8). Estes dados mostram o movimento de concentração da atividade industrial em São Paulo.

Cano (1988, p.92) afirma que a partir de 1967, via expansão do setor de bens de consumo durável ocorreu a retomada do crescimento denominado "milagre econômico". Com o rearranjo das finanças públicas federais, tornou-se possível retomar o gasto público, ampliando-se a demanda por equipamentos e por construção civil. Este período foi marcado por políticas de arrocho salarial impostas e o aumento da concentração de renda, propiciando a expansão dos bens de consumo durável, seguido pelos bens de capital. Os bens intermediários e de infraestrutura aumentaram quantitativamente devido aos investimentos de grande porte previstos no Plano de Metas. Foram implementados alguns investimentos importantes no ramo químico e a retomada do setor de construção civil (CANO, 1988, p.92).

Em relação à indústria de transformação os que aumentaram a concentração em termos de distribuição espacial das indústrias foram: São Paulo (aumentou de $48 \%$ para 55,6\%), o Paraná, Centro-Oeste, Rio de Janeiro, Bahia e a Região Norte. Entre os que diminuíram estava o Nordeste $(9,1 \%$ para $6,9 \%)$, embora nessa década, tenha acelerado seu ritmo de crescimento ainda inferior à média nacional (CANO, 1988, p. 104). Nesse período, houve o reforço ao processo de concentração industrial, na medida em que se instalam as chamadas indústrias pesada, principalmente em São Paulo, graças à sua maior diversidade industrial previamente existente.

\subsection{Concentração industrial e ações de gestão no território brasileiro}

Com o movimento de concentração industrial na Região Sudeste do país, o território foi tanto um instrumento, quanto um produto do regime de acumulação intensiva. Para tanto foram estabelecidas neste período políticas de gestão do território ${ }^{39}$. O desenvolvimentismo reforçou o papel da urbanização como base para a industrialização, favorecendo novamente a concentração econômica no Sudeste. A maior parte dos investimentos governamentais em indústria, transporte e energia foram para o Sudeste devido aos compromissos assumidos com os interesses desses Estados. As corporações

\footnotetext{
39 Paviani $(1997$, p.3) afirma que o conceito de gestão do território corresponde ao poder (e ações de poder) do Estado sobre o território exercido com legitimidade social e soberania.
} 
estrangeiras favoreceram a localização na área metropolitana de São Paulo e nas suas vizinhanças, enquanto o Rio de Janeiro - locus da maioria das companhias estatais experimentou um pronunciado declínio (BECKER; EGLER, 1994, p.86-7).

Segundo Cano (1988, p.94) o desenvolvimento regional foi promovido por políticas públicas de incentivo por parte do Estado. Essas políticas foram representadas, pelas leis aprovadas a partir de 1961 para o Nordeste; de 1963 para a Amazônia; de 1967 para a constituição da Zona Franca de Manaus ${ }^{40}$ e a partir de 1969 para o desenvolvimento do Espírito Santo. A política regional de incentivo foi de grande importância para o crescimento industrial das regiões Norte e Nordeste, além da expansão verificada em outros estados através de políticas estaduais de incentivos (Minas Gerais e Espírito Santo).

A concentração industrial e a consequente demanda em expansão propiciou um movimento de integração do território por meio das redes de transportes. Foram construídos $12.169 \mathrm{~km}$ de rodovias e pavimentados $7.215 \mathrm{~km}$, ampliando-se as rodovias federais de 22. $250 \mathrm{~km}$, para $35.419 \mathrm{~km}$. Os sistemas rodoviários federal e estadual e municipal foram articulados principalmente no Centro-Sul do país, enquanto rodovias de penetração articularam o Norte e Sul da área core. A capacidade instalada de energia hidrelétrica aumentou de três milhões de kW em 1955 para quase cinco milhões de kW em 1961. Entre 1950 e 1960, a produção de petróleo aumentou de dois milhões de barris/ano para 30 milhões, e a produção de aço cresceu de 1.150 ao ano para 2.500 toneladas (BECKER; EGLER, 1994, p.84-5).

Conforme Becker; Egler (1994, p.114), a estrutura regional resultante da industrialização poderia ser representada por três grandes unidades, a área core e sua periferia integrada, as periferias deprimidas e a fronteira de recursos, representando não apenas espaços geográficos diferenciados, mas também distintos momentos históricos. Nelas estavam presentes desde formas simples de produção marcadas por profunda interdependência dos fatores naturais até complexas estruturas urbano-industriais, resultantes de uma rápida acumulação de trabalho social.

A área core e a periferia integrada representavam o Brasil metropolitano em 1960, gerando cerca de $85 \%$ da renda nacional e com um fluxo intenso de mercadorias, força de trabalho e capitais. A diferenciação no interior do Centro-Sul já indicava tendências de especialização regional no quadro de uma sociedade industrial. Dentro da região, distinguiam-se a área core e as periferias de desenvolvimento dinâmico e lento. $\mathrm{O}$

\footnotetext{
${ }^{40}$ A Zona Franca de Manaus abriga o Polo Industrial de Manaus que com se verá adiante no tópico 4.7 foi um importante resultado dessas políticas de desenvolvimento regional.
} 
core era o núcleo polarizador do Sudeste, de acordo com a regionalização oficial no final da década de 1960 correspondente às grandes metrópoles nacionais, São Paulo e Rio de Janeiro (BECKER; EGLER, 1994, p.117).

Segundo Becker; Egler (1994, p.119) as periferias deprimidas correspondiam a região Nordeste e algumas áreas da região Norte. O nordeste era uma região muito menos desenvolvida que a sudeste. No entanto não era simplesmente uma região complementar à área core, porque possuía dinâmica interna própria e certa autonomia em que as relações intra-regionais eram superiores às inter-regionais, embora menos intensas do que as verificadas na periferia integrada, pois se tratava de uma região de economia agrária baseada nas relações mercantis que retardaram seu desenvolvimento, convertendo-a numa periferia deprimida. Os núcleos polarizadores do Nordeste localizavam-se na faixa litorânea, apresentando-se como regiões complementares: o Meio-Norte, o oeste da Bahia e o norte de Goiás. A ausência de uma base industrial impediu o Nordeste de articular suas regiões, ficando sob a crescente influência do Centro-Sul.

A terceira unidade, denominada fronteiras de recursos, compreendeu a expansão em direção ao Centro-Oeste como oportunidade de ampliação da fronteira agrícola e pecuária. A região Norte não possuía uma organização territorial complexa, norteada apenas pela atividade extrativista com exceção de Belém e Manaus que dominavam o seu território no âmbito regional, a partir do desenvolvimento de uma rede de transportes pouco consolidada. Em 1953 essas redes foram desenvolvidas prioritariamente na construção do caminho pioneiro entre Goiás e Pará e, mais tarde consolidadas com a construção da rodovia Belém-Brasília (BECKER; EGLER, 1994, p.122).

Diante das disparidades regionais verificadas nas três unidades mencionadas, o Estado tentou solucioná-las por meio de políticas estratégicas de institucionalização das macrorregiões, destacando-se entre elas, a Superintendência do Desenvolvimento da Amazônia $^{41}$ (SUDAM), a Superintendência do Desenvolvimento do Centro-Oeste ${ }^{42}$ (SUDECO) e a Superintendência do Desenvolvimento do Sul ${ }^{43}$ (SUDESUL).

\footnotetext{
${ }^{41}$ A autarquia foi criada em 1966 e tinha entre outros objetivos: a ampliação da rede de transportes e comunicação; o reaparelhamento das indústrias existentes e a implantação de novas; a criação de parques agropecuários e minerais.

${ }^{42}$ A autarquia foi criada em 1967, tendo entre outros objetivos: a elaboração de programas, pesquisas e levantamentos do potencial econômico da região; a fixação de parques de crescimento capazes de induzir o crescimento das áreas vizinhas.

${ }^{43}$ A autarquia foi criada em 1967, se empenhou além de outros objetivos em diminuir as disparidades microrregionais e a promoção do surgimento de parques de desenvolvimento.
} 
Essas autarquias apresentaram importantes avanços no desenvolvimento regional brasileiro nesse período, mas foram incapazes de solucionar ou amenizar os problemas decorrentes dos anos anteriores provocados pelas contradições ou desequilíbrios regionais provenientes da industrialização via substituição de importações e a consequente estagnação econômica.

Nas décadas seguintes, diante desse quadro de estagnação, os governos subsequentes implementaram incentivos tributários e creditícios aos investimentos em regiões atrasadas e em setores menos favorecidos; medidas fortes de estabilização econômica (reajustes drásticos de preços controlados, indexação) e um grau de autonomia às empresas estatais nas suas decisões sobre os preços e os investimentos. São Paulo neste período continuou a ser a área mais desenvolvida e urbanizada do país.

\subsection{Políticas econômicas e desenvolvimento produtivo até o início dos anos 1990}

O contexto neste período é discutido a partir das fases estabelecidas por Diniz; Crocco (2006, p.10) especificamente, a segunda, que surgiu a partir dos anos 1970 e se manteve até o início dos anos de 1990, denominada fase neoliberal ortodoxa. Cidade et al (2008, p.30) afirma que mesmo com os prolongamentos da modernização conservadora da fase anterior, neste período foram implementadas políticas de desenvolvimento, entre elas o Primeiro Plano Nacional de Desenvolvimento - I PND (1972-1974). O I PND estabeleceu como áreas prioritárias para investimentos, a siderurgia, a petroquímica, o transporte, a construção naval, a energia elétrica e a mineração.

Os anos de 1970 foram marcados pelo agravamento da crise capitalista mundial. Neste cenário o desenvolvimento econômico brasileiro passou por mudanças estruturais. Para apoiar estas mudanças as políticas públicas estavam voltadas para a reorganização das atividades financeiras. A finalidade desta reorganização era aumentar o volume de investimentos estrangeiros diretos na economia.

Baer (1986, p. 400) afirma que o impacto positivo dessas políticas foi o crescimento, chamado Milagre Econômico verificado neste período em que a taxa de crescimento industrial foi de $12,6 \%$ ao ano. Para manter taxas de crescimento altas, o Segundo Plano Nacional de Desenvolvimento Econômico (II PND) previa grandes investimentos e taxas de crescimento para a maioria dos setores, incluindo as indústrias de base. 
Esse período caracterizou-se pela concentração dos investimentos estatais em certas indústrias de base (mineração, metalurgia, química e siderurgia) contribuindo para o desenvolvimento da industrialização avançada (indústria de base de metal-mecânica e química). A política econômica nesse período enfatizou o Estado como atuante direto na economia, como protetor das empresas nacionais e produtor de desenvolvimento industrial.

Este período que havia começado com o crescimento acelerado da economia, passou na sequencia por sucessivas crises. No início dos anos de 1970, houve uma desaceleração que se prolongou por outras décadas (CIDADE; VARGAS, JATOBÁ, 2008, p.29). A crise da dívida externa brasileira no início dos anos 1980, de acordo com Fiori (apud Cidade et al 2008, p. 29) encerrou o período desenvolvimentista e deu origem a uma fase neoliberal.

As políticas econômicas neste período acirraram o endividamento do país, promovendo elevação dos índices inflacionários e consequentemente a diminuição do poder aquisitivo da população. Ao mesmo tempo essas políticas enfatizavam investimentos maciços em alguns pontos do território e setores da economia.

Os anos 1980 foram marcados por inúmeras tentativas de estabilização econômica como os Planos Cruzado I e II (1986) e o Plano Bresser (1987). Estes planos acabaram diminuindo o desenvolvimento industrial, pois a constante instabilidade econômica afastava os investimentos. No final da década de 1980, o Plano Collor pois representou a opção por uma alternativa de um alto custo e reduzidas chances de compatibilizar crescimento econômico com preços acessíveis. Nos anos 1990, o Plano Collor como foi executado tornou a contenção do déficit o centro da política de desenvolvimento para a evolução futura da economia (CYSNE, 1990, p.721).

Em meados de 1990, tentou-se a estruturação de um sistema produtivo moderno e competitivo, orientado pelo mercado, dinamicamente inserido na economia internacional e capaz de expandir-se. Este sistema previa a reestruturação de segmentos industriais com problemas de competitividade ${ }^{44}$, com o apoio financeiro a projetos de fusão e políticas para apoiar a infraestrutura tecnológica e ao mesmo tempo fortalecer as microempresas. Houve ainda uma ênfase na industrialização regional, com estímulo ao surgimento de novos polos e a consolidação dos já existentes.

44 A teoria clássica da competitividade foi desenvolvida por Porter (apud PINTO, 1996, p.74) enfoca um novo paradigma em que as empresas tem que ter uma gestão estratégica de desenvolvimento e competição constante preocupação com a qualidade aliada a preços competitivos no mercado global. 
Para Tavares (1993, p.2), este sistema produtivo competitivo visava obter o máximo de flexibilidade em relação à produção, desenhos e produtos e ocupação de força de trabalho. As indústrias procuravam instalar-se em espaços que reuniam as características necessárias à acumulação flexível. O Estado brasileiro dispensou tratamento diferenciado às distintas áreas produtoras, priorizando a inversão de recursos e a implantação de infraestrutura em áreas em que existiam condições privilegiadas em relação às demais regiões, consolidando uma divisão nacional do trabalho. A inclusão ou exclusão de determinados espaços na gestão estatal, expressava a internalização de necessidades externas determinadas pelo regime de acumulação flexível (BERNADES, 1995, p.258).

A implantação do Plano Real em 1994 tinha como meta reduzir as taxas inflacionárias. O Plano Real provocou a imediata queda da inflação, propiciando a aceleração do crescimento econômico e a alta nos rendimentos. Em 1995, os aspectos favoráveis deste plano no período de estabilidade atingiram a base da pirâmide de rendimentos ocasionando retração nos índices de concentração das remunerações. A década de 1990, de acordo com o Instituto Brasileiro de Geografia e Estatística (IBGE), obteve um crescimento econômico de $24,8 \%$, ou seja, uma média anual de $2,5 \%$ ao ano (IBGE, 2010).

Com isso, o desenvolvimento industrial brasileiro manteve como elemento dinâmico um perfil de demanda que enfraqueceu o processo de difusão tecnológica em benefício da diversificação produtiva. Essa opção contribuiu para diminuir as taxas de crescimento verificadas no início do processo, estabelecendo um sistema industrial com elevado grau de integração. Este período marca a tentativa governamental de estruturar o sistema produtivo brasileiro, tornando-o mais moderno e orientado para a acumulação flexível. Os diversos planos visavam a estabilização econômica e ao mesmo tempo o desenvolvimento coordenado das atividades produtivas no território brasileiro.

\subsection{Ações de gestão no território brasileiro até o início dos anos 1990}

As ações de gestão no território brasileiro neste período buscaram de acordo com Goldenstein (1994, p.38) conciliar estabilização econômica com o desenvolvimento econômico. O projeto geopolítico de ordenamento do território nacional se consolidou nos Planos Nacionais de Desenvolvimento I e II (1975-1979) que corresponderam a uma ação rápida e combinada para, simultaneamente, completar a ocupação do território, incorporando o Centro-Oeste e a Região Amazônica. O objetivo era modernizar e expandir

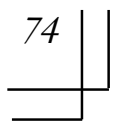


a economia nacional articulando-a a internacional e estendendo o controle do Estado a todas as atividades e a todos os lugares. Como nos períodos anteriores a integração do território foi usada como recurso simbólico para a construção do Grande Brasil e, isso significou a legitimação do Estado.

Essas políticas privilegiaram o crescimento industrial sustentado pela urbanização intensa e permanente. A urbanização do território tornou-se, então, uma estratégia para o desenvolvimento do país. No II PND houve uma ruptura de duas perspectivas: a organização interna das cidades e a rede urbana, pois era necessário promover a urbanização para a rápida modernização do país (BECKER; EGLER, 1994, p.198).

Este período foi marcado por planos setoriais de grandes investimentos em capital fixo, representados por projetos hidroelétricos, aeroportos, barragens, usinas, portos, para a expansão do sistema de transporte terrestre, marítimo e aéreo, dos meios de comunicação, das redes de energia, de oleodutos, de canais de irrigação que cortaram o país em todas as direções. Isso significaria a expansão das redes de articulação territorial, isto é, da urbanização no seu sentido mais amplo. Essa estratégia apareceu explicitamente no planejamento oficial com a criação da CNDU - Comissão Nacional de Desenvolvimento Urbano (BAER, 1986, p.406).

No início dos anos de 1980, a estratégia governamental tornou-se mais seletiva, atuando não mais numa escala macrorregional e sim sub-regional, através da implantação de parques tecnológicos para organização do território proposta pelo Estado autoritário, uma vez que envolvia a criação de locais privilegiados, capazes de interligar os circuitos nacionais e internacionais aos fluxos financeiros e de mercadorias (BECKER; EGLER, 1994, p.202).

Neste contexto, a cidade de São Paulo é ao mesmo tempo e lugar, centro de gestão e acumulação de capital e o núcleo de comando de uma vasta rede urbana que conecta a multiplicidade de espaços e tempos que compõem o território. A expansão territorial pela urbanização foi vista em relação à questão regional no Nordeste, na configuração de uma imensa fronteira e na confirmação de um vasto complexo urbanoindustrial a partir do centro dinâmico do Sudeste.

A necessidade de inserção do Brasil no regime de acumulação flexível acentuou as desigualdades regionais no Brasil, pois a atividade estatal pretendia apenas aumentar os fluxos do capital, sem diminuir a concentração industrial, nem mesmo distribuir de forma mais equitativa as taxas de urbanização. Assim a sua escala de 
desenvolvimento esteve associada ao alto grau de polarização da metrópole paulista no Sudeste (BECKER; EGLER, 1994, p.298).

O Estado atuou como mediador dos interesses externos, adequando-os as características internas. Com base nestes interesses externos adotou-se uma estratégia de de gestão do território com vistas a adequar o espaço, de modo que assegurasse a transferência geográfica do valor a nível internacional, como consequência direta do regime de acumulação flexível (BERNADES, 1995, p. 257). Assim, o Estado passou a agir como regulador das diversas atividades econômicas de forma a assegurar a maior fluidez do capital no território brasileiro.

A organização espacial das redes de circulação de mercadorias, distribuição de energia elétrica e de telecomunicações foram indicadores dos efeitos do processo de modernização industrial sobre o território brasileiro, na medida em que foram transformadas estruturas espaciais anteriores e construídas novas formas adequadas, aos processos de produção e gestão de complexos industriais.

O processo de ocupação territorial brasileiro no final dos anos de 1980 do foi marcado por uma enorme desigualdade entre as regiões, especificamente diversas atividades econômicas esparsas e pouco articuladas entre si, com um eixo polarizador nas regiões sul-sudeste do país e uma intensa recessão econômica, proveniente dos gastos públicos que impulsionaram o desenvolvimento industrial do país nas décadas anteriores.

Essa situação apenas repetiu a dinâmica do desenvolvimento capitalista geograficamente desigual, pois a ideia é que o processo ocorra de forma heterogênea, produzindo desigualdades espaciais e continuamente vantagens à entrada de capital e investimentos. Soja (1993, p.132) argumenta que o regime de acumulação baseia-se intrinsecamente nas desigualdades regionais ou territoriais, como meio necessário de sua sobrevivência contínua. A própria existência da acumulação pressupõe a presença mantenedora e a instrumentalidade vital do desenvolvimento geograficamente desigual.

Assim, rede de circulação de mercadorias, expressa na malha rodoviária nacional, delimitou a área de mercado integrada, produzindo desigualdades territoriais. A rede de energia impõe-se à área industrial central, o Sudeste, mostrando a capacidade da atividade produtiva de construir sua base técnica territorial que, no caso específico da rede de distribuição de energia elétrica, foi montada nos últimos trinta anos com maciço investimento estatal. A rede nacional de telecomunicações evidenciou que os maiores aglomerados urbanos estavam interligados no que diz respeito à circulação rápida de informações a longa distância. 
Com isso, o território nacional configurou-se numa imbricada superposição no qual o conjunto de centros urbanos esteve ligado por redes hierarquizadas que demonstravam as relações e atividades econômicas entre centros e periferias (BECKER, 1994, p.197-8). Neste sentido, São Paulo, a maior metrópole nacional elevou essas redes hierarquizadas para além desta superposição com um processo de urbanização que produziu uma aglomeração difusa que cornubou diversas cidades e se expandiu por vários quilômetros no território paulista (LENCIONI, 2008, p. 7).

O desenvolvimento dessas redes hierarquizadas acentuou o grau de desigualdade regional devido ao aumento da concentração das atividades produtivas nas regiões metropolitanas, mantendo o eixo polarizador nas regiões Sudeste e Sul do país. Assim, o desenvolvimento regional neste período pode ser denominado desigual e combinado $^{45}$, porque manteve as mesmas regiões com melhores benefícios e ainda manteve aquelas que interessavam diretamente ao processo de acumulação flexível.

As décadas de 1970 e 1980 foram marcadas por intenso processo de urbanização. Todavia, as dinâmicas regionais e urbanas oriundas deste processo acirraram a concentração populacional em um conjunto limitado de metrópoles, como uma rede urbana concentrada e estruturada nas regiões Sudeste e Sul. Em contraposição a esta concentração territorial permaneceram os núcleos populacionais rarefeitos nas regiões Centro-Oeste e Norte. A região Nordeste apresentou concentração populacional, mas com uma rede urbana descontínua e não estruturada.

Este período foi marcado pela urbanização extensiva que significou a ampliação da influência das cidades sobre o meio rural, eliminando a separação entre cidade e o campo. O meio rural além da perda de contingente populacional neste período ainda se submeteu às condições de produção e consumo das cidades.

De acordo com Diniz; Crocco (2006, p. 26) a ampliação do alcance das cidades, levou a um processo irreversível de concentração nas metrópoles nacionais e da centralidade urbana. Assim, as políticas de planejamento e desenvolvimento regional, no início dos anos de 1990, estiveram voltadas para a compreensão da rede urbana e de seu papel na estruturação e organização do território brasileiro.

Neste contexto das grandes metrópoles nacionais, a cidade de São Paulo continuou a estender sua centralidade urbana, reafirmando seu papel de metrópole concentrada. Assim, a região Sudeste com sua metrópole manteve a área core e o núcleo

\footnotetext{
${ }^{45}$ Este argumento é defendido por BECKER; EGLER (1994).
} 
polarizador aumentando as disparidades regionais no território brasileiro, resultando em um movimento de reconcentração das atividades produtivas nas regiões Sul e Sudeste.

\subsection{Cenário produtivo brasileiro a partir do final dos anos 1990}

Considerando as fases estabelecidas por Diniz; Crocco (2006, p. 14) este período é marcado pelo novo desenvolvimentismo ou uma fase pós-liberal. Autores como Diniz; Crocco (2006) e Bresser-Pereira (2006) consideram o novo desenvolvimentismo como uma estratégia nacional de desenvolvimento e não uma teoria econômica, um outro discurso entre o populista e a ortodoxia convencional (neoliberalismo), e também entre o neoliberalismo de direita e o estatismo da esquerda mais radical.

De acordo com Bresser-Pereira (2006) o novo desenvolvimentismo preconiza medidas que não rejeitam totalmente a acumulação flexível, mas pressupõe o controle da taxa de juros a curto prazo; o aumento da poupança interna; a necessidade de uma coesão nacional; a incorporação das inovações sem contudo, aumentar o desemprego; o controle do endividamento externo e interno e; o aumento da poupança interna.

No governo de Fernando Henrique Cardoso (1995-1998) foram definidos pontos fundamentais para a política industrial brasileira: o aumento do nível de investimentos; a aceleração da capacitação tecnológica e aprofundamento das reformas institucionais (privatizações) e; a modernização da administração pública. No ano de 1996, diante da implantação das políticas de privatização ${ }^{46}$ de ativos federais e estaduais, alguns setores específicos apresentaram estabilidade e crescimento como os de petróleo, gás, telecomunicações e tecnologia da informação.

Este período foi marcado pela estagnação decorrente da crise da dívida externa e da instabilidade econômica. Houve a abertura comercial e consequentemente um aumento dos Investimentos Diretos Estrangeiros (IDEs). Cidade (1999), aponta que a economia nesse período ficou limitada aos setores da economia mantidos por IDEs, levando ao fracasso dessa estratégia, pois o crescimento da demanda para induzir as etapas mais avançadas da industrialização era insuficiente.

O principal objetivo dessa política industrial era a consolidação do padrão de expansão do sistema industrial brasileiro, a partir da criação de condições para que as empresas passassem à etapa centrada no crescimento da capacidade de produção e

\footnotetext{
46 Foram privatizadas inúmeras empresas públicas, dentre elas a Vale do Rio Doce, em 1997 e a Telebrás em 1998.
} 
inovação. Essa fase é denominada de etapa de reestruturação e expansão competitiva do sistema industrial brasileiro (PINTO, 1996, p.101).

Os princípios básicos estabelecidos de política industrial e tecnológica neste período preconizavam a conformação de um ambiente favorável ao investimento e ao aumento da competitividade das empresas, com a estabilidade econômica, a modernização das relações trabalhistas e atuação governamental na identificação e na promoção das oportunidades de investimentos estrangeiros.

O Brasil do início do século XXI é marcado por sua maciça inserção na na acumulação flexível. De acordo com Penna (2012, p. 113), ocorreu a organização de setores produtivos modernos e de tecnologias de informação e comunicação de ponta com alto padrão salarial e ao mesmo tempo a flexibilização e informalidades dos mercados. A política industrial estatal procurou aumentar o processo de capacitação de inovação e infraestrutura tecnológica, o investimento em pesquisa e desenvolvimento pelo setor produtivo e a orientação governamental para aplicação dos recursos e dos estímulos existentes em inovações.

No ano de 2001, houve um crescimento do Produto Interno Bruto (PIB) da ordem de 3,84\%, em comparação com o ano de 1999. De acordo com dados do IBGE (2010), a agropecuária cresceu $6,45 \%$, a indústria $5 \%$, sendo o setor de serviços o com menor dinamismo, apenas 2,96\%. Em função das significativas mudanças na economia, houve um aumento no consumo de bens duráveis. As políticas de desregulamentação e privatização e a estabilidade macroeconômica impulsionadas pelas fusões e aquisições de empresas acumularam fluxo expressivo de IDEs no Brasil em torno de U\$ 32,8 bilhões de dólares no ano 2001.

Em 2003, no Governo Luís Inácio Lula da Silva (2003-2010) a política externa brasileira passou a enfatizar as exportações, privilegiando mercados do mundo em desenvolvimento com a venda de produtos manufaturados de maior valor agregado, como autopeças, aviões, bens de capital, eletroeletrônicos que alcançaram em 2005, 55,1\% do total de exportações. Essa política amplamente identificada no modelo neoliberal serviu com uma forma de ajuste fiscal e como forma de estabelecer melhor relação com os seguimentos de mercado para atrair investimentos.

Esse período foi marcado pelo novo desenvolvimentismo, caracterizado pela extrema elevação das taxas de juros em curto prazo; aumento das taxas de investimentos, principalmente IDEs e o controle do endividamento interno e externo. Essas medidas visavam a redução do desemprego e da concentração de renda e, acreditava-se na 
diminuição das disparidades regionais numa tentativa de integração dos mercados regionais.

O ano de 2006 foi considerado um ano de grande crescimento uma vez que a economia brasileira experimentou um superávit comercial jamais visto permitindo a redução da vulnerabilidade externa. As políticas públicas contidas no Programa de Aceleração do Crescimento - PAC (2007-2010), foram marcos estratégicos orientadores de ações estruturantes, contendo medidas voltadas para a expansão da economia e a elevação dos investimentos em infraestrutura contribuindo para o crescimento econômico neste período.

Como resultado houve o aumento da confiança na economia brasileira, sendo que em 2008, o volume de investimento no exterior somou US\$ 34 bilhões. Essa internacionalização de grandes empresas nacionais facilitou a atualização tecnológica, novas colocações em mercados dinâmicos e o acesso a fontes externas de financiamentos conforme o Instituto de Pesquisa Econômica Aplicada - IPEA (2010, p.14).

No ano de 2011, houve um crescimento de 2,7\% do PIB brasileiro em relação ao ano anterior, impulsionado pelas expansões de $2,5 \%$ no valor adicionado bruto e de 4,3\% nos impostos sobre produtos líquidos e subsídios. Quanto aos setores econômicos, a agricultura apresentou crescimento de $3,9 \%$, a indústria, $1,6 \%$ e o setor de serviços, $2,7 \%$, que apresentou variações positivas em todas as suas atividades com destaque para os serviços de informação da ordem de $4,9 \%{ }^{47}$.

Este mesmo crescimento se manteve ainda nos três anos subsequentes. A partir do segundo mandato da presidente Dilma Roussef, iniciado em 2014, o cenário aumentou uma tendência adversa que já se instalava anteriormente. Mesmo mantendo as políticas de incentivo à produção interna, o combate miséria, as desonerações fiscais, a diminuição dos gastos públicos, visando estimular o consumo, o governo atual não tem conseguido contornar os efeitos da crise econômica.

Como consequência da política de ajuste fiscal própria do modelo neoliberal o governo atual não tem conseguido impedir os impactos da crise econômica no país. Segundo dados do IBGE (2015) o PIB trimestral verificado nos meses de julho a setembro de 2015 retraiu 1,7\% frente ao segundo trimestre (abril a junho) e 4,5\% frente ao mesmo período de 2014. Na comparação com outros valores de anos anteriores, trata-se da pior

\footnotetext{
${ }^{47}$ Companhia de Planejamento do Distrito Federal - CODEPLAN (2013).
} 
queda desde o início da série histórica do órgão, em 1996, deixando evidenciada a recessão econômica que assola o país.

O ajuste fiscal considerado tardio pelos especialistas adotado pelo governo atual contribuiu para o aprofundamento da recessão. A problemática é que em tempos de crise econômica controlada com ajuste fiscal mais rígido, existe uma queda da arrecadação e com isso o aumento do déficit fiscal. De acordo com último relatório de receitas e despesas (MPOG, 2015) o Governo Federal reduziu a meta fiscal de 2015 para um déficit primário de 51,8 bilhões de reais, ou seja, 0,8 do PIB, evidenciando que o ajuste fiscal preconizado não foi eficiente nem para produzir o superávit, muito menos permitir o crescimento do PIB no período.

As forças de concentração que correspondem aos requisitos locacionais da acumulação flexível; a necessidade de proximidade de recursos humanos qualificados; os mercados consumidores de alta renda e; a infraestrutura estão cada vez mais presentes nas áreas metropolitanas. De acordo com Araújo (2000, p. 118) o período é marcado por forças de concentração das atividades e ao mesmo tempo por forças de desconcentração que são a abertura comercial, as mudanças tecnológicas, as considerações logísticas, a proximidade do mercado consumidor e os incentivos estatais.

O setor de serviços, de acordo com Azzoni (2005, p. 570) é o segmento mais dinâmico, evidencia o desempenho significativamente favorável da Região Sudeste. As políticas industriais nesse período contribuíram para a formação de uma nova regionalização territorial de distribuição espacial das atividades dividida em quatro eixos principais, o polígono industrial, o complexo agroindustrial, agroindústria, industrial de bens não duráveis e a biotecnologia.

O cenário atual de recessão econômica brasileira demonstra que mesmo diante de políticas fiscais de ajuste contracionistas o governo não tem conseguido impedir ao aumento das taxas de juros e inflação. Com isso, tem ocorrido a retração dos investimentos, a desaceleração industrial, a diminuição do consumo das famílias e o aumento do desemprego. A diminuição dos investimentos internos ou externos tem provocado a desaceleração industrial e uma nova adequação da estrutura industrial, como a redução da produção e as demissões para corte de gastos no âmbito das organizações. 


\subsection{Dispersão urbana a partir do final dos anos 1990}

A ocupação territorial brasileira neste período foi caracterizada por um processo de urbanização disperso em torno das várias regiões metropolitanas, como São Paulo e Belo Horizonte. Assim, as desigualdades na distribuição e concentração da renda, refletiram o crescimento e a ampliação das áreas periféricas. $\mathrm{O}$ enfraquecimento do Estado numa perspectiva neoliberal foi reduzindo a atuação estatal no âmbito de diversos órgãos como as superintendências de desenvolvimento regional. Assim, o período se caracteriza pela ausência de planos nacionais de desenvolvimento regional. Somente no Governo Fernando Henrique Cardoso (FHC) (1995-2002) no programa de governo intitulado Avança Brasil que o desenvolvimento regional foi tratado, mas associado à infraestrutura.

Com a criação do Ministério da Integração Nacional no Governo FHC, regulamentou em 2007 a Política Nacional de Desenvolvimento Regional (PNDR) que tinha como meta a redução das desigualdades regionais. O documento procurou estabelecer estratégias em escalas macro e microrregional. Adotando como foco as mesorregiões, criou programas específicos também para o semiárido, a faixa de fronteiras e as regiões integradas de desenvolvimento.

Neste período o desenvolvimento regional esteve associado ao processo de desconcentração industrial numa tentativa de determinar as atividades econômicas. Assim, o Governo incentivou uma guerra fiscal entre os Estados para que novos investimentos se deslocassem dos centros tradicionais e polarizadores, para localidades que ofereciam vantagens e incentivos fiscais atraentes ao IDEs.

Destaca-se nesse período seguindo a previsão da Carta Magna de 1988, em termos de política urbana a obrigatoriedade de Plano Diretor para os municípios com mais de vinte mil habitantes. Este instrumento de planejamento urbano foi fundamental para a elaboração do Estatuto das Cidades que regulamentou os critérios de gestão urbana e territorial.

No governo Luís Inácio Lula da Silva (2003-2010) a criação do Ministério das Cidades foi a principal sinalização da importância que a política urbana nas últimas décadas. Dessa forma, as políticas urbanas desse período estiveram também associadas ao crescimento econômico. Cumpre destacar que houve um incentivo ao desenvolvimento de áreas da região nordeste, investimento em ferrovias, criação de empresas estatais de desenvolvimento e a retomada das superintendências de desenvolvimento regional. De acordo com Cidade et al. (2008, p. 21) no Plano Plurianual - PPA 2004/2007 (Brasil de 
Todos) foram incluídos programas para o desenvolvimento territorial e também programas sociais como o Bolsa Família que tinha como objetivo diminuir as desigualdades sociais e regionais e seus efeitos.

Houve o agravamento das desigualdades regionais devido ao aumento da concentração das atividades produtivas nas regiões metropolitanas, sobretudo na Região Sudeste. O território metropolitano neste período reflete a concentração e desigualdades regionais. A região Sudeste e, notadamente, São Paulo continua a ser o centro polarizador. Neste contexto, a área core ou metrópole concentrada continua a estender sua centralidade.

Dessa forma, o movimento de urbanização gerou também movimentos de reorganização e fragmentação do tecido urbano. Surgem áreas que podem ser extensões dos tecidos metropolitanos concentradores ou até mesmo expansões periféricas dos núcleos centrais. A inserção brasileira na acumulação flexível inaugurou uma nova ordem urbana, com movimentos de fragmentação e reorganização urbana. Para Lacerda (2000, 2011) existe um movimento de reorganização produtiva, que não cancelou a estrutura preexistente, mas que ora se sobrepõe, ora se justapõe, num movimento de fragmentação territorial e simultaneamente, de integração territorial.

Os núcleos tradicionais metropolitanos continuam a exercer sua força concentradora sobre o território, recebendo incentivos maiores às atividades econômicas que interessam à acumulação flexível. O movimento de urbanização dispersa tem provocado o surgimento de novas centralidades, sobretudo nas regiões Centro-Oeste e Norte. No entanto, essas movimentações não se assemelham ao intenso processo verificado nas regiões Sul e Sudeste.

De acordo com Limonad (2006, p.39) mesmo com a hesitação dos conservadores, não se pode mais pensar as áreas urbanas como um conjunto delimitado de áreas concentradas, muito menos como polígono fechado e contido dentro de um perímetro administrativo e politicamente destinado ao teste prático de experiências consagradas de planejamento adequadas a cidades e espaços de outros tempos. A tendência é uma extensificação da urbanização além dos limites do marco construído da cidade. Mesmo diante de políticas de desenvolvimento regional e a retomada das superintendências regionais de desenvolvimento e dos movimentos de dispersão/fragmentação urbana, existe uma tendência de reconcentração urbana e das atividades nas regiões Sudeste e Sul da mesma forma dos períodos anteriores.

Essa extensificação denominada por Limonad (2006, p.39) de urbanização dispersa provoca a expansão de centros de serviços, inclusive parques industriais, podendo 
ser implantadas próximo de rodovias e/ou vias de circulação rápida. Esse movimento de dispersão e reorganização toma por base a produção imposta pela acumulação flexível gerando formas no território usado como os parques tecnológicos.

\subsection{Experiências brasileiras com parques tecnológicos}

As experiências com parques tecnológicos no mundo surgiram para atender as necessidades específicas das empresas inovadoras e romperam com a forma de produção fordista, pois as inovações propiciaram a flexibilização da produção e das relações entre as empresas inserindo-as no regime de acumulação flexível.

No Brasil, os parques tecnológicos surgiram em um primeiro momento como alternativas de crescimento econômico regional/local. Em um segundo momento passaram a produzir inovações que contribuíram para o avanço do setor terciário. $\mathrm{Na}$ atualidade os parques têm produzido inovações que reafirmam a tendência do setor terciário para um terciário avançado ${ }^{48}$.

Segundo a Associação Nacional de Entidades Promotoras de Empreendimentos Inovadores - ANPROTEC (2015) os parques tecnológicos constituem complexos produtivos industriais e de serviços que se fundam na associação de conhecimentos científicos e tecnológicos, planejados, de caráter formal, cooperativo e concentrado.

Nos anos de 1970 houve investimentos estatais no setor tecnológico, ocasionando uma concentração de empresas próximas de universidades. Esse quadro foi observado principalmente na região Sudeste do país criando condições para a formação de parques tecnológicos ${ }^{49}$. As primeiras iniciativas de implementação de parques tecnológicos no Brasil surgiram nos anos de 1980. Estas iniciativas surgiram no contexto de crise que o país atravessava devido a dívida externa.

O Estado neste período passou a atuar dinamicamente na área energética e de ciência e tecnologia, administrando a disputa do poder por parte dos distintos grupos através da concessão de crédito. Dessa forma, é relevante a compreensão dos interesses dos atores $^{50}$ que atuavam sobre o Estado e que efetivamente organizavam o seu papel público, principalmente no tocante à aquisição de tecnologia articulada à política econômica, e de

${ }^{48}$ O terciário avançado é uma nomenclatura desenvolvida por autores como Sassen (1998); Taylor (2001). O IBGE também adota esta terminologia para os serviços mais especializados e tecnologizados.

${ }^{49}$ Neste primeiro momento, estes ainda eram polos ainda muito ligados ao desenvolvimento de fatores de industrial do que inovações no sentido estrito.

${ }^{50}$ Esses interesses, intencionalidades serão discutidos no Capítulo 06. 
como essa articulação dinâmica do mercado externo gerava pressões sobre o Estado brasileiro para renovar e adequar, o que correspondia a um determinado nível de exigência de amortização das inovações na escala internacional (BERNADES, 1995, p. 257).

As articulações entre pesquisa e desenvolvimento estiveram presentes desde os projetos militares do início do século passado (entre guerras), todavia a efetividade da estruturação ou a elaboração de parques tecnológicos no Brasil passou a ser delimitado a partir da década de 1980, assumindo um papel de instrumento para reduzir a lacuna tecnológica entre o país e a dinâmica mundial (LIMA, 1991, p.5).

Estes parques tecnológicos foram resultado da alta concentração das atividades produtivas, nas grandes metrópoles, funcionando como princípio do projeto geopolítico formado no corredor metropolitano entre Rio e São Paulo. De acordo com Lima (1993) foram conjugados aos interesses militares / civis e públicos/ privados, ora em forma de parques tecnológicos, ora em núcleos tradicionais, ou seja, complexos industriais.

Estes parques iniciais buscavam ligações entre a pesquisa e o processo produtivo. Para avançar nesta discussão precisamos reconhecer a necessidade de algumas condições que propiciem estas ligações que são a presença de universidades, centros de pesquisa e serviços específicos destinados as empresas inovadoras ${ }^{51}$.

Neste sentido destaca Lencioni (2007, p. 09) que as atividades de inovação ${ }^{52}$ exigem uma disponibilidade de recursos, equipamentos relacionados ao trabalho e uma certa densidade de profissionais qualificados. É justamente pela presença destes profissionais que a autora justifica a importância das universidades e dos centros de pesquisa. O desenvolvimento de inovações envolve diversas atividades científicas e tecnológicas exigindo investimentos estatais e das empresas inovadoras e dos centros de pesquisas.

Para Lencioni (2007, p. 09) a localização desses parques tecnológicos no território brasileiro está associada à disponibilidade das condições acima mencionadas, portanto, se há uma desigual distribuição destas, há também uma distribuição territorial desigual dos parques tecnológicos.

Esta distribuição esteve associada as políticas de fomento a Ciência e Tecnologia. Dentre elas, o Programa de Apoio ao desenvolvimento Científico e Tecnológico (PADCT) (1985-1990) que tentou ampliar e consolidar nas universidades,

\footnotetext{
51 Estas condições foram apresentadas no Capitulo 03. Ver item 3.1.

52 A autora utiliza os termos tecnologias de ponta, atividades de ponta ou alta tecnologia. Para fins de correspondência com outras ideias já apresentadas, vamos manter o termo inovações.
} 
centros de pesquisas e empresas as atividades de pesquisa e desenvolvimento. O III PADCT (1998-2004) com financiamentos do Banco Mundial tinha como meta o aperfeiçoamento da infraestrutura científica.

No Quadro 4.1 apresentamos os principais programas de incentivo à Ciência e Tecnologia no país com as metas e os objetivos dos programas o III Plano Básico de Desenvolvimento Científico e Tecnológico (PBDCT) - 1980/1985. Também o Programa de Apoio ao Desenvolvimento Científico e Tecnológico (PADCT) - 1984; o Programa de Apoio à Capacitação Tecnológica da Indústria (PACTI) - 1990 e a Política Brasileira de Ciência e Tecnologia (PBCT) - 1990/1995 e; o III Programa de Apoio ao desenvolvimento Científico e Tecnológico (III PADCT) - 1998/2004.

Quadro 4.1 Políticas de Ciência e Tecnologia (1980-2004)

\begin{tabular}{|c|c|c|}
\hline Política & Metas & Objetivos \\
\hline $\begin{array}{c}\text { III - PBDCT } \\
(1980-1985)\end{array}$ & $\begin{array}{l}\text { Diminuir a dependência de C\&T } \\
\text { brasileira. }\end{array}$ & $\begin{array}{l}\text { Aumentar o grau de autonomia } \\
\text { tecnológica industrial através do } \\
\text { fortalecimento da capacidade de geração } \\
\text { e absorção de tecnologias das empresas } \\
\text { nacionais. }\end{array}$ \\
\hline $\begin{array}{c}\text { PADCT } \\
\text { (1984) }\end{array}$ & $\begin{array}{l}\text { Sustentar o desenvolvimento dos } \\
\text { setores prioritários de C \& T. }\end{array}$ & $\begin{array}{l}\text { Atuar prioritariamente nos seguintes } \\
\text { setores: educação, biotecnologia química, } \\
\text { geociência, tecnologia mineral } \\
\text { informação em C\&T. }\end{array}$ \\
\hline $\begin{array}{r}\text { PACTI } \\
(1990)\end{array}$ & $\begin{array}{l}\text { Apoiar a capacitação tecnológica da } \\
\text { indústria através das entidades do } \\
\text { governo (federal, estadual e } \\
\text { municipal) e suas agências } \\
\text { financiadoras. }\end{array}$ & $\begin{array}{l}\text { Promover a formação e desenvolvimento } \\
\text { de recursos humanos: modernização e } \\
\text { infraestrutura de C \& T; } \\
\text { Fortalecer e intensificar a articulação e } \\
\text { cooperação entre governo, indústria e } \\
\text { universidade; } \\
\begin{array}{l}\text { Alocar recursos aos institutos, } \\
\text { universidades e escolas. }\end{array}\end{array}$ \\
\hline $\begin{array}{c}\text { РBCT } \\
(1990-1995)\end{array}$ & $\begin{array}{l}\text { Consolidar a base técnico-científica } \\
\text { brasileira; } \\
\text { Contribuir para a } \\
\text { problemas solução dos } \\
\text { setoriais do país. }\end{array}$ & $\begin{array}{l}\text { Estimular a qualificação de recursos } \\
\text { humanos dos institutos de P\&D; } \\
\text { Recuperar e atualizar a infraestrutura } \\
\text { nacional de C\&T; } \\
\text { Promover articulação entre empresas e } \\
\text { universidades de P\&D. }\end{array}$ \\
\hline $\begin{array}{l}\text { III PADCT } \\
(1998 \text { - 2004) }\end{array}$ & Aperfeiçoamento do setor de C\&T & $\begin{array}{l}\text { Formação de mão de obra qualificada; } \\
\text { Aperfeiçoamento de infraestrutura de } \\
\text { C\&T. }\end{array}$ \\
\hline
\end{tabular}

Fonte: CNPq, 2015.

O Quadro 4.1 mostra que estas políticas guardam semelhanças no que diz respeito ao desenvolvimento tecnológico e industrial no sentido de estimularem a ciência e 
a tecnologia. Importante ressaltar que o PBCT - 1990/1995 teve como meta contribuir para a solução dos problemas regionais e setoriais do país.

Além dos programas foram também estabelecidas legislações para o apoio às políticas industriais e tecnológicas no Brasil, buscando aumentar e fortalecer a formação de parcerias e a integração entre as universidades, instituições de C\&T. Houve ainda, um estímulo à construção de espaços especializados de cooperação, apoiados por agências de fomentos à inovação, dentre eles, os parques tecnológicos.

Do ponto de vista das ações de ciência e tecnologia, além dos investimentos financeiros em relação ao PIB, ocorreram inúmeros avanços legais como a promulgação de leis, decretos, acordos, parcerias, incentivos fiscais através de políticas nacionais, estaduais ou municipais de C\&T. Destacam-se a Lei $n^{\circ} 10.973 / 2004$ (Lei da Inovação), a Lei ${ }^{\circ}$ 11.196/2005 (Incentivos Fiscais para a inovação tecnológica), Plano de Ação em Ciência, Tecnologia e Inovação para o Desenvolvimento Científico e Tecnológico (PACTI) 20072010 - MCT -2007, Fundo Nacional do Desenvolvimento Científico e Tecnológico (FNDCT) - MCT -2007 e a Política de Desenvolvimento Produtivo - do Ministério do Desenvolvimento da Indústria e Comércio Exterior (MDIC) -2008.

De acordo com Bermúdez (2013, p. 92) a Lei nº 10.973/2004 (Lei da Inovação) é considerada o marco legal da inovação, pois influenciou no estabelecimento de políticas industriais direcionadas a produção de novas tecnologias em setores estratégicos como softwares, semicondutores, biotecnologia, nanotecnologia e energias renováveis.

O Estado (Governo Federal), através do MCT e particularmente da FINEP, apoiou várias iniciativas distribuídas no território nacional e ainda, houve um esforço descentralizado e pontual de alguns governos estaduais para implantação de parques tecnológicos. Segundo dados da ANPROTEC (2015) existem atualmente no país, cerca de 400 incubadoras de empresas e 80 empreendimentos de parques tecnológicos nas três etapas de constituição, em operação, implantação e projeto conforme apresentado na Figura 4.1.

A Figura 4.1 mostra que existe uma concentração espacial dos parques tecnológicos nas regiões Sul e Sudeste do país, sendo possível três constatações. A primeira delas é que a maior parte dos parques tecnológicos em operação se concentram nas Regiões Sul e Sudeste, corroborando com a discussão apresentada nos tópicos iniciais deste Capítulo sobre o cenário produtivo brasileiro: coincidem com as maiores regiões 
industrializadas do país. A segunda é que as experiências internacionais ${ }^{53}$ principalmente as italianas e japonesas com parques tecnológicos se localizaram em áreas com uma industrialização prévia ou que estavam estagnadas, como no caso das indústrias paulistas. A terceira é a importância da compreensão das implicações temporais (passado-presente) de Santos (1979) para explicar as transformações no território usado. As áreas apresentadas na Figura 4.1 com os parques tecnológicos em operação coincidem com aquelas de industrialização intensiva que se iniciou no Século XX.

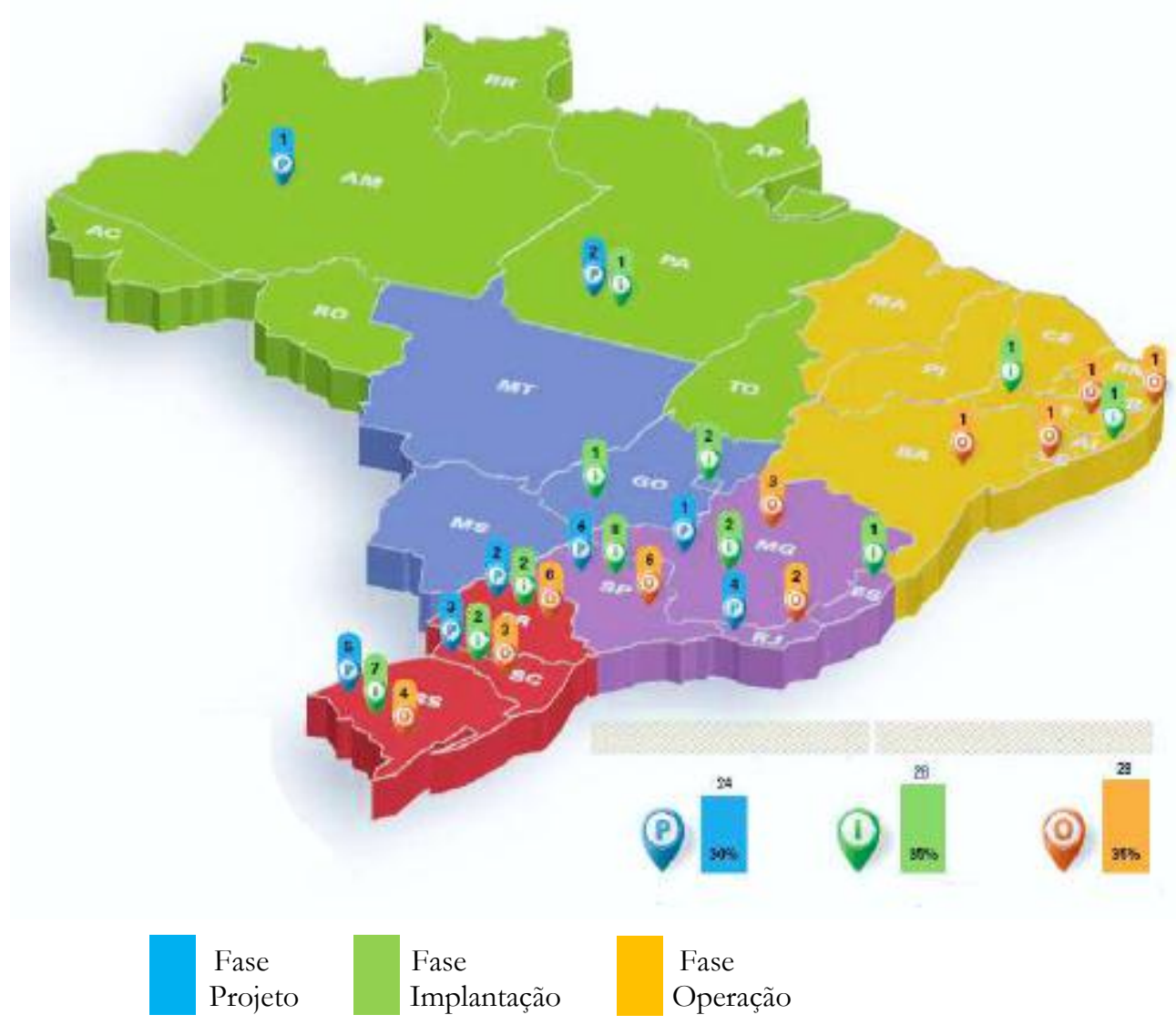

Figura 4.1 Distribuição dos parques tecnológicos por Estado - Brasil - 2013

Mostra a distribuição das iniciativas de parques tecnológicos por Estado, sendo 24 em fase de projeto, 29 em fase de implantação e outros 29 em fase de operação. Mostra o PTCD como parque tecnológico em fase de implantação. Mostra ainda, a concentração espacial dos parques tecnológicos nas regiōes Sul e Sudeste.

Fonte: ANPROTEC, 2013.

A partir da Figura 4.1 acima pode-se observar que existe maior concentração de iniciativas de parques tecnológicos nas regiões Sul e Sudeste contrastando com as

53 As experiências foram apresentadas no Capítulo 03. 
demais regiões em que as iniciativas apresentam-se reduzidas. Com exceção dos quatro parques em operação na região nordeste, todas as outras iniciativas das regiões CentroOeste, Norte e Nordeste apresentam-se em fases de implantação ou projeto.

De acordo com a ANPROTEC (2013) nos anos de 2006 a 2008 houve um aumento das iniciativas de parques tecnológicos no Brasil impulsionadas pelos avanços legais das políticas de ciência de tecnologia federais, como a Lei da Inovação e a Lei do Bem. O Gráfico 4 abaixo mostra que nos anos de 2000 a 2005 foram 15 iniciativas, nos anos de 2006 a 2008 foram 49 iniciativas com parque tecnológicos. Se comparados os dois períodos aumentaram as iniciativas em torno de $70 \%$.

Gráfico 4.1 Projetos de parques tecnológicos no Brasil (2000-2013)

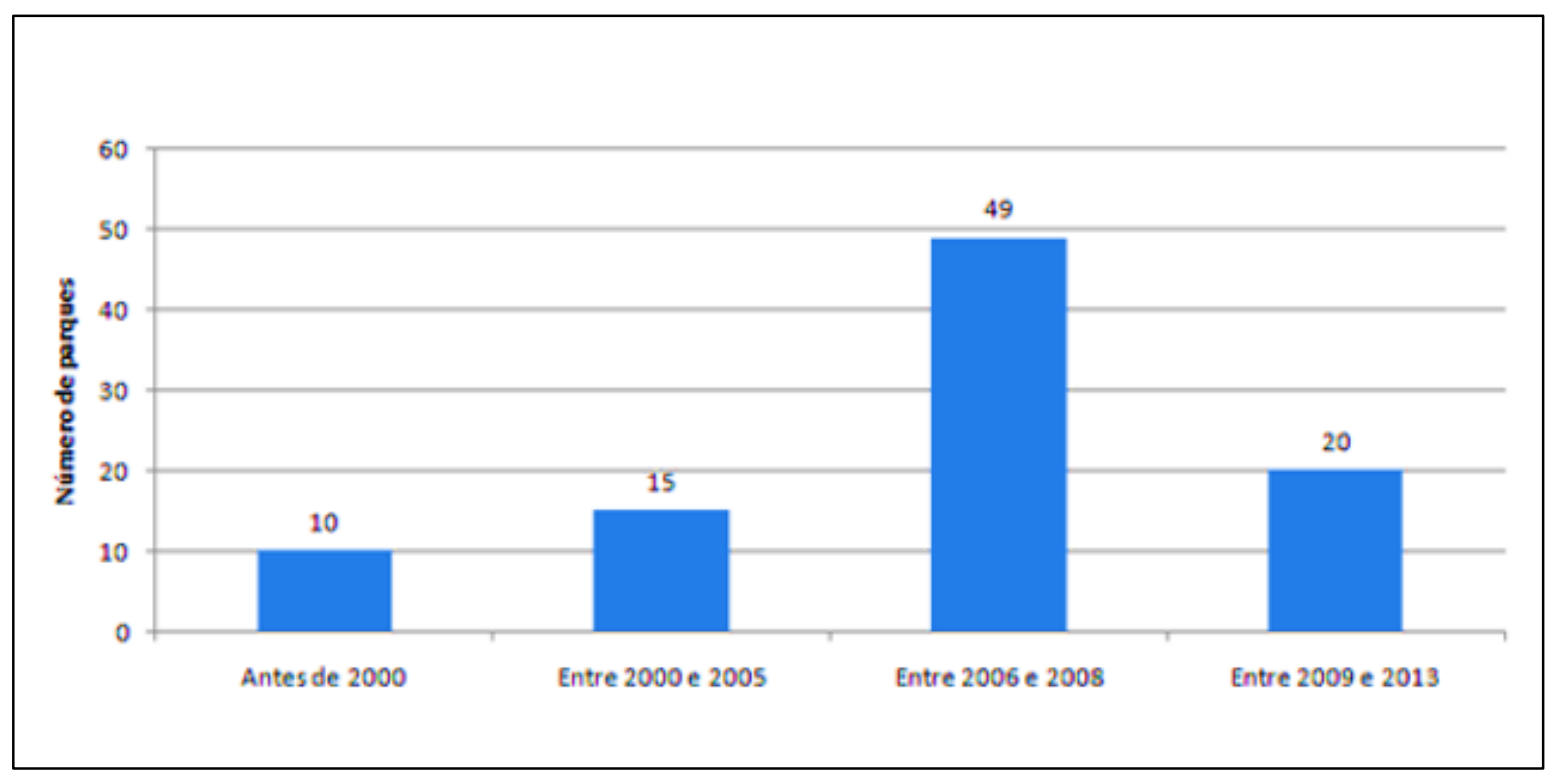

Fonte: ANPROTEC (2013)

No último levantamento divulgado pela ANPROTEC, em 2013, haviam 939 empresas instaladas nos parques tecnológicos do país com uma mão de obra de 29.909 empregos, com predomínio dos empregados com nível superior da ordem de $17.630^{54}$, os de nível médio 5.323 e de nível fundamental 544 empregados. Os dados mostram que o número de empregados com pós-graduação (6.412) é maior que o número de empregados de nível médio e fundamental que é de 5.867 empregos. Retomando as considerações de

\footnotetext{
${ }^{54}$ Destes empregados de nível superior, 2.364 são especialistas, 2.950 são mestres e 1.098 são doutores (ANPROTEC, 2015).
} 
Benko $^{55}$ (1996) e Lencioni (2008) os parques tecnológicos surgem em territórios que apresentam mão de obra altamente qualificada. Os dados acima mostram que as empresas de inovação necessitam de mão de obra qualificada superior a demanda de outros setores industriais.

O surgimento de parques tecnológicos trouxe ainda o crescimento do setor de Tecnologia da Informação e Comunicação (TIC) impulsionado por investimentos, aumento do número de empresas de inovações e do valor adicionado. A Tabela 4.1 mostra o aumento considerável da receita líquida no setor de TIC no período de 2003-2006, com um faturamento líquido de R \$205,89 bilhões. O somatório do valor adicionado com o valor de transformação industrial, ou seja, um aumento da ordem de $20 \%$ em 2006.

Tabela 4.1 Número de empresas, custo total, receita líquida e valor adicionado/valor da transformação industrial do setor de Tecnologia da Informação e Comunicação - TIC - Brasil - 2003-2006

\begin{tabular}{l|r|r|r|r}
\hline & \multicolumn{1}{|c|}{$\mathbf{2 0 0 3}$} & \multicolumn{1}{c|}{$\mathbf{2 0 0 4}$} & \multicolumn{1}{c|}{$\mathbf{2 0 0 5}$} & \multicolumn{1}{c}{$\mathbf{2 0 0 6}$} \\
\hline Número de empresas & 55.597 & 55.597 & 58.359 & 65.754 \\
\hline Custo total $^{*}$ & 153.818 .686 & 174.883 .203 & 195.290 .562 & 215.230 .776 \\
\hline Receita líquida* $^{*}$ & 139.691 .700 & 171.308 .628 & 187.191 .402 & 205.890 .414 \\
\hline $\begin{array}{l}\text { Valor Adicionado** Valor da } \\
\text { transformação industrial* }\end{array}$ & 59.412 .288 & 71.085 .785 & 74.219 .468 & 82.059 .985 \\
\hline
\end{tabular}

Fonte: adaptado de IBGE, 2006. *(1.000 R\$)

** Valor adicionado (Pesquisa Anual de Comércio, Pesquisa Anual de Serviços): é a diferença entre o valor bruto da produção e o consumo intermediário. Cálculo sem os ajustes metodológicos das Contas Nacionais que incluem a análise e tratamento dos elementos do custo intermediário e estimativas para a produção de autônomos e unidades produtivas da economia informal.

A Tabela 4.2 mostra que houve estabilidade no mesmo período no tocante à presença de empresas no setor de TIC, uma vez que sua proporção passou de 2,4\% em 2003 para 2,5\% em 2006, no que tange ao número total de empresas instaladas no Brasil. Observa-se ainda, que a receita líquida manteve participação estável na ordem de $7,1 \%$ no mesmo período.

De acordo com dados do IBGE (2006), os produtos de serviços e informática visam a promover a disponibilização dos dados, captura, tratamento qualitativo, armazenamento e disseminação compreendendo os seguintes grupos: consultoria em TIC; desenvolvimento de softwares sob encomenda; desenvolvimento, edição e licenciamento de softwares pronto para uso; suporte técnico; tratamento de dados e hospedagem de sites; manutenção e outros serviços.

55 Ver discussão no Capítulo 02. 
Tabela 4.2 Participação do setor de Tecnologia da Informação e Comunicação - TIC, no total da economia - Brasil - 2003-2006

\begin{tabular}{l|r|r|r|c}
\hline & $\mathbf{2 0 0 3}$ & $\mathbf{2 0 0 4}$ & $\mathbf{2 0 0 5}$ & $\mathbf{2 0 0 6}$ \\
\hline Número de empresas & 2,4 & 2,4 & 2,4 & 2,5 \\
\hline Custo total $^{*}$ & 7,6 & 7,5 & 7,5 & 7,5 \\
\hline Receita líquida* $^{*}$ & 7,1 & 7,3 & 7,1 & 7,1 \\
\hline $\begin{array}{l}\text { Valor Adicionado/Valor da } \\
\text { transformação industrial* }\end{array}$ & 8,9 & 9,0 & 8,4 & 8,3 \\
\hline
\end{tabular}

Fonte: adaptado de IBGE, 2006. *(1.000 R\$)

Esses produtos e serviços em geral são desenvolvidos por transferência e/ou criação de tecnologias desenvolvidas nos parques tecnológicos. A Tabela 4.3 apresenta que os serviços de tratamento de dados e hospedagem de sites também se destacam com participação expressiva no período considerado, em torno de $15,0 \%$ da receita. O comércio de produtos de informática (venda de softwares prontos para uso, computadores e seus periféricos), aparece com uma média de $18,5 \%$ do faturamento somados com outros serviços, 17,3\% em 2006.

Tabela 4.3 Participação dos produtos e serviços de informática no total da receita de serviços de informática - Brasil - 2003-2006 (\%)

\begin{tabular}{l|r|r|r|r}
\hline \multicolumn{1}{c|}{ Serviços } & $\mathbf{2 0 0 3}$ & $\mathbf{2 0 0 4}$ & $\mathbf{2 0 0 5}$ & $\mathbf{2 0 0 6}$ \\
\hline Desenvolvimento de softwares sob encomenda & 33,4 & 30,8 & 30,4 & 31,4 \\
\hline $\begin{array}{l}\text { Desenvolvimento, edição e licenciamento de softwares } \\
\text { prontos para uso }\end{array}$ & 19,0 & 18,1 & 17,1 & 16,7 \\
\hline Tratamento de dados e hospedagem de sites & 15,0 & 15,2 & 16,7 & 14,7 \\
\hline Consultoria em TI & 10,4 & 14,5 & 14,7 & 15,0 \\
\hline Manutenção & 7,7 & 7,8 & 7,3 & 4,9 \\
\hline Outros serviços & 14,4 & 13,7 & 13,8 & 17,3 \\
\hline
\end{tabular}

Fonte: adaptado de IBGE, 2006.

No entanto, os serviços de manutenção também apresentaram perda de participação, passando de um patamar médio de 7,5\%, no período de 2003 a 2005, para 4,9\%, em 2006. A Tabela 4.4 mostra no conjunto de produtos e serviços relacionados ao desenvolvimento de softwares sob encomenda, destaca-se o desenvolvimento de softwares específicos para o cliente, que envolve projeto, programação ou desenvolvimento, testes, implantação, preparo de documentação, etc. Na tabela 4.4, observa-se que esses produtos responderam, em 2006, por 68,6\% das receitas. Por outro lado, os serviços de outsourcing apresentaram perdas de participação, passando de 33,9\%, em 2003, para 26,0\%, em 2006, enquanto os serviços de projetos para banco de dados e criação de sites representam parcelas pouco expressivas. 
Tabela 4.4 Participação de desenvolvimento de softwares sob encomenda e outsourcing no total da receita de serviços de informática - Brasil - 2003-2006 (\%)

\begin{tabular}{l|c|c|c|c}
\hline \multicolumn{1}{c|}{ Serviço } & $\mathbf{2 0 0 3}$ & $\mathbf{2 0 0 4}$ & $\mathbf{2 0 0 5}$ & $\mathbf{2 0 0 6}$ \\
\hline Desenvolvimento de softwares sob encomenda & 59,8 & 59,7 & 67,5 & 68,6 \\
\hline Outsourcing & 33,9 & 30,6 & 27,9 & 26,0 \\
\hline Projeto para banco de dados & 4,3 & 6,0 & 2,1 & 3,3 \\
\hline Criação de sites & 1,9 & 3,7 & 2,5 & 2,1 \\
\hline
\end{tabular}

Fonte: adaptado de IBGE, 2006.

A necessidade de assegurar crescimento econômico aliado ao desenvolvimento tecnológico resultou em investimentos de C\&T por parte do Estado, de acordo com dados do MCT, em média nos anos de 2000 a 2007, 0,47\% do PIB (Governo Federal) e 0,21\% do PIB (Governo Estadual). Destaca-se, porém, que nesse mesmo período foi o setor empresarial (iniciativa privada) que mais investiu em ciência e tecnologia, em média $0,69 \%$ do PIB.

A análise dos dados demonstra que houve significativo avanço do setor de TI neste período, refletindo uma tendência de diversificação das atividades produtivas. A própria ênfase nas políticas de ciência e tecnologia expressam a importância dos investimentos financeiros para a consolidação de parques tecnológicos.

Álvares (2013, p.71) afirma que, no Brasil, os primeiros parques tecnológicos têm mais de vinte anos de existência tendo a ANPROTEC (Associação Nacional de Entidades Promotoras de Empreendimentos Inovadores) como principal instituição desde 1987. Nesse período, o apoio mútuo e conjunto do Ministério da Ciência e Tecnologia (MCT), da Financiadora de Estudos e Projetos (FINEP), do Conselho Nacional de Desenvolvimento Científico e Tecnológico (CNPq), do Serviço Brasileiro de Apoio às Micro e Pequenas Empresas (SEBRAE) e da ANPROTEC proporcionaram um forte impulso a esses ambientes de inovação no país.

O surgimento dos parques tecnológicos no Brasil não foi semelhante aos países como França e Japão que utilizaram essa modalidade como um instrumento de desenvolvimento econômico e regional. De acordo com Tavares (1993, p.277), embora as metrópoles brasileiras sejam também geradoras de produção de alta tecnologia, os parques tecnológicos no país estão distantes das experiências internacionais. Mas os esforços deliberados de interação entre universidades, empresas e governo, voltados para a produção de inovações conseguiu lugar na esfera produtiva, principalmente na Região Sudeste. 
O Quadro 4.2 mostra os principais parques tecnológicos brasileiros distribuídos principalmente nas Regiões Sul e Sudeste do país. Este cenário revela que a implementação de parques tecnológicos no Brasil acompanhou o processo de concentração industrial do país. As áreas que antes concentravam um processo acelerado de industrialização, agora concentram esforços para estabelecer empresas de inovação.

\section{Quadro 4.2 Parques tecnológicos no Brasil}

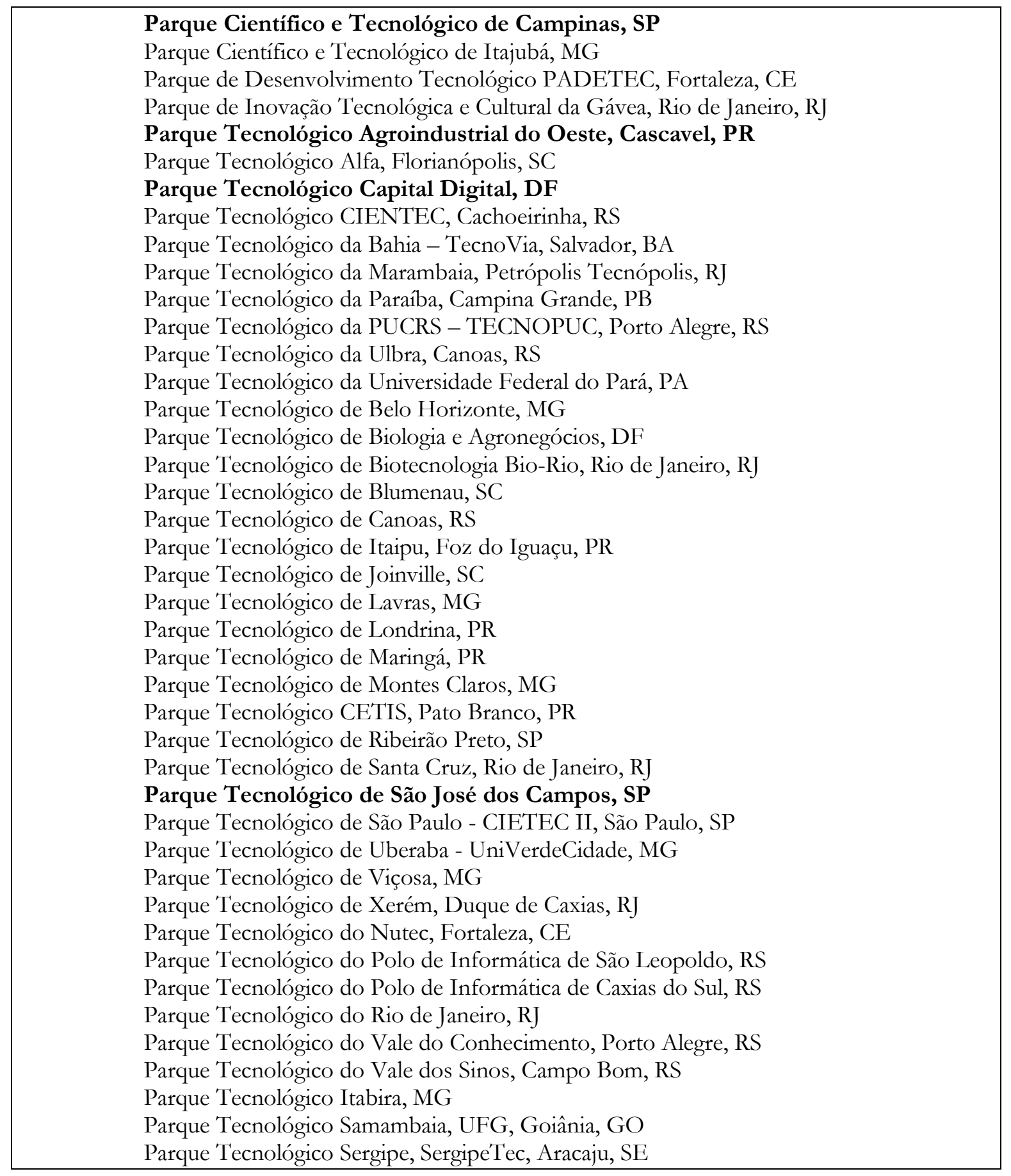




\begin{tabular}{|l|}
\hline Parque Tecnológico Titan, Eusébio, CE \\
Parque Tecnológico UNIVAP, São José dos Campos, SP \\
Porto Digital, Recife, PE \\
São Carlos Science Park, São Carlos, SP \\
Sapiens Parque, Florianópolis, SC \\
Polo Industrial de Manaus PIM, AM
\end{tabular}

Fonte: elaborado pelo autor.

Destacaram-se nesse sentido, as experiências de São Paulo, principalmente de Campinas, São José dos Campos e São Carlos. Na região Sul, a experiência do Estado do Paraná nas cidades de Curitiba e Cascavel, do Estado de Santa Catarina, a cidade de Florianópolis e no Estado do Rio Grande do Sul, a cidade de Porto Alegre. Estas experiências foram realizadas para enfrentar os desafios trazidos pela sociedade do conhecimento e para incorporar os novos procedimentos relacionados à competitividade das empresas e à acumulação flexível. Verifiquem-se as principais características dessas experiências.

O processo de industrialização de São Paulo acompanhou o processo de desenvolvimento histórico e de formação da indústria brasileira. Teve como características principais: estrutura industrial completa, marcada por diversificação dos setores da indústria de transformação; parque industrial bastante diversificado, notadamente na capital paulista; movimento de desconcentração industrial direcionado para o interior do Estado e para outras regiões, motivado pela busca de custos salariais mais reduzidos e o aproveitamento dos diversos incentivos fiscais e creditícios oferecidos na região Nordeste; várias instituições voltadas para a formação e difusão de inovações tecnológicas.

De acordo com SOUZA; GARCIA (1999, p. 311), no Estado de São Paulo, podem ser identificadas regiões com aglomerações setoriais, ou seja, especializadas e reconhecidas como um dos elementos importantes para a formação de sistemas regionais ou locais de inovações. Os autores as distinguem em três categorias: 1) parques tecnológicos, que compreendem arranjos locais com presença de produtores especializados em setores de alta tecnologia; 2) distritos industriais, formados pela aglomeração de pequenas e médias empresas, geralmente em setores tradicionais, como têxtil e vestuário, calçados, móveis; 3) redes de subcontratação, caracterizadas pela presença de uma grande empresa coordenadora das ações de vários fornecedores de peças e componentes. Os parques tecnológicos paulistas apresentam características semelhantes àqueles norteamericanos e são identificados em três regiões: Campinas, São José dos Campos e, São Carlos. 
O parque tecnológico de Campinas é caracterizado por um conjunto de empresas, atuando em setores de alta tecnologia, cuja proximidade a universidades e centros de pesquisas tecnológicas representa sinergias para os produtores locais. Essas empresas de alta tecnologia atuam principalmente nos ramos de informática, microeletrônica, telecomunicações, opto-eletrônica e química fina. O destaque é para a acentuada presença de empresas de pequeno e médio porte no ramo da informática, voltadas para a produção de software (SOUZA; GARCIA, 1999, p. 313).

Mendes (2014, p.5) considera o parque tecnológico de Campinas uma região inteligente, com espaços totalmente integrados, logisticamente ideais, com alta tecnologia e sustentáveis. O parque possui infraestrutura condominial com serviços de segurança, restaurante, portaria, manutenção e telecomunicações). A instituição responsável pelo desenvolvimento do parque tecnológico de Campinas é o Centro de Indústrias de Alta Tecnologia - CIATEC, composta por três instâncias: assembleia geral de caráter deliberativo, diretoria de caráter executivo e o conselho fiscal, órgão de controle (GOMES, 1993, p. 57). A sua localização privilegiada contribui para o seu papel tecnológico relevante. O parque está localizado na cidade de Campinas entre as três mais importantes rodovias paulistas (Dom Pedro, Anhanguera e Bandeirantes), próximo ao maior aeroporto de cargas do país, o aeroporto de Viracopos e a $150 \mathrm{~km}$ do porto de Santos. Dentre as empresas presentes no parque estão: Intel, At\&t, Ascenty, Capgemini, Cellcom, HUAWEI, CanaVialis e Oxitec. A Figura 4.2 mostra a vista aérea do Techno Park Campinas em que as empresas estão instaladas próximas ao lado de um parque com vegetação remanescente da Mata Atlântica. Ao fundo parte superior direita da imagem a cidade de Campinas, uma das dez cidades com maior PIB do país com mais de 20.000 empresas de serviços, de acordo com IBGE (2015). 


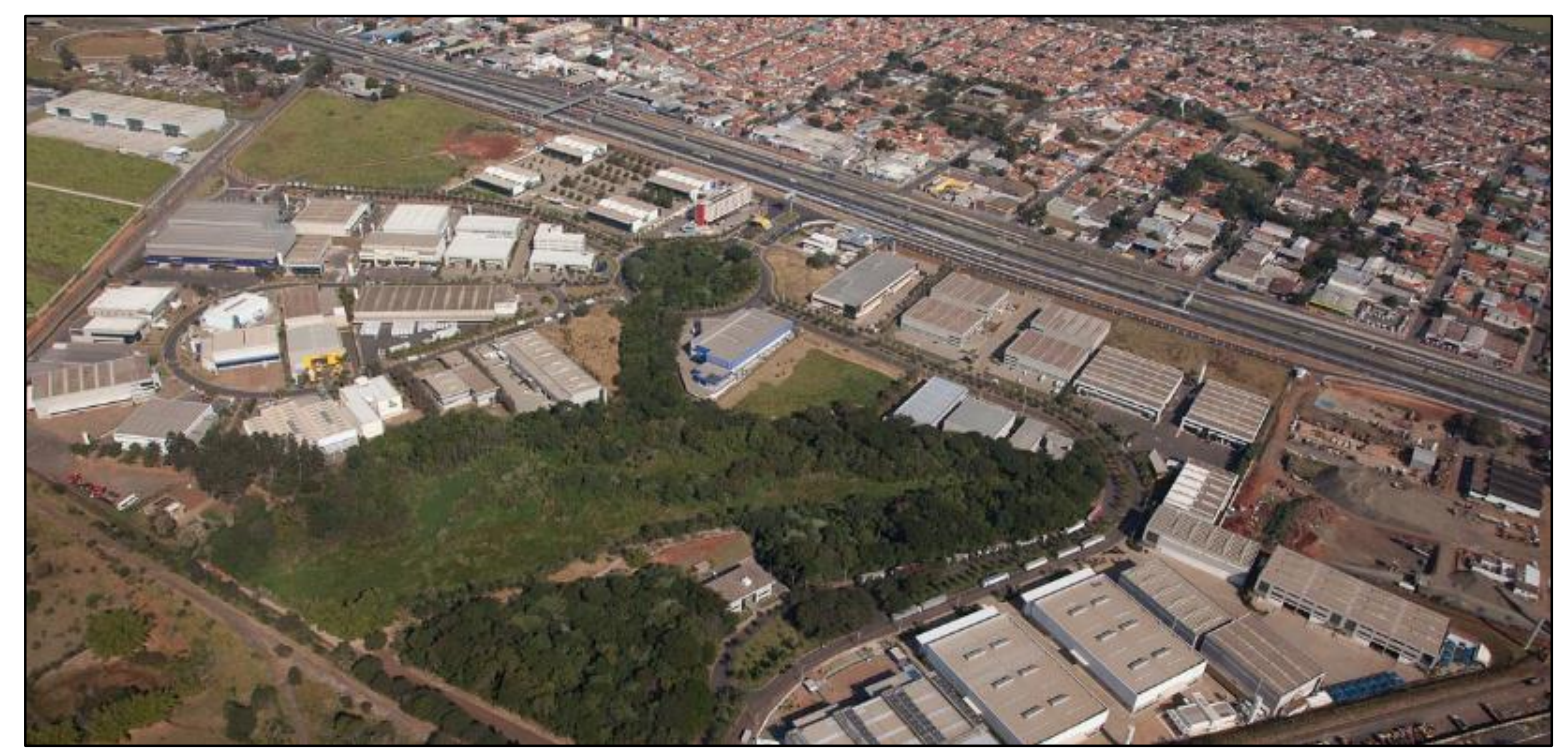

Figura 4.2 Techno Park Campinas

Mostra a vista aérea do Techno Park Campinas em que as empresas estão instaladas próximas ao lado de um parque com vegetação remanescente da Mata Atlantica.

Fonte: ANPROTEC (2013).

O parque tecnológico de São José dos Campos é caracterizado pela presença de considerável infraestrutura de órgãos e instituições voltadas para a produção de C\&T. As empresas presentes são dos setores bélico e espacial. O destaque é para existência de laços cooperativos entre os institutos de pesquisa locais e as empresas dos setores bélico e aeroespacial, que têm produzido importantes efeitos no processo de geração de inovações tecnológicas (SOUZA; GARCIA, 1999, p. 315). Dentre estes efeitos Whitacker (2007) analisa o surgimento de áreas de empregos de alta tecnologia nas principais vias de ligação de São José dos Campos, ao passo que a centralidade tradicional tende a permanecer em seu local historicamente construído, no centro "tradicional" da cidade.

O parque tecnológico de São José dos Campos é gerenciado por uma fundação de direito privado, sem fins lucrativos, com autonomia administrativa e financeira - a Fundação Polo Tecnológico de São José dos Campos e Vale do Paraíba - Polo Vale que possui estrutura organizacional composta por três instâncias: conselho curador, com poderes de máxima deliberação; diretoria encarregada da administração; conselho fiscal, órgão de controle e ainda dois comitês assessores, representados pelo conselho comunitário e por um grupo de consultores. As instituições presentes são: Associação Comercial e Industrial de São José dos Campos - ACISJC, Secretaria de Estado de Ciência, Tecnologia e Desenvolvimento Econômico - SCTDE, Centro das Indústrias do Estado de São Paulo - 
CIESP, Prefeitura Municipal de São José dos Campos - PMSJC, SEBRAE/SP, Instituto Nacional de Pesquisas Espaciais - INPE, Centro Técnico da Aeronáutica - CTA e Universidade do Vale do Paraíba - UNIVAP (GOMES, 1993, p.38-9).

O parque tecnológico de São Carlos apresenta semelhanças ao Silicon Valley norte-americano, pois sua criação está vinculada à iniciativa de alguns professores universitários de criar empresas de base tecnológica, aproveitando-se do conhecimento acumulado na academia. A empresa inicial possuía atividades na área de laser (SOUZA; GARCIA, 1999, p. 315).

O São Carlos Science Park foi construído na área de um antigo horto florestal, possuindo uma arquitetura colonial, inspirado nos casarões de das fazendas de café. Possui um edifício sede denominado Solar da Inovação onde se encontram as instalações das empresa e um restaurante. A Figura 4.3 mostra o edifício sede do São Carlos Science Park que possui um estilo colonial elaborado com base nas antigas fazendas de café da região.

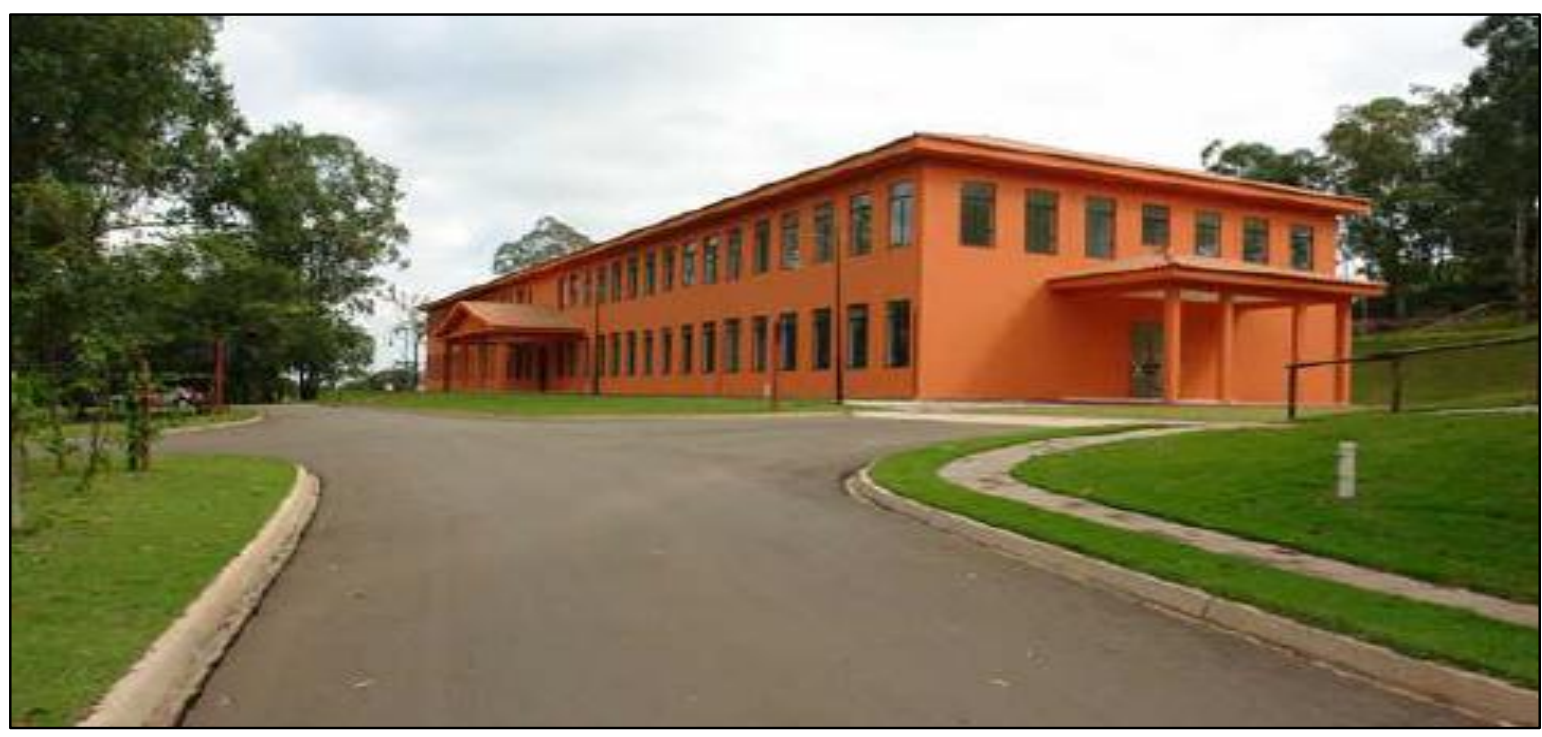

Figura 4.3 Solar da Inovação do São Carlos Science Park

O edificio sede do São Carlos Science Park possui estilo colonial elaborado com base nas antigas fazendas de café da região. O prédio em estilo de sobrado possui dois andares (a partir do térreo) divididos em 33 salas empresariais.

Fonte: ANPROTEC (2013)

A Figura 4.4 mostra a fachada da entrada principal do edifício sede o Solar da Inovação do São Carlos Science Park. A fachada recebeu acabamentos e detalhes de objetos no estilo colonial para lembrar as antigas fazendas cafeeiras da região. No parque funcionam empresas da área de tecnologia da informação e comunicação. 


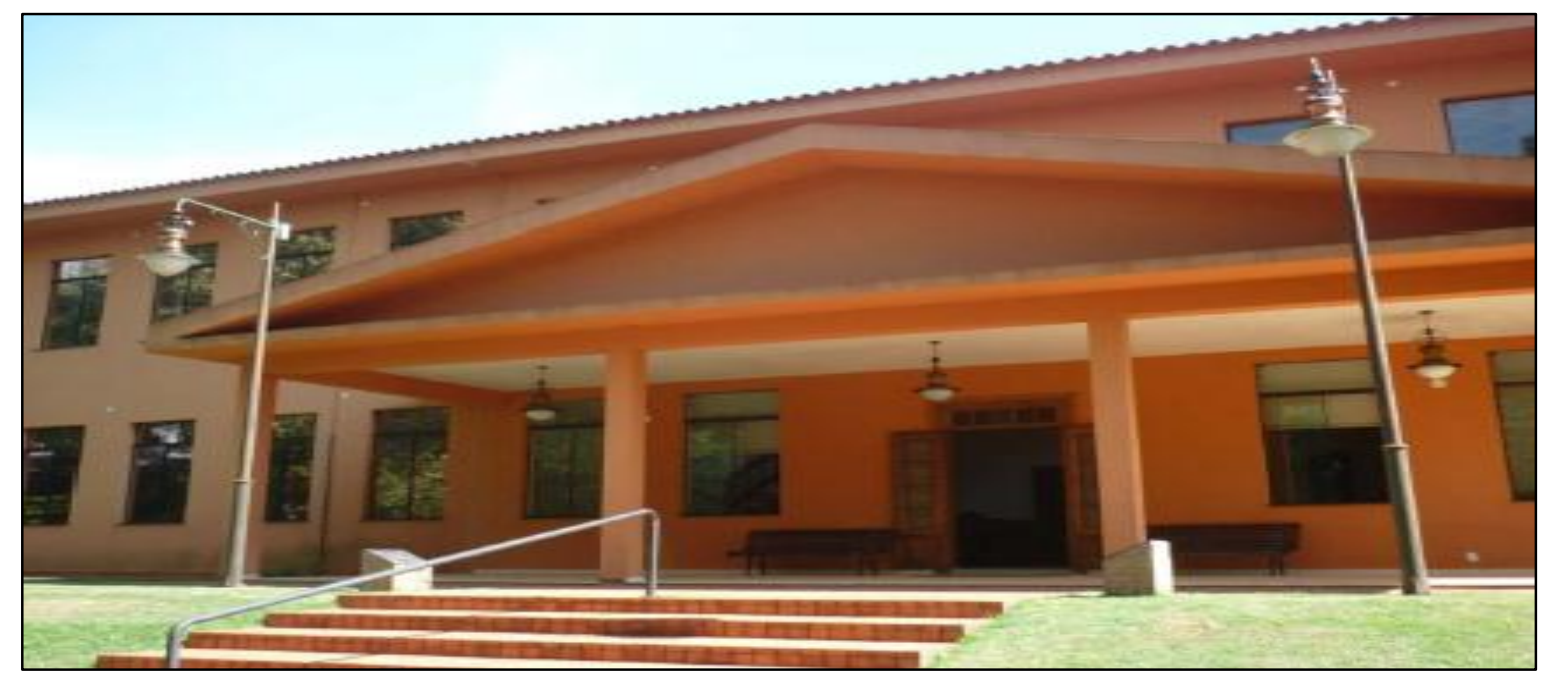

Figura 4.4 Entrada do edifício sede do parque tecnológico São Carlos Science Park

Mostra a fachada da entrada principal do edifício sede o Solar da Inovaşão do São Carlos Science Park. A fachada recebeu acabamentos e detalhes de objetos no estilo colonial.

Fonte: ANPROTEC (2013).

O parque tecnológico de São Carlos tem como estrutura organizacional a Fundação Parque de Alta Tecnologia de São Carlos - PaqTc-SCar composta de três instâncias: conselho de curadores, órgão de máxima deliberação; diretoria, encarregada da administração e o conselho técnico-científico, órgão de caráter consultivo. As principais instituições participantes são: Centro de Desenvolvimento de Indústrias Nascentes de São Carlos - CEDIN, SCTDE e universidades (GOMES, 1993, p. 48-52).

O crescimento tecnológico paranaense começou nos anos 1980 quando o Governo estadual efetivou categorias funcionais e orçamentárias para dispêndio em ciência e tecnologia. O sistema local de inovações paranaense é relativamente modesto, se comparado com o desenvolvimento verificado na região Sudeste.

No sistema de inovação local do Estado destacam-se dois parques tecnológicos: Cascavel e Curitiba. O primeiro apresenta um conjunto de infraestruturas, serviços e facilidades tecnológicas, como laboratórios, centros de treinamento, visando atrair empresas nas suas áreas industriais disponíveis e gerar novas empresas a partir de sua própria incubadora, bem como prestar serviços e promover a difusão tecnológica para as empresas já localizadas na região. O segundo apresenta infraestrutura específica para a área de software, como telecomunicações, laboratórios, área de treinamento, provedores, sendo o mesmo gerenciado por uma entidade civil sem fins lucrativos (PASSOS, 1999, p.348-9). 
O desenvolvimento científico-tecnológico do Estado de Santa Catarina teve início com a dinâmica de arranjos institucionais locais que configuraram experiências inovativas. Esses arranjos envolvem instituições públicas e privadas, em relações formais e informais, voltados a desenvolver processos de aprendizagem tecnológica como instrumentos de sustentação ou criação de vantagens competitivas. A materialização desses arranjos exprime-se através da estruturação do parque tecnológico em Florianópolis como uma experiência que caracteriza um arranjo típico de atividades cooperativas voltadas para o desenvolvimento tecnológico, envolvidas pela presença de órgãos de pesquisa de ciência e tecnologia (CAMPOS et al, 1999, p.387).

O desenvolvimento tecnológico em Florianópolis, não ocorreu de forma isolada. Houve uma política governamental, em nível estadual e municipal, de incentivo às empresas pioneiras, treinamento de mão de obra qualificada, criação de áreas para desenvolvimento de parques tecnológicos, incentivo à pesquisa e investimentos em obras infraestruturais atraentes ao capital. Com isso, o setor cresceu rapidamente gerando volumosos avanços tecnológicos (VIEIRA, 1996, p.101).

O parque tecnológico de Florianópolis apresenta uma dinâmica de arranjo centrado no desenvolvimento científico-tecnológico, apoiado em recursos do Estado e na relação universidade e empresa. Reúne as seguintes características: externalidades positivas proporcionadas ao entorno geográfico, na região da Grande Florianópolis e também no interior do Estado, e a aprendizagem institucional (CAMPOS et al, 1999, p.392).

O órgão responsável pelo parque tecnológico é o Conselho do Polo Tecnológico da Grande Florianópolis - CONTEC, composto por 25 entidades públicas e privadas reunidas pela Secretaria de Tecnologia, Energia e Meio Ambiente - STEMA. O CONTEC é um órgão de deliberação coletiva que visa o estabelecimento da política, das estratégias, diretrizes e metas do parque tecnológico, sendo organizados em quatro níveis: plenário, presidência, duas vice-presidências e secretário executivo (GOMES, 1993, p.84).

Até este ponto enfatizamos exemplos voltados quase que exclusivamente para o desenvolvimento econômico. Agora vamos apresentar uma experiência com parques tecnológicos brasileiros que se distingue por apresentar uma preocupação ambiental. Este é o Polo Industrial de Manaus (PIM) e o seu Zoneamento Ecológico Econômico (ZEE).

O Polo Industrial de Manaus (PIM) localizado no Estado do Amazonas é um modelo industrial tradicional, mas que possui atividades típicas de um parque tecnológico 
e também a sua importância socioeconômica ${ }^{56}$ no território usado. As atividades desenvolvidas no polo são nas áreas de eletroeletrônico, duas rodas, químico, metalúrgico, termoplástico, descartáveis, relojoeiro, papel e papelão, ótico, editorial e gráfico e mobiliário (SUFRAMA, 2016).

O PIM integra a Zona Franca de Manaus (ZFM) sob a coordenação da Superintendência da Zona Franca de Manaus - SUFRAMA ${ }^{57}$. Este órgão tem a função de desenvolver os três polos da ZFM, o comercial, o industrial e o agropecuário. Além do PIM, a ZFM conta com o Distrito Agropecuário e um polo naval. A ZFM oferece incentivos fiscais na tentativa de atrair a instalação de novas empresas e investimentos em sua área. A ZFM oferece ainda, incentivos extrafiscais disponibilizando às empresas sob a forma de incentivo locacional, lotes fundiários para a utilização industrial ao preço simbólico aproximado de US\$ 0,30 por metro quadrado ${ }^{58}$ (SUFRAMA, 2016).

O Centro de Ciência, Tecnologia e Inovação - CT do polo industrial, criado em 2003, é um centro de pesquisa, desenvolvimento e inovação voltado para o PIM. Os seus objetivos são o domínio das tecnologias avançadas, a viabilização de práticas e conhecimentos com foco na inovação e a elevação da competitividade. A Figura 4.5 mostra o edifício sede do CT-PIM que tem parcerias com centros internacionais ${ }^{59}$ nas áreas de microtecnologia eletrônica, confiabilidade de sistemas e microbiotecnologia (SUFRAMA, 2016).

Existe ainda no polo, o Centro de Biotecnologia da Amazônia - CBA, responsável por projetos de atividades econômicas com base em inovações nas áreas de análises físico-químicas, microbiológicas, serviços técnicos especializados como ensaios de eficácia e segurança tecnológica (SUFRAMA, 2016). A Figura 4.6 mostra o edifício sede do CBA com as suas instalações modernas.

Para tentar diminuir a vulnerabilidade ambiental no território usado, elaborouse o Zoneamento Ecológico Econômico (ZEE) do Polo Industrial de Manaus (PIM). Na tentativa de manter o papel industrial do polo como fornecedor de itens essenciais, a sua

\footnotetext{
${ }^{56}$ De acordo com a SUFRAMA, em 2014, o PIM alcançou o faturamento de US $\$ 37,1$ bilhões.

57 A SUFRAMA é uma autarquia federal vinculada ao Ministério do Desenvolvimento, Indústria e Comércio Exterior - MDIC.

${ }^{58}$ Esta vantagem de incentivo locacional poderia ser pensada para o PTCD, tendo em vista que um dos maiores entraves a sua consolidação é justamente o valor especulativo imobiliário de seus lotes.

${ }^{59}$ Por exemplo com o Leti Minetec, na França, na área de microbiotecnologia e sistemas mecânicosmicroeletrônicos.
} 
importância socioeconômica para a cidade de Manaus, a fragilidade do ecossistema em que está inserido, sua capacidade de suporte, elaborou-se o ZEE.
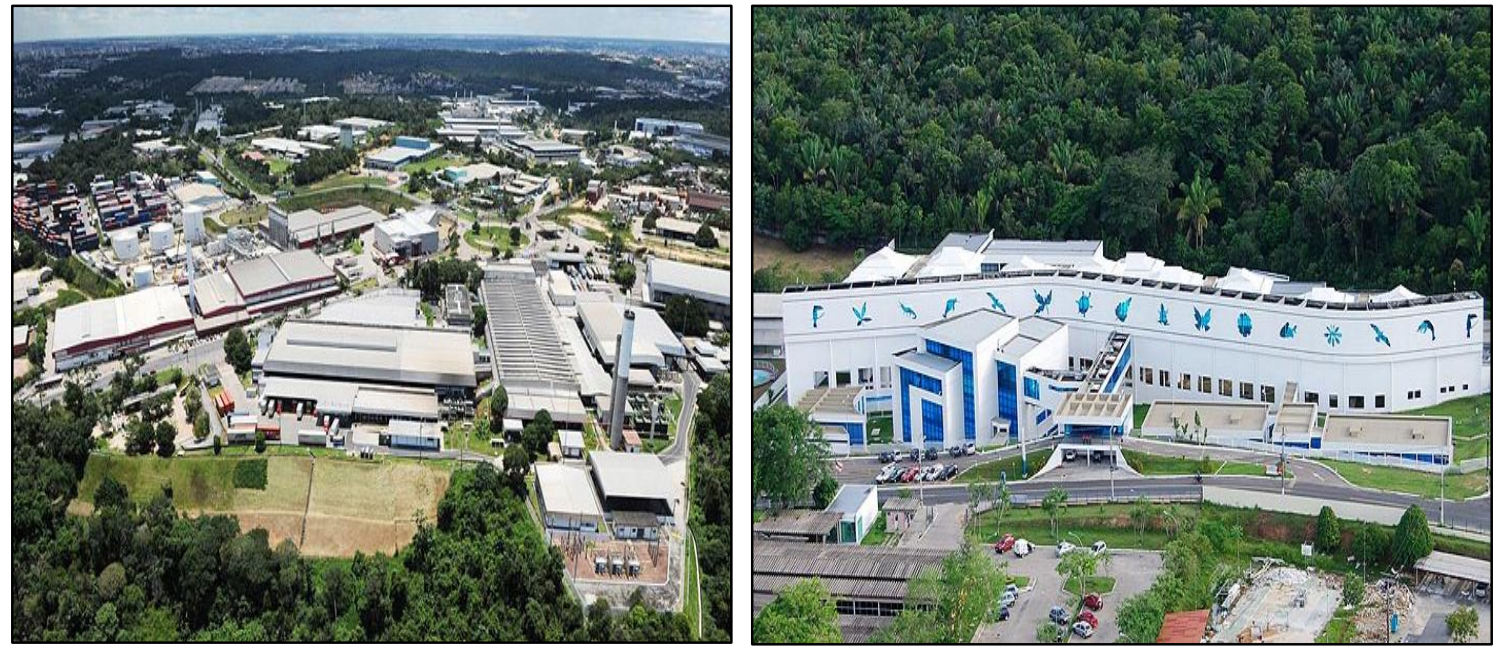

Figuras 4.5 e 4.6 Imagens aéreas do PIM

Figuras 4.5 e 4.6: mostra vista aérea do PIM; vista aérea do CBA, com uma área construida de 12 mil metros quadrados. O CBA está dividido em mais de trinta unidades componentes, dentre as quais laboratórios, unidades de apoio tecnológico, unidades de apoio técnico e áreas administrativas. Fonte: SUFRAMA, 2016.

O zoneamento ecológico econômico (ZEE) é um dos instrumentos da Política Nacional do Meio Ambiente e tem por objetivo regular o uso e a ocupação do solo, estabelecendo a divisão do território em parcelas, nas quais poderá ser autorizada ou vetada, total ou parcialmente, a realização de determinadas atividades. O zoneamento ambiental é referenciado no inciso II, artigo $9^{\circ}$ da Lei n. $^{\circ} 6.938 / 81$ e tem como principal função o planejamento do uso do solo baseado nas características de cada localidade, de forma a mapear o potencial de cada região, definindo os usos possíveis sem comprometer seus recursos naturais e o meio ambiente.

O ZEE é um meio de restringir o uso do solo, uma vez que define quais atividades podem ou não ser executadas em cada região delimitada. Essa restrição visa garantir o uso adequado e sustentável em longo prazo, obedecendo a uma análise minuciosa e integrada de todas as variáveis envolvidas na questão da influência antrópica na região versus a capacidade de suporte. Está previsto também no artigo $2^{\circ}$, II e III e, artigo $4^{\circ}$, III, alínea "c" e, inc. V, da Lei 10.257/01. O zoneamento ambiental surge como instrumento de planejamento que objetiva reduzir conflitos e impedir que a atividade produtiva possa causar danos ao meio ambiente ou prejuízos a terceiros, procurando localizar as fontes poluidoras da atividade em locais menos incomodativos ou em que possam ser evitados completamente seus efeitos. 
O objetivo do ZEE do PIM é antes de tudo a identificação das atividades produtivas que aumentam a vulnerabilidade ambiental no território usado. Assim, os usos do território estão sendo coordenados para a redução do dano ambiental com a utilização de alternativas sustentáveis. O ZEE do PIM está sendo realizado numa proposta de Simbiose Industrial (SI) ${ }^{60}$, uma ferramenta de Ecologia Industrial ${ }^{61}$ em que as indústrias estariam em cooperação mútua, trocando informações, energia e subprodutos, sem gerar descartes no meio natural, evitando o acúmulo destes dejetos e evitando o dano ambiental.

Esta abordagem do ZEE prevê uma necessidade de cooperação entre as empresas dos mais variados segmentos na mesma localidade para o alcance de resultados melhores do que aqueles que seriam obtidos individualmente. De acordo com Rivas et al (2008, p.42) o ZEE tem reduzido o impacto ambiental do PIM, mas consideram que em função das atividades desenvolvidas pelo polo (eletroeletrônico e duas rodas) não ocorrem danos ambientais de grandes proporções.

Podemos citar como exemplo de aplicação da SI no PIM, a reciclagem de resíduos de papéis e seus derivados ${ }^{62}$. Quase todas as empresas do PIM geram resíduos de papéis. Estes resíduos de papéis entram no processo de reciclagem sendo enviados por meio de empresas coletoras e organizadoras à empresa de papel e papelão do polo, reduzindo os danos ambientais. O processo de reciclagem também pode ser entendido com responsabilidade socioambiental das empresas que geram empregos e reduzem os danos ambientais.

O Zoneamento Ecológico Econômico do Polo Industrial de Manaus pode ser pensado para outras iniciativas de parques tecnológicos que se encontrem localizadas em áreas com grande vulnerabilidade ambiental e que possuam processo produtivo de "baixo" impacto ambiental. As experiências com parques tecnológicos no Brasil possuem algumas características comuns entre elas: a presença prévia de um processo de industrialização e de empresas de pequeno e médio porte; especializações regionais/ locais; presença de instituições públicas de ciência e tecnologia; participação de empresas privadas no processo de inovação tecnológica.

\footnotetext{
${ }^{60}$ Conceito apropriado da biologia, uma associação entre dois ou mais organismos. Nessa perspectiva, as indústrias estariam em cooperação/interação estabelecendo relações interorganizacionais (CHERTON, 2007).

${ }^{61}$ Preceitua o conceito o equilíbrio entre o atendimento das necessidades humanas e a manutenção do meio ambiente (CAPRA, 2005).

${ }^{62}$ Resíduos de papéis são descartes comuns e em grandes quantidades em parques tecnológicos.
} 


\section{Capítulo 5}

\section{ACUMULAÇÃO FLEXÍVEL E REORGANIZAÇÃO PRODUTIVA EM BRASÍLIA}

\footnotetext{
Nascida como mito da realidade, Brasília, a capital administrativa planejada tornou-se o palco das contradições inerentes ao processo de acumulação. $\mathrm{O}$ imaginário do arquiteto Lúcio Costa não foi suficiente para desprender a capital do modelo singular das estruturas dominantes presentes nas grandes cidades, mas conseguiu que a cidade correspondesse à própria imagem que o Estado faz necessariamente de si .

(BICCA, Paulo. Brasília: mitos e realidades. In: PAVIANI. A.; BICCA, P. (orgs.). Brasília, ideologia e realidade: espaço urbano em questão. São Paulo: Projeto, 1985, p.115)
} 


\subsection{Consolidação do território usado de Brasília até o final dos anos 1960}

Discorrer sobre os usos do território metropolitano brasiliense é desafiador. Brasília sempre esteve em nosso imaginário moldada e perfeita, resultado de um urbanismo racionalista. No entanto, essa cidade ideal não é a nossa cidade real, do nosso espaço vivido, das nossas intencionalidades. Assim, se impõem as práticas de poder sobre o nosso território usado, sendo necessária a sua gestão. Segundo Becker (1991, p.178) a gestão do território corresponde à prática das relações de poder necessária para dirigir no espaço-tempo, a coerência das múltiplas finalidades, decisões e ações no território usado. Cidade (1997, p.42) considera ainda, a gestão do território a prática estratégica, científicotecnológica do poder no espaço-tempo. Por sua vez, Corrêa (1997) considera a gestão do território como fruto das relações imemoriais, responsáveis pelo sentimento de identidade e pela reprodução de grupos sociais específicos ao longo da história.

O principal agente de gestão do território é o Estado por possuir posição estratégica e privilegiada em relação aos demais agentes. O Estado por meio dos mecanismos de gestão deseja racionalizar a vida econômica e política que vem ao encontro da reestruturação mundial da acumulação flexível em bases científicas e tecnológicas. As suas ações sobre o território usado representam sua afirmação enquanto agente de transformação espacial e passam a requerer novas formas de planejamento para a reorganização produtiva do território metropolitano.

A formação socioeconômica de Brasília implicou a presença de uma superestrutura constituída pelas instituições políticas e organizacionais em que o Estado foi o principal elemento dessa estrutura no processo de gestão do território usado. A análise da evolução urbana de Brasília demonstra o papel importante que o Estado por meio de seus instrumentos de planejamento interferiu no território usado configurando novas estruturas capazes de refletirem a dinâmica socioeconômica da cidade.

Brasília surgiu por motivos estratégicos relacionados aos interesses dos grandes estadistas, sendo a sua construção prevista institucionalmente no dispositivo constitucional de 1891, que determinava a interiorização da Capital. Permanecia o desejo de desenvolver o interior do país e também assegurar estrategicamente a localização do governo pois o cenário político seria deslocado de certa forma do então centralizado no sudeste (CRULS, 1992; BELCHER, 1995). 
Para a concretização realizou-se o Relatório da Comissão Exploradora do Planalto Central do Brasil (Relatório Cruls) com o intuito de demarcar a área em que a futura capital do Brasil seria inserida e estabelecida, bem como levantar os dados sobre as características ambientais da área. O relatório Cruls foi o primeiro levantamento e mapeamento do sítio da capital possuindo grande importância histórica, pois apresenta a memória histórica e cartográfica do Distrito Federal.

Em 1954, a empresa Donald J. Belcher and Associates Incorporated de Ithaca, New York, U.S.A realizou o levantamento para a seleção inicial de cinco áreas consideradas próprias à implantação da nova capital. O Relatório Belcher em suas diretrizes afirmava que a escolha de um sítio para a construção de uma cidade requer grande responsabilidade e cautela tendo em vista que erros ou imperfeições podem afetar para sempre os aspectos socioeconômicos da mesma (BELCHER, 1995, p.27).

De acordo com Belcher (1995, p.27) os fatores que determinam o desenvolvimento ou crescimento de uma cidade são geográficos: uma posição privilegiada em via de transporte aquática ou terrestre, uma posição militarmente estratégica ou uma posição dominante do ponto de vista político. No caso da nova Capital deveria esta preencher um outro papel que a diferenciaria das demais cidades, um centro governamental, portanto, não sendo diretamente influenciada pelo comércio interior e exterior ou pela indústria.

As razões que levaram à transferência da capital foram antes de mais nada político-estratégicas. De um lado era um sonho dos grandes estadistas, por outro estava prevista institucionalmente no dispositivo constitucional de 1891, que determinava a interiorização da capital. Havia ainda, o desejo de desenvolver o interior do país e também assegurar estrategicamente a localização do governo.

Em 1957, foi lançado o edital do Concurso do Plano Piloto de Brasília. O plano aprovado foi a proposta de Lúcio Costa, que pretendia atribuir a cidade o desejado caráter monumental. Da sua proposta destaca-se: "Nasceu do gesto primário de quem assinala um lugar ou dele toma posse: dois eixos cruzando-se em ângulo reto, ou seja, o próprio sinal da cruz".

Brasília, ao longo de seu desenvolvimento, apresentou sérias dificuldades para abrigar convenientemente seus habitantes por causa de seu intenso crescimento que resultou, também, da coincidência do começo de sua implantação ter ocorrido com o início do intenso movimento migratório interno, do campo e das pequenas e médias cidades em direção às grandes cidades, iniciado na década de 1950. 
Nem mesmo as ações governamentais contidas nos planos federal e nacional, como a criação da Comissão Nacional da Habitação em 1961, cujas características eram a coordenação centralizada da aplicação dos recursos destinados à habitação, foram capazes de conter a migração descontrolada para Brasília a partir de 1960.

\subsection{A emergência do setor de serviços em Brasília até o início dos anos 1990}

Nos anos de 1970, a dependência econômica do Distrito Federal dos setores de administração pública e construção civil indicou a não existência de um setor de atividades econômicas, capaz de absorver, a longo prazo, o crescente contingente de mão de obra não

qualificada. A dinâmica produtiva mostrou ainda que existiam ainda mais empregos no Plano Piloto do que empregados morando no Plano Piloto.

Dados do PEOT (1977) apontavam uma maior concentração de renda bruta estava no Plano Piloto, $61 \%$ do total, representando em termos de população apenas $27 \%$. Para os $73 \%$ da população restante sobram apenas $39 \%$ de renda. Com isso os equipamentos sociais se concentravam no Plano Piloto por apresentar os melhores índices de poder aquisitivo. Nas áreas de renda elevadas as taxas de escolarização registradas ultrapassavam a casa dos $96 \%$ em detrimento das outras que obtiveram índices abaixo da média entre 86 - 90\%.

O mercado de trabalho de uma cidade está relacionado às funções econômicas que a cidade preenche e a capacidade de absorção de força de trabalho expressa o dinamismo dessas funções. Brasília por possuir a função básica de administração pública, acabou não desenvolvendo prioritariamente outras atividades, porém o avanço e o crescimento da cidade gerou uma nova dinâmica no setor de empregos.

Essa dinâmica consistiu na alteração da distribuição das atividades, como demonstra a Tabela 5.1 na comparação entre os dados do Censo de 1970 e as estimativas da Companhia de Planejamento do Distrito Federal - CODEPLAN de 1983. 
Tabela 5.1 Pessoas ocupadas no Distrito Federal (1970 e 1983)

Pessoas Ocupadas em \% do emprego total (Censo de 1970)

\begin{tabular}{l|l}
\hline Serviços & $62 \%$ \\
\hline Construção civil & $19 \%$ \\
\hline Comércio de mercadorias & $9,4 \%$ \\
\hline Outros & $9,6 \%$ \\
\hline
\end{tabular}

Pessoas Ocupadas em \% do emprego total (Estimativas CODEPLAN - 1983)

\begin{tabular}{l|l}
\hline Serviços & $85 \%$ \\
\hline Construção civil & $5 \%$ \\
\hline Comércio de mercadorias & $3,6 \%$ \\
\hline Outros & $6,4 \%$ \\
\hline
\end{tabular}

Fonte: Adaptado dos Anexos PEOT (1977) e Estimativas CODEPLAN (1983).

A comparação entre os dados da Tabela 5.1 mostram que houve um decréscimo no número de pessoas ocupadas na construção civil, pois as grandes construções no início da década de 1980 diminuíram ocasionando a formação de grande excedente de mão de obra. A capacidade de absorção de mão de obra do Distrito Federal neste período foi decrescendo ao longo da década de 1980.

No início dos anos 1980, o problema se agravou em consequência da desestabilização da economia nacional fato este que comprometeu diretamente o mercado de trabalho na cidade. Neste período o setor terciário no Distrito Federal ainda representava o principal meio empregatício, porém devido as dificuldades financeiras, ao baixo desenvolvimento da economia do país e o alto fluxo migratório para Brasília este setor começou a ficar saturado e não foi capaz de absorver a mão de obra excedente (PDOT,1996, p.45).

A participação do setor industrial no desenvolvimento econômico do Distrito Federal no início dos anos de 1980 era muito reduzida, tanto do ponto da produção como da geração de emprego. Essa característica refletia os resquícios da atribuição funcional da cidade, que era apenas de atividades político-administrativas. Neste período ocorreu a implantação de indústrias de materiais de construção, mais tarde a indústria engarrafadeira, de refrigerantes e cerveja, a de torrefação, moagem e empacotamento de alimentos. Implantou-se também o setor de indústria editorial e gráfica e por fim indústrias de 
características locacionais e empresas de pequeno porte como matadouros e padarias espalhados pelo Distrito Federal (PINTO,1996, p.47).

De acordo com Pinto (1996, p.47), a atividade industrial predominante era da construção civil e a de alguns materiais de construção como: cimento, madeira, metalúrgica e o ramo de alimentos e bebidas. Essas atividades geravam apenas $7 \%$ de empregos, enquanto os serviços detinham $80 \%$ da população economicamente ativa e o emprego público detinha $20 \%$ da força de trabalho.

Neste contexto, os problemas econômicos que ocorreram no país apresentaram resultados mais intensos em Brasília, pelo fato da cidade não possuir uma base econômica desenvolvida e diversificada. Todavia, sendo altamente atrativa ela continuou a receber um número alto de migrantes de várias regiões do país. Esse crescimento vertiginoso das populações urbanas transformou-se em grave problema social, o surgimento das favelas, aumento do desemprego e da violência urbana (LOPES, 1993, p.30).

A realidade socioeconômica do Distrito Federal já revelava no final da década de 1980, Brasília como um centro dinâmico da região Centro-Oeste, com uma População Economicamente Ativa (PEA) da ordem de 236 mil pessoas e a taxa de crescimento de $6 \%$ ao ano. No início da década de 1980, a população era de 1.138 .836 habitantes e a rural de 37.913 habitante. Em 1991, a população urbana passou para 1.138.836 e a rural para 85.205 habitantes. O Distrito Federal apresentava uma população 95\% urbana (SOBRAL, 1998). Cerca de $78 \%$ dos habitantes do Distrito Federal, nesse período, concentravam-se em cidades-satélites e, a esse contingente, somavam-se aproximadamente 300 mil pessoas distribuídas pelas cidades da região do Entorno ${ }^{63}$. A economia do Distrito Federal neste período esteve voltada praticamente para as atividades terciárias, ocupando quase $85 \%$ da População Economicamente Ativa.

Dessa forma é possível compreender as distorções atuais na economia do Distrito Federal, diante dependência em relação ao setor de administração pública que se mostrou incapaz de absorver o excedente de mão de obra não qualificada. Isso também tornou possível compreender a distribuição da renda no Distrito Federal e verificar que existiu uma maior concentração de renda no Plano Piloto. A Tabela 5.2 a seguir mostra a concentração da renda bruta por localidade no Distrito Federal neste período.

63 Dados do Anuário Estatístico do Distrito Federal, CODEPLAN, 1993. 
Tabela 5.2 Domicílios urbanos por classe de renda bruta média mensal (\%)

Distrito Federal - 1990

\begin{tabular}{l|l|l|l|l|l}
\hline RA's & até 3 s.m. & de 3 a 5 s.m. & de 5 a 10 s.m. & de 10 a 20 s.m. & mais de 20 s.m. \\
\hline Brasília & 3,0 & 3,4 & 10,3 & 23,8 & 59,5 \\
\hline Cruzeiro & 2,0 & 7,9 & 25,5 & 31,4 & 33,2 \\
\hline Guará & 7,5 & 10,3 & 25,4 & 29,8 & 27,0 \\
\hline N. Bandeirante & 26,8 & 15,0 & 17,8 & 18,5 & 21,9 \\
\hline Taguatinga & 17,1 & 19,1 & 27,5 & 22,6 & 13,7 \\
\hline Ceilândia & 26,8 & 34,2 & 25,5 & 11,7 & 1,8 \\
\hline Samambaia & 50,4 & 30,3 & 15,0 & 3,9 & 0,4 \\
\hline Gama & 26,3 & 27,3 & 25,0 & 15,4 & 6,0 \\
\hline Paranoá & 60,3 & 31,5 & 7,0 & 1,2 & 0,0 \\
\hline Sobradinho & 19,6 & 16,3 & 30,0 & 19,5 & 10,2 \\
\hline Planaltina & 41,5 & 24,0 & 23,1 & 6,6 & 14,6 \\
\hline Brazlândia & 21,3 & 39,6 & 31,5 & 1,2 \\
\hline Distrito Federal & 20,9 & 20,7 & 21,7 & 1,0 \\
\hline
\end{tabular}

Fonte: Pesquisa Domiciliar - CODEPLAN (1991)

RA's - Regiões Administrativas

s.m. - salários mínimos mensais

(1) Salário Mínimo (s.m.) de outubro de 1990.

O Produto Interno Bruto do Distrito Federal ${ }^{64}$, em 1995, atingiu a cifra de R\$ 17,6 bilhões (valor a preços de mercado). Apresentou crescimento real de 16,9\% no período de 1990 a 1995, com média anual de 3,2\%, tendo participação na economia brasileira de $2,7 \%$ a preços correntes e $2,9 \%$ a preços constantes. O PIB por habitante do Distrito Federal, em 1995, foi de R\$ 9.984,50 o mais elevado entre as unidades da federação, superando em 133,7\% o nacional de R \$ 4.233,70.

Analisando os valores por setor, a estimativa do PIB agropecuário está representada pelos valores adicionados das atividades da produção animal e vegetal; no industrial, as atividades da indústria de transformação, construção civil e serviços industriais de utilidade pública (água e energia elétrica); no de serviços, englobam-se as atividades de comércio, transportes, comunicações, aluguéis, instituições financeiras, administração pública e outros serviços. Em 1990, a estrutura por atividades econômicas do Distrito Federal encontrava-se da seguinte maneira: serviços, $89,1 \%$; indústria, 10,4\% e agropecuária, $0,5 \%$.

Tabela 5.3 Participação das atividades econômicas no Produto Interno Bruto - Distrito Federal - 1990-1995 (\%)

\begin{tabular}{l|c|c}
\hline Atividade econômica & $\mathbf{1 9 9 0}$ & $\mathbf{1 9 9 5}$ \\
\hline Serviços & 89,10 & 90,30 \\
\hline Indústria & 10,40 & 9,30 \\
\hline Agropecuária & 0,50 & 0,40 \\
\hline PIB & 100,00 & 100,00 \\
\hline
\end{tabular}

Fonte: adaptado CODEPLAN, 1998.

64 Os dados foram extraídos do documento "Perfil do Distrito Federal", elaborado pela Secretaria de Indústria e Comércio do Distrito Federal, 1998. 
Em 1995, sem apresentar mudanças significativas, os números eram: serviços, 90,3\%; indústria, 9,3\% e agropecuária, 0,4\%. Os dados indicavam o potencial da cidade para o terciário desenvolvido, conforme demonstrado na Tabela 5.3 acima. No período de 1990-1995, a economia local registrou crescimento de 16,9\%, superando a brasileira que foi de apenas $14,6 \%$. Esse crescimento se deveu ao desempenho dos setores agropecuário (30\%), serviços $(17 \%)$ e industrial $(14,9 \%)$.

\subsection{Território usado de Brasília até o início dos anos 1990}

O Distrito Federal em meados dos anos de 1970 entrou em sua fase de consolidação urbana com uma população superior à prevista pelo projeto inicial. As altas taxas de crescimento natural, as taxas de mortalidade e o ritmo irregular do movimento migratório fizeram com que, quase sempre os modelos de previsão demográfica no período apresentassem erros de estimativa.

Diante do crescimento da capital e do surgimento das cidades-satélites, em 1977 foi elaborado o Plano Estrutural de Organização Territorial do Distrito Federal (PEOT) que propunha através da análise das tendências de desenvolvimento dos assentamentos no Distrito Federal as diretrizes para a alocação dos novos assentamentos em seu território (PEOT, 1977, p.145).

O PEOT não deixou de ressaltar que a característica de capital políticoadministrativa atribuída a Brasília não deveria ser desconsiderada. Assim, o documento tinha como objetivo principal assegurar as condições para o desenvolvimento das funções político-administrativas da Capital da República, proporcionando à sua população condições de qualidade de vida (PEOT, 1977, p.146).

Nos anos 1970, a cidade apresentava um território caracterizado por um polinucleamento disperso, através de núcleos não articulados e distantes entre si e do Plano Piloto. A ocupação polinucleada e o pequeno porte dos núcleos reforçaram a tendência centralizadora e polarizadora do Plano Piloto, tanto em termos de oferta de empregos quanto de serviços urbanos, enfatizando a situação de dependência.

Dessa forma, a não criação de estruturas urbanas com dinamismo produtivo fez com que os núcleos continuassem a funcionar como bairros-dormitório. Do mesmo modo, as grandes distâncias entre eles forçaram a duplicação dos equipamentos urbanos com a elevação dos custos de implantação de infraestrutura. 
O Plano Estrutural de Organização Territorial do Distrito Federal (PEOT) trouxe soluções alternativas que permitam a flexibilidade destas tendo em vista o crescimento e a configuração da estrutura urbana do Distrito Federal, sendo um importante plano de ocupação para a Capital, pois procurou analisar coerentemente os fatores envolvidos na dinâmica urbana.

De acordo com o Plano Estrutural de Organização Territorial do Distrito Federal, completados dezessete anos de sua existência em 1977, o Distrito Federal possuía uma população da ordem de 900 mil habitantes prevendo-se para 1980, 1.100 mil a 1.200 mil habitantes e no ano 2000 por volta dos 2.400 mil habitantes. Segundo o plano, em 1977, o Distrito Federal já havia entrado em sua fase de consolidação urbana com a população superior à prevista no projeto inicial devido às altas taxas de crescimento natural e o ritmo irregular do movimento migratório. O Quadro 5.1 abaixo representa a evolução demográfica do Distrito Federal:

Quadro 5.1 Fases da Evolução Demográfica do Distrito Federal (1957-1977)

\begin{tabular}{c|l}
\hline Fase & \multicolumn{1}{c}{ Características } \\
\hline Primeira: 1957 - 1960 & $\Rightarrow$ "febre" da construção; \\
& $\Rightarrow$ correntes imigratórias pioneiras; \\
& $\Rightarrow$ implantação e construção de Brasília; \\
& $\Rightarrow$ primeiros núcleos urbanos periféricos; \\
& $\Rightarrow$ taxas de crescimento anual em torno de 100\%. \\
\hline Segunda: 1961 - 1964 & $\Rightarrow$ crescimento anual linear; \\
& $\Rightarrow$ decréscimo acentuado do ritmo de crescimento; \\
& $\Rightarrow$ taxas de crescimento entre 17 e 32\% ao ano. \\
\hline Terceira: $1965-1973$ & $\Rightarrow$ crescimento linear e uniforme; \\
& $\Rightarrow$ taxas de crescimento anual em torno de $10 \%$ \\
\hline Quarta: 1973 - 1977 & $\Rightarrow$ queda do ritmo de crescimento a partir de 1973; \\
& $\Rightarrow$ tendência à estabilização das taxa de crescimento \\
& anual inferiores a $10 \%$ \\
\hline
\end{tabular}

Fonte: Adaptado do PEOT (1977).

O Quadro 5.1 acima demonstra que durante os primeiros vintes anos houve um decréscimo na evolução demográfica. A Tabela 5.4 seguinte reafirma as características verificadas nas década em análise confirmando o grande crescimento nos anos 1960/1970 e depois o decréscimo que ocorre nas décadas posteriores (1970/1980, 1980/1991 e 1991/1996). 
Tabela 5.4 Evolução Demográfica do Distrito Federal (1960-1996)

População

\begin{tabular}{r|c|c|c|c|c}
\hline Década & $\mathbf{1 9 6 0}$ & $\mathbf{1 9 7 0}$ & $\mathbf{1 9 8 0}$ & $\mathbf{1 9 9 1}$ & $\mathbf{1 9 9 6}$ \\
\hline Distrito Federal (mil/hab.) & 140.164 & 537.492 & 1.176 .935 & 1.601 .094 & 1.817 .001 \\
\hline
\end{tabular}

Taxa média de crescimento anual (\%)

\begin{tabular}{r|c|c|c|c}
\hline Década & $\mathbf{1 9 6 0 / 1 9 7 0}$ & $\mathbf{1 9 7 0 / 1 9 8 0}$ & $\mathbf{1 9 8 0 / 1 9 9 1}$ & $\mathbf{1 9 9 1 / 1 9 9 6}$ \\
\hline Taxa média anual & 14,39 & 8,15 & 2,84 & 2,56 \\
\hline
\end{tabular}

Fonte: Adaptado de CODEPLAN (1996).

Retomando as proposições do Plano de Estrutural de Organização Territorial PEOT, elabora-se em 1985, o Plano de Organização Territorial do Distrito Federal - POT que se tratou fundamentalmente de uma proposta de zoneamento para os usos e ocupações do solo, com intuito de organizar os usos e ocupações do território (POT, 1985, p.14).

O POT foi o primeiro plano associado a uma proposta de zoneamento, com normas de organização urbanística tentou corrigir as distorções que o território da capital apresentava neste período. Dentre estas distorções destacavam-se, a segregação excessiva das atividades econômicas, a estratificação social e o desequilíbrio entre a oferta e demanda na distribuição dos serviços públicos essenciais.

O objetivo deste plano foi um zoneamento capaz de organizar os usos e ocupações no território usado, pressupondo por um lado desenvolver atividades humanas de acordo com as características do setor produtivo. O POT tinha por objetivo também consolidar as premissas previstas no PEOT, reconfirmando a área de expansão urbana assinalada por este e o zoneamento da área restante do Distrito Federal.

Carvalho (1999, p.17) afirma que Brasília desempenhou um papel decisivo na definição dos rumos da região Centro-Oeste, à medida que apresentou no início dos anos 1990, fatores humanos e econômicos fundamentais, não apenas como locus de onde partem os eixos dinamizadores da região, mas também como elementos decisivos na manutenção da unidade local, em torno de um projeto comum. Portanto, a sua concepção geopolítica inicial criou uma realidade geoeconômica capaz de inaugurar um novo padrão de desenvolvimento regional endógeno para o Centro-Oeste.

De acordo com Sobrinho et al (2011, p.06) concepção urbanística de Brasília trouxe em seu planejamento um projeto de modernização nacional. Com uma localização 
geopolítica privilegiada, Brasília irradiaria o desenvolvimento para a região Centro-Oeste ${ }^{65}$ e que assumiria apenas as funções político-administrativas, sendo o processo migratório absorvido pelos núcleos urbanos já existentes ou recém-criados.

De acordo com Paviani (1985, p.65) a maior metrópole terciária brasileira, em termos de não apoiar sua base econômica na atividade industrial, concentrou grande gama de serviços que sustentam sua vida econômica, marcada pela complexidade de suas funções terciárias e pela crescente inter-relação espacial, tanto em seu interior, como na região geoeconômica à sua volta, nos Estados de Goiás e Minas Gerais. Vejamos o desenvolvimento do setor terciário e a sua emergência como atividade econômica principal em Brasília na décadas seguintes.

\subsection{Cenário produtivo de Brasília a partir do final dos anos 1990}

Mesmo diante dos problemas ocasionados pela concentração de renda e da incapacidade de absorver o excedente de mão de obra, a cidade no final dos anos 1990, não diferente das demais metrópoles nacionais, buscava adaptar-se aos processos da acumulação flexível. Para isso, reunia algumas características socioeconômicas relevantes: a renda per capita alta de sua população; o Complexo de Pesquisa que era o quinto do país; a aproximação privilegiada do Governo Federal; a boa infraestrutura e o traçado urbano moderno, aliados a excelente posição geográfica (NASCIMENTO, 1996, p.7)

Em 1996, o Distrito Federal apresentava os seguintes indicadores: população atendida com água encanada, 97\%; população urbana com acesso a esgotamento sanitário 84\%; população urbana com coleta de lixo 97,5\%; área de cobertura vegetal por habitante $100 \mathrm{~m}^{2}$; cobertura vacinal total de crianças menores de 1 ano (tuberculose, pólio e tríplice); número de habitantes por médico - 333; número de habitantes por enfermeiro - 165 ; domicílios servidos por energia elétrica 100\%; taxa de mortalidade geral por 1000 nascidos vivos $4,4 \%{ }^{66}$

Para Maciel apud (CIDADE, 1998), a estratégia para diversificar o perfil das atividades produtivas na cidade encontrou subsídios na potencialização dos recursos humanos, institucionais e tecnológicos que a capital dispunha, rumo a uma integração das novas tendências da acumulação flexível como a manifestação de especializações com

\footnotetext{
${ }^{65}$ Como na Teoria dos Polos de Crescimento de Perroux. Ver discussão no Capítulo 02.

${ }^{66}$ Os dados foram extraídos do documento "Perfil do Distrito Federal", elaborado pela Secretaria de Indústria e Comércio do Distrito Federal, 1998.
} 
potencial para ocupar nichos de mercado, como a informática, gemologia e a biotecnologia; o crescimento do número de instituições de ensino superior, que permitiu a formação de um número crescente de pessoas, enquanto favorecia a constituição de parcerias com as empresas e; a existência de uma população com idade média baixa e um nível de instrução relativamente elevado.

A tendência de concentração de empregos no Plano Piloto continuou nas décadas seguintes, porém ressaltando-se a existência das propostas do Plano Diretor de Ordenamento Territorial - PDOT (1997) a criação de centros nas cidades-satélites de alocação de serviços deslocando dessa forma a centralidade presente no Plano Piloto no que diz respeito à geração de empregos e serviços.

No ano de 2011, o PIB do Distrito Federal correspondeu a 4\% do PIB nacional alcançando em valores correntes, $\mathrm{R} \$ 164,5$ bilhões e a sétima posição entre as maiores economias do país, conforme a Tabela 5.5. O Gráfico 5.1 mostra a variação do PIB-DF em relação ao PIB-Brasil na série histórica (2003-2011). O crescimento do PIB-DF foi impulsionado pela atividade econômica em torno de 4,1\%, superior à média nacional de $2,7 \%$ no mesmo período e refletiu o desempenho das variações positivas de $3,9 \%$ do valor adicionado a preços básicos e de 5,6\% dos impostos sobre produtos líquidos de subsídios. O crescimento da agropecuária foi de $43,1 \%$, da indústria $9,8 \%$ e de serviços $3,4 \%{ }^{67}$.

Gráfico 5.1 Variação em volume do PIB - Brasil e DF

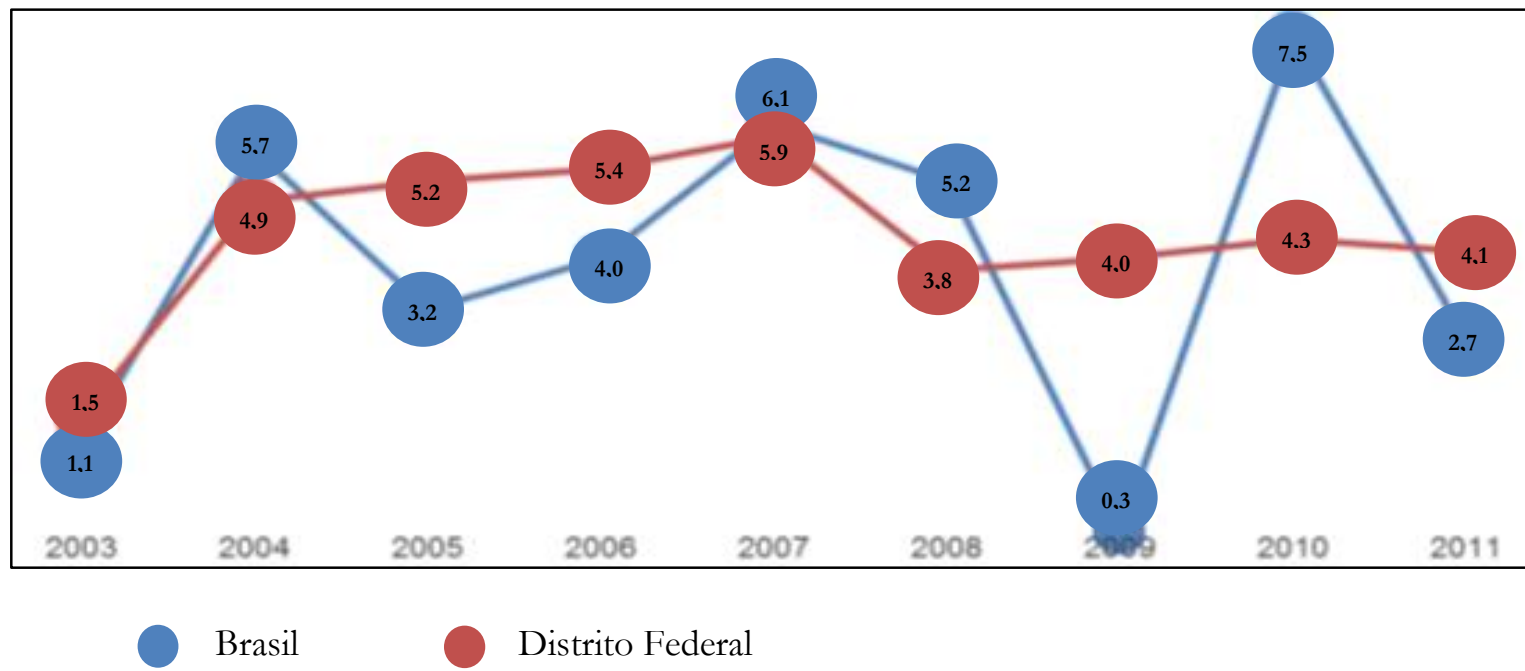

Fonte: A partir de IBGE e CODEPLAN (2013).

${ }^{67}$ CODEPLAN, 2013. 
De acordo com a CODEPLAN (2013) o valor adicionado bruto do setor agropecuário atingiu $\mathrm{R} \$ 501$ milhões, e registrou crescimento real de 43,1\% conforme mostra a Tabela 5.5, após apresentar redução de 27,5\% em 2010. Em âmbito nacional a atividade evoluiu 3,9\%. Segundo dados da pesquisa Produção Agrícola Municipal (PAM), do IBGE, as principais culturas agrícolas no Distrito Federal tiveram acréscimo na produção com aumento de produtividade o que justificaria o crescimento real observado no período. No entanto a participação relativa do setor agropecuário na estrutura produtiva do Distrito Federal permaneceu inexpressiva de $0,3 \%$ e impactou pouco no índice geral conforme mostra a Tabela 5.6.

Tabela 5.5 Produto Interno Bruto e valor adicionado bruto -

Distrito Federal 2003-2011 (R\$ milhão)

\begin{tabular}{l|l|l|l|l}
\hline Atividade econômica & $\mathbf{2 0 0 3}$ & $\mathbf{2 0 0 4}$ & $\mathbf{2 0 0 5}$ & $\mathbf{2 0 0 6}$ \\
\hline Serviços & 51.903 & 58.477 & 65.742 & 74.796 \\
\hline Indústria & 4.055 & 4.287 & 5.323 & 5.105 \\
\hline Agropecuária & 277 & 198 & 175 & 169 \\
\hline Valor adicionado Bruto & 56.236 & 62.936 & 71.240 & 80.070 \\
\hline PIB & 63.105 & 70.124 & 80.527 & 89.629 \\
\hline
\end{tabular}

\begin{tabular}{l|l|l|l|l|l}
\hline Atividade econômica & $\mathbf{2 0 0 7}$ & $\mathbf{2 0 0 8}$ & $\mathbf{2 0 0 9}$ & $\mathbf{2 0 1 0}$ & $\mathbf{2 0 1 1}$ \\
\hline Serviços & 83.658 & 96.751 & 108.251 & 124.179 & 134.790 \\
\hline Indústria & 5.879 & 6.567 & 7.657 & 8.721 & 9.178 \\
\hline Agropecuária & 262 & 432 & 542 & 335 & 501 \\
\hline Valor adicionado Bruto & 89.799 & 103.749 & 116.450 & 133.235 & 144.469 \\
\hline PIB & 99.946 & 117.572 & 131.487 & 149.906 & 164.482 \\
\hline
\end{tabular}

Fonte: CODEPLAN, 2013.

Ainda neste período, o Distrito Federal manteve suas características socioeconômicas peculiares: renda per capita elevada; índice elevado de emprego formal, pouca expressividade dos setores agropecuário e industrial e presença marcante da administração pública, sendo que o setor terciário respondeu por 93,3\% do PIB, em 2011, com R $\$ 134,8$ bilhões, demonstrado na Tabela 5.6.

Segundo a CODEPLAN (2013) o crescimento do setor de serviços foi de 3,4\% em relação ao ano anterior e foi superior à média nacional $(2,7 \%)$. Destaca-se a atividade de serviços de informação com crescimento de $25,9 \%$ que também foi a atividade que registrou a maior taxa de crescimento $(4,9 \%)$ no Brasil. Outras atividades que contribuíram 
para o resultado foram a intermediação financeira, os seguros e previdência complementar e serviços relacionados $(6,1 \%)$, transportes, armazenagem e correio $(4,5 \%)$ e atividades imobiliárias e aluguéis.

Tabela 5.6 Participação das atividades econômicas no valor adicionado bruto Distrito Federal - 2003-2011 (\%)

\begin{tabular}{l|l|l|l|l}
\hline Atividade econômica & $\mathbf{2 0 0 3}$ & $\mathbf{2 0 0 4}$ & $\mathbf{2 0 0 5}$ & $\mathbf{2 0 0 6}$ \\
\hline Serviços & 92,3 & 92,9 & 92,3 & 93,4 \\
\hline Indústria & 7,2 & 6,8 & 7,5 & 6,4 \\
\hline Agropecuária & 0,5 & 0,3 & 0,2 & 0,2 \\
\hline Valor adicionado Bruto & 100.0 & 100.0 & 100.0 & 100.0 \\
\hline PIB & 92,3 & 92,9 & 92,3 & 93,4 \\
\hline
\end{tabular}

\begin{tabular}{l|l|l|l|l|l}
\hline Atividade econômica & $\mathbf{2 0 0 7}$ & $\mathbf{2 0 0 8}$ & $\mathbf{2 0 0 9}$ & $\mathbf{2 0 1 0}$ & $\mathbf{2 0 1 1}$ \\
\hline Serviços & 93,2 & 93,3 & 93,0 & 93,2 & 93,3 \\
\hline Indústria & 6,5 & 6,3 & 6,6 & 6,5 & 6,4 \\
\hline Agropecuária & 0,3 & 0,4 & 0,5 & 0,3 & 0,3 \\
\hline Valor adicionado Bruto & 100.0 & 100.0 & 100.0 & 100.0 & 100.0 \\
\hline PIB & 93,2 & 93,3 & 93,0 & 93,2 & 93,3 \\
\hline
\end{tabular}

Fonte: CODEPLAN, 2013.

No ano de 2011, a população correspondeu a 2,610 milhões de habitantes e o PIB per capita ficou na ordem de R \$63.020,02, ressaltando-se que este correspondeu a praticamente o triplo do PIB per capita nacional de $\mathrm{R} \$ 21.535,65$ e quase o dobro do observado em São Paulo de R \$32.449,06, o segundo maior do país ${ }^{68}$.Como resultado das ações de políticas socioeconômicas, a estrutura por atividades econômicas no Distrito Federal encontrava-se do seguinte modo no valor adicionado bruto: serviços, 93,3\%; indústria, 6,4\% e; agropecuária, 0,3\%. Observa-se mais uma vez o predomínio quase que completo do setor de serviços e a inexpressiva participação do setor agropecuário conforme a Tabela 5.6.

A realidade socioeconômica do Distrito Federal manteve-se demonstrando que a sua participação no PIB e no valor adicionado bruto no Brasil entre 2003 e 2011, foi praticamente constante em termos percentuais, na ordem de $4,0 \%$ e $4,1 \%$, respectivamente como se observa na Tabela 5.7.

${ }^{68}$ CODEPLAN, 2013. 
Tabela 5.7 Participação do Distrito Federal no Produto Interno Bruto e no valor adicionado bruto no Brasil - 2003-2011 (\%)

\begin{tabular}{l|l|l|l|l}
\hline Atividade econômica & $\mathbf{2 0 0 3}$ & $\mathbf{2 0 0 4}$ & $\mathbf{2 0 0 5}$ & $\mathbf{2 0 0 6}$ \\
\hline Serviços & 5,4 & 5,6 & 5,5 & 5,6 \\
\hline Indústria & 1,0 & 0,9 & 1,0 & 0,9 \\
\hline Agropecuária & 0,3 & 0,4 & 0,2 & 0,2 \\
\hline Valor adicionado Bruto & 3,8 & 3,8 & 3,9 & 3,9 \\
\hline PIB & 3,7 & 3,6 & 3,8 & 3,8 \\
\hline
\end{tabular}

\begin{tabular}{l|l|l|l|l|l}
\hline Atividade econômica & $\mathbf{2 0 0 7}$ & $\mathbf{2 0 0 8}$ & $\mathbf{2 0 0 9}$ & $\mathbf{2 0 1 0}$ & $\mathbf{2 0 1 1}$ \\
\hline Serviços & 5,5 & 5,7 & 5,7 & 5,8 & 5,7 \\
\hline Indústria & 0,9 & 0,9 & 1,0 & 1,0 & 0,9 \\
\hline Agropecuária & 0,2 & 0,3 & 0,3 & 0,2 & 0,3 \\
\hline Valor adicionado Bruto & 3,9 & 4,0 & 4,2 & 4,1 & 4,1 \\
\hline PIB & 3,8 & 3,9 & 4,1 & 4,0 & 4,0 \\
\hline
\end{tabular}

Fonte: CODEPLAN, 2013.

A mesma racionalidade dos dados em relação aos dados do Brasil é observada na Tabela 5.8, quando verificada a participação do Distrito Federal no Produto Interno Bruto, de $41,5 \%$, e de $41,1 \%$ no valor adicionado bruto quando referente ao Centro-Oeste. Como mencionado anteriormente, o setor de serviços corresponde à atividade econômica mais importante do Distrito Federal. Dentre os setores mereceram destaque o setor de serviços de informação com taxa de crescimento de 25,9\% (CODEPLAN, 2015).

Tabela 5.8 Participação do Distrito Federal no Produto Interno Bruto e no valor adicionado bruto no Centro-Oeste - 2003-2011 (\%)

\begin{tabular}{|c|c|c|c|c|c|}
\hline Atividade econômica & & 2003 & 2004 & 2005 & 2006 \\
\hline Serviços & & 53,6 & 53,7 & 54,0 & 54,2 \\
\hline Indústria & & 20,9 & 17,1 & 20,2 & 18,3 \\
\hline Agropecuária & & 1,4 & 0,9 & 0,9 & 1,0 \\
\hline Valor adicionado Bruto & & 41,5 & 40,1 & 42,5 & 44,0 \\
\hline PIB & & 41,2 & 40,0 & 42,3 & 43,4 \\
\hline Atividade econômica & 2007 & 2008 & 2009 & 2010 & 2011 \\
\hline Serviços & 53,5 & 53,4 & 53,8 & 54,4 & 54,2 \\
\hline Indústria & 18,6 & 18,1 & 18,0 & 17,3 & 16,2 \\
\hline Agropecuária & 1,2 & 1,6 & 1,8 & 1,1 & 1,5 \\
\hline Valor adicionado Bruto & 42,9 & 42,3 & 42,4 & 43,1 & 41,1 \\
\hline PIB & 42,4 & 42,1 & 42,3 & 42,8 & 41,5 \\
\hline
\end{tabular}

Fonte: CODEPLAN, 2013. 
Importante mencionar que esses dados verificados no Distrito Federal atraíram uma gama de investimentos estrangeiros ao mesmo tempo em que desenvolveram a atividades econômicas dos setores agropecuário e de serviços. O setor de serviços se consolidou como a atividade econômica mais importante no Distrito Federal e ainda provocou uma demanda por serviços mais especializados tipicamente de um terciário avançado.

\subsection{Brasília Metropolitana a partir do final dos anos 1990}

Brasília no final dos anos de 1990 apresentava características que demonstravam o seu papel de conexão no território nacional. A sua posição estratégica foi fundamental para o desenvolvimento e avanços na integração das regiões Centro-Oeste e Norte do país. Ao mesmo tempo em que seu território reunia condições de consolidação de seu papel de metrópole nacional com atividades típicas da sua função inerente a de Capital e outras de um setor terciário avançado.

A definição de Brasília como metrópole nacional pode ser identificada através de sua área de influência realizada pela REGIC - IBGE $^{69}$ (2007). A capital no final dos anos de 1990 passou a ter influência na configuração territorial brasileira pela sua posição estratégica. Além da sua função de centro administrativo federal a cidade também vem se destacando como importante conector de atividades comerciais de abrangência nacional.

De acordo com a REGIC (2007), a rede metropolitana de Brasília, em comparação com as demais redes, apresenta apenas $2,5 \%$ da população, concentrando 4,3\% do Produto Interno Bruto (PIB). A Figura 5.1 mostra a área de influência direta de Brasília a partir de dados da REGIC de 2007. A extensão de sua rede de influência direta é relativamente pequena, concentrando-se a oeste da Bahia ao noroeste de Minas Gerais e o nordeste do Goiás.

\footnotetext{
${ }^{69}$ A REGIC - Regiões de Influência das Cidades é elaborada pelo IBGE para levantamento de dados para o planejamento e gestão das municipalidades brasileiras (IBGE, 2015).
} 


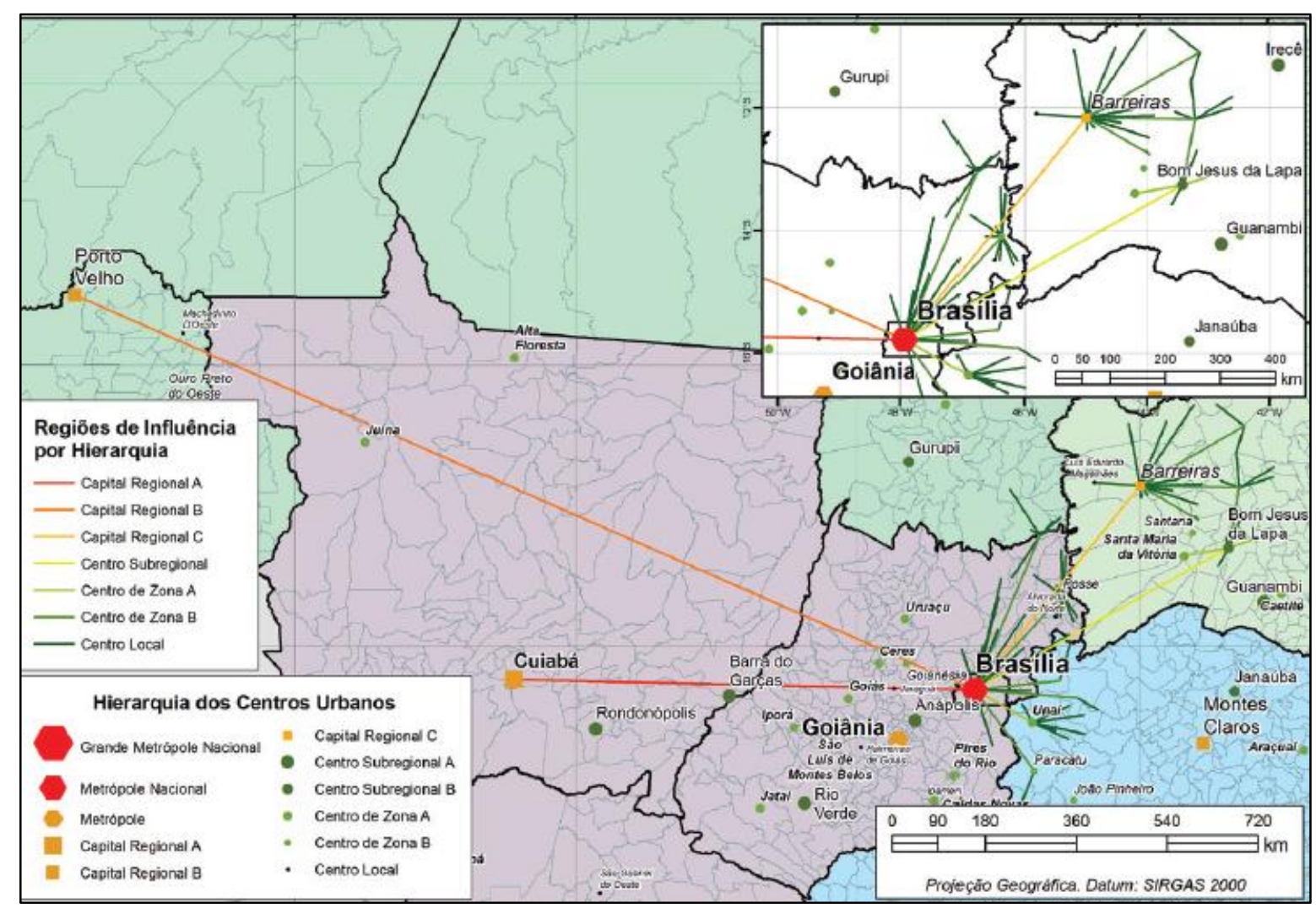

Figura 5.1 Área de influência direta de Brasília

A Figura 5.1 mostra a área de influência direta de Brasilia a partir de dados da REGIC de 2007.

Fonte: IBGE (2015)

Apesar da pouca representatividade em termos de abrangência para uma metrópole nacional, quando são comparados os valores do PIB, a rede de Brasília apresenta alta concentração no centro (o Distrito Federal) que apresenta $72 \%$ da população e 90,3\% do PIB da rede metropolitana (IBGE, 2008). De acordo com Holanda; Ribeiro (2015, p. 43) a rede metropolitana de Brasília é de fundamental importância para a integração do território nacional por dois motivos. O primeiro deles é a sua posição estratégica central no território o que lhe permite a conexão entre as demais onze redes definidas pela REGIC. A Figura 5.2 Apresenta as principais ligações da metrópole brasiliense com outros centros. O segundo motivo, por concentrar as principais instituições públicas federais é também o centro de tomada de decisões e planejamento do país. 


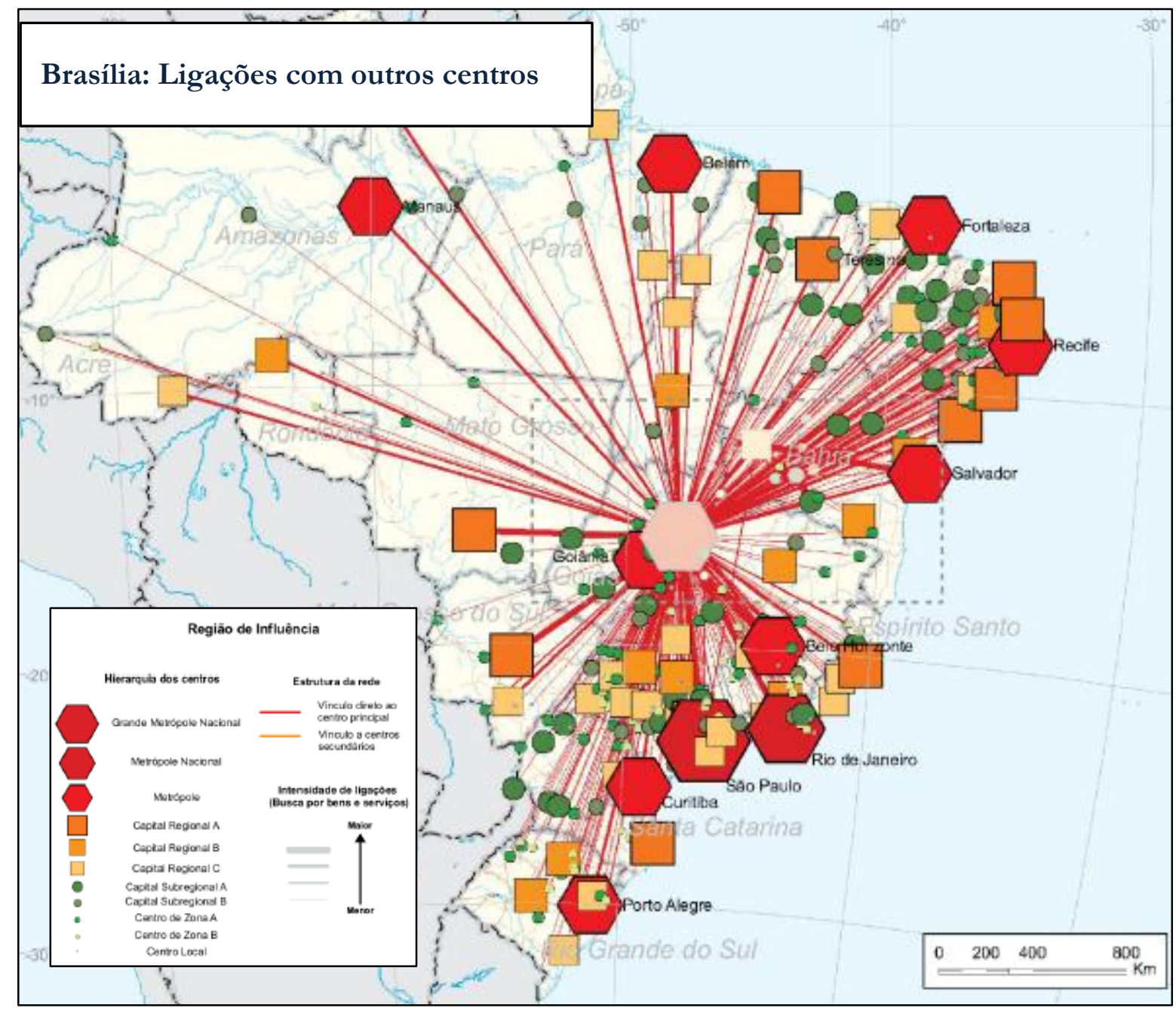

Figura 5.2 Brasília: metrópole nacional

Mostra as ligações de Brasília com outros centros no país e a sua posição geopolitica estratégica.

Fonte: IBGE (2015)

Holanda; Ribeiro (2015, p. 42) apontam ainda que a sua participação na rede nacional identifica a sua principal função que é a de centro de gestão pública. Mas a REGIC aponta também a sua emergência no desenvolvimento de atividades comerciais devida a sua posição estratégica. Todavia, o centro da sua rede metropolitana - o Distrito Federal vem enfrentando pressões por atendimento da demanda de serviços de seu entorno imediato tornando necessário formular planos de desenvolvimento socioeconômicos que considerem a realidade de sua rede como um todo.

Partindo de uma proposta mais ampla e com o objetivo de uma maior integração dos espaços urbanos, surgiu o Plano Diretor de Ordenamento Territorial PDOT em 1997. Assim, passou-se a considerar a dinâmica de crescimento de Brasília, mas também das cidades-satélites e também do próprio entorno imediato do Distrito Federal. O 
plano previa a preservação das características urbanísticas do Plano Piloto e as limitações na capacidade de suporte ambiental do Distrito Federal, tomadas como referências básicas para qualquer ação no território.

O Plano Diretor de Ordenamento Territorial - PDOT (1997) objetivava identificar as possíveis alternativas econômicas para o Distrito Federal, com vistas ao incentivo, indução ou orientação aos agentes públicos e privados, numa perspectiva de desenvolvimento sustentável, levando em consideração não apenas o uso racional do meio ambiente urbano e rural.

O plano preconizava que o perfil do mercado consumidor local, a natureza de mão de obra, do tipo de empreendedor, a disponibilidade de espaços físicos, a legislação de uso e ocupação do solo, o potencial limitado dos recursos hídricos e a localização geográfica, dentre outros, eram fatores de relevância a serem considerados para o desenvolvimento de atividades produtivas no território.

Entretanto, ainda que se possa eleger certos tipos de atividades sob diversas hipóteses favoráveis, não há garantias de que elas venham a ser implantadas conforme as metas estabelecidas ou conforme o setor econômico identificado. A existência de determinados atributos locais favoráveis ao desenvolvimento produtivo pretendido não garante, ainda, que a dinamização da economia possa vir a superar os limites do mercado local.

Dessa forma, o plano pretendia em suas diretrizes viabilizar o desenvolvimento econômico, buscando alternativas que otimizassem a utilização das características locais, seja produtivo ou de consumo. Estabelecia a curtos e médios prazos, condições favoráveis ao desenvolvimento de atividades intensivas na utilização de mão de obra não qualificada, constituindo alternativas de emprego para a população já residente no Distrito Federal.

As políticas de industrialização do Distrito Federal segundo o plano deveriam estar inseridas numa perspectiva de desenvolvimento regional, abrangendo a região geoeconômica do Distrito Federal ou mesmo área geográfica mais ampla. Na inexistência de uma política definida a nível nacional, a iniciativa de uma ação conjunta e a definição de objetivos estratégicos deveriam partir necessariamente, dos Estados e municípios envolvidos (PDOT, 1997).

O alto grau de absorção da mão de obra pelo setor terciário apontava para a necessidade de sua reafirmação na economia do Distrito Federal. A configuração do Plano Piloto enquanto cidade administrativa, assim como a necessidade de preservação das suas 
características urbanas, evidenciavam o deslocamento do dinamismo econômico e do crescimento urbano.

O desenvolvimento de atividades do setor secundário deveria ocorrer de acordo com as condições locais; preferencialmente na região sudoeste do Distrito Federal, onde se concentram condições mais favoráveis. Nas regiões mais restritas, tal como o eixo Plano Piloto - Sobradinho, deveriam ser desenvolvidas atividades compatíveis com a sua capacidade de suporte, tal como as de inovações não intensivas no uso de recursos naturais escassos e não geradores de deslocamentos em massa para a região (PDOT, 1997).

De acordo com Paviani (1994, p.02), a cidade enquanto conduto sócio-espacial refletiu as mudanças conforme a atuação das forças que impulsionaram o seu processo de urbanização. Neste sentido mudam as suas estruturas, funções e formas espaciais que se tornam obsoletas com o passar do tempo, necessitando de renovação e/ou alterações. Daí porque, no decurso de algumas dezenas de anos, certos fixos urbanos poderão não resistir às pressões da sociedade, emergindo formas/funções ou estruturas novas.

No planejamento urbano de Brasília, foi enfatizado o zoneamento funcional, privilegiando-se a dominação da natureza, com a construção de uma nova paisagem e submissão do homem a essa racionalidade imposta, como a melhor alternativa tecnicamente elaborada e cientificamente respaldada. Por suas próprias características, esse planejamento foi seletivo do ponto vista social e espacial, excluindo lugares, pessoas e atividades, criando no seu bojo as desigualdades espaciais e os 'excluídos' (FERREIRA; PENNA, 1996, p.193).

Estudos sobre Brasília, como o de Sousa (1983), Paviani (1987,1991), Colela (1991), além dos esboços técnicos que fundamentam o Plano de Estrutural de Organização Territorial- PEOT, o Plano de Ocupação Territorial- POT, o Plano de Organização e Uso do Solo- POUSO, demonstraram a condição de metrópole da cidade. A realidade de Brasília é ser capital de uma metrópole que se constituiu no Distrito Federal, cujos limites vão de Ceilândia ao Gama, passando por Taguatinga, Núcleo Bandeirante, Águas Claras, Riacho Fundo, Samambaia, do Recanto das Emas, Guará, Gama, Santa Maria e se estendem às cidades, aos parques e aos jardins limítrofes, como Novo Gama, Valparaízo, Cidade Ocidental, Jardim Ingá e outros em Goiás. Todas essas cidades, parques e jardins goianos foram comercializados pela iniciativa privada, tanto em razão da relativa saturação das cidades-satélites, como da política restritiva à criação de loteamentos no Distrito Federal. 
Dessa forma, o Plano Diretor de Ordenamento Territorial - PDOT (1997) foi uma proposta para a resolução dos conflitos existentes na dinâmica territorial do Distrito Federal. A formação de comissões de discussão, reuniões regionais e a participação da comunidade em seu processo de elaboração fizeram do documento o diagnóstico necessário para a solução dos principais problemas que envolvem a metrópole.

A organização territorial da capital neste período coincide com a sua consolidação/ formação metropolitana, composta por um centro polarizador e um longo espaço periférico desconcentrado. Resende; Cidade (2013, p. 14) afirmam que as enraizadas restrições de acesso à moradia no núcleo polarizado e a especulação /valorização imobiliária no Distrito Federal provocaram um movimento de adensamento do tecido urbano periférico.

Como resultado disto surgiram os modelos habitacionais sob a forma de condomínios habitacionais horizontais para a classe média e alta no Distrito Federal e loteamentos precários para as classes de baixa renda nos municípios goianos do Entorno. Estes loteamentos oriundos do parcelamento de terras em áreas rurais sem controles fundiários, urbanístico e ambientais foram localizados principalmente próximos aos eixos viários de ligação a capital (RESENDE; CIDADE, 2013, p. 14). Dessa forma, a capital apresentou neste período uma organização espacial monocêntrica, polinucleada e descontínua. O centro polarizador manteve suas áreas residenciais com elevada qualidade ambiental contrastando com os núcleos residenciais de baixa renda espalhados num cinturão verde sem atividades econômicas das cidades-satélites.

Neste contexto, foi criada pela Lei Complementar $n^{\circ}$ 94, de 19 de fevereiro de 1998, a Região Integrada de Desenvolvimento do Distrito Federal e Entorno (RIDE-DF), uma região de desenvolvimento econômico, tendo como objetivo principal os serviços públicos ao Distrito Federal, Goiás e Minas Gerais e aos municípios que a integram ${ }^{70}$.

De acordo com Holanda; Ribeiro (2015, p. 47) a RIDE-DF por ser constituída de dois Estados e o Distrito Federal, sua gestão metropolitana ocorre em nível federal o que tem dificultado a efetivação dos processos de desenvolvimento da região. Afirmam os

\footnotetext{
${ }^{70}$ A Ride foi criada pela Lei Complementar $n^{\circ}$ 94, de 19 de fevereiro de 1998, regulamentada pelo Decreto $\mathrm{n}^{\circ} 2.710$, de 04 de agosto de 1998 e modificada pelo Decreto $\mathrm{n}^{\circ}$ 7.469, de 04 de maio de 2011. A Ride, também chamada Ride - DF, é integrada pelo Distrito Federal e pelos seguintes municípios: Abadiânia (GO), Água Fria de Goiás (GO), Águas Lindas de Goiás (GO), Alexânia (GO), Cabeceiras $(\mathrm{GO})$, Cidade Ocidental (GO), Cocalzinho de Goiás (GO), Corumbá de Goiás (GO), Cristalina (GO), Formosa (GO), Luziânia (GO), Mimoso de Goiás (GO), Novo Gama (GO), Padre Bernardo (GO), Pirenópolis (GO), Planaltina (GO), Santo Antônio do Descoberto (GO), Valparaíso (GO), Vila Boa (GO); e Buritis (MG), Cabeceira Grande (MG) e Unaí (MG) (SUDECO,2013a).
} 
autores que este desenvolvimento não ocorreu e a RIDE-DF somente reforçou a centralidade do Distrito Federal e a dependência dos demais municípios em relação a este.

A questão é que essa polarização do Distrito Federal somente fez aumentar a demanda nos diversos serviços públicos. Por um lado, provoca uma crise no oferecimento de serviços públicos no Distrito Federal como saúde, educação e segurança, como acentua as precárias condições dos demais municípios pertencentes à RIDE-DF. A Figura 5.3 mostra as duas definições para a Brasília metropolitana, uma composta pelos municípios de influência direta em seu entorno imediato (AMB) e outra mais abrangente a RIDE-DF.

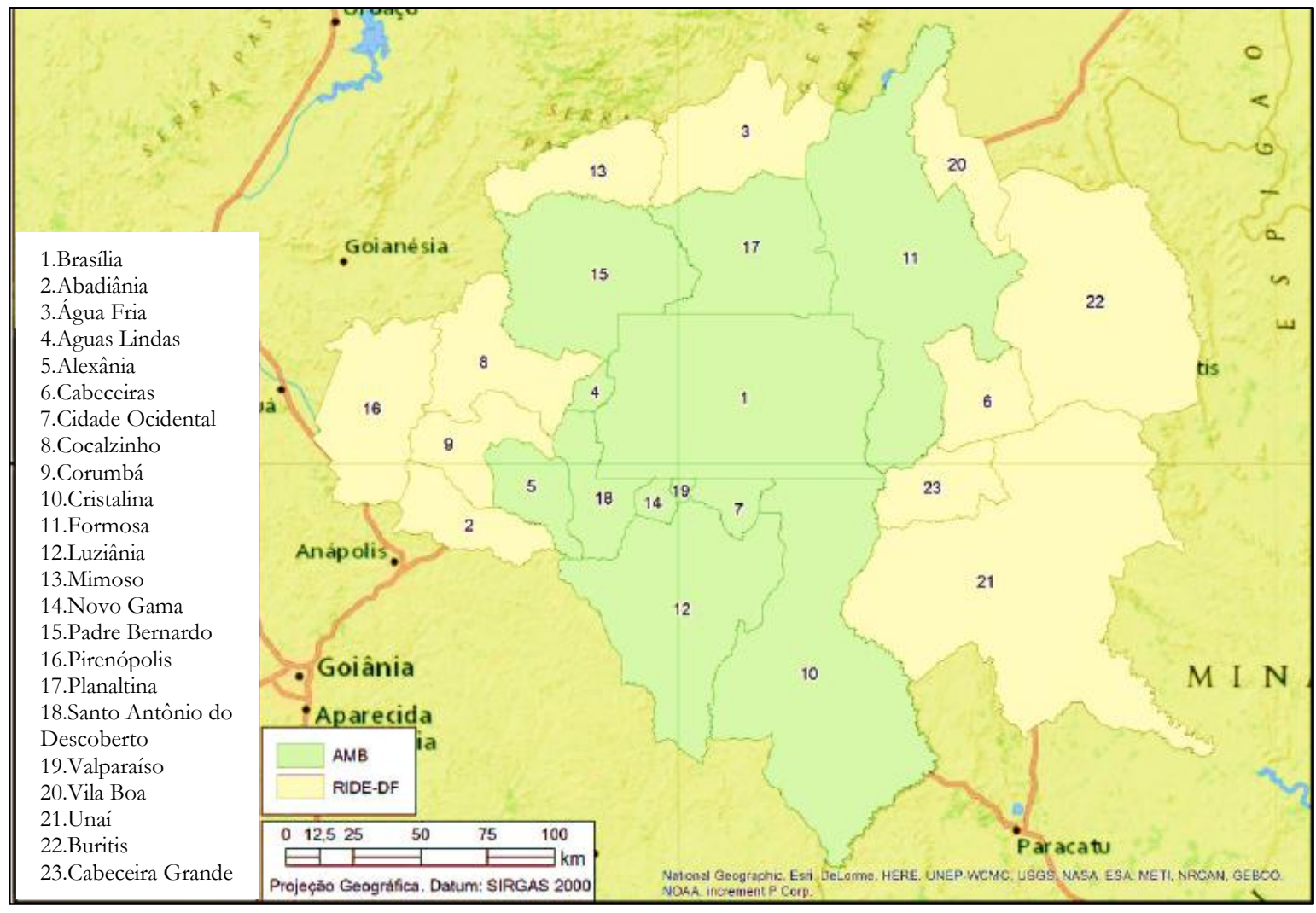

Figura 5.3 Brasília Metropolitana: AMB e RIDE-DF

Mostra as duas definiçoes para a Brasilia Metropolitana, uma composta pelos municípios de influência direta em seu entorno imediato (AMB) e outra mais abrangente a RIDE-DF.

Fonte: Holanda; Ribeiro (2015).

Sob a ótica do planejamento, a primeira década do século foi marcada pela discussão em torno da delimitação da área metropolitana do Brasília. De acordo com Schvasberg (2012, p. 26) o crescimento metropolitano na última década associado às novas centralidades, necessidades mercadológicas, as mudanças na estrutura políticoadministrativa do GDF e dos municípios da Área Metropolitana de Brasília (AMB), da ocupação das Áreas de Proteção Ambiental (APA) do São Bartolomeu e do Descoberto 
demanda uma política urbana metropolitana que o Plano Diretor de Ordenamento Territorial - PDOT de 1996 não contemplou.

Os planos de ordenamento territorial de Brasília estabeleceram o controle da expansão urbana e as medidas de preservação do meio ambiente. De acordo com Peluso; Cidade (2014, p. 08) a criação da Área de Proteção Ambiental do Planalto Central estabeleceu parâmetros para o uso racional dos recursos naturais e a proteção do patrimônio ambiental e cultural do Distrito Federal e do Estado de Goiás. Nesse sentido, por meio do Zoneamento Ecológico Econômico, o Governo do Distrito Federal criou áreas de proteção ambiental, áreas de relevante interesse ecológico, parques e reservas ecológicas $^{71}$ que são importantes instrumentos de organização do território usado e a manutenção dos recursos hídricos.

O novo Plano Diretor de Ordenamento Territorial - PDOT, de 2009, partiu de uma visão geral e integrada sobre o território da metrópole numa proposta de macrozoneamento em três áreas, urbana, rural e de proteção integral. O plano procurou estabelecer diretrizes para estruturar polos dinâmicos nas regiões administrativas, numa tentativa de descentralização das atividades e a diminuição das dependências destas em relação ao centro. Suas diretrizes visavam orientar instrumentos de política urbana, todavia os efeitos dessas ainda não são perceptíveis no tecido urbano.

O Governo do Distrito Federal agiu numa redução gradual dos serviços na tentativa de transferência para o setor privado de todos aqueles serviços que não havia necessidade absoluta de serem executados pelo Estado, correspondendo tipicamente na posição de um governo urbano neoliberal que parte da premissa de que o investimento privado quando é fomentado pelo mercado, produz riqueza e gera trabalho e consequentemente o bem-estar da cidade. Inserida no contexto dos processos produtivos e espaciais das metrópoles brasileiras, Brasília, com a emergência do setor de serviços apresenta formas metropolitanas que combinam adensamento disperso e policentrismo, ao mesmo tempo em que acentua o caráter concentrador da área central.

A expansão do setor de serviços na capital, a propagação de novas tecnologias e a ampliação do setor imobiliário apontam uma tendência a uma nova reorganização territorial. Reconhecendo uma concentração dos serviços no núcleo da cidade central (Plano Piloto) verifica-se uma tendência à criação de novas áreas de expansão periférica, sejam elas voltadas à instalação de condomínios horizontais para a classe média ao longo

\footnotetext{
${ }^{71}$ O Mapa 6.1 do Macrozoneamento do Distrito Federal no Capítulo 06, apresentará as macrozonas de proteção integral do Distrito Federal.
} 
de eixos viários importantes ou para a implementação de centros de negócios, serviços e de produção de novas tecnologias. As ações de gestão do território por meio de diversos planos de ordenamento não levaram em consideração a segregação espacial, a concentração das atividades econômicas na área central e nem o crescimento populacional exacerbado no entorno imediato da capital. Como consequência houve o acirramento das disparidades na dinâmica urbana de Brasília.

De acordo com Ferreira; Steinberger (2006), Brasília foi concebida sob um modelo de gestão considerado inovador e com suas especificidades acabou repetindo as tendências gerais do processo metropolitano brasileiro. Ainda segundo as autoras, existem dois modelos de gestão territorial que vem sendo construídos em Brasília, um de concepção ideal que corresponde à dimensão estatizada do território e o outro de ajuste à realidade, que corresponde à dimensão privatizada do território.

Do ponto de vista da estruturação espacial, o período em análise apresenta um processo de adensamento e expansão territorial metropolitana e ao mesmo tempo um processo de dispersão em direção ao Entorno (municípios). A criação da RIDE em 1998, confirma este processo, reconhecendo que algumas aglomerações urbanas ultrapassam os limites de unidades federativas diferentes tornando-se necessário ofertar serviços públicos comuns em diversas áreas. A RIDE representa o reconhecimento de um fluxo constante de pessoas, atividades econômicas e urbanização entre o Distrito Federal e os municípios imediatos.

Por outro lado, existe ainda a tentativa de consolidação da AMB para uma melhor distribuição desses serviços. A falta de definição da AMB tem gerado um impasse na elaboração de uma política urbana que contemple realmente a dinâmica territorial e metropolitana da capital. Para Schvasberg (2012, p. 27), mesmo com a implementação de um eventual Plano Diretor de Ordenamento Territorial - PDOT (2009) atualizado o mesmo não seria capaz de solucionar os problemas presentes na $\mathrm{AMB}$, pois ficaria restrito ao território do Distrito Federal, como os demais planos anteriores.

De acordo com Resende; Cidade (2013, p. 14) essa dinâmica com outras localidades do Entorno do Distrito Federal provoca processos intensos que interferem diretamente nas áreas rurais (novas ocupações/destinações), no ambiente natural e na área urbana. A expansão da área urbanizada do núcleo em direção a estas localidades evidencia uma tendência à dispersão e ampliação do espaço construído e ainda potencializa conurbações, tipicamente características de metrópoles. 
Enquanto metrópole, a capital vem modificando seu tecido urbano/rural, evidenciando uma reorganização territorial. Apesar da forte polarização do núcleo (Plano Piloto), surgem novas centralidades, como Taguatinga e Gama. Resende; Cidade (2013, p. 15) apontam para um novo padrão espacial que vem se estruturando em direção a uma conurbação acompanhando os principais eixos rodoviários, em especial do eixo sudoeste, um movimento de expansão urbana marcado por dispersão e fragmentação territorial.

Brasília, foi concebida em torno de uma organização monocêntrica e polinucleada e com um tecido urbano descontínuo. Todavia, o seu desenvolvimento e as novas dinâmicas urbanas e centralidades, impostas pelo seu entorno imediato evidenciam um movimento de dispersão e fragmentação do seu território usado evidenciando suas características metropolitanas e a demanda crescente por serviços avançados. Brasília, a metrópole nacional tem procurado estabelecer sua matriz produtiva diferente da sua função administrativa para inserção na acumulação flexível. O crescimento do setor de serviços avançados aponta que estão presentes as técnicas em seu território usado para o seu desenvolvimento econômico. No entanto, ressalto que este processo não é mecânico e pode sofrer interferências. Existem outras dinâmicas envolvidas que podem trazer mudanças com relação ao planejado.

É justamente sobre estas interferências que vamos pensar no próximo capítulo em relação ao nosso objeto específico, o Parque Tecnológico Capital Digital. O projeto do PTCD foi pensado no início deste século (2002) mas a sua implantação começou em 2011, ou seja, uma década depois. Essa situação sugere que não apenas as condições econômicas, os recursos financeiros, a mão de obra qualificada e um mercado consumidor entre outros fatores de localização que mencionamos no Capítulo 3, seriam suficientes para a implementação do Parque Tecnológico Capital Digital.

Assim, podemos supor que as ações dos agentes envolvidos no PTCD também tem permitido avanços ou recuos em sua implementação. Vamos entender que estes agentes (Governo, estrutura produtiva e infraestrutura de ciência e tecnologia) apresentam visões diferentes sobre o PTCD e que suas articulações podem interferir na dinâmica de implantação do parque. Uma pesquisa exploratória com alguns destes agentes sugeriu que a sua fase de implantação apresenta nuances. O projeto do parque pensado numa perspectiva econômica com todos os condicionantes necessários a sua inserção na acumulação flexível não tem conseguido solucionar conflitos de interesses, pois existem outras referências ou perspectivas de diferentes atores como abordaremos a seguir. 


\section{Capítulo 6}

\section{O PARQUE TECNOLÓGICO CAPITAL DIGITAL DE BRASÍLIA}

"A tecnologia cria dinâmica própria que se mantém com toda a rebeldia em relação à realidade. Em vez de ajustar-se e substituir-se por outro modelo, a tecnologia prevalecente domina o sistema social e econômico: força uma elevação nos gastos com infraestrutura urbana, exige subsídios (...). Em vez de substituí-la por outra mais racional e adaptada à nova realidade, a sociedade se ajusta à realidade da tecnologia."

(BUARQUE, Cristovam R. O. A desordem do progresso: o fim da era dos economistas e a construção do futuro. Rio de Janeiro: Paz e Terra, 1990) 


\subsection{Contexto da Ciência e Tecnologia em Brasília}

Antes de tentar compreender as intencionalidades dos atores envolvidos no Parque Tecnológico Capital Digital vamos primeiro delinear o setor de inovações em Brasília como um cenário para a implementação do parque. Vamos verificar quais as políticas ou planos de Ciência e Tecnologia e as instituições ou agentes envolvidos neste processo. Assim, retomamos aqui a lógica do espaço-tempo, passado-presente-futuro na compreensão de nosso objeto de estudo.

As políticas de desenvolvimento tecnológico no Distrito Federal são recentes. Com apenas cinquenta e seis anos de existência, Brasília teve o seu primeiro plano de desenvolvimento elaborado no final da década de 1980, constituindo este o primeiro momento para o surgimento de uma nova funcionalidade.

O Plano Trienal 1986/1988, ou Plano de Desenvolvimento Econômico e Social do Distrito Federal (PDES - DF), tinha como meta o desenvolvimento da produção, comércio e consumo de bens e serviços, mais especificamente e entre outros, desenvolver o Programa Polo de Alta Tecnologia, compreendendo áreas de biotecnologia, informática e novos materiais (PDES, 1986).

O instrumento dessa política foi o Programa de Desenvolvimento Industrial do Distrito Federal (PROIN), instituído pelo Decreto no 11.568/89. O objetivo do programa era identificar as oportunidades que aumentariam o processo de expansão industrial para o alcance de resultados econômicos e sociais como o aumento da produção de bens e serviços, a geração de emprego e renda e a promoção do equilíbrio entre os setores primário, secundário e terciário.

Em 1986, por meio da Lei n. ${ }^{0} 7.456 / 86$, o Governo do Distrito Federal criou a Secretaria de Indústria, Comércio e Turismo (SIC/DF). A função dessa secretaria era planejar, executar, assessorar, promover e integrar a política de desenvolvimento de Brasília. A sua competência era estimular o desenvolvimento industrial, comercial e turístico; promover e auxiliar o cooperativismo na indústria e; promover assistência técnica e tecnológica às micro, pequenas e médias empresas.

O órgão responsável por operacionalizar o PROIN era o CDI-DF - Conselho de Desenvolvimento Industrial composto por representantes do governo e da iniciativa privada que compunham o CDI/DF. O objetivo do CDI era prestar o apoio técnico, no assessoramento de iniciativas relacionadas com o desenvolvimento industrial, relativas à implantação, ampliação e modernização das indústrias, concedendo-lhes incentivos. Em 
1992, a Lei $\mathrm{n}^{\circ} 289$ alterou o nome do PROIN para PRODECON/DF - Programa de Desenvolvimento Econômico do Distrito Federal.

$\mathrm{Na}$ tentativa de melhor distribuição das atividades produtivas, o Plano de Governo 1991/1994 definiu uma Política Industrial, que tinha como objetivo a dinamização do processo de industrialização do Distrito Federal em sintonia com as políticas de meio ambiente, com prioridade às pequenas e médias indústrias, às de alta tecnologia ou caracterizadas pela introdução de inovações.

Os objetivos a serem alcançados pela Política Industrial foram: a) gerar empregos para mão de obra qualificada e não qualificada; b) ampliar a autonomia de abastecimento do Distrito Federal e gerar excedentes exportáveis; c) reduzir a dependência orçamentária do Distrito Federal pelo aumento de arrecadação; d) agregar o maior valor possível à manipulação dos insumos locais; e) aprimorar a produtividade e qualidade das indústrias locais. Dentre as diretrizes específicas do plano destacavam-se: a) incentivo à transferência de tecnologia entre universidade, setores estatais e privados; b) incentivo à criação de polos industriais com empresas de desenvolvimento tecnológico ${ }^{72}$.

Entre as ações preconizadas para realização dessas diretrizes destacam-se: a) incentivo à criação de polos industriais, com ênfase na informática, gemologia, cultura e lazer, definindo as áreas de implantação, dando prioridade às de utilização intensiva de mão de obra local e que considerem as vocações da região; b) promoção de acordos entre o Governo do Distrito Federal, as universidades, os órgãos de pesquisas e os setores privados, com vista ao intercâmbio de tecnologia; c) a geração de incentivos fiscais; d) o apoio ao desenvolvimento tecnológico e gerencial por meio das ações estabelecidas nos planos de oportunidade de mercado e captação de investimentos; e) formação e aperfeiçoamento de recursos humanos, qualidade produtiva, competitividade industrial e de utilização de fontes de financiamentos e incentivos ${ }^{73}$.

Em 1994, o Decreto $\mathrm{n}^{\circ} 15.058$ reestabeleceu as competências básicas da Secretaria de Indústria e Comércio, que tinha como objetivo a promoção do desenvolvimento regional dos setores de indústria, comércio e serviços, compreendendo as ações de: a) planejamento e execução da política industrial, comercial e de serviços do Distrito Federal; b) apoio ao setor empresarial; c) promoção e estímulo ao

\footnotetext{
72 Primeiras diretrizes para a implantação do parque tecnológico.

${ }^{73}$ Esses planos não serão detalhados nesta Tese. Mas vale ressaltar que foram de grande importância para a consolidação da política de desenvolvimento industrial e tecnológico do Distrito Federal.
} 
desenvolvimento das atividades industriais, comerciais e de serviços; d) assistência técnica e tecnológica à produção industrial, às atividades comerciais e de serviços.

Em 1995, elaborou-se o Plano de Desenvolvimento Econômico do Distrito Federal (1996-1999), no qual foram estabelecidas as diretrizes gerais, os objetivos e as políticas globais e setoriais. O plano previa apoio aos setores econômicos, não só àqueles referentes ao desenvolvimento tecnológico e de turismo, mas também ao desenvolvimento agrícola e aos serviços.

O Plano de Desenvolvimento Econômico e Social do Distrito Federal (PDESDF) considerou setores estratégicos a serem incentivados para se viabilizar as condições necessárias para o desenvolvimento. Esses setores são associados aos projetos estruturantes para as definições das potencialidades para o desenvolvimento do Distrito Federal, conforme demonstrado compreendendo: a) industrialização de Alta Tecnologia; b) desenvolvimento turístico; c) produção de inteligência; c) industrialização tradicional e; e) desenvolvimento agrícola.

O desenvolvimento tecnológico no Distrito Federal vem sendo realizado pelo do Programa de Promoção do Desenvolvimento Econômico Integrado e Sustentável do Distrito Federal - Pró-DF ${ }^{74}$, instituído pela Lei $n^{\circ}$ 2.427/99. O seu objetivo é apoiar as iniciativas de negócios que produzam bens, serviços e difusões tecnológicas, gerem empregos e renda e promovam contribuição tributária para o Distrito Federal. As iniciativas empresariais quer sob a forma de implantação de novo empreendimento, quer sob a relocalização de empresas já existentes, desde que promovam investimentos capazes ou destinados a aumentar a produção de bens, serviços e inovações, melhorar a produtividade e a qualidade de produtos, podem beneficiar-se do programa Pró-DF.

O Pró-DF apoia o empresário em suas iniciativas, exigindo contrapartida, representada pela implantação do projeto no tempo certo contratado, produção de bens ou serviços, inovações e geração de empregos e renda. Caso os compromissos assumidos pelas empresas não sejam cumpridos, os benefícios são cancelados e o terreno retorna automaticamente ao programa.

Os incentivos são recebidos pelos empreendimentos que atendam aos objetivos do Pró-DF e às exigências da legislação. Os incentivos econômicos são: a) concessão de direito real de uso, com opção de compra do terreno destinado às instalações da empresa; b) concessão administrativa de uso, permissão ou autorização de uso, durante três anos, de

\footnotetext{
74 O programa encontra-se vigente e sofreu alterações em 2015 com o objetivo de garantir melhorias nos procedimentos de inserção no programa (SDE, 2016).
} 
módulos em galpões industriais, destinados a microempresas, preferencialmente assistidas e selecionadas pelo CDT/UnB.

Os projetos de empreendimentos econômicos deverão apresentar viabilidade técnica, econômica e financeira, e serem compatíveis com o zoneamento estabelecido pelo Plano Diretor de Ordenamento Territorial do Distrito Federal - PDOT (2009) e com o Plano Diretor Local - PDL da respectiva Região Administrativa - RA.

Houve ainda a promulgação da Agenda de Ciência e Tecnologia do Distrito Federal por meio do decreto $n^{\circ}$ 25.752/05, resultado de uma articulação entre o Governo Federal, iniciativa privada, instituições de ensino e pesquisa e agências de desenvolvimento no Distrito Federal executando-se as seguintes ações: a implantação do Parque Tecnológico Capital Digital - PTCD; o apoio à organização dos diversos arranjos produtivos do Distrito Federal, como Tecnologia da Informação e Comunicação - TIC, agricultura orgânica, móveis, moda e confecções.

A responsabilidade pelo desenvolvimento de Ciência e Tecnologia no Distrito Federal é competência da Secretaria de Estado de Economia e Desenvolvimento Sustentável - SEDS. A infraestrutura de Ciência e Tecnologia no Distrito Federal é composta pela Fundação de Apoio à Pesquisa - FAP/DF.

O apoio ao desenvolvimento científico e tecnológico no Distrito Federal é de competência da Fundação de Apoio à Pesquisa - FAP/DF, instituída pela Lei $n^{\circ} 347$ de 1992. A FAP/DF incorporou o Instituto de Ciência e Tecnologia - ICT/DF através do Decreto $n^{\circ} 21.452 / 2000$, tornando-se o único órgão responsável pelo apoio e execução de projetos que envolvam ciência e tecnologia no Distrito Federal. Seu objetivo é estimular, apoiar e promover o desenvolvimento científico- tecnológico do Distrito Federal, realizando as seguintes ações: a) fomento à pesquisa científica e tecnológica; b) capacitação, modernização e recuperação da capacidade laboratorial do Distrito Federal; c) apoio à realização e participação de eventos; e) difusão científico-tecnológico. Para a realização dessas ações, a FAP/DF dispõe das seguintes modalidades de apoio: 1) projetos de pesquisa; 2) organização de eventos; 3) capacitação de laboratórios e 4) pesquisador visitante.

Compõe a estrutura da FAP/DF, o Conselho de Ciência e Tecnologia do Distrito Federal - CCT/DF, criado pela Lei n 805 de 1994 e tem como competência formular, acompanhar e avaliar o plano de C\&T do Distrito Federal. Possui composição paritária e é integrado por representantes de entidades da sociedade civil e de órgãos 
governamentais envolvidos com a geração e aplicação do conhecimento científico e tecnológico e com as consequências e impactos dela resultante.

As seguintes competências foram incorporadas à FAP/DF: a) executar a Política de Desenvolvimento Científico e Tecnológico do Distrito Federal; b) realizar planos, programas, projetos e atividades de fomento ao desenvolvimento científico e tecnológico; c) cooperar na formalização e execução da Política Nacional de Desenvolvimento Científico e Tecnológico; d) difundir informações e conhecimentos científicos e tecnológicos; e) estimular a difusão e transferência de tecnologia às atividades econômicas públicas e privadas; f) estimular a integração das atividades de produção, serviços, pesquisa, extensão e ensino; g) gerar o Fundo de Apoio à Pesquisa do Distrito Federal, instituído pela Lei Complementar n 153 de 1998.

Compete ainda à FAP/DF estimular a modernização empresarial por meio de ações nas áreas de qualidade, produtividade e capacitação tecnológica, estimular a criação de empresas de base tecnológica e promover a capacitação de recursos humanos nas áreas de interesse do desenvolvimento científico e tecnológico.

Dentre os programas desenvolvidos pela FAP/DF destacam-se: o Programa de Tecnologias Apropriadas; o Núcleo de Pesquisa, Capacitação e Produção de Papel Artesanal; o Programa de Resíduos; o Programa de Atendimento ao Inventor; o Programa de Levantamento e acompanhamento dos Sistemas Estaduais de Ciência e Tecnologia PROSECT; o Projeto Censo Tecnológico - CENSOTEC; o Projeto Faça o seu papel e o Projeto de eficiência energética do Distrito Federal.

O Programa de Tecnologias Apropriadas - PTA/DF considera a tecnologia como importante instrumento de transformação de uma situação pelo emprego de técnicas de aprimoramento já desenvolvidas e de fácil adaptação, direcionadas ao aproveitamento das potencialidades de Brasília. Os núcleos de desenvolvimento empresarial do Distrito Federal recebem especial atenção da SEDS, pois considera esses núcleos setoriais fundamentais para o desenvolvimento econômico. Têm como meta atender às necessidades de modernização tecnológica e gerencial dos setores produtivos do Distrito Federal, atuando em parceria com os empresários setoriais e outros órgãos de fomento, assessoria e formação de recursos humanos.

O Programa de Atendimento ao Inventor está sendo realizado para o assessoramento ao inventor do Distrito Federal e Entorno, procurando realizar o cadastramento do invento junto ao INPI até a produção, na medida do possível, de 
protótipos e testes de viabilidade econômica. As parcerias foram estabelecidas com SEBRAE/DF, INPI, SENAI/DF, CNPq.

O Projeto Censo Tecnológico - CENSOTEC procura identificar a oferta de serviços tecnológicos junto a instituições de pesquisa do Distrito Federal, a demanda por tais serviços e a disponibilidade para população. As parcerias foram estabelecidas entre o CDT/UnB, SENAI/DF, IEL/FIBRA. O Projeto de eficiência energética do Distrito Federal busca a realização de estudos, atividades de conscientização das entidades públicas e privadas para o uso racional dos recursos energéticos disponíveis. As parcerias foram estabelecidas com a ELETROBRÁS, CEB, SEBRAE, SENAI/DF, FURNAS e CNPq.

Na Figura 6.1 estão presentes os órgãos e os agentes envolvidos que compõem a infraestrutura de Ciência e Tecnologia no Distrito Federal. O detalhamento dos agentes envolvidos no processo de desenvolvimento tecnológico estão elencados no Quadro 6.1.

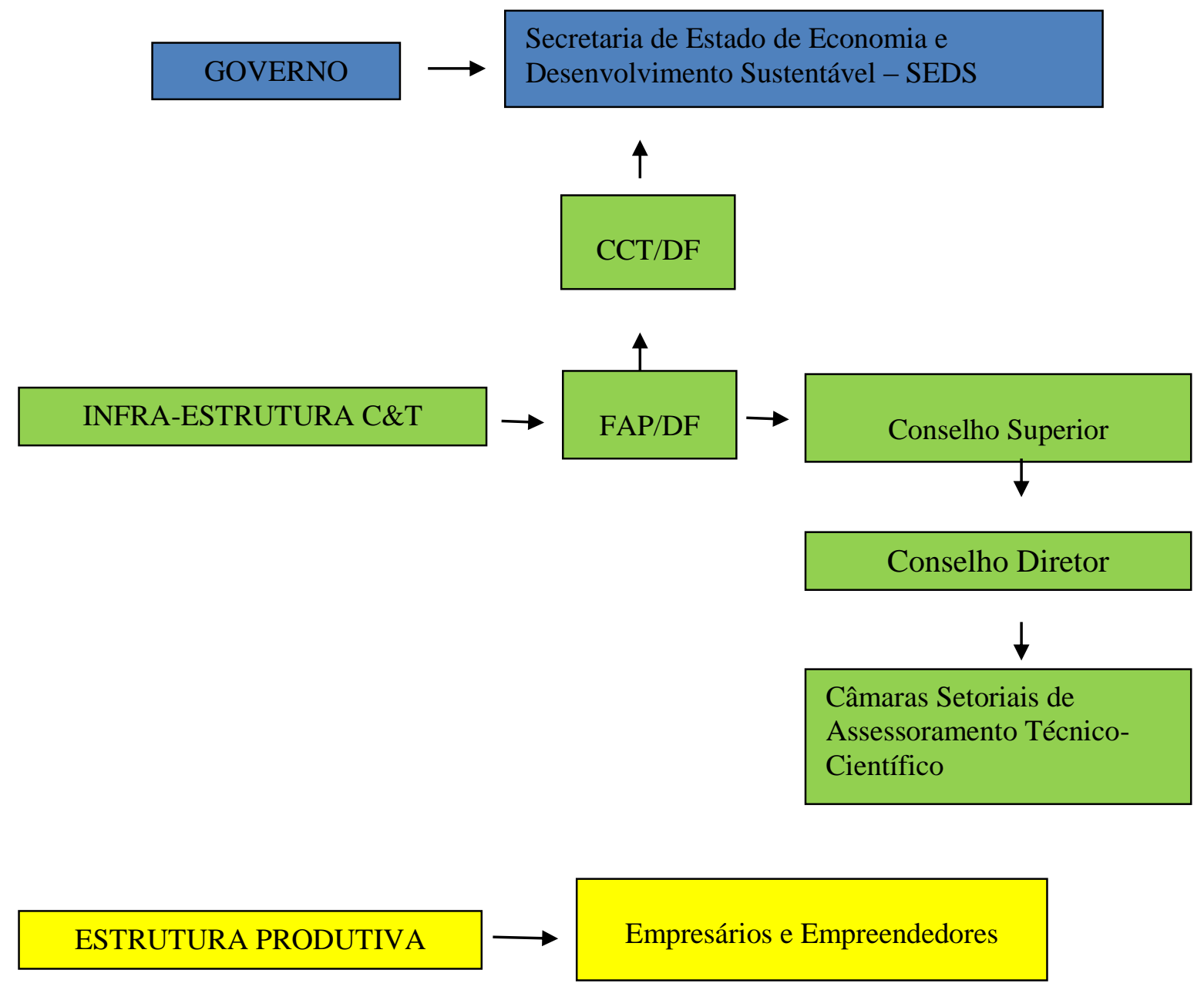

Figura 6.1 Agentes de C\&T no Distrito Federal

Mostra os órgãos e os agentes envolvidos que compõem a infraestrutura de C\&T no DF.

Fonte: Elaborada pelo autor. 
O Quadro 6.1 traz o detalhamento dos agentes componentes da infraestrutura de Ciência e Tecnologia no Distrito Federal. O CCT/DF é composto por representante dos empresários dos setores industrial e comercial, representante de associações de trabalhadores, representantes de instituições de pesquisa do Distrito Federal e representante da Universidade de Brasília.

\section{Quadro 6.1 Detalhamento dos agentes componentes da} infraestrutura de C\&T no Distrito Federal

\begin{tabular}{|c|c|c|c|}
\hline ÓRGÃO & ESTRUTURA & & COMPONENTES \\
\hline \multirow{3}{*}{ FAP/DF } & Conselho Superior & \multicolumn{2}{|c|}{$\begin{array}{l}\text { Presidente FAP/DF } \\
6 \text { membros indicados pelo GDF } \\
6 \text { membros representantes da sociedade civil e } \\
\text { científico-tecnológica }\end{array}$} \\
\hline & Conselho Diretor & \multicolumn{2}{|c|}{ Diretores administrativos e técnico-científicos } \\
\hline & $\begin{array}{l}\text { Câmaras Setoriais de } \\
\text { Assessoramento }\end{array}$ & \multicolumn{2}{|l|}{ Especialistas } \\
\hline & \multirow[b]{3}{*}{$\mathrm{CCT} / \mathrm{DF}$} & \multirow[b]{2}{*}{$\begin{array}{l}\text { Membros } \\
\text { Natos }\end{array}$} & Secretário da SEDS \\
\hline & & & $\begin{array}{l}\text { Presidente FAP/DF } \\
\text { Secretários de Governo } \\
\text { Secretário de Governo (Casa Civil) } \\
\text { Procurador-Geral do DF }\end{array}$ \\
\hline & & $\begin{array}{l}\text { Membros } \\
\text { Nomeados } \\
\text { pelo } \\
\text { Governador } \\
\text { do DF }\end{array}$ & $\begin{array}{l}1 \text { representante de associações patronais } \\
\text { dos setores industrial e comercial } \\
1 \text { representante de } \\
\text { associações de trabalhadores } \\
2 \text { representantes de instituições de } \\
\text { pesquisa sediadas no DF } \\
1 \text { representante das universidades } \\
\text { públicas sediadas no DF }\end{array}$ \\
\hline
\end{tabular}

Fonte: Elaborado pelo autor

O setor de informática é considerado um setor estratégico no desenvolvimento tecnológico do Distrito Federal, pois dispõe das seguintes condições: a) apresenta demanda permanente representada pelos setores público e bancário; b) possui diversas empresas de inovação ${ }^{75}$ que conferem a Brasília posição de destaque no cenário nacional; c) possui empresas modernas e empreendedoras, que empregam tecnologias competitivas e possuem elevada capacidade gerencial; d) apresenta uma rede de instituições de ensino superior e de nível médio de formação de mão de obra; e) realiza parcerias constantes com o GDF.

\footnotetext{
75 Existem no Distrito Federal cerca de 700 empresas de inovação segundo SINFOR (2016).
} 
Por estas condições, Cidade (2014, p. 172) afirma que o setor terciário ainda é predominante na capital, devido a concentração dos postos de trabalho no funcionalismo público, mas existe uma tendência a demanda por serviços mais especializados, mais informatizados para atender um mercado consumidor significativo e exigente, gerando novos setores produtivos na área de informática.

Além dessas características, o setor de informática do Distrito Federal possibilita atividades irradiadoras de tecnologias geradoras de novas atividades econômicas, pelo efeito multiplicador dos investimentos, capazes de criar novas empresas permitindo ainda que outras empresas evoluam tecnologicamente com a introdução de softwares, os quais elevam a produtividade e melhoram a qualidade dos produtos e serviços.

O setor de informática de Brasília é composto por microempresas ${ }^{76}$ médias e pequenas. Dados da CODEPLAN do ano de 2010 informam que as microempresas representavam cerca de $87 \%$ do setor. A personalidade jurídica era composta por empresas matrizes $(83 \%)$, as de sociedade limitada $(85 \%)$ e as filiais $16,77 \%$. As atividades desenvolvidas por essas empresas são na área de hardware e software.

As atividades dessas microempresas são desenvolvidas na seguinte proporção: $71 \%$ produzem na área de hardware e $29 \%$ na área de software. Nessas duas áreas, a principal atividade é a prestação de serviços técnicos de informática. As empresas de software exercem, como segunda atividade, a produção de programas de computador para usos diversos, o processamento de dados e a automação de escritórios. As empresas de hardware exercem também a teleinformática (21\%) e a automação de escritórios (16\%).

O setor de prestação de serviços exercidos por essas empresas é bastante diversificado, e atuam nas seguintes áreas: treinamento, assessoria e consultoria, manutenção de hardware, digitação e processamento de dados, e empresas que mantém bancos de dados de grande porte e especializados. Além dessas áreas de atuação, o setor de informática desenvolve: produtos e sistemas; controle de processo industrial; sistemas de atendimento ao usuário; painéis eletrônicos; comunicação de dados; microcomputadores comerciais e industriais; circuito impresso; estações remotas de aquisição de sinais; sistemas aplicativos administrativos; telemarketing; equipamentos de telecomunicações; fontes de alimentação e sistemas de automação bancária. O Quadro 6.2 faz referência às

\footnotetext{
${ }^{76}$ Microempresas são aquelas que possuem menos de vinte e nove empregados.
} 
empresas de grande porte que compram os produtos (hardwares e softwares) desenvolvidos pelo setor de informática do Distrito Federal.

Quadro 6.2 Grandes empresas compradoras de tecnologia em Brasília

\begin{tabular}{c|l}
\hline PÚBLICAS/ & $\begin{array}{l}\text { ELETRONORTE, FURNAS, CEB, INSS, } \\
\text { CORREIOS E TELÉGRAFOS, CAESB, } \\
\text { PETROBRÁS, CINDACTA, METRÔ-SP, } \\
\text { SABESP }\end{array}$ \\
\hline PRIVADAS & $\begin{array}{l}\text { Mitutoyo do Brasil, NEC do Brasil, MAXION, } \\
\text { BOSCH, FORD, IBM BRASIL, USIMINAS, } \\
\text { Shopping centers entre outros. }\end{array}$ \\
\hline OUTROS & Universidades federais e estaduais \\
\hline
\end{tabular}

Fonte: Elaborado pelo autor.

Pensando neste mercado promissor, o Governo do Distrito Federal para fazer frente às novas demandas por serviços tecnológicos, elaborou o Plano Diretor de Tecnologia da Informação - PDTI (Nov-2015) que estabelece as políticas, planos, diretrizes, ações e metas para os assuntos correlatos à Tecnologia da Informação, atendendo às premissas do anexo único do Decreto no 33.528 de 10 de fevereiro de 2012 , que dispõe sobre a aprovação de Estratégia Geral de Tecnologia de Informação - EGTI. O plano tem por objetivo planejar, supervisionar e avaliar as ações e programas de modernização tecnológica. Contempla o plano a missão da SEDS que é promover o desenvolvimento econômico e executar políticas de fomento à atividade produtiva do Distrito Federal e região metropolitana, com foco na atração de investimentos.

A primeira tentativa de estabelecer uma área para empresas de Ciência e Tecnologia no Distrito Federal foi em 1991, com a delimitação de área para um polo de alta tecnologia no SAAN - Setor de Armazenagem e Abastecimento Norte. Porém a área deixou de ser escolhida pelo fato de ser destinada a outros setores econômica o que descaracterizaria a vocação específica do polo. Assim, no ano de 1992, destinou-se uma nova área no Núcleo Bandeirante denominada SIBS - Setor Industrial Bernardo Sayão. O Governo local criou incentivos (fiscais e financiamentos dos lotes) para a instalação de empresas de tecnologia da informação e comunicação neste polo. Dentre as empresas que se encontram em funcionamento no SIBS podemos citar, CALL, CDS, Sitran, Softway, Maxtera, Novadata, Proineg, Rhox, STD, Telemikro, Transoft e WISE, algumas destas provenientes da incubadora de empresas do CDT/UnB. 
No entanto, mesmo diante do sucesso da iniciativa no início dos anos 1990 a destinação produtiva do SIBS sofreu modificações permitindo a instalação de outros setores econômicos descaracterizando a destinação específica do polo. As Figuras 6.2 e 6.3 mostram outras atividades econômicas no polo SIBS que desvirtuaram a finalidade prevista que era de tecnologia da informação e comunicação.
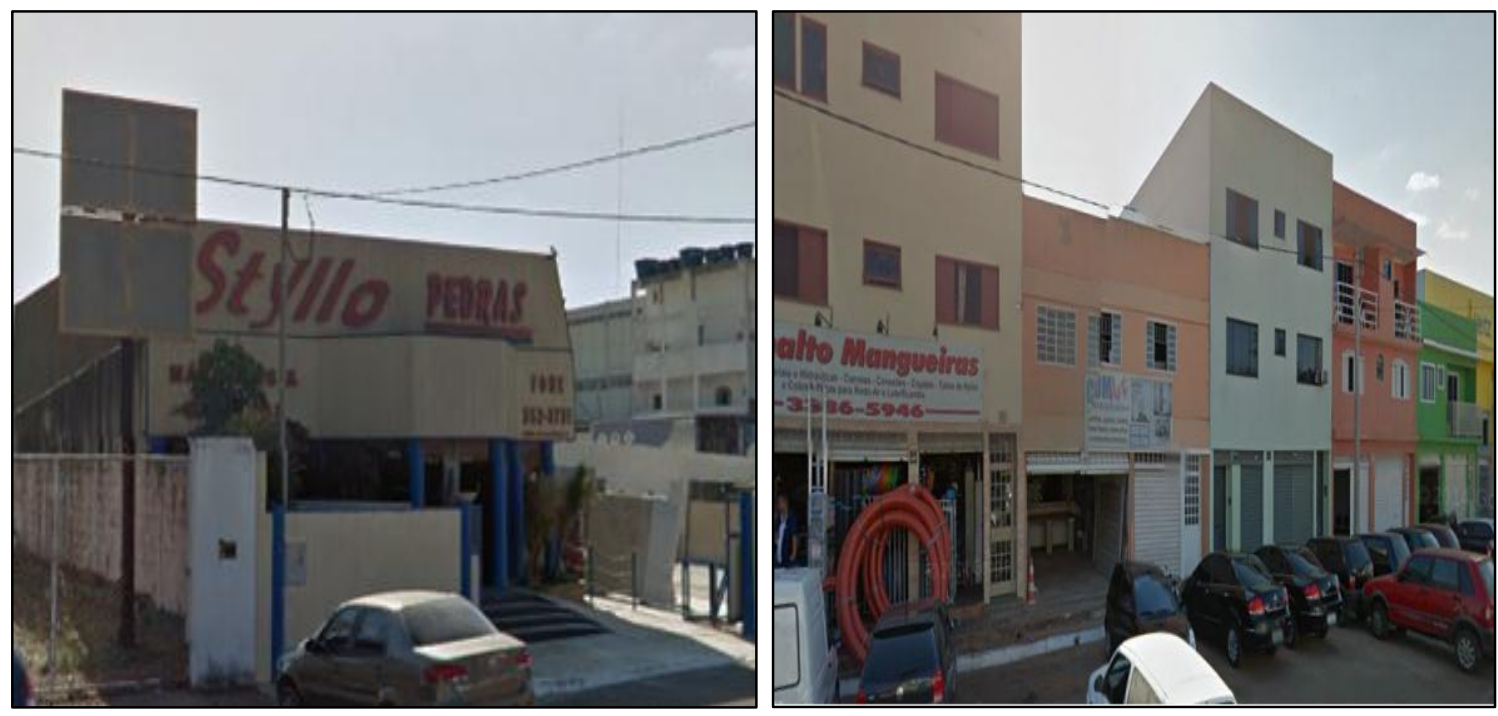

Figuras 6.2 e 6.3 Outras atividades econômicas no SIBS

As figuras mostram outras atividades econômicas no SIBS como comércio de pedras e materiais elétricos e hidráulicos. Mostram ainda o padrão irregular das edificações. Nos parques tecnológicos as edificações são realizadas a partir de projetos arquitetônicos elaborados.

Fonte: Arquivo do autor

Mesmo diante dos problemas enfrentados o SIBS é considerado um marco inicial no setor de inovações no Distrito Federal, pois foram realizados investimentos na área como a instalação da infraestrutura e a concessão de incentivos fiscais e creditícios do Programa de Desenvolvimento Industrial do Distrito Federal (PROIN). Brasília, nesse contexto, pode ser encarada, com base nas considerações de Harvey (1992), como "um grande negócio", resultante de um novo empreendedorismo urbano com estilo de governance, no qual o Estado apareceu como o facilitador. Dessa forma, o programa de desenvolvimento tecnológico na capital tem como objetivo principal viabilizar o desenvolvimento econômico a partir da definição e da elaboração de projetos de parcelamento urbano, disponibilizando-as para a implantação de empresas de inovação nos seguintes locais: a) Centro de Apoio ao Desenvolvimento Tecnológico da Universidade de Brasília (CDT/UnB); b) o Parque Tecnológico Capital Digital. Essas áreas são destinadas a empresas com expressivo componente de insumos de conhecimento científico e tecnológico. 


\subsection{Trajetória do CDT/UnB como difusor de inovação em Brasília}

De acordo com Medeiros et al (1992, p.66) o Centro de Apoio ao Desenvolvimento Tecnológico da Universidade de Brasília (CDT/UnB), surgiu em 1986 para ser um instrumento da UnB na integração universidade-empresa e tem como objetivo coordenar ações que possibilitem gerar novos empreendimentos e aumentar o vínculo das empresas já existentes com os departamentos e núcleos da UnB.

A missão estratégica do CDT/UnB é promover e apoiar o desenvolvimento tecnológico, com base nas características da região, fortalecendo o crescimento econômico e social. O Centro de Apoio ao Desenvolvimento Tecnológico da Universidade de Brasília (CDT/UnB), além dos vínculos que mantém com o setor produtivo, busca também o respaldo do Governo do Distrito Federal e das agências federais. A sua equipe é composta pelo diretor, administradores, secretários, auxiliares administrativos e engenheiros (MEDEIROS et al, 1992, p.67).

Dentre as atividades realizadas pelo Centro de Apoio ao Desenvolvimento Tecnológico da Universidade de Brasília (CDT/UnB), destaca-se além do gerenciamento às incubadoras, a responsabilidade de elaboração do parque tecnológico e o levantamento das potencialidades existentes na UnB e outras instituições. O CDT/UnB promove, ainda, a transferência de tecnologia para o setor produtivo e assessora os pesquisadores-professores em suas relações com as empresas, encarregando-se também pela identificação de linhas de financiamento que facilitem o desenvolvimento tecnológico. Exemplo disso é a presença da AUTOTRAC, empresa em funcionamento no parque tecnológico.

O CDT/UnB recebe apoio financeiro e institucional da Federação das Indústrias do Distrito Federal - FIBRA-DF, da Secretaria de Estado de Economia e Desenvolvimento Sustentável - SEDS, do Serviço de Apoio às Micro e Pequenas Empresas do DF - SEBRAE/DF) e do Programa de Recursos Humanos em Áreas Estratégicas RHAE.

O Centro de Apoio ao Desenvolvimento Tecnológico da Universidade de Brasília encontra-se no campus da UnB e possui uma incubadora ${ }^{77}$, o que lhe confere uma condição privilegiada por estar presente dentro das instalações de uma universidade. Essa situação lhe é apropriada porque explora as vantagens decorrentes da proximidade física

77 Os parques tecnológicos podem abrigar incubadoras de empresas, que são instalações físicas subdivididas em módulos, utilizadas por empresários que estão formando novas empresas. 
entre as empresas da incubadora e a infraestrutura de recursos humanos e materiais existentes na universidade ${ }^{78}$.

O Centro de Apoio ao Desenvolvimento Tecnológico da Universidade de Brasília compreende o resultado das ações conjuntas entre a iniciativa privada, o governo e a universidade. O Centro de Apoio ao Desenvolvimento Tecnológico - CDT/UnB está localizado entre a Via L2 Norte e o Setor de Clubes Norte, possuindo facilidade de acesso para a comunidade acadêmica. $\mathrm{O}$ centro de pesquisa e desenvolvimento foi concebido para desenvolver diversas atividades ligadas a produtos e serviços inovadores ou de máxima qualidade. A Figura 6.4 mostra imagem aérea da estrutura física do parque tecnológico que possui o prédio do CDT/UnB e da AUTOTRAC - empresa de base tecnológica que se encontra em funcionamento.

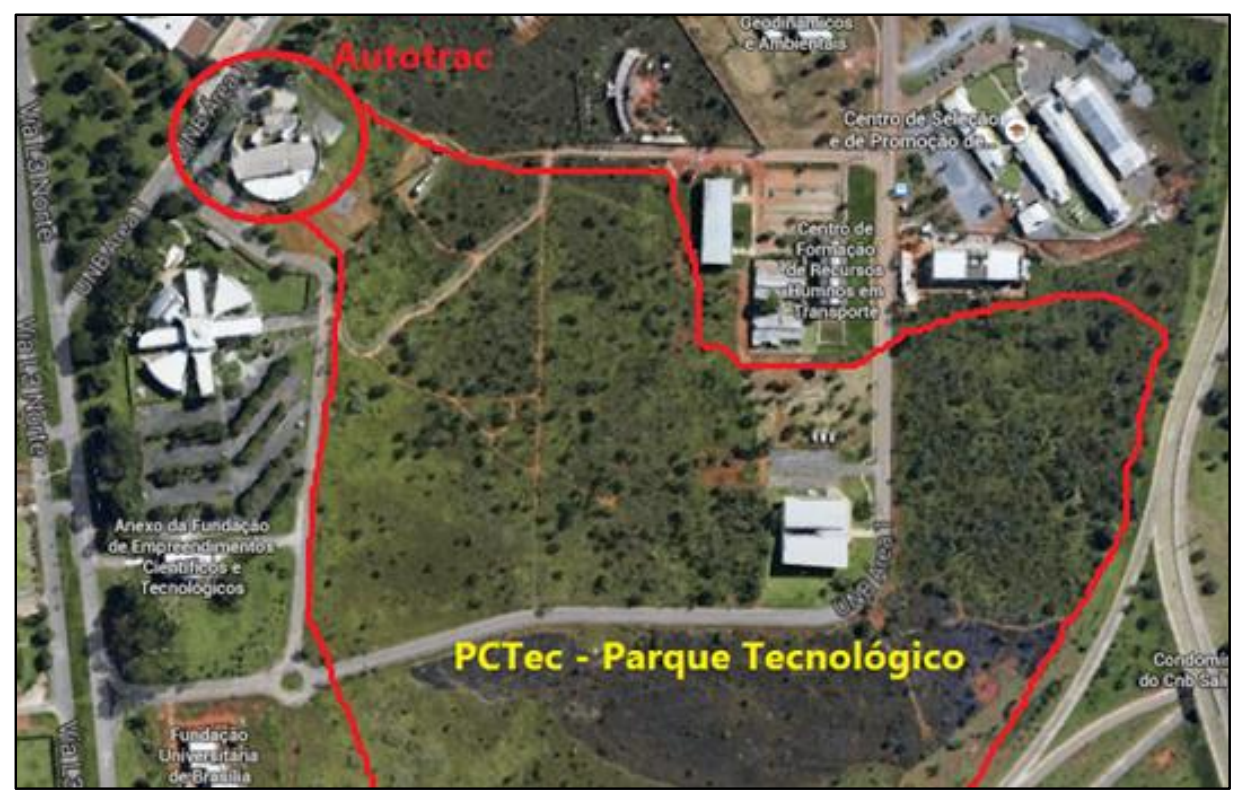

Figura 6.4 Localização do CDT/UnB

Mostra a área destinada ao parque tecnológico e a localização da empresa de base tecnológica no parqueAUTOTRAC (assinalada em um círculo vermelho). A figura mostra ainda a proximidade de outros centros acadêmicos e de pesquisa da Universidade de Brasilia e as vias de acesso ao parque. Fonte: CDT/UnB

${ }^{78}$ As incubadoras podem também receber projetos patrocinados por empresas já existentes e não necessitam necessariamente estarem inseridas num parque tecnológico. As empresas ou projetos permanecem na incubadora por prazo determinado. 
A incubadora abriga diversas empresas que atuam na área de mecânica de precisão, biotecnologia e informática ${ }^{79}$. As empresas que estão instaladas na incubadora, entre outras, são: Allians Technologies, Hexen Tecnologia, Integra Bioprocessos e Análises, Inv Tecnologia, Loop Engenharia de Computação, Acofren Tecnologias Químicas, Orakolo Tecnologia, Radd's, Terrasense e Vivat TI Educacional.

Os equipamentos produzidos por estas empresas destinam-se à monitoração meteorológica e controle remoto, controle e automação de processos, instrumentação automática e processamento digital de sinais para múltiplas aplicações. Entre os resultados obtidos na área de software, destacam-se: eletrocardiógrafo computadorizado para a área biomédica; automação de laboratórios e escritórios; sistema de aquisição, geração e análise de sinais; e software de controle de placas wi-fi para computadores pessoais.

As empresas na incubadora privilegiam, ainda, o setor de serviços. As atividades se concentram no teleprocessamento, redes locais de computadores, manutenção de computadores e periféricos, proteção e controle digitalizado para sistemas elétricos de potência e industriais e o treinamento especializado em informática e microeletrônica.

O Quadro 6.3 traz as principais atividades desenvolvidas por estas empresas na incubadora. Os incentivos oferecidos pelo CDT/UnB são: a infraestrutura que constitui o espaço físico destinado ao desenvolvimento das atividades, serviços administrativos, treinamento, laboratórios, consultorias especializadas e o marketing institucional.

Quadro 6.3 Atividades desenvolvidas pelas empresas na incubadora CDT/UnB

\begin{tabular}{c|l}
\hline Área de produção & Atividades desenvolvidas \\
\hline Informática & $\Rightarrow$ Software instrucional \\
& $\Rightarrow$ Software multimídia \\
& $\Rightarrow$ Catálogo multimídia especializado \\
& $\Rightarrow$ Equipamento de teste de modems \\
& $\Rightarrow$ Software e equipamentos de controle e \\
& $\Rightarrow$ Softwatomação aplicativos \\
\hline Mecânica de Precisão & $\Rightarrow$ Equipamentos de irrigação \\
& $\Rightarrow$ Software de controle \\
\hline Biotecnologia & $\Rightarrow$ Cultivo de espécies in vitro, isentas de pragas \\
\hline
\end{tabular}

Fonte: Elaborado pelo autor.

79 Este último setor destaca-se devido à demanda do centro administrativo de Brasília. 
Algumas empresas que estiveram na incubadora, estão graduadas e em funcionamento: Copertec Engenharia, Halta Tecnologia, Signaux Informática e Processo Digital de Sinais, Tecnolab Tecnologia Eletrônica, Werk Tecnologia, 3IN Instrumentação Integrada Informática, Aeronet, Badiu, Bluestar, Celler, Faro Brasil, Fira Soft, Geosonar, INBD Embedded Intelligence, IPe Engenharia de Redes, Kryos Tecnologia, Mais E-duc, MUX, Nanodynamics, Optmedia, Spin Engenharia de Automação Ltda, Tecnogene Diagnósticos Moleculares, Quali-a Consultoria Ambiental e, Z Tecnologia.

O CDT/UnB tem desenvolvido várias atividades ligadas à área tecnológica, por meio de programas, principalmente os voltados para a formação empreendedora destacando-se o Programa Empresa Júnior, o Programa Escola de Empreendedores e o Programa Jovem Empreendedor.

O Programa Empresa Júnior objetiva proporcionar ao estudante aplicações práticas de conhecimentos teóricos através de consultorias prestadas em sua área de formação e com a orientação de um professor, desenvolvendo o aspecto analítico e empreendedor no aluno e intensificando o relacionamento universidade-empresa. Os estudantes participantes do programa têm, além do contato com seu mercado de trabalho futuro, noções de gestão empresarial e administrativa e prática de comportamento empreendedor (CDT/UnB, 2015).

No Programa Escola de Empreendedores, com o apoio do SEBRAE-DF, o CDT/UnB tem fornecido cursos de formação empresarial para os alunos da área de tecnologia. O Programa Jovem Empreendedor é uma iniciativa que visa o estímulo e a difusão da cultura empreendedora e a criação de empresas de base tecnológica no âmbito das instituições de ensino superior, motivando o estudante universitário a ser um empreendedor e criar sua própria empresa. Esse programa tem como objetivos principais: a) propiciar aos estudantes de graduação e recém-formados, condições de desenvolver produtos e serviços que possam originar empresas de base tecnológica; b) propiciar aos professores e pesquisadores das instituições de $C \& T$ condições para transformar as suas pesquisas em produtos; c) difundir, junto ao corpo discente, a ideia da formação de pequenas empresas de base tecnológica (CDT/UnB, 2015). 


\subsection{Da concepção à concretização do PTCD no território usado de Brasília}

O Parque Tecnológico Capital Digital - PTCD foi idealizado no início do século XXI no contexto apresentado no Capítulo 5 desta Tese. O Distrito Federal neste período buscava acompanhar o dinamismo econômico verificado no país. Pensando na criação de uma matriz produtiva que diminuísse a dependência do setor público, o Governo do Distrito Federal ${ }^{80}$ elaborou o projeto do parque tecnológico no ano de 2002 sob a ótica do planejamento $^{81}$. Todavia, alguns entraves de natureza jurídica, política e ambiental ${ }^{82}$ impediram o seu avanço.

O Parque Tecnológico Capital Digital deveria está sendo implementado com a participação de todos os atores sociais envolvidos, pois se constitui numa tentativa de conciliar a área patrimonializada com a área metropolitana da cidade, vez que atribui "usos" ao território. Então, quem são estes atores? Qual a participação destes atores neste processo? Quais as suas visões sobre o parque tecnológico? Quais as suas expectativas?

Antes de tentar elucidar estes questionamentos, tenho aqui a tarefa de apresentar as características do Parque Tecnológico Capital Digital sob a ótica do planejamento e as suas interferências no território usado. Considero como premissa que o planejamento pensado para o parque por um dos agentes envolvidos (Governo) é uma técnica criada para exercer o poder de uso do território.

Retomo a afirmação de Raffestin (1993) exposta no Capítulo 2 de que o território é resultante das práticas de poder dos agentes e que o seu uso reflete essas relações de poder. Nesse sentido corrobora Milton Santos (1979) afirmando que o território usado se torna impregnado das formas-conteúdo ${ }^{83}$ que reproduzem as lógicas desiguais de acumulação de recursos para usos presentes e futuros do território ${ }^{84}$. Assim, o planejamento territorial executado pelo Estado é para Santos (1979) um instrumento (técnica) de implementação dessas formas-conteúdo que possibilita, ligadas a uma

\footnotetext{
80 Projeto elaborado pela secretaria de Estado na época denominada Secretaria de Desenvolvimento Econômico, Turismo, Ciência e Tecnologia (SDETCT), atual Secretaria de Estado de Economia, Desenvolvimento Sustentável e Turismo (SEDEST).

${ }^{81}$ Para Ab'Saber (1969, p.12), planejar é delimitar as diretrizes para corrigir os espaços mal organizados e improdutivos.

82 Os de natureza política diretamente ligados as ações dos agentes envolvidos serão discutidos a seguir, bem como as intervenções ambientais de sua implementação no território usado.

${ }^{83} \mathrm{O}$ objeto (forma) torna-se forma-conteúdo quando associado a uma totalidade social que age como uma força de transformação (Santos, 1979, p. 201).

${ }^{84} \mathrm{Ver}$ discussão sobre eventos no Capítulo 02.
} 
racionalidade, a reprodução do regime de acumulação capitalista, a competitividade e as desigualdades socioespaciais.

As considerações sobre os planos diretores para o Distrito Federal no Capítulo 5 demonstram as tentativas governamentais de construção de um ordenamento territorial e ao mesmo tempo, o desenvolvimento econômico com base no planejamento. Dentre estes planos destaco o PDOT/ 2012 que previu a criação de polos multifuncionais com a finalidade de reduzir a desigualdade territorial e a polarização do centro metropolitano de Brasília. Cidade (2001) aponta a importância do planejamento como indutor do desenvolvimento no território usado.

De acordo com Cidade (1998, p.45), o planejamento é um instrumento de tomada de decisão que possibilita a seleção dos meios alternativos disponíveis, que permitam atingir os objetivos da forma mais racional. Na mesma linha, complementando essas definições Ceron; Gerardi (1981, p. 108) afirmam ser o planejamento o conjunto de conhecimentos e de práticas destinadas a orientar e permitir a tomada de decisões para melhor mobilizar ou distribuir os recursos disponíveis. Para Rovati (2013) o planejamento deve ser elaborado de maneira interdisciplinar, contemplando a tomada de decisões quanto à elaboração de planos, programas e projetos.

De acordo com Becker (1991), o planejamento é um instrumento de gestão territorial de natureza técnica e centralizadora de intervenção estatal para ordenar o território de acordo com a política estabelecida. É justamente sob essa ótica que foi elaborado e está sendo implementado o Parque Tecnológico Capital Digital. Vejamos as suas principais características.

O Parque Tecnológico Capital Digital de Brasília (PTCD) foi criado pela Lei Complementar $n^{\circ}$ 679/2002, em área de 121,54 hectares na Zona Urbana de Uso Controlado II - RA-I - Plano Piloto. A Figura 6.5 indica o macrozoneamento do Distrito Federal e a macrozona urbana estabelecida no PDOT/2012 e em atendimento ao disposto a Portaria $n^{\circ}$ 68/2012 - IPHAN ${ }^{85}$. O parque está situado em área de formato triangular delimitado pela Granja do Torto, o Parque Nacional de Brasília e às margens da rodovia Epia Norte (DF-003).

\footnotetext{
${ }^{85}$ A portaria dispõe sobre a delimitação e diretrizes para a área de entorno do Conjunto Urbanístico de Brasília, sede da Capital da República Federativa do Brasil, situado no Distrito Federal, bem como objeto de tombamento federal pelo Instituto do Patrimônio Histórico e Artístico Nacional - IPHAN.
}

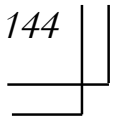


Figura 6.5 Macrozoneamento do Distrito Federal

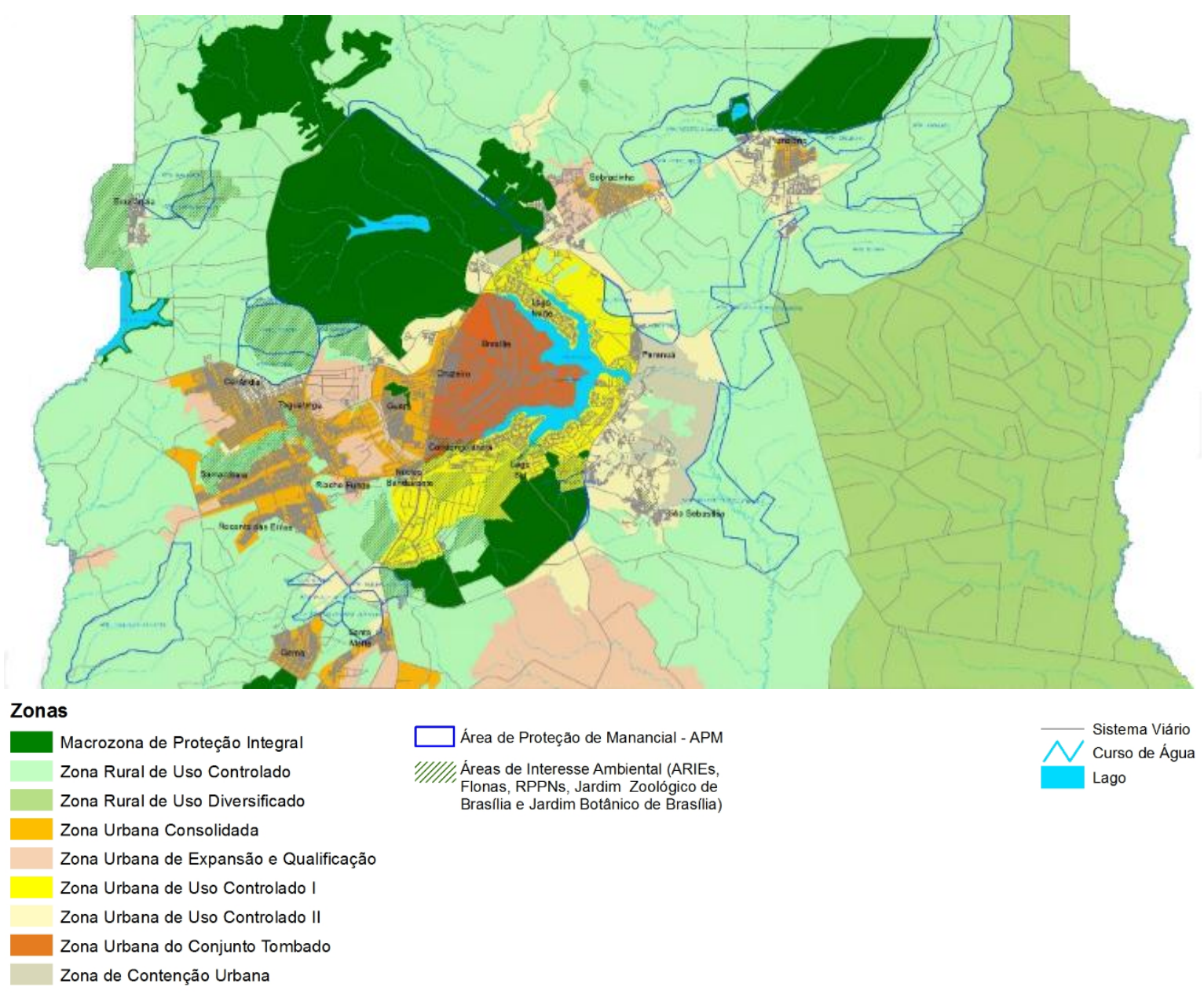

Fonte: PDOT, 2012.

A área do parque pertencia a União sendo necessária a sua doação ao GDF e ainda a definição da poligonal do Parque Nacional. Após inúmeros entraves jurídicos, em março de 2006, por meio da Lei $n^{\circ}$ 11.285/2006 foram fixados os limites do Parque Nacional de Brasília e a sua dimensão de 41 mil hectares. Essa delimitação foi o marco inicial para a implementação do parque tecnológico que teve sua área delimitada em formato triangular. A Figura 6.6 mostra o formato da área e a sua localização no Distrito Federal. 

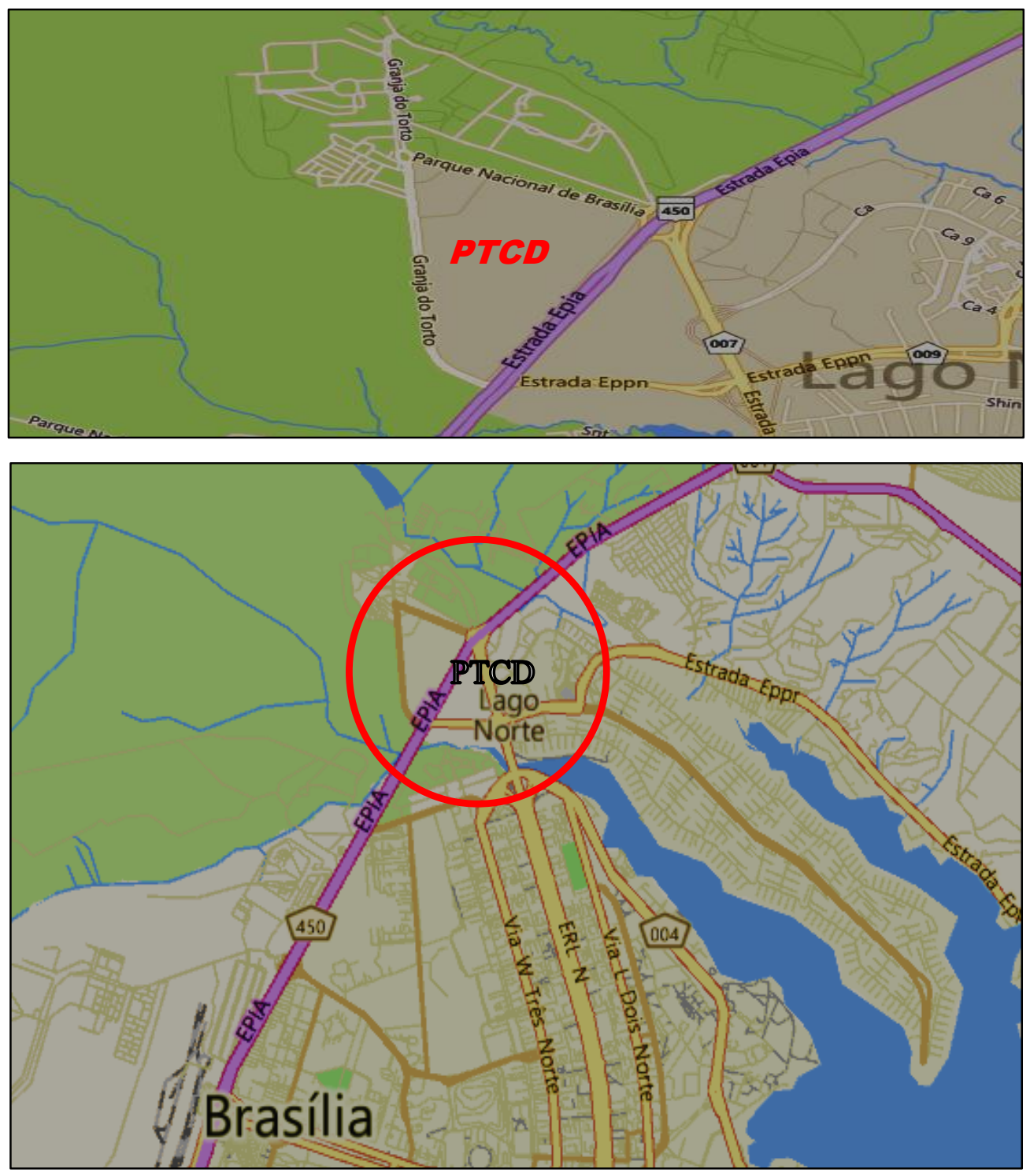

Figura 6.6 Localização do Parque Tecnológico Capital Digital

A imagem mostra a área do PTCD em formato de triângulo marcada em vermelho na figura. Em destaque na parte de cima da figura as delimitações pela Granja do Torto, o Parque Nacional de Brasilia e às margens da rodovia Epia Norte (DF-003).

Fonte: Google Earth (2016).

Em 20 de abril de 2006, o Decreto $\mathrm{n}^{\circ} 26.740$, criou o grupo executivo para a implantação do parque tecnológico com o objetivo de acelerar o processo. Em setembro de 2006, a Superintendência do Instituto Brasileiro do Meio Ambiente e dos Recursos Naturais Renováveis - IBAMA/DF expediu a licença prévia ao parque tecnológico em nome da TERRACAP. Este estabeleceu as regras de ocupação da área do parque estabelecendo as exigências e restrições. Foram determinadas a condições de infraestrutura tais como: abastecimento de água, drenagem pluvial e energia elétrica. $\mathrm{O}$ documento 
determinou ainda as diretrizes para o respeito a área do entorno do conjunto urbanístico de Brasília e do objeto do seu tombamento federal.

Estabelecidas as regras de instalação, em dezembro de 2006, foi destinada a área de $40.000 \mathrm{~m}^{2}$ para o DATACENTER para implementação de centro de dados do Banco do Brasil e da Caixa Econômica Federal. Em 2007 foi delimitado o terreno de 123 há com cercas e construções das calçadas na área do parque com a aprovação do projeto urbanístico.

Os projetos de infraestrutura (água, esgoto, pavimentação e drenagem) foram aprovados em 2008 com a licença de instalação emitida pelo IBAMA. O Quadro 6.4 sintetiza a cronologia destas ações de gestão para a implementação do parque tecnológico.

Quadro 6.4 Ações de Gestão no Parque Tecnológico Capital Digital (PTCD)

\begin{tabular}{|c|c|}
\hline Cronologia & Ação/Gestão \\
\hline 2002 & $\begin{array}{l}\text { - Lei Complementar no } 679 / 2002^{*} \text { autoriza a criação da Cidade Digital em área } \\
\text { próxima à Granja do Torto, dentro do Parque Nacional de Brasília. }\end{array}$ \\
\hline Set/2004 & $\begin{array}{l}\text { - Impasse processual é finalizado após envio de projeto ao Congresso Nacional } \\
\text { pelo Ministério do Meio Ambiente para expansão do Parque Nacional. }\end{array}$ \\
\hline 2006 & $\begin{array}{l}\text { - Projeto de expansão dos limites do Parque Nacional e criação do Parque } \\
\text { Digital é aprovado pelo Senado Federal. }\end{array}$ \\
\hline Dez/2006 & $\begin{array}{l}\text { - Área de } 40.000 \mathrm{~m}^{2} \text { destinada ao DATACENTER para implementação do } \\
\text { centro de dados do Banco do Brasil e a Caixa Econômica Federal. }\end{array}$ \\
\hline 2007 & $\begin{array}{l}\text { - Delimitação do terreno de } 123 \text { ha com cercas e construção de calçadas } \\
\text { CONPLAN e CLDF aprovam projeto urbanístico. }\end{array}$ \\
\hline 2008 & $\begin{array}{l}\text { - Aprovação dos projetos de infraestrutura (água, esgoto, pavimentação e } \\
\text { drenagem). } \\
\text { - Licença de instalação do IBAMA. }\end{array}$ \\
\hline 2009 & - A TERRACAP protocola pedido de registro da área no cartório de imóveis. \\
\hline
\end{tabular}

Fonte: elaborado pelo autor.

Assim, foi possível iniciar as obras do Parque Tecnológico Capital Digital. As obras tiveram início em novembro de 2009. A Figura 6.7 mostra a construção da estrutura do edifício do Complexo do Datacenter em agosto de 2011. A área não tinha sido cercada ainda e havia uma parte de infraestrutura dos escritórios da construção. 


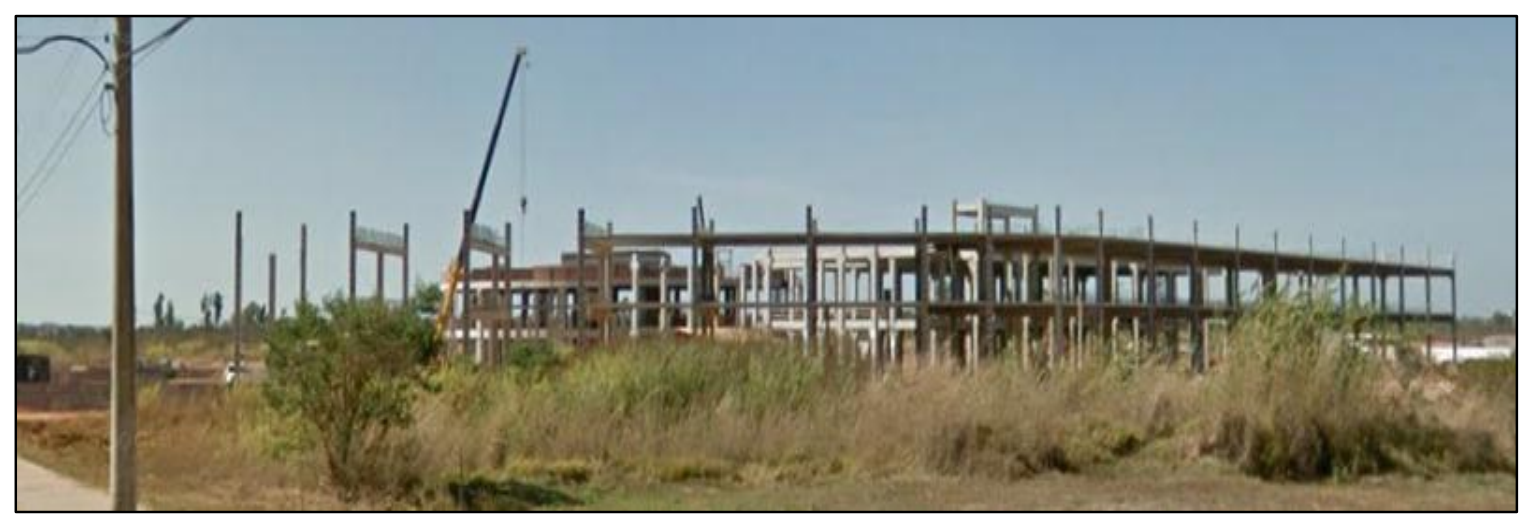

Figura 6.7 Início das obras no Parque Tecnológico Capital Digital

Mostra o início das obras no PTCD com a estrutura do edificio do Datacenter.

Fonte: Arquivo do autor.

Como já mencionado o Parque Tecnológico Capital Digital possui área total de 120 ha divididos em seis lotes, já descontadas as áreas de circulação implantadas, conforme discriminado no Quadro 6.5. A Figura 6.8 mostra a distribuição dos lotes na área do PTCD e os três acessos ao parque. Os acessos ao parque foram definidos como sendo o primeiro, a entrada principal pelo balão do Torto, nó de distribuição do tráfego em direção à saída norte de Brasília. A entrada secundária é na via de acesso ao Parque de Exposições da Granja do Torto, na porção sudoeste da área para atender o fluxo de veículos provenientes da EPIA (DF 003) e da via de ligação da saída do Lago Norte (EPPN - DF 009). A terceira entrada também localizada na via de acesso ao Parque de Exposições é destinada ao acesso de serviço por onde entram as cargas maiores e se concentra a área de serviços de apoio ao parque. A TERRACAP é a detentora e proprietária da totalidade da área e a empreendedora do parcelamento, especificamente do Lote 1, maior área com cerca de 96 hectares. 


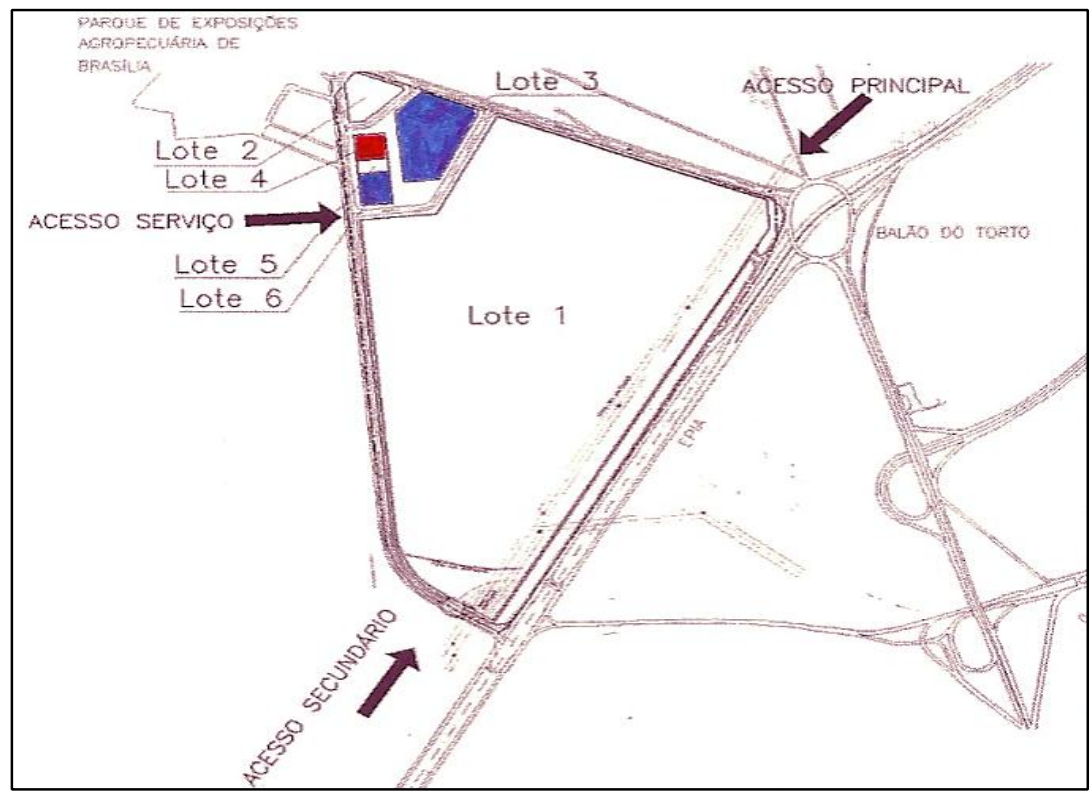

Figura 6.8 Distribuição dos lotes no PTCD

O croqui mostra a distribuição dos lotes na área do PTCD. As áreas em azul são as que já estão em funcionamento, os lotes 3 e 6 , respectivamente o Datacenter $B B / C E F$ e a subestação da CEB. Mostra ainda os três acessos ao parque. A área em vermelho é onde está sendo construído o prédio da governança do parque.

Fonte: Memorial Descritivo PTCD (TERRACAP, 2006)

O lote 1 conforme a Figura 6.8 possui $958.898,00 \mathrm{~m}^{2}$ sendo destinado para abrigar as empresas de tecnologia da informação e comunicação (TIC) que irá se instalar no parque. O projeto técnico do Parque Tecnológico Capital Digital prevê a instalação de empresas de base tecnológica nas áreas de tecnologia da informação e comunicação (TIC), biotecnologia e energia, tendo como objetivo a atração de empreendimentos em ciência e tecnologia; o estímulo ao desenvolvimento de empresas e produtos inovadores e competitivos; o incentivo ao capital humano e a inteligência de negócios; a promoção à cooperação entre instituições de ensino e pesquisa, empresas, órgãos públicos e os mercados. No projeto técnico são apresentadas as projeções do pórtico de entrada principal do PTCD e do prédio que abrigará as empresas do lote1 conforme Figura 6.9: 


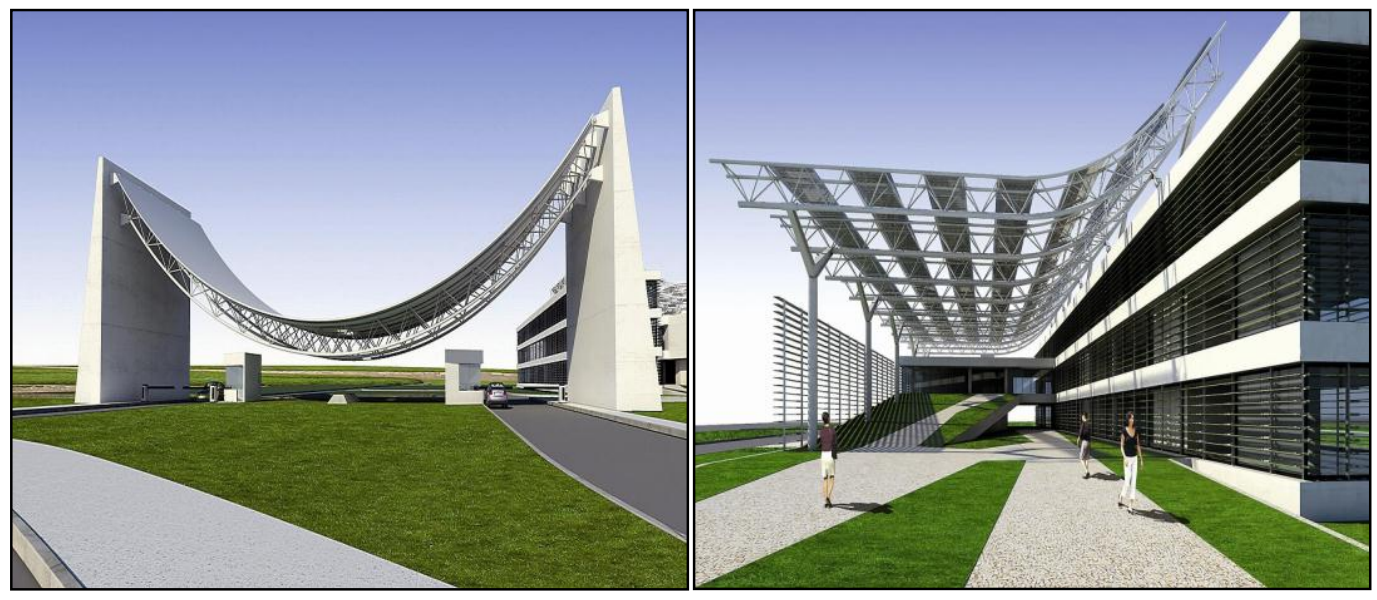

Figura 6.9 Projeção do pórtico de entrada e de prédio no projeto do PTCD

Mostra as projecôes da entrada principal do PTCD com uma ampla visão do horizonte e o prédio do edifício para a instalação das empresas de base tecnológica com projeto arquitetônico inovador.

Fonte: Memorial Descritivo PTCD (TERRACAP, 2006)

O Quadro 6.5 mostra a destinação dos lotes, as suas destinações se a situação deles em jan/2016. O lote 2 é destinado a instituições de ensino e pesquisa (E\&P). Os lotes 4 e 5 estão em fase de construção e são respectivamente a sede da governança do parque e o Datacenter do BRB.

Quadro 6.5 Lotes do Parque Tecnológico Capital Digital

\begin{tabular}{|c|c|c|}
\hline Lote (dimensão) & Destinação & Situação dez/2016 \\
\hline Lote $1-958 \mathrm{mil} \mathrm{m}^{2}$ & $\begin{array}{l}\text { Empresa de base tecnológica; } \\
\text { Centros de P\&D; } \\
\text { Infraestrutura de serviços de uso } \\
\text { comum }\end{array}$ & - \\
\hline Lote $2-14 \mathrm{mil} \mathrm{m}^{2}$ & Instituições de E\&P & - \\
\hline Lote 3-40 $\mathrm{mil} \mathrm{m}^{2}$ & $\begin{array}{l}\text { Datacenters do Banco do Brasil e } \\
\text { Caixa Econômica Federal }\end{array}$ & Implantado e em funcionamento \\
\hline Lote $4-6,4 \mathrm{mil} \mathrm{m}^{2}$ & Sede do PTCD & Em construção \\
\hline Lote $5-3.2 \mathrm{mil} \mathrm{m}^{2}$ & Datacenter do BRB & Em construção \\
\hline Lote $6-8 \mathrm{mil} \mathrm{m}^{2}$ & Subestação elétrica & Implantada e em funcionamento \\
\hline
\end{tabular}

Fonte: Adaptado de SINFOR, 2015.

Em outubro de 2006, os dois maiores bancos estatais do país, o Banco do Brasil e a Caixa Econômica Federal deram início ao processo de consulta pública para colher subsídios sobre a viabilidade de parceria público-privada na modalidade de concessão administrativa para gerenciar o seu complexo Datacenter em regime de co- 
location $^{86}$ no PTCD. Com um valor de investimento de R\$ 320 milhões o Datacenter é o primeiro empreendimento âncora do Parque Tecnológico Capital Digital (SINFOR, 2015). A Figura 6.10 traz imagem da maquete da sede do Datacenter composta por três edifícios interligados.

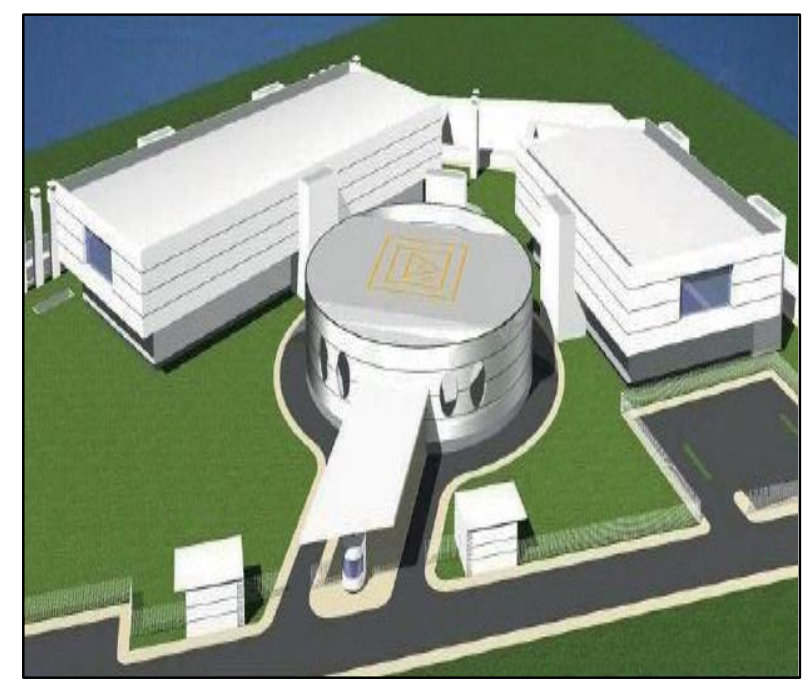

Figura 6.10 Maquete do Datacenter

O Datacenter é constituido de três edificicos, com cerca de cem quilômetros de fibras ótica.

Fonte: TERRACAP, 2013.

O consórcio responsável pelo Datacenter é o GBT formado pela GCE, a Termoeste e a BVA. O complexo Datacenter possui $25 \mathrm{mil} \mathrm{m}^{2}$ de área construída se constituindo num conjunto de edifícios destinado a abrigar e dar suporte aos equipamentos de tecnologia da informação dos dois bancos. Estes edifícios recebem a classificação máxima de segurança para complexos de processamentos de dados. As construções do complexo foram feitas sob normas internacionais e com as melhores práticas construtivas e de infraestrutura eletromecânica (SINFOR, 2015). A Figura 6.11 traz imagens da construção do Datacenter mostrando as obras de pavimentação e a fase final de acabamento do edifício sede em 2013.

${ }^{86}$ Co-location se refere aos espaços que abrigam simultaneamente os computadores e as redes de comunicação. 

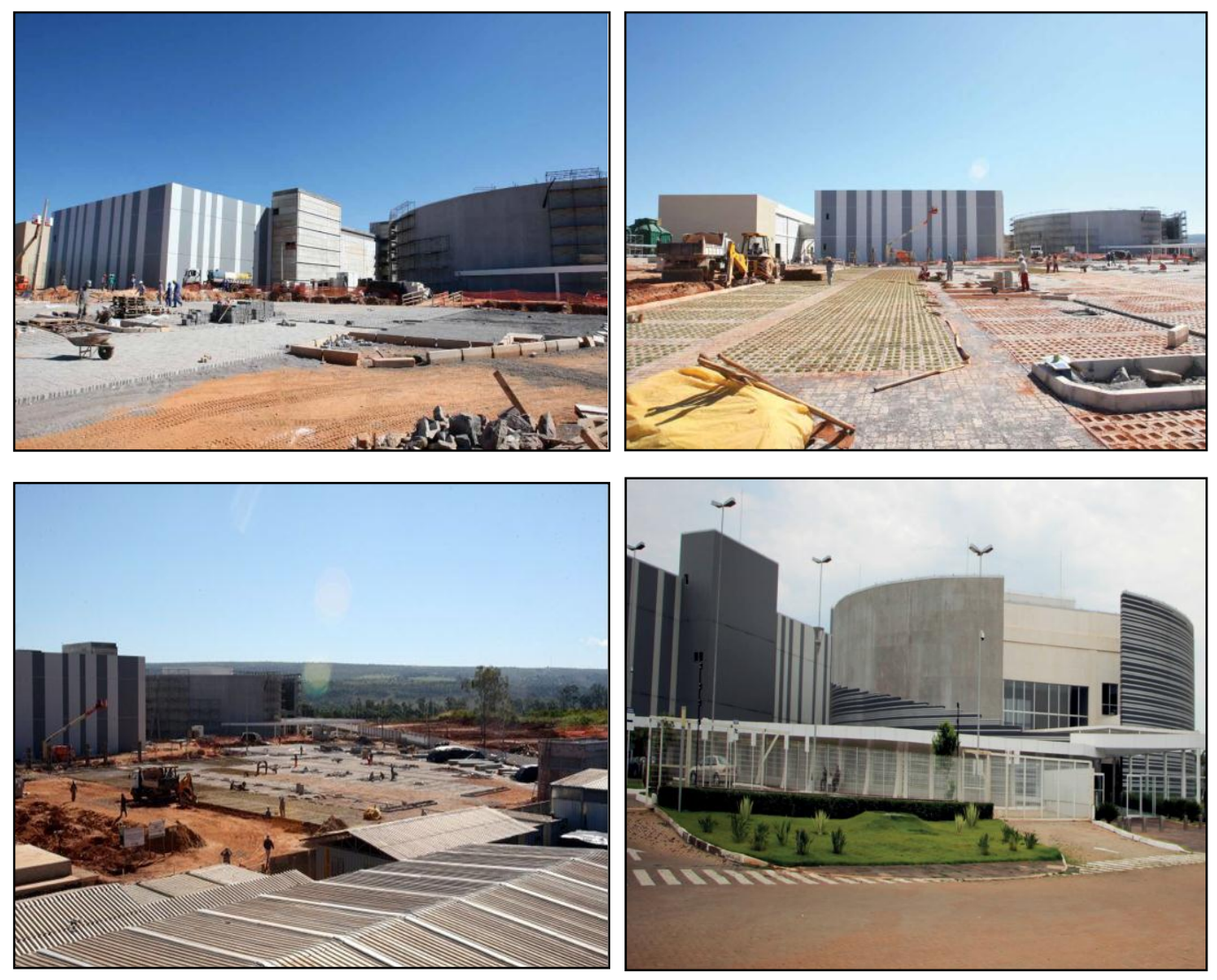

Figura 6.11 Fases da construção do Datacenter

Mostra fases da construção do Datacenter em 2013, (da esquerda para a direita) início da obras de pavimentação; colocaşão de blocos de concreto permeáveis; vista de cima da área dos estacionamentos em pavimentação; edificicio sede em fase final de acabamento.

Fonte: TERRACAP, 2013.

O Datacenter é constituído de três edifícios, com cerca de cem quilômetros de fibras ótica sendo, o primeiro deles, o bloco de infraestrutura que abriga os equipamentos que dão suporte aos equipamentos de TI; o segundo é o bloco de produção, construído no modelo do tipo bunker, para armazenamento e processamento dos equipamentos de TI e o terceiro que é o bloco de monitoramento conjugado com o prédio de quarentena dos equipamentos.

Em funcionamento desde 2013, o Datacenter do Banco do Brasil e da Caixa Econômica é responsável pelo armazenamento e proteção dos dados destas instituições bancárias. O complexo não produz inovações na área de tecnologia da informação e comunicação. A Figura 6.12 apresenta vista aérea atual do parque mostrando o padrão de edificação moderno do Datacenter e a integração dos três prédios que o constitui. Mostra ainda ao fundo a construção do edifício sede da governança em andamento. 


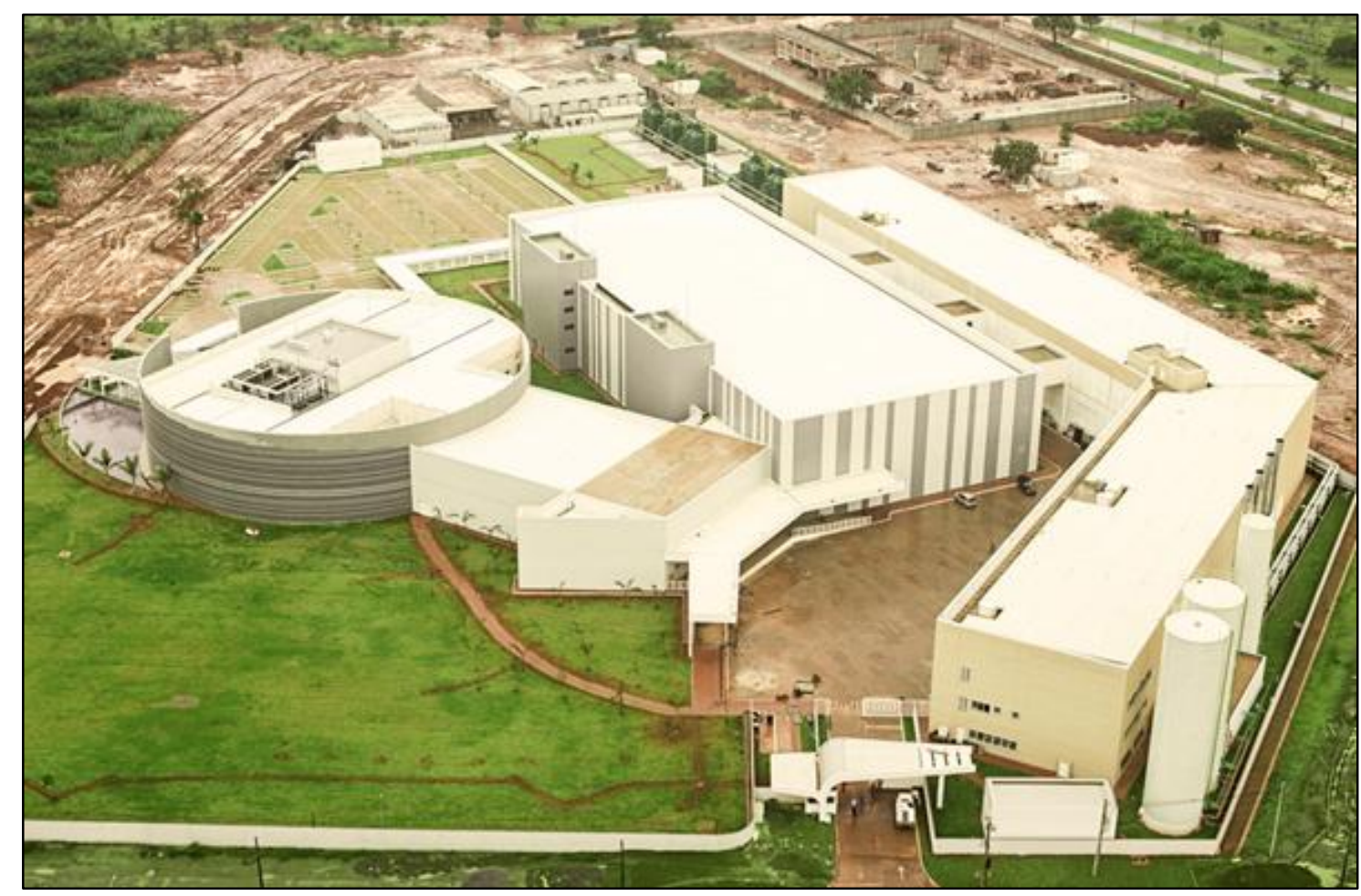

Figura 6.12 Complexo do Datacenter no PTCD

Mostra a vista aérea atual do parque mostrando o padrão de edificaşão moderno do Datacenter e a integração dos três prédios que o constitui. Mostra ainda ao fundo (canto superior direito) a construção do edificio sede da governança em andamento.

Fonte: TERRACAP (2015)

O Datacenter é considerado na atualidade o mais moderno do país segundo norma internacional que define o nível de segurança de 1 a 4 . O Datacenter instalado no parque tecnológico é de nível 4 (SINFOR, 2015). O complexo tem como objetivo garantir a continuidade e a expansão dos negócios dos dois bancos para o período de quinze anos, além da redução dos riscos operacionais e da normatização dos padrões internacionais da segurança de dados.

As Fotos 6.1 e 6.2 mostram em destaque a entrada do complexo do Datacenter. Podemos observar as condições de infraestrutura viária de acesso, sinalização, iluminação pública, paisagismo e coleta seletiva de resíduos. A entrada possui nível de segurança controlado por guarita externa e interna, além de sistema de monitoramento por câmeras em toda a extensão exterior do complexo. 

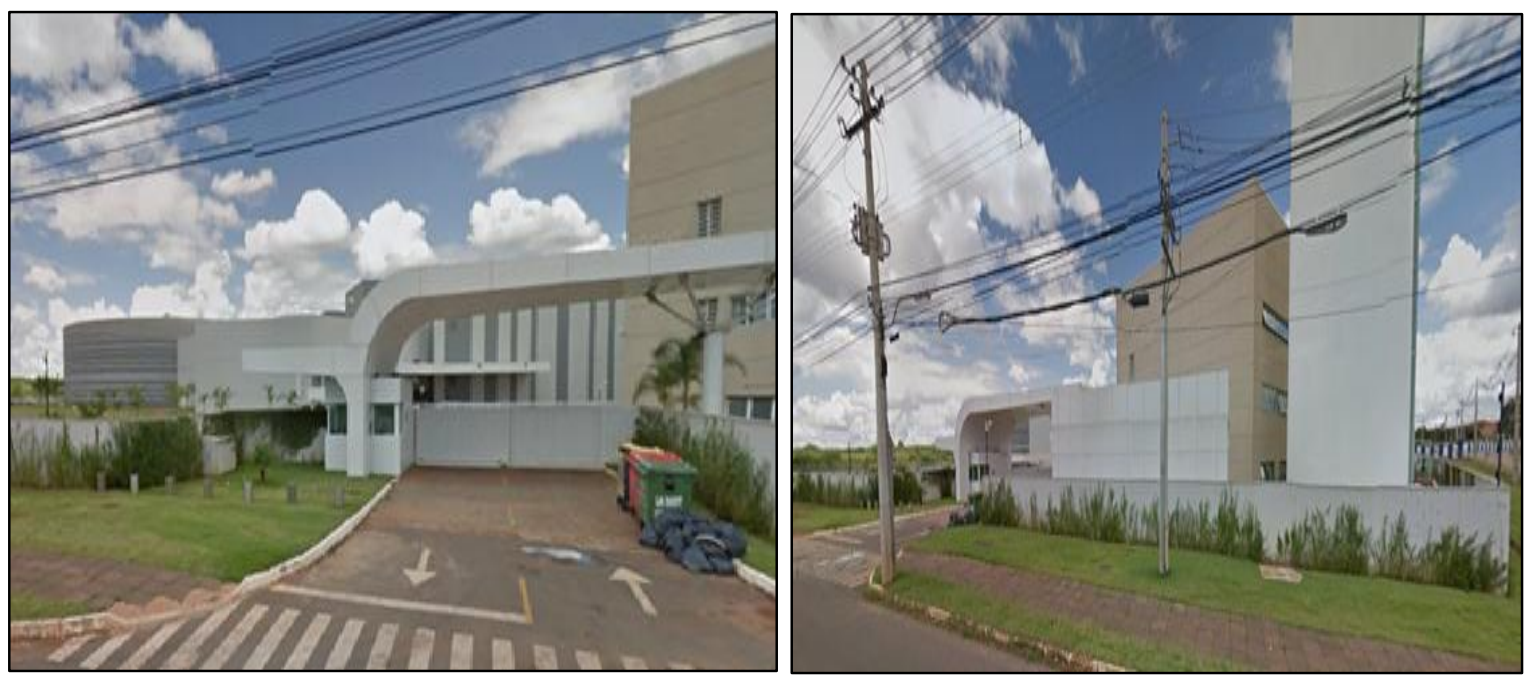

Fotos 6.1 e 6.2 Entrada do Complexo do Datacenter

Mostram a entrada do Complexo do Datacenter em funcionamento, com infraestrutura presente, como pavimentação, iluminação pública, sinalização. Observa-se ainda a coleta seletiva de resíduos.

Fonte: Arquivo do autor, 2016.

No lote 4 apresentado no Quadro 6.5 está sendo construído o edifício sede da Governança do Parque Tecnológico Capital Digital. A governança terá como principal atividade a gestão das empresas de TIC que irão se instalar no lote 1. A gestão será na forma de uma Sociedade de Propósito Específico - SPE, por meio de uma PPP, no qual o parceiro privado financia, elabora o projeto, promove a construção e opera uma ou mais instalações em troca do recebimento da receita gerada pelos serviços explorados por meio delas, durante um período de tempo determinado.

A equipe técnica da governança será composta por engenheiros, arquitetos, consultores de TI e outros profissionais. A SPE ficará responsável pelo controle e fiscalização sobre a execução de contratos referentes as instalações eletromecânicas, as instalações especiais de lógica, de telecomunicações, de segurança, manutenção predial e vigilância (TERRACAP, 2012). As Fotos 6.3, 6.4, 6.5 e 6.6 mostram as obras do prédio da governança em andamento no ano de 2013 e atualmente. 

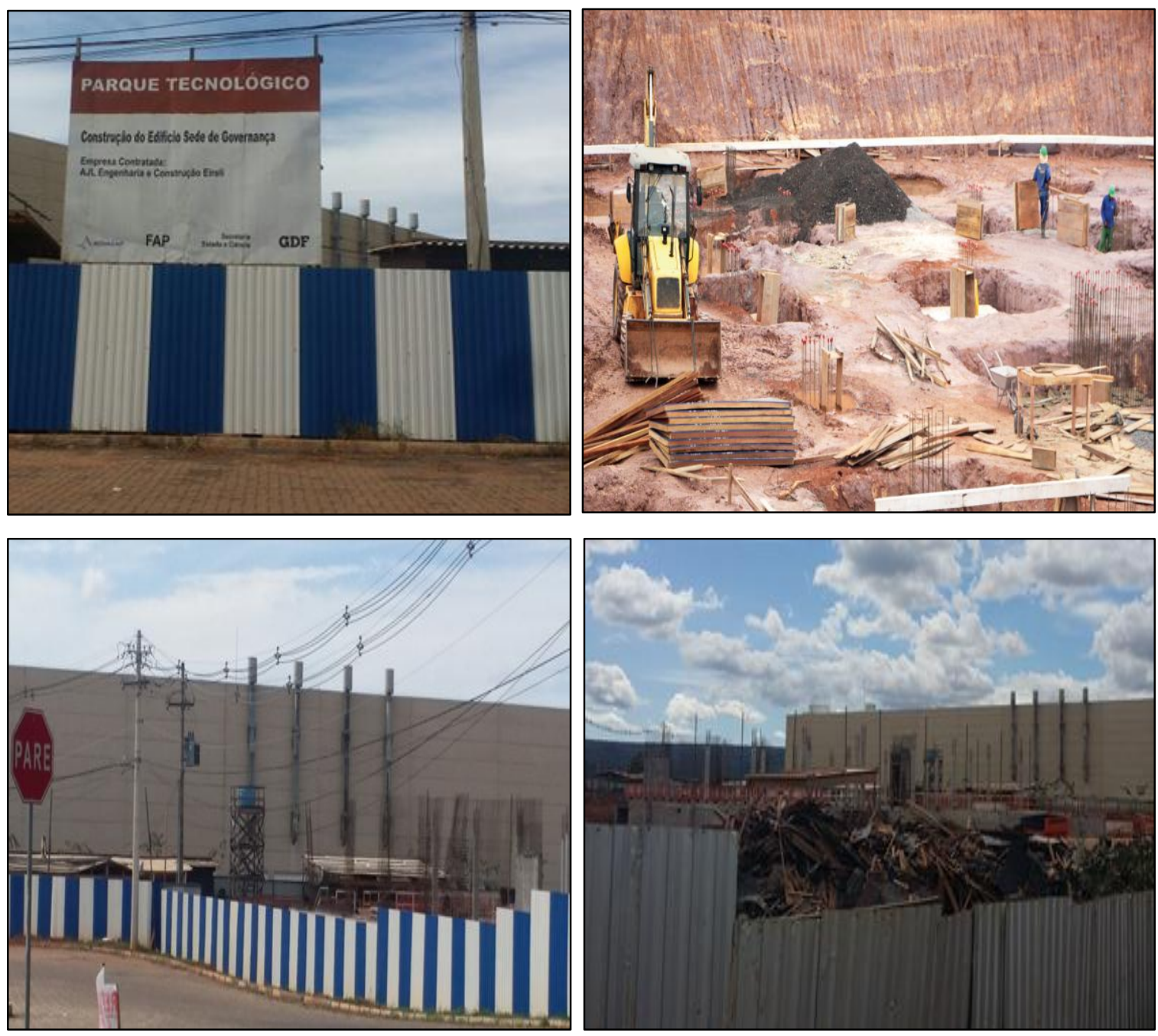

Fotos 6.3/6.4/6.5 e 6.6 Construção do edifício sede da Governança do PTCD

Mostram as obras de construção do prédio da Governança do PTCD. Da esquerda para a direita: placa de identificação da obra, observando-se a presença da FAP/DF no projeto; construção das fundações em agosto de 2013; atual fase com o levantamento da estrutura do prédio e vista pelo fundo do canteiro da obra mostrando a estrutura da edificação.

Fonte: Arquivo do autor, 2016.

A partir do funcionamento do prédio da Governança serão estabelecidas as empresas de porte médio, micro e pequenas empresas na área de tecnologia da informação e comunicação em parceria com as instituições de ensino e pesquisa, órgãos governamentais relacionados e a entidade gestora do parque. A distribuição das empresas será em camadas sendo uma primeira composta por centros empresariais voltados para atendimento de micro e pequenas empresas; uma segunda para situar as empresas e instituições de pesquisa de porte médio e uma terceira voltada para a localização das empresas de grande porte, que já está em funcionamento no PTCD e são as empresas âncoras (Complexo do Datacenter do Banco do Brasil e da Caixa Econômica Federal), na configuração apresentada na Figura 6.13. A localização das empresas na área do Parque 
Tecnológico Capital Digital segue a mesma configuração daquela apresentada na Figura 3.1 do Capítulo 3, apenas acrescentamos as setas como se fossem engrenagens para sugerir uma interação entre estas para os efeitos de spin-offs característicos de parques tecnológicos brasileiros.

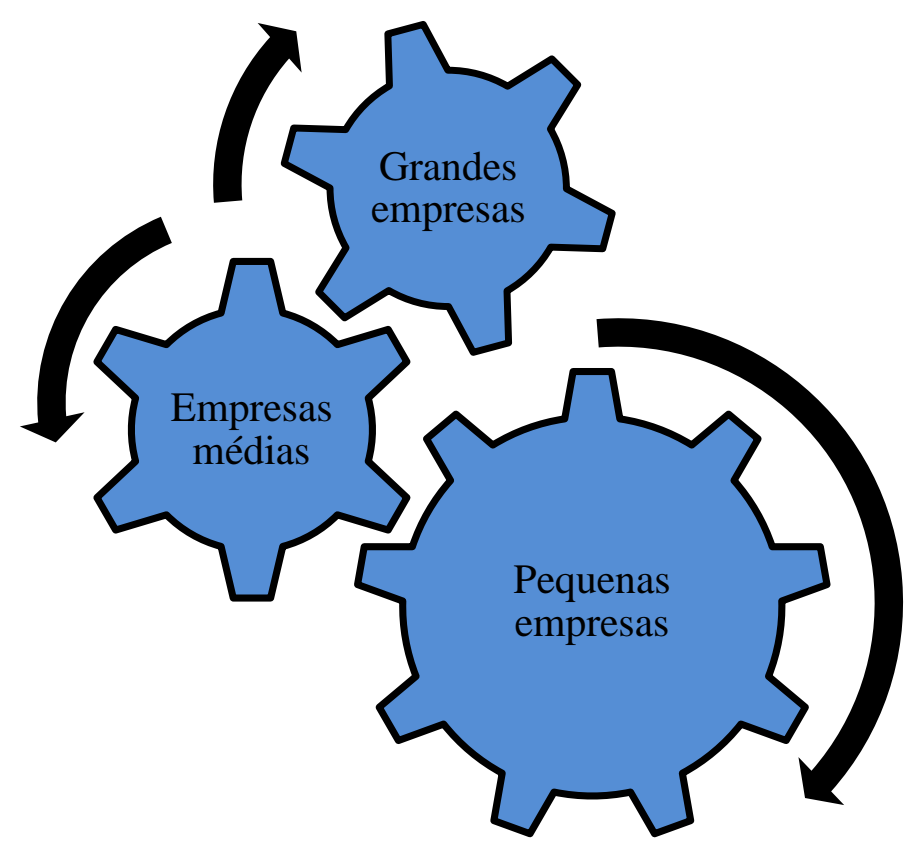

Figura 6.13 Distribuição espacial das empresas no PTCD

Mostra as três camadas de distribuição das empresas de TIC no PTCD. Observa-se que a camada maior será destinada as micro e pequenas empresas que geram as inovações. A terceira camada já está em funcionamento no PTCD que são as empresas âncoras (Complexo do Datacenter do Banco do Brasil e da Caixa Econômica Federal).

Fonte: Elaborada pelo autor.

A empresa pública empreendedora - TERRACAP já implementou a infraestrutura urbana, como amplas vias de acesso viário, estacionamentos, iluminação pública e capacidade energética compatível com o porte do local (subestação da CEB no lote 6) como pode ser visualizado na Figura 6.8. Após apresentarmos as características do Parque Tecnológico Capital Digital sob a ótica do planejamento e a sua implantação inicial, retomamos as questões levantadas no início deste tópico sobre a participação dos atores envolvidos. Quem são estes atores? Qual a participação destes atores no processo de implantação do PTCD? Quais as suas visões sobre o parque tecnológico? Quais as suas expectativas? 


\subsection{Intencionalidades dos atores no PTCD: desconstruindo o discurso institucional}

A inovação não pode ser vista como uma noção a-histórica, que se constituiria apenas numa etapa avançada na relação entre homem e natureza. Deve ser entendida como uma conquista da sociedade no processo histórico de domínio da natureza pelo homem, submetida ao regime de acumulação flexível. As inovações devem ser interpretadas como manifestações das relações técnicas de produção, as quais não podem ser dissociadas das relações entre os atores sociais, dado que ambas são partes do mesmo todo (FERREIRA, 1990, p.67). Assim, vamos entender o território como o conjunto de relações e interações entre os atores envolvidos em combinações espaço-temporais (SAQUET, 2007).

Para identificar os atores envolvidos no Parque Tecnológico Capital Digital vamos discorrer sobre a Teoria do Triângulo proposta por Sábato; Botana (1975) apud (OSÓRIO,1990, p. 238). O processo de inovação da estrutura produtiva de uma sociedade não é alcançada apenas, com base numa rigorosa infraestrutura científico-tecnológica, visto que a inovação é um processo político que sofre a intervenção de diversos fatores como a estrutura econômico-financeira da sociedade e das empresas, a mobilidade social, a tradição, o perfil dos atores dirigentes, o sistema de valores da sociedade e os mecanismos de comercialização, os quais se traduzem em forças que impedem ou impulsionam o processo de inovação.

O processo de desenvolvimento científico tecnológico constitui o resultado da ação múltipla e coordenada de vários atores envolvidos. Sábato; Botana (1975) apud (OSÓRIO, 1990, p. 238) estabelecem que entre esses atores existe um sistema de relações que poderia ser representado pela figura geométrica de um triângulo, no qual cada um deles ocuparia um dos vértices dessa.

Na descrição da Teoria do Triângulo, o vértice do governo ${ }^{87}$ compreende o conjunto de instituições que têm como objetivo formular e implementar políticas públicas e mobilizar recursos para os vértices da estrutura produtiva e da infraestrutura científicotecnológica, através de processos legislativos e administrativos. O papel do governo no desenvolvimento científico-tecnológico seria equacionado em três tipos de intervenções: a) como regulador da concorrência através de normas jurídicas sobre a propriedade

\footnotetext{
${ }^{87}$ Compreendido como o ente que representa o poder do Estado e exerce a Governance sobre o território usado, ou seja, a capacidade de tomar decisões com habilidade e criação de práticas cooperativas entre os atores.
}

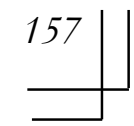


intelectual; b) como dinamizador de pesquisa e desenvolvimento; c) como produtor direto de ciência e tecnologia (OSÓRIO, 1990, p. 238).

$O$ vértice da estrutura produtiva representa o conjunto de setores produtivos responsáveis pelos bens e serviços demandados pela sociedade. O outro vértice compreende o sistema educacional que forma os indivíduos/sujeitos que protagonizam as atividades de pesquisa, os laboratórios, institutos e centros de pesquisa e desenvolvimento, o sistema de planejamento, promoção, coordenação e estímulo à pesquisa (conselhos de pesquisa, academia de ciência) os mecanismos jurídico-administrativos que regulam as instituições de pesquisa e os recursos financeiros aplicados ao seu funcionamento.

Segundo Figueiredo (1993, p. 87), os vértices da figura geométrica estão caracterizados funcionalmente evitando a localização errônea dos atores nos vértices. Cada vértice representa uma convergência de múltiplas instituições, unidades de decisão e de produção que se relacionam através de múltiplas dimensões e produzem a dinâmica de relações sociais no triângulo.

$\mathrm{O}$ vértice do governo compreende os seguintes atores: administradores, governantes, secretários e ministros de Estado. O discurso desses atores em relação ao desenvolvimento de inovações é de que cabe ao Estado regular e prover o desenvolvimento técnico-científico, bem como normatizar o sistema de pesquisa. A estrutura do triângulo para muitos deles não é lembrada como uma relação interorganizacional e sim como a pirâmide, no qual o poder estatal está no ápice.

O vértice da estrutura produtiva está representado pelos industriais, empresários e empreendedores. Para estes, as inovações são fundamentais para o crescimento das empresas e o respectivo acúmulo de capital. Alguns acreditam que uma empresa para crescer necessita de concorrência, ou segredos inovadores para manter-se no mercado. Por isso, as inovações são vistas por estes, como mecanismos de concorrência.

$\mathrm{O}$ vértice da infraestrutura de ciência e tecnologia, compreende os tecnólogos, cientistas, administradores de empresas estatais. Nesse vértice, observa-se um consenso maior de opiniões. As inovações são fundamentais para o crescimento econômico, proporcionando a disponibilidade de bens e serviços, gerando empregos, renda e, a redução das desigualdades no território usado.

Aplicando o modelo ao Parque Tecnológico Capital Digital, na prática, as relações parecem situar-se apenas entre atores do mesmo vértice. Mas, de outro modo, nos leva a ressaltar, que a interação entre os atores é muito forte em todas as direções e 
mutuamente. Isso deve-se ao fato, que as interações são resultados da ação destes, de suas intencionalidades como se verá adiante. Todos vivem em sociedade, divulgando, transferindo suas ideias. A Figura 6.14 mostra os atores envolvidos no Parque Tecnológico Digital. Observa-se que são os mesmos agentes da Figura 6.1 do início deste Capitulo, mas esta abaixo representa a interação mostrando o fluxo que existe em todas as direções do triângulo.

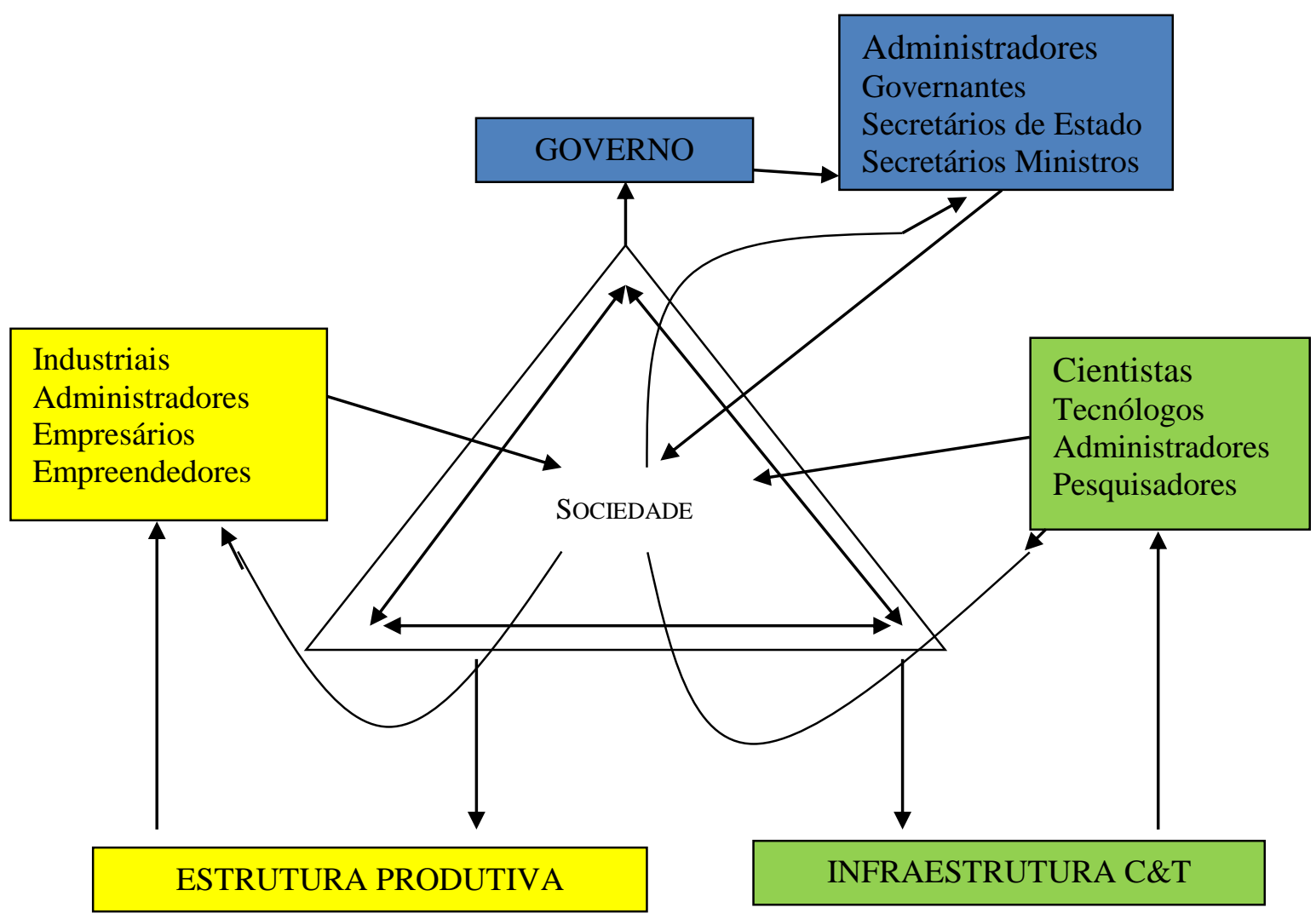

Figura 6.14 Os atores envolvidos no PTCD.

A figura mostra uma interação entre os atores envolvidos em todas as direções. A Teoria do Triângulo afirma que essas interaçoes dos atores podem ser no mesmo vértice ou com atores dos outros vértices.

Fonte: Elaborado pelo autor.

A interação entre os interessados é motivada pelo contexto social no qual estão inseridos. Existe por trás dos discursos destes atores uma ideologia de um determinado segmento social. Maillat (1992) afirma que estes discursos dizem respeito aos recursos imateriais no processo de inovação, ou seja, as relações/interações entre os sujeitos/ atores com suas visões, intencionalidades. 
Após o reconhecimento de quem são os atores envolvidos na consolidação do PTCD no território usado vamos discorrer sobre as suas intencionalidades tentando ir além da materialidade do objeto e a sua significação, mas buscar o significado que o sujeito/ator lhe dá, de acordo com suas vivências. A intencionalidade é consequência do "vivido". De acordo com Santos (2006, p. 58) é o resultado da relação entre o homem e mundo, entre o homem e o seu entorno. A ação humana é um acontecimento de consciência que tem o caráter de intencionalidade.

Assim, o sujeito e o objeto criam-se mutuamente numa empiricidade onde sob a ação da forma revelam-se no evento. Santos (2006, p. 60) que à intencionalidade da ação se conjuga as intencionalidades dos objetos e ambos são hoje dependentes da respectiva carga de técnica presente no território usado. Até este ponto privilegiei nesta Tese, a tecnosfera de Milton Santos, o mundo dos objetos, da acumulação flexível ${ }^{88}$ e o seu meio técnico-científico ${ }^{89}$. Agora pretendo trazer o sujeito/ator ao centro deste debate. É a vez do vivido, das percepções do sujeito. Retomo o conceito psicosfera de Santos (2006, p. 171) o reino das ideias, crenças, paixões e lugar da produção de um sentido.

Dessa forma, para a elucidação das duas questões de pesquisa da Tese acrescentamos uma metodologia para a compreensão dos "eventos" no território usado do Parque Tecnológico Capital Digital - PTCD. Entender quais são as intencionalidades dos atores envolvidos na consolidação do Parque Tecnológico Capital Digital e quais as suas ações para a implementação do parque no território usado é o que nos propomos a tentar esclarecer.

Vamos tentar estabelecer a ocorrência dos fenômenos apresentados na teoria com o conhecimento obtido da realidade do estudo de caso por meio das entrevistas e do trabalho de campo. Para a operacionalização disso, buscou-se a aplicação de entrevista semiestruturada. A escolha da entrevista semiestruturada deve-se ao fato de ser um método mais eficiente que o questionário no levantamento de dados qualitativos. A entrevista semiestruturada permite o contato entre entrevistado e entrevistador, podendo este formular perguntas a partir do entrevistado, possibilitando maior espaço para questões abertas (HAIR et al, 2005, p. 160).

\footnotetext{
${ }^{88}$ Os espaços na acumulação se definem segundo Santos (2006, p. 173) pela presença conjunta, indissociável de uma tecnosfera e de uma psicosfera, funcionando de modo unitário.

89 Importante mencionar nas palavras de Santos (2006, p. 171) que tecnosfera e psicosfera são redutíveis uma à outra, são dois pilares com os quais o meio técnico-científico introduz a racionalidades, a irracionalidade e a contra-racionalidade no próprio conteúdo do território e os parques tecnológicos como formas desta dimensão. Ver discussão no Capítulo 02.
} 
A entrevista semiestruturada permite identificar o perfil do entrevistado, agrupar as respostas em busca de padrões nos dados e ao mesmo tempo uma estrutura de respostas devido às questões abertas. Nas discussões que se seguem foram utilizados dados primários e secundários. Os dados primários são aqueles obtidos através das entrevistas semiestruturadas realizadas pelo pesquisador, visto que foram entrevistados pessoalmente alguns dos envolvidos no Parque Tecnológico Capital Digital. Os dados secundários são aqueles não coletados nas entrevistas pessoais, mas sim da análise documental, livros e artigos para auxiliar na pesquisa.

Para a realização das entrevistas semiestruturadas foi elaborado um roteiro de análise constante no anexo desta Tese, com perguntas comuns a todos os atores envolvidos e outras mais específicas para compreensão de eventos pertinentes a cada segmento. As entrevistas foram realizadas com gestores governamentais, empresários, pesquisadores, moradores da comunidade local (Vila Weslian Roriz), trabalhadores da construção civil atuantes no parque e moradores da RAXXIII - Varjão. As entrevistas foram realizadas para a aproximação conceitual com a realidade para responder as duas questões de pesquisa desta Tese. Buscou-se nas entrevistas identificar possíveis intencionalidades destes atores. Foram escolhidos gestores governamentais diretamente ligados à Ciência e Tecnologia no Distrito Federal, sendo um deles participante do projeto inicial do PTCD. O objetivo de entrevista-los era a compreensão do discurso institucional referente ao Parque Tecnológico Capital Digital.

Os empresários (incluindo proprietários, sócios ou gerentes) escolhidos para as entrevistas são do setor de tecnologia da informação e comunicação (TIC) e alguns deles já haviam passado pela incubadora de empresas do CDT/UnB. As áreas de atuação das suas empresas de acordo com o $\mathrm{CNAE}^{90}$ atividades econômicas do terciário avançado conforme IBGE: atividades dos serviços de tecnologia da informação; atividades de prestação de serviços da informação e; e outras atividades profissionais, científicas e técnicas. O setor predominante entre os entrevistados é o de atividades de serviços de tecnologia da informação. As empresas estão localizadas no Lago Norte, Asa Norte, Setor de Indústria e Abastecimento - SIA e Setor Comercial Norte - SCN. As empresas dos entrevistados são microempresas, pequena empresa, média e grande empresa. Na maioria dos entrevistados a empresa quanto ao tamanho é microempresa (até 29 funcionários). O quadro de funcionários das empresas é composto em sua maioria por profissionais com nível superior

\footnotetext{
90 Terminologia de atividades econômicas CNAE - Classificação Nacional de Atividades Econômicas do IBGE (2016).
} 
completo. Os empresários informaram que o alcance dos produtos de suas empresas é de abrangência nacional. Possuem como clientes em sua maioria o setor público.

Os pesquisadores foram escolhidos com base no conhecimento sobre o Parque Tecnológico Capital Digital, publicações e participação no projeto do parque. Os moradores da comunidade local e os trabalhadores da construção civil foram escolhidos para serem entrevistados pela proximidade ao PTCD. Os moradores da RA XXIII - Varjão foram escolhidos pela proximidade das vias de acesso ao PTCD e para comparar suas visões com a dos moradores locais.

As entrevistas com os gestores governamentais, empresários, sócios ou gerentes e pesquisadores foram realizadas com agendamento prévio por meio de contato de telefônico direto com o entrevistado ou por intermédio dos sindicatos que realizavam os agendamentos. Foi estabelecida para as entrevistas uma amostra com vinte e cinco entrevistados possíveis, universo esse coerente para a obtenção de dados qualitativos da realidade. Destes três foram respondentes do governo; dois da infraestrutura de Ciência e Tecnologia (pesquisadores), cinco moradores locais e trabalhadores do parque e; quinze da estrutura produtiva (empresários, sócios ou gerentes). Neste último segmento, duas entrevistas não foram realizadas reduzindo esta amostra para treze e o universo total para vinte e três entrevistados. As entrevistas ocorreram durante os meses de abril e maio de 2016. Vejamos os registros dessas visões.

Quando os entrevistados foram perguntados se sabiam o que era o Parque Tecnológico Capital Digital, a maioria deles afirmaram não saber, sendo que deste total a maioria eram empresários do setor de Tecnologia da Informação e Comunicação (TIC). Em complementaridade ao questionamento, um dos entrevistados do segmento Governo demonstrou que o foco do PTCD são as empresas de TIC quando perguntado sobre qual é o objetivo do parque conforme trecho abaixo:

O PTCD tem por objetivo o desenvolvimento de uma nova matriz produtiva para Brasília, tendo como foco o empresariado local de TIC. ${ }^{91}$

A formação de um centro de excelência especializado em tecnologia da informação com elevados índices de sustentabilidade. ${ }^{92}$

Dos trechos das entrevistas podemos inferir que o desconhecimento pela maioria dos empresários de TIC sobre o PTCD não chega ao conhecimento do gestor, pois

\footnotetext{
91 Entrevista concedida pelo Gestor C, em abril de 2016.

92 Entrevista concedida pelo Gestor A, em maio de 2016.
} 
este fala que as empresas de TI são o foco do PTCD. Inferimos ainda da fala do entrevistado gestor A, um discurso institucional elogioso, tendo em vista como se verá adiante, o parque se encontra em área com vulnerabilidade ambiental e a sua implementação pode ter provocado impactos no ambiente.

Vejamos na sequencia o depoimento de um empresário de TIC sobre o objetivo do Parque Tecnológico Capital Digital:

A localização de empresas de tecnologia e informação no mesmo lugar para conseguir melhores incentivos fiscais e crescer a economia local gerando muitos empregos. ${ }^{93}$

O trecho da entrevista mostra a visão dos empresários sobre a importância na concessão de incentivos fiscais às empresas para o crescimento da economia e a geração de empregos. Importante assinalar que a maioria dos empresários de TI entrevistados afirmou que a concessão de incentivos fiscais por parte do Governo como o fator mais importante para instalação de suas empresas no Parque Tecnológico Capital Digital. Comparando as falas dos gestores governamentais e dos empresários podemos inferir que ambos têm suas visões voltadas para o desenvolvimento econômico.

Vejamos os trechos das entrevistas com os moradores locais da Vila Weslian Roriz, dos moradores do Varjão e do trabalhador no parque quando perguntados para que serve o parque tecnológico:

No início eu vi um monte de caminhão trazendo material e cercando a área aí em frente. Só depois colocaram uma placa dizendo que era um parque tecnológico. Eu sei que é coisa de tecnologia dos bancos. Ficou muito tempo sem fazer nada (as obras), ficava tudo parado. Uns três anos atrás foi que começaram as obras e aí depois acho que inaugurou do lado de lá ${ }^{94}$. Também demorou um tempo para construir a estação da CEB aí em frente..$^{95}$

É um parque tecnológico, produz tecnologia. Demorou muito para construir e não está pronto, dá para ver. Tem o barulho das obras todo dia e o entra e sai de caminhões. ${ }^{96}$

\footnotetext{
${ }^{93}$ Entrevista concedida por empresário do setor de TI, em maio de 2016.

${ }^{94}$ Se refere ao lado que fica em frente ao parque de exposições da Granja do Torto e que é a entrada principal do Datacenter do Banco do Brasil e da Caixa Econômica Federal.

${ }^{25}$ Entrevista concedida pelo Morador A, da Vila Weslian Roriz, que fica em frente ao PTCD, em abril de 2016.

${ }^{96}$ Entrevista concedida pelo Morador B, da Vila Weslian Roriz, que fica em frente ao PTCD, em abril de 2016.
} 
É um parque tecnológico. Sei porque trabalho em empresa lá do $\mathrm{CA}^{97}$ e já vi o pessoal falando que querem mudar a empresa para lá, que vai ser mais barato o aluguel, que só vai ter empresa de tecnologia. Eu não sei se vou querer trabalhar lá não. É longe daqui de casa e nem sei se tem ônibus para lá. ${ }^{98}$

Nunca ouvi falar e não sei onde é..$^{99}$

Aqui é um parque tecnológico. Mexe com os dados da Caixa. Trabalho aqui desde 2013 e venho lá de Samambaia para cá. A maioria (trabalhadores) vem de Planaltina e Águas Lindas trabalhar aqui. Estamos construindo a administração ${ }^{100}$ do parque agora. Vai ficar muito bonito quando ficar pronto, eu vi a maquete. ${ }^{101}$

Estas falas apresentam uma diferenciação se comparados com os dos segmentos de empresários e governo. Elas vão de encontro com aquilo que estamos querendo entender. As vivências do ator no território usado. São intencionalidades que segundo Santos (2006) aproximam os atores do seu entorno, daquilo que os cerca, um território apropriado. Os moradores A e B da Vila Weslian Roriz expressam em suas falas as percepções que tem do território usado que os cerca. Conseguem ver despretensiosamente o desenrolar dos eventos no território usado.

$\mathrm{Na}$ fala do trabalhador da construção civil inferimos a aparência espacial que ele tem do território usado e a paisagem, quando o mesmo afirma que o prédio da Governança do PTCD vai ser bonito. Pois bem, o mesmo se encontra num canteiro de obras sob sol escaldante, mas tem o entendimento subjetivo que o local será outro cenário no futuro. Este trabalhador de forma inconsciente lança-se com um observador do território usado e exprime na entrevista a sua percepção e abstração ao evento futuro "(...) vai ficar muito bonito quando ficar pronto."

Quanto aos moradores da RAXXIII - Varjão ${ }^{102}$ justifico as razões para a sua escolha nas entrevistas. A RAXXIII está localizada às margens da rodovia de acesso ao PTCD. Assim, vamos tentar comparar as visões destes moradores com as visões dos moradores da comunidade local Weslian Roriz próxima ao PTCD.

A entrevista com a moradora $\mathrm{C}$ sugere que seu conhecimento sobre o parque reside no fato de trabalhar numa empresa de TI, pois o outro morador D desconhece sobre

${ }^{97}$ CA é o Centro de Atividades localizado no Lago Norte - RA XVIII.

${ }^{98}$ Entrevista concedida pela Moradora C, da RAXXIII - Varjão, em abril de 2016.

${ }^{99}$ Entrevista concedida pelo Morador D, da RAXXIII - Varjão, em abril de 2016.

${ }^{100}$ Se refere ao prédio da Governança, ver no início deste Capítulo.

${ }^{101}$ Entrevista concedida pelo trabalhador da construção civil que trabalha nas obras do PTCD, em maio de 2016.

102 A RAXXIII - Varjão é apontada por Costa; Peluso (2016, p.16) como a cidade com maior índice de vulnerabilidade do território metropolitano de Brasília. 
o PTCD. Dessa forma, a inserção destes atores é para compreender se há alguma abrangência do PTCD na dinâmica do seu entorno imediato. Comparando as falas dos moradores do Varjão com as da Vila Weslian Roriz infere-se que estas últimas apresentam maior conhecimento sobre o PTCD, no sentido do reconhecimento desta forma espacial. Assim, podemos inferir que o morador da comunidade local Vila Weslian Roriz tem uma visão mais próxima do PTCD pois o mesmo o percebe em seu cotidiano.

Um outro aspecto trazido pelas entrevistas foi o perfil do profissional que trabalha no parque tecnológico. Quando perguntados sobre quais profissionais que trabalham no parque ao representantes nas entrevistas da comunidade local Vila Weslian Roriz, da comunidade do Varjão e o trabalhador do parque foram ouvidas as seguintes falas abaixo:

Acho que tem gente de todas as áreas, mas o movimento não é muito grande não. Vejo poucos carros aqui. Deve ser pessoal formado em computação. ${ }^{103}$

Pessoal formado em computação e engenheiros. ${ }^{104}$

\section{Pessoal com curso superior igual ao pessoal lá do trabalho. ${ }^{105}$}

Não sei. ${ }^{106}$

O pessoal tem nível superior, tem engenheiro, administrador, advogado. ${ }^{107}$

Estas falas sugerem que quando se trata de inovações tem-se pré-estabelecido a presença de profissionais qualificados. Exceto o morador D, do Varjão que não soube opinar. Em complementaridade ao entendimento de mão de obra no PTCD foi perguntado a estes atores se trabalhariam no PTCD. Vejamos os trechos das respostas:

Com certeza trabalharia, fica aqui de frente de casa. Seria muito bom. Mas tenho nível médio, não tenho estudo para trabalhar aí. Sou comerciante e trabalho na feira do produtor de Planaltina/DF. ${ }^{108}$

Trabalharia sim. Perto de casa seria muito bom, mas só tenho nível médio de escolaridade. Estou desempregado no momento. ${ }^{109}$

\footnotetext{
${ }^{103}$ Entrevista concedida pelo Morador A, da Vila Weslian Roriz, em abril de 2016.

${ }^{104}$ Entrevista concedida pelo Morador B, da Vila Weslian Roriz, em abril de 2016.

${ }^{105}$ Entrevista concedida pela Moradora C, da RAXXIII - Varjão, em abril de 2016.

${ }^{106}$ Entrevista concedida pela Morador D, da RAXXIII - Varjão, em abril de 2016.

${ }^{107}$ Entrevista concedida pelo trabalhador da construção civil que trabalha nas obras do PTCD, em maio de 2016.

${ }^{108}$ Entrevista concedida pelo Morador A, da Vila Weslian Roriz, em abril de 2016.
} 
Trabalharia sim. Só não sei como faria para pegar ônibus para lá. Tenho nível médio e trabalho para empresa de conservação e limpeza. ${ }^{110}$

Não trabalharia lá. Não tenho estudo, fiz só o fundamental (ensino) e trabalho aqui no lava jato. ${ }^{111}$

Não tenho estudo. Tenho somente o nível médio e trabalho para a construtora daqui do parque. ${ }^{112}$

Os trechos das falas dos atores acima sugerem que o Parque Tecnológico Capital Digital demanda por mão de obra qualificada como esboçamos no Capítulo 3 desta tese e esta concepção está em seu imaginário pois sugestionam os entrevistados não possuírem a escolaridade que o parque demandaria. Em outro trecho a moradora $\mathrm{C}$ fala ainda do deslocamento até o Parque Tecnológico Capital Digital por meio de transporte coletivo. Importante mencionar que a acessibilidade ao sistema de transportes foi citada pelo empresários de TI entrevistados com um dos fatores que levariam as suas empresas se instalarem no PTCD. Observa-se também que há o predomínio de ocupações altamente qualificadas nos parques tecnológicos, mas os modelos de parques tecnológicos brasileiros apresentados no Capítulo 4 e este PTCD apresentam em seus projetos Governanças que oferecem serviços de manutenção, conservação, limpeza e vigilância que demandam treinamento e mão de obra menos qualificada

Aos pesquisadores entrevistados foram realizados questionamentos mais específicos do Parque Tecnológico Capital Digital, como a importância do Centro de Apoio ao Desenvolvimento Tecnológico da Universidade de Brasília (CDT/UnB) para o PTCD e a localização das empresas de TIC em Brasília. Quando questionados sobre o papel do CDT/UnB no PTCD um deles afirmou a sua importância conforme trecho abaixo:

O CDT/UnB foi pioneiro no setor de inovação no DF. A incubadora do parque consolidou ao longo dos anos inúmeras empresas de base tecnológica. Se o PTCD estivesse em funcionamento, estas empresas teriam um centro de produção de inovação específico. $\mathrm{O}$ projeto do PTCD foi idealizado na época em parceria do CDT/UnB, da TERRACAP e da Secretaria de Ciência e Tecnologia do Distrito Federal. Quando o PTCD estiver em pleno funcionamento o CDT/UnB será a incubadora de empresas que poderão a vir se instalar nele. O CDT/UnB também produz

\footnotetext{
${ }^{109}$ Entrevista concedida pelo Morador B, da Vila Weslian Roriz, em abril de 2016.

${ }^{110}$ Entrevista concedida pela Moradora C, da RAXXIII - Varjão, em abril de 2016.

${ }^{111}$ Entrevista concedida pela Morador D, da RAXXIII - Varjão, em abril de 2016.

${ }^{112}$ Entrevista concedida pelo trabalhador da construção civil que trabalha nas obras do PTCD, em maio de 2016.
} 
pesquisas científicas que podem interessar às empresas instaladas no PTCD. ${ }^{113}$

Este trecho da entrevista com o pesquisador sugere a importância do CDT/UnB no processo de produção de inovação no Distrito Federal conforme apresentamos no tópico 6.2 deste Capítulo. O trecho da entrevista sugere ainda, que o CDT/UnB pode vir a ser a incubadora de empresas do PTCD. Foi perguntado também ao pesquisador onde estão localizadas as empresas de TI no Distrito Federal, respondendo o entrevistado o seguinte:

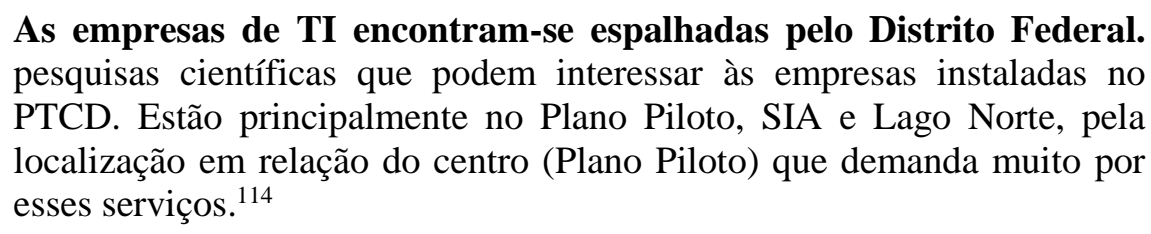

A fala do entrevistado sugere a concentração das atividades na área central de Brasília como abordado no Capítulo 5. As atividades desenvolvidas por estas empresas de TIC são do terciário avançado. As entrevistas com os empresários sugeriram que o seu principal cliente é o setor público que se concentra no núcleo da cidade central (Plano Piloto).

Quando perguntados sobre a origem dos recursos financeiros para construção da infraestrutura do Parque Tecnológico Capital Digital, os gestores governamentais alegaram desconhecer os valores pois se tratava de uma outra gestão. Vejamos os trechos das entrevistas:

\section{Como foi em outra gestão não sei informar. ${ }^{115}$}

Como foi em outra gestão não sei informar, mas acredito que tenha sido das próprias empresas que se encontram instaladas lá, a CEB, o Banco do Brasil e a Caixa Econômica. ${ }^{116}$

Os trechos das entrevistas sugerem uma possível falta de continuidade na gestão dos projetos estatais. O Governo do Distrito Federal atual tem preconizado a importância de se consolidar o PTCD e os seus gestores desconhecem os processos anteriores. Essa falta de continuidade pode estar impedindo a implementação do PTCD. Pode-se inferir que existe um discurso institucional que afirma que estão sendo realizadas

\footnotetext{
${ }^{113}$ Entrevista concedida pelo Pesquisador A, em maio de 2016.

${ }^{114}$ Entrevista concedida pelo Pesquisador A, em maio de 2016.

${ }^{115}$ Entrevista concedida pelo Gestor C, em abril de 2016.

${ }^{116}$ Entrevista concedida pelo Gestor A, em maio de 2016
} 
ações para a implementação do parque, mas a realidade parece se apresentar de forma diferente.

Quando foi perguntado sobre a implantação do Parque Tecnológico Capital Digital e quem são os atores envolvidos no processo, os entrevistados responderam o seguinte, conforme trechos abaixo:

\section{Pesquisador:}

Os envolvidos na implantação do PTCD são os empresários, o governo e os centros de pesquisa. $\mathrm{O}$ problema é que desde a elaboração do seu projeto existem interessantes conflitantes. O PTCD surgiu da necessidade de se desenvolver uma atividade produtiva que se desvinculasse da atividade administrativa que a cidade possui. O projeto foi idealizado com duas empresas âncoras (Datacenters do Banco do Brasil e Caixa) que atendem a demanda do Governo Federal. Então, penso que continua se reproduzindo a função hegemônica dos serviços em Brasília, só que mais sofisticado (terciário avançado). Dessa forma, o parque como está sendo implementado não atinge o pequeno empreendedor, o que em suma, desenvolve as inovações. Não vejo também a interação da empresa empreendedora do parque, a TERRACAP com a academia, a Universidade (UnB). Assim, o parque não avançou ainda porque os interesses dos envolvidos vão se modificando, criando outras prioridades. ${ }^{117}$

Pesquisador:

Não avançou ainda. As empresas lá instaladas, os Datacenters do Banco do Brasil e da Caixa Econômica não produzem TIC, são centros de processamento, armazenamento de dados dos bancos, guardam informações em tecnologia da informação. ${ }^{118}$

Empresário de TIC:

O parque não se consolidou ainda porque faltam incentivos fiscais para que as empresas de TIC se instalem na área. Existe também a falta de incentivos financeiros por parte dos bancos públicos e privados. Alguns de nós já possuímos uma empresa com capital consolidado, uma carteira de clientes, teríamos que arcar somente com os custos operacionais de transferência para o parque tecnológico (PTCD) $)^{119}$

\section{Empresário de TIC:}

Tem o problema agora da mudança de finalidade do parque. O governo quer colocar a Embrapa lá. Ouvi lá no sindicato (SINFOR). Isso é um absurdo. Foram décadas para conseguir uma área exclusiva para a produção de inovações. A delimitação da área do PTCD para nós foi uma vitória. Achávamos que em pouco tempo o parque estaria em condições

\footnotetext{
${ }^{117}$ Entrevista concedida pelo Pesquisador A, em maio de 2016.

${ }^{118}$ Entrevista concedida pelo Pesquisador B, em maio de 2016.

${ }^{119}$ Entrevista concedida pelo Empresário A do setor de TIC, em abril de 2016.
} 
de nos receber (empresas de TIC). Era para ser (o PTCD) uma área exclusiva para as empresas de tecnologia da informação. Vai ficar igual ao Bernardo Sayão, uma desorganização só. ${ }^{120}$

Gestor:

Os Datacenters aqui já estão funcionando. Não tem ainda empresas de TI menores (microempresas), mas com a chegada da EMBRAPA pode melhorar isso. A presença dela aqui iria atrair uma série de outras empresas da área de biotecnologia. E tem também o prédio do Datacenter do BRB que vai começar a ser construído. ${ }^{121}$

Gestor:

Como havia dito antes, existe uma necessidade de investimentos maciços para dar condições de instalação para empresas de TIC de porte médio ou pequeno no parque. Estamos buscando parcerias (PPPs) para criar estas condições que são infraestrutura, prédios para a instalação dessas empresas. Estamos buscando investimentos de recursos externos. Existe ainda uma discussão sobre a mudança de destinação das atividades de inovação no PTCD. Mas esta discussão não procede. Existe uma orientação multifuncional em relação ao parque prevista no PDOT (2012) privilegiando duas áreas de pesquisa, a biotecnologia e a informática. Mas essas mudanças têm provocado a resistência do empresariado de TIC local. As negociações com a EMBRAPA estão avançando. Inserir o setor de biotecnologia no PTCD não considero um desvirtuamento de seu projeto inicial. Entendo que existe um mercado considerável de TIC em Brasília, com várias empresas atuando nele, mas que não se organiza, não propõe parcerias para o PTCD que está parado a mais de seis anos ${ }^{122}$. E a EMBRAPA tem dinheiro para investir no PTCD. ${ }^{123}$

Estas falas acima contribuem para o entendimento da questão de pesquisa. As intencionalidades dos atores envolvidos nas entrevistas sugerem algumas considerações sobre a implementação do Parque Tecnológico Capital Digital.

Para os representantes dos pesquisadores nas entrevistas os interesses conflitantes entre os atores envolvidos podem estar impedindo os avanços na implantação do parque. Consideram ainda, que as empresas âncoras nele instaladas não produzem TIC. Como se tratam de grandes empresas (Banco do Brasil e CEF) estas não necessariamente estabeleceriam relações diretas com as atividades inovadoras que se instalassem no parque. Pois como atuam no parque como centro de dados não demandariam, via de regra, por inovações de empresas menores que venham a se instalarem.

\footnotetext{
${ }^{120}$ Entrevista concedida pelo Empresário B do setor de TIC, em abril de 2016.

${ }^{121}$ Entrevista concedida pelo Gestor B (Datacenter), em abril de 2016.

${ }^{122}$ Se refere ao registro do imóvel pela TERRACAP em 2009, conforme informação no Quadro 6.4.

${ }^{123}$ Entrevista concedida pelo Gestor C, em abril de 2016.
} 
Para os representantes dos empresários de TIC nas entrevistas o PTCD não avançou ainda, devido à falta de incentivos fiscais e financeiros para as empresas de TIC se instalarem no PTCD, sendo estes incentivos o principal fator decisivo para a localização das empresas no parque tecnológico. Alegam que as mudanças de finalidade do parque é um retrocesso. O parque abrigará também, segundo o PDOT (2012) atividades de biotecnologia com a presença da Empresa Brasileira de Pesquisa Agropecuária EMBRAPA. Na visão destes empresários de TIC, isso representaria um desvirtuamento da finalidade do parque que é a produção de inovações em tecnologia da informação e comunicação. Outra interferência é que esta mudança de finalidade poderá levar o PTCD a mesma situação que o Setor Industrial Bernardo Sayão como mostramos no tópico $6.1 \mathrm{em}$ que houve quase total desvirtuamento de sua proposta inicialmente prevista com a presença de atividades diversas na sua área ${ }^{124}$.

Para os gestores representantes do Governo o parque não avançou ainda porque existe uma necessidade de investimentos para criar condições das empresas de TIC de porte médio ou micro e pequenas empresas no parque. Segundo estes, a busca por parcerias público privadas pode ser uma alternativa ao desenvolvimento do parque. Ainda, as mudanças trazidas pelo PDOT (2012) sobre as atividades a serem desenvolvidas na área do parque tem provocado a resistência dos outros segmentos, especialmente os empresários de TI locais.

Podemos inferir diante destas visões que a implantação do Parque Tecnológico Capital Digital tem avançado pouco por causa dos interesses conflitantes dos atores envolvidos. Existe uma possível tendência por parte do seguimento Governo em manter a importância imobiliária da área do parque o que afastaria a maioria dos médios e micro e pequenos empresários interessados devido aos altos custos de instalação gerados pela valorização do empreendimento ${ }^{125}$.

As visões dos moradores da comunidade local da Vila Weslian sugerem ainda um distanciamento destes atores em relação ao PTCD. Nos trechos das falas das entrevistas com estes moradores inferimos que desconhecem membro da comunidade local que trabalhe no parque tecnológico. Ao meu ver, este distanciamento da comunidade local pode contribuir para o acirramento das desigualdades socioespaciais e ao mesmo tempo

\footnotetext{
124 Ver Fotos 6.2 e 6.3 no tópico 6.1.

$125 \mathrm{O}$ empreendimento demanda um investimento considerável uma vez que será um único prédio no PTCD que abrigará estas empresas.
} 
poderá produzir um "enclave" de desenvolvimento econômico inserido no contexto de um entorno imediato com realidade diferente.

Por outro lado, inferimos das entrevistas com os moradores da comunidade local as visões destes em relação a possíveis danos ambientais causados pela presença do parque em seu entorno imediato ou da interferência do mesmo em seus cotidianos. Como forma espacial da acumulação flexível o parque tecnológico apesar de ser considerado uma indústria limpa pode provocar algum dano no território usado, mas de proporção menor se comparados com outras formas produtivas como a indústria pesada de transformação.

Tratamos até aqui de um território usado apropriado pelas ações humanas. Para falar das questões ambientais deveríamos retornar ao espaço, categoria geográfica anterior ao território e que reflete a natureza e o meio natural. Todavia, vivemos a hegemonia da acumulação flexível e o do meio técnico-científico marcado pelas intencionalidades que se manifestam no território usado.

É justamente nestas intencionalidades que se sustentam as interferências no meio natural. Elas indicam que existem uma cientifização e uma tecnificação da paisagem. $\mathrm{O}$ meio natural ${ }^{126}$ deixou de ser uma parte significativa do nosso meio ambiente com o advento da técnica. A crise ambiental surge num momento em que a dinâmica da acumulação flexível impõe constante adaptação das formas e normas ao seu regime.

As formas geográficas ${ }^{127}$ são adaptadas às necessidades do mercado. O Parque Tecnológico Capital Digital, forma da acumulação flexível e não diferentes das de outras formas geográficas pode estar contribuindo para a vulnerabilidade ambiental ${ }^{128}$ no território usado. O PTCD conforme apresentado no início deste capítulo está localizado às margens da rodovia EPIA Norte (DF -003) e em área contígua ao Parque Nacional de Brasília.

O Parque Tecnológico Capital Digital de Brasília está localizado nas proximidades de um ecossistema que apresenta fragilidade ambiental, na bacia hidrográfica do lago Paranoá. Observa-se que um dos maiores problemas apresentados pelo território usado de Brasília é justamente a preservação dos mananciais hídricos e a garantia de um abastecimento de água a toda a população do Distrito Federal.

A Figura 6.15 mostra o limite atual do Parque Nacional de Brasília e a questão fundiária da área e a localização do PTCD numa área de fragilidade ambiental (entorno imediato de uma unidade de conservação federal) pode apontar alguns problemas

\footnotetext{
126 Para Santos (2006, p. 157) aquele sem grandes transformações.

127 Objetos técnicos para otimizar a produção.

${ }^{128}$ Conceito de Milton Santos (2006, p. 157) que afirma que a vulnerabilidade aumenta com o crescimento econômico local.
} 
ambientais. Importante mencionar que não se trata esta discussão de uma elaboração técnica de danos ambientais no território usado do objeto de estudo. Intenciono buscar nas falas dos entrevistados e nas observações do trabalho de campo possíveis situações causadoras ou indicativas que possam estar contribuindo para o quadro de vulnerabilidade no território usado do Parque Tecnológico Capital Digital.

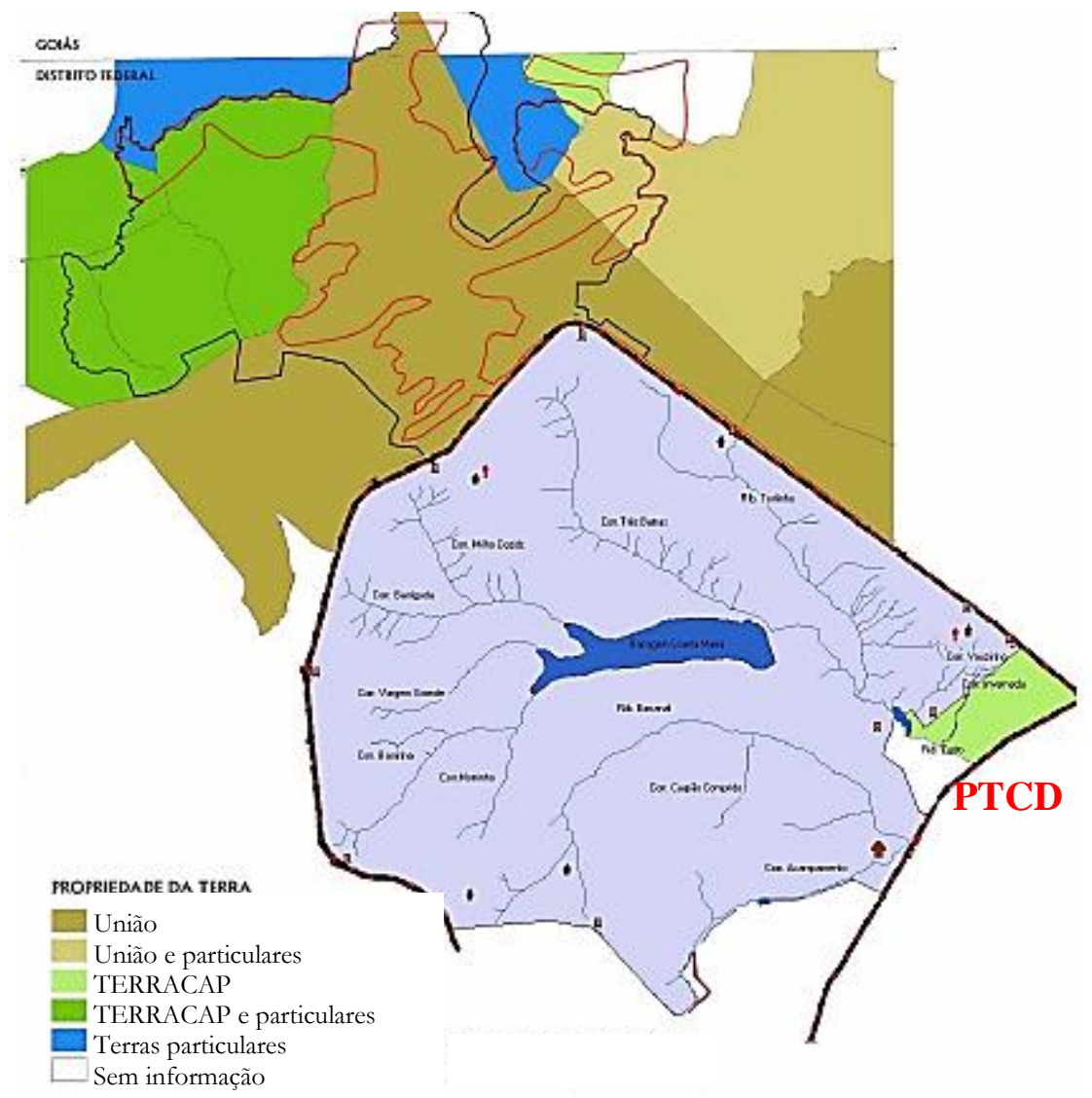

Figura 6.15 Limite atual do PARNA e a questão fundiária da área

Mostra o limite atual do Parque Nacional de Brasília (marcado na cor preta), a questão fundiária da área e a localização do PTCD numa área de fragilidade ambiental.

Fonte: TERRACAP (2004).

O agravamento dos danos ambientais provenientes da construção/ funcionamento do Parque Tecnológico Capital Digital - PTCD pode interferir nos mananciais hídricos da área. O PTCD está situado entre dois importantes contribuintes do Lago Paranoá, os ribeirões do Torto e Bananal. Existe ainda, um ponto de captação de águas superficiais da Caesb próximo ao parque, o ponto de captação de água do Torto. A 
presença destes mananciais indica a possível fragilidade hídrica da área em que se encontra o PTCD. Vejamos trechos da entrevista com um morador da comunidade local:

(...) quando começaram a obra tamparam tudo com os madeirites. Mas tinha umas árvores aí e mato aí sim. Perto do prédio novo ${ }^{129}$ tinha um lugar que de saia água, tipo uma nascente. Costumava ir lá com meu cachorro. Mas aí eles tamparam tudo e fizeram o estacionamento no local. ${ }^{130}$

A retirada da cobertura vegetal pode interferir nos mananciais hídricos da área. A fala do morador sugere que houve a retirada da vegetação e a pavimentação em área de afloramento hídrico. Desta situação podemos inferir uma possível despreocupação do empreendedor do parque com a recuperação e preservação dos locais de afloramento do lençol freático prevista na legislação vigente ${ }^{131}$. O abastecimento de água no Distrito Federal é um dos problemas mais críticos com afirmamos anteriormente e a área do parque está nas proximidades de um ponto de captação de água. ${ }^{132}$

A retirada da cobertura vegetal é também um dano ambiental. Peluso; Cidade (2014, p.08) analisando dados de pesquisa da Unesco (2002) informam que em 1954, a participação do bioma cerrado no Distrito Federal era de 37,84\%, em 1994, de 17,29\% diminuindo para 9,81\% em 2001. Estes dados demonstram o avanço do processo de adensamento populacional e urbanização no Distrito Federal e a consequente diminuição do bioma cerrado no seu território usado.

A retirada da cobertura vegetal provoca interferência também no solo. De acordo com Oliveira (1994) a erosão acelerada causada pela atividade humana pode ser laminar ou em lençol quando causada por escoamento difuso das águas das chuvas, resultando na remoção progressiva dos horizontes superficiais do solo.

A área do Parque Tecnológico Capital Digital pode apresentar problemas de drenagem das águas pluviais. Ao longo das vias de acesso a parque observou-se em trabalho de campo a inexistência de caixas de capitação para a coleta destas águas. Vejamos o trecho de entrevista com um morador da comunidade local:

Eles limparam tudo aí, passaram o trator e tinha árvores aí também igual aquele lado de lá ${ }^{133}$. Depois cercou tudo e não vi mais. Na época da chuva

\footnotetext{
${ }^{129}$ Se refere ao prédio da governança em construção.

${ }^{130}$ Entrevista concedida pelo Morador B, da Vila Weslian Roriz, em abril de 2016.

131 A Lei no 6.938/81 prevê o dano ambiental e determina a responsabilidade objetiva do causador do dano.

132 Peluso; Cidade (2014, p. 08) afirmam que os recursos naturais do Distrito Federal estão em risco.

133 Se refere ao outro lado da área do parque, onde não há construções ainda.
} 
a enxurrada na pista aí em frente é bem grande. Antes (da construção do parque) não tinha isso aqui. ${ }^{134}$

Do trecho da entrevista do morador infere-se a situação vulnerável do solo na área. O próprio memorial descritivo do parque (documento técnico) aponta a inexistência de rede de águas pluviais na área, mencionando apenas sobre possível ligação da rede de drenagem do parque com a rede de drenagem do Torto que também não foi implementada. A Foto 6.7 mostra umas das saídas de drenagem de águas pluviais do parque que originam as enxurradas nas vias de acesso.

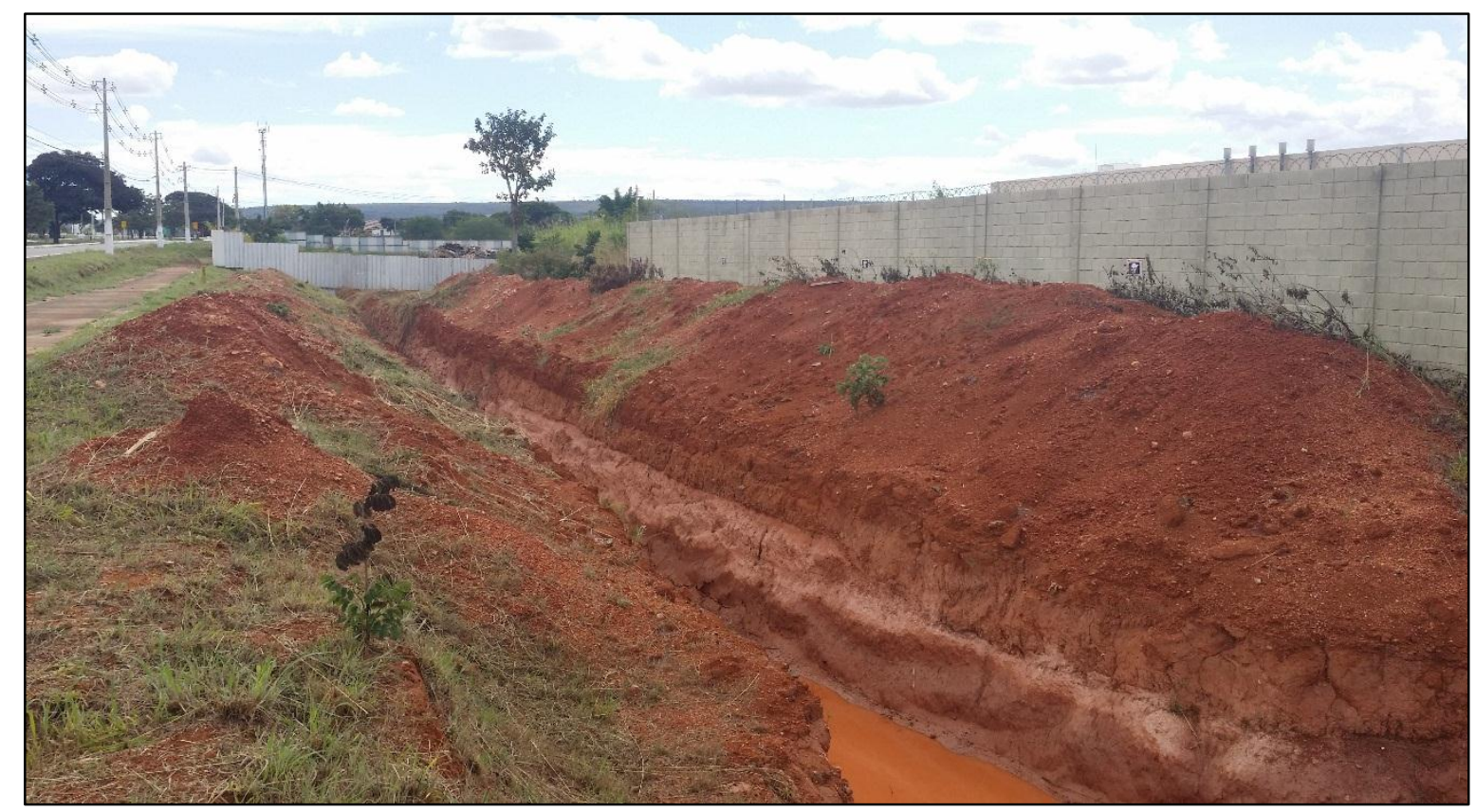

Foto 6.7 Saída da rede de drenagem do PTCD às margens da via de acesso secundário

Mostra a saída da rede de drenagem as margens da via de acesso secundário em frente à Vila Weslian Roriz (canto superior esquerdo).

Fonte: Arquivo do autor (2016).

As águas pluviais do parque provocam enxurradas conforme podemos inferir do trecho da entrevista acima do morador local. Estas águas descem de forma descontrolada em direção ao Ribeirão Bananal o que pode estar provocando o assoreamento do seu leito devido às descargas de materiais sedimentados levados junto com as águas pluviais. Ao longo prazo esta situação pode diminuir a capacidade hídrica deste importante contribuinte do Lago Paranoá. A Foto 6.8 mostra a área de contenção da

${ }^{134}$ Entrevista concedida pelo Morador A, da Vila Weslian Roriz, em abril de 2016. 
rede de drenagem do parque que na época de chuvas transborda e corre pela via de acesso secundário em direção ao Ribeirão Bananal.

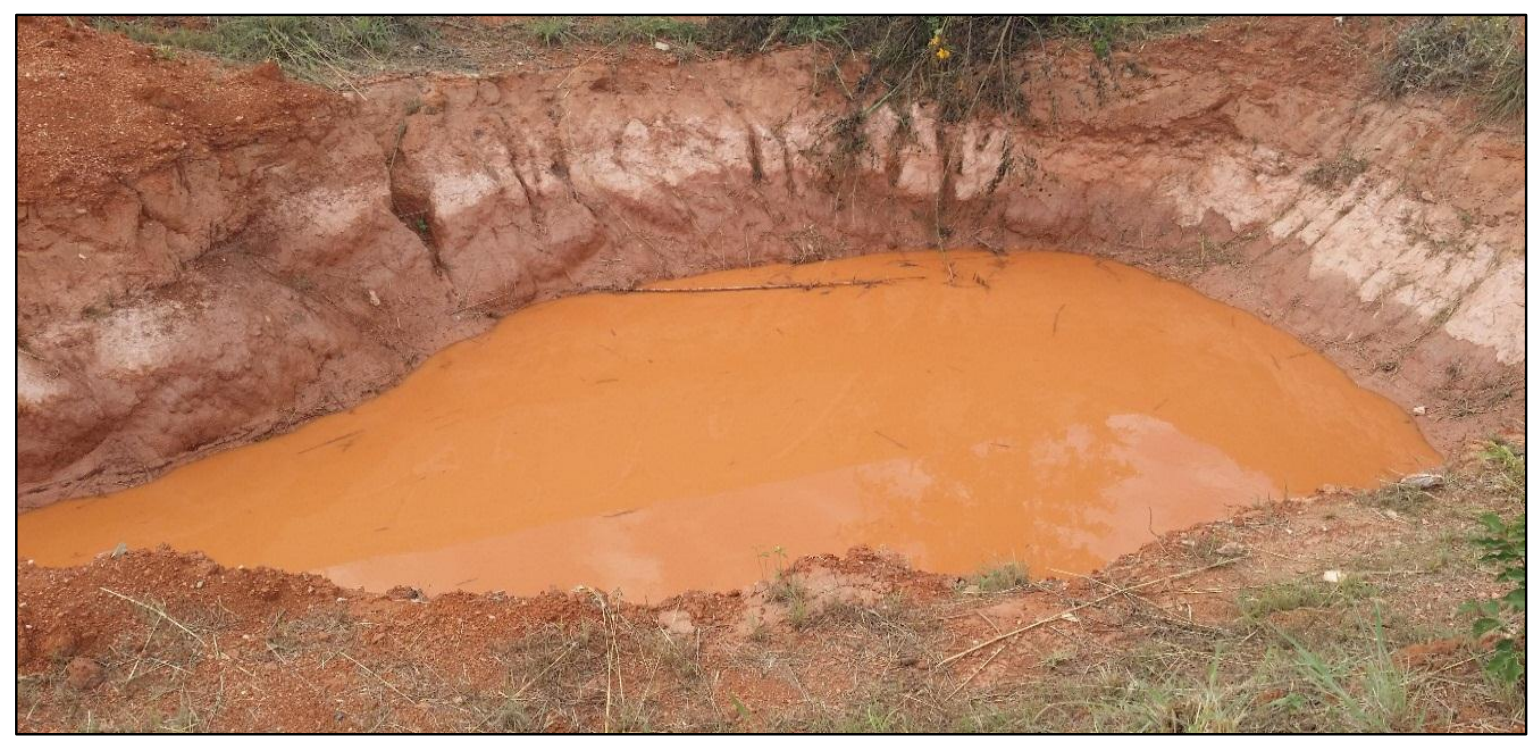

Foto 6.8 Área de contenção da rede de drenagem do PTCD

Mostra área de contenção da rede de drenagem do PTCD que durante o periodo de chuvas transborda invadindo a via de acesso secundário em frente à Vila Weslian Roriz. correndo em direção ao Ribeirão Bananal.

Fonte: Arquivo do autor (2016).

Importante mencionar que o documento técnico emitido pelo IBRAM-DF, licença de instalação $n^{\circ}$ 021/2012 obriga a empresa TERRACAP a monitorar o sistema de drenagem pluvial com o intuito de detectar e prevenir a ocorrência de assoreamento e poluição no Lago Paranoá e no Ribeirão Bananal. A Foto 6.9 mostra a vala para receber a drenagem do PTCD ao longo do muro da subestação da CEB. 


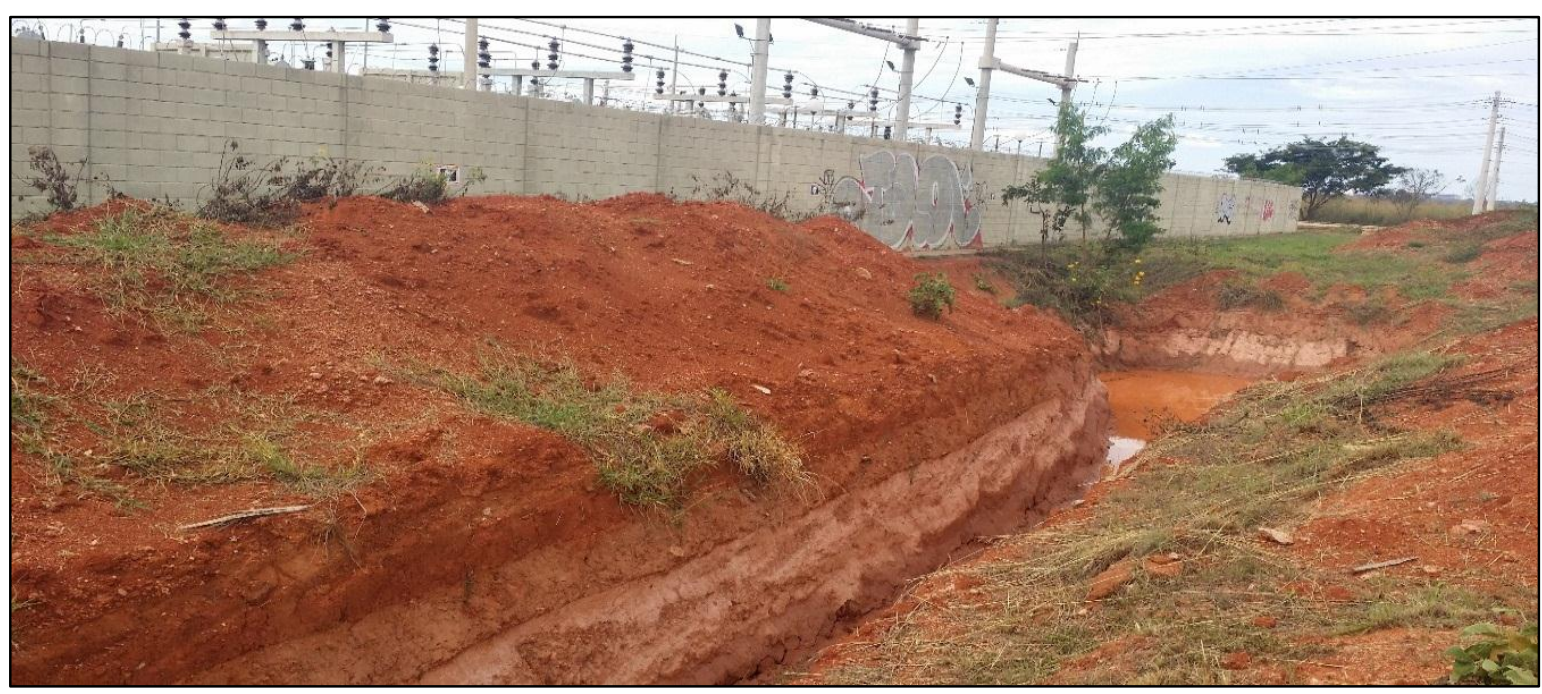

Foto 6.9 Vala recebedora da drenagem pluvial do PTCD

Mostra vala recebedora da drenagem ao longo do muro da subestação da CEB. Observa-se ainda que como não há impermeabilização das laterais da vala, todos esses sedimentos são transportados com a água na época da chuva em direção ao Ribeirão Bananal.

Fonte: Arquivo do autor (2016).

Outra questão observada na construção do parque e já verificada em outras áreas $^{135}$ é a retirada de areia e cascalho para a construção civil. Na área do PTCD existe uma cascalheira. Em visita ao campo verificou-se a existência de uma enorme área de retirada de areia e cascalho conforme se observa nas Fotos 6.10 e 6.11. Nas fotos se observa uma grande área que teve o solo removido e a presença de grandes quantidades de areias que são carregadas pelos caminhões para a construção no parque.

135 Por exemplo a cascalheira do Areal do Canil situada entre o Parque Nacional de Brasília e o Parque Burle Max no setor Noroeste. 

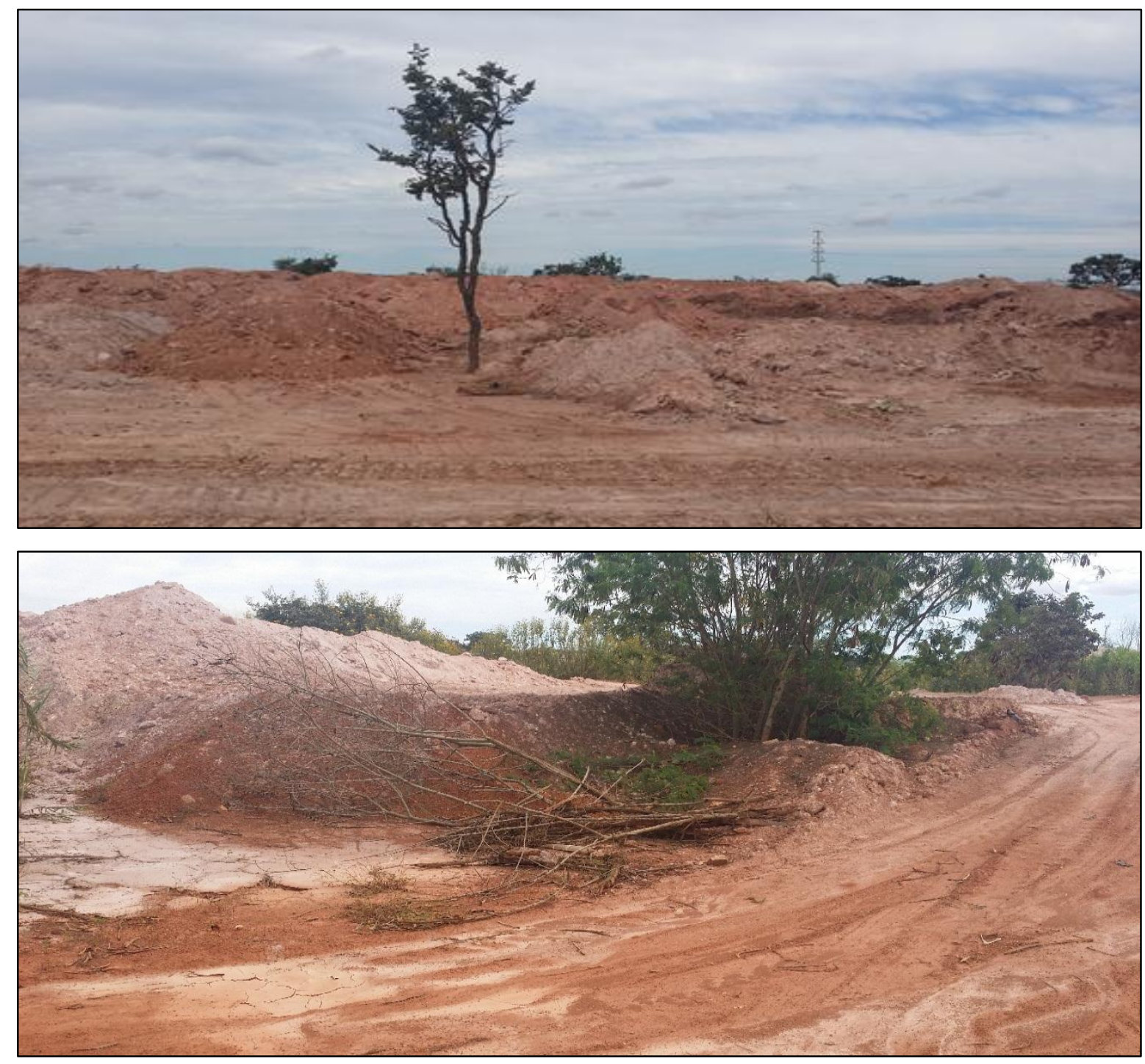

Fotos 6.10 e 6.11: Área de cascalheira no PTCD

Mostram uma grande área de cascalheira dentro do parque tecnológico. A licença de instalação emitida pelo IBAMA exigiu que $57 \%$ da vegetação do parque fosse mantida. Essas áreas acima nas fotos são apontadas no Memorial Descritivo do parque como sem edificaçôes. A foto acima (6.11) mostra a entrada para passagem dos caminhões.

Fonte: Arquivo do autor (2016).

Observou-se que a área degradada encontra-se cercada de vegetação nativa às margens das vias de acesso ao parque. Só é possível a visualização da cascalheira adentrando por um caminho aberto pelo fluxo constante de caminhões em frente à subestação da CEB. As Fotos 6.12 e 6.13 mostram o acesso para os caminhões a área da cascalheira. A Foto 6.13 mostra os caminhões parados na lateral do PTCD em frente ao lote do prédio da governança em construção. 

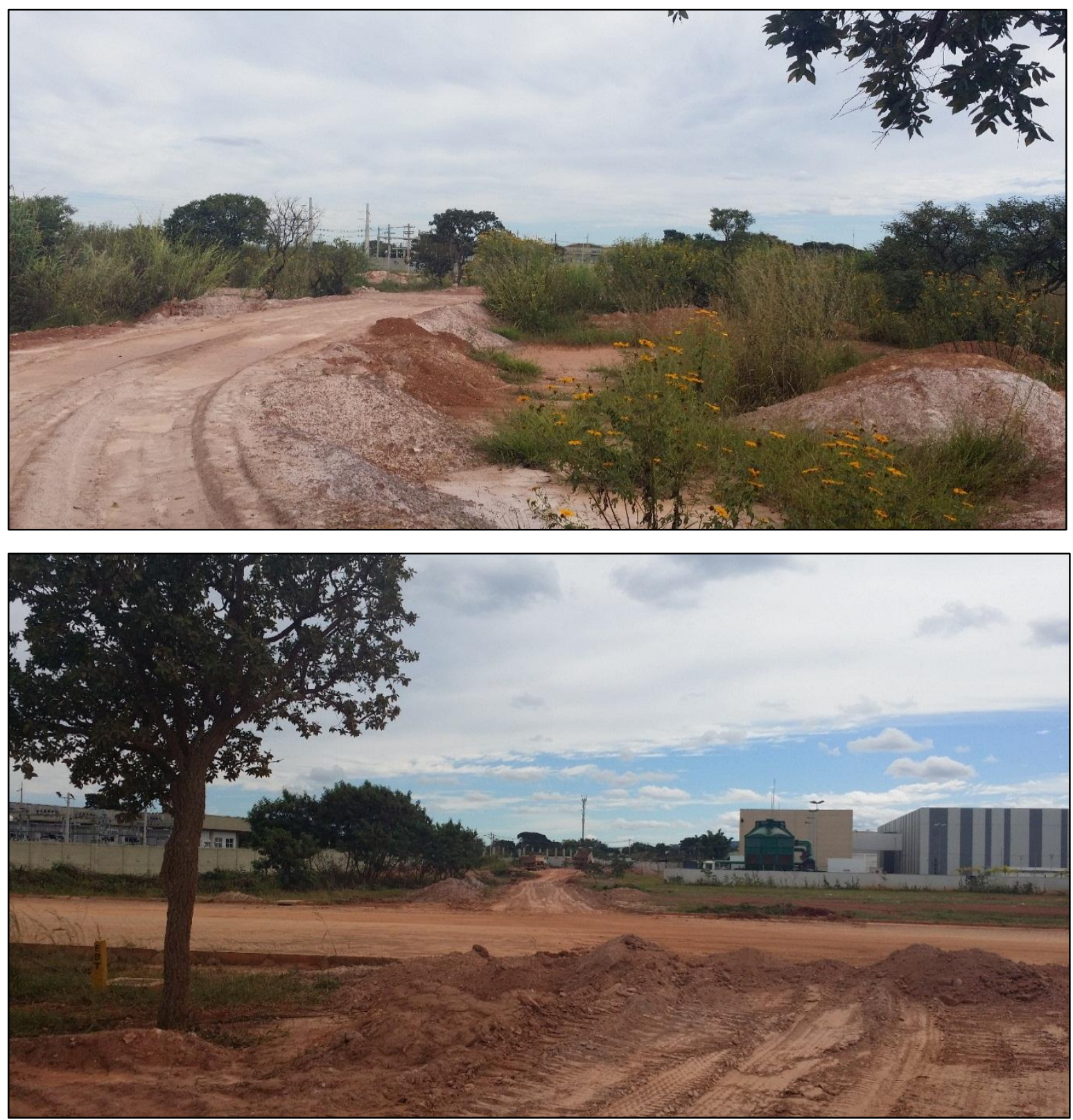

Fotos 6.12 e 6.13 Acesso a área da cascalheira no PTCD

Mostram o acesso para os caminhões na área da cascalheira em frente a subestação da CEB. A Foto 6.12 mostra a entrada da cascalbeira em direção ao parque com estrada para a passagem dos caminhöes à direita da subestação da CEB. Na Foto acima (6.13) é possivel visualizar ao centro os caminhöes parados em frente ao lote da construção da sede da governança.

Fonte: Arquivo do autor (2016).

$\mathrm{Na}$ cascalheira observou-se além dessa situação, a retirada da cobertura vegetal, expondo o solo. Verificou-se a existência de ravinas e sulcos (ver Foto 6.14 abaixo) propícios a produção de voçorocas tendo em vista a perceptível inclinação do terreno ${ }^{136}$. Esta situação pode vir a causar também o assoreamento do Ribeirão do Bananal. O documento técnico (Memorial Descritivo do Parque Tecnológico Capital Digital - 2009)

${ }^{136}$ Existe uma declividade acentuada devido ser área de contribuição do Ribeirão do Bananal. 
constante na licença de instalação do parque informa que o material utilizado para o aterro (areia e cascalho) obrigatoriamente seriam de outra área com licença válida de exploração de jazidas. A Foto 6.15 mostra a retirada de cobertura vegetal na área da cascalheira expondo o solo.
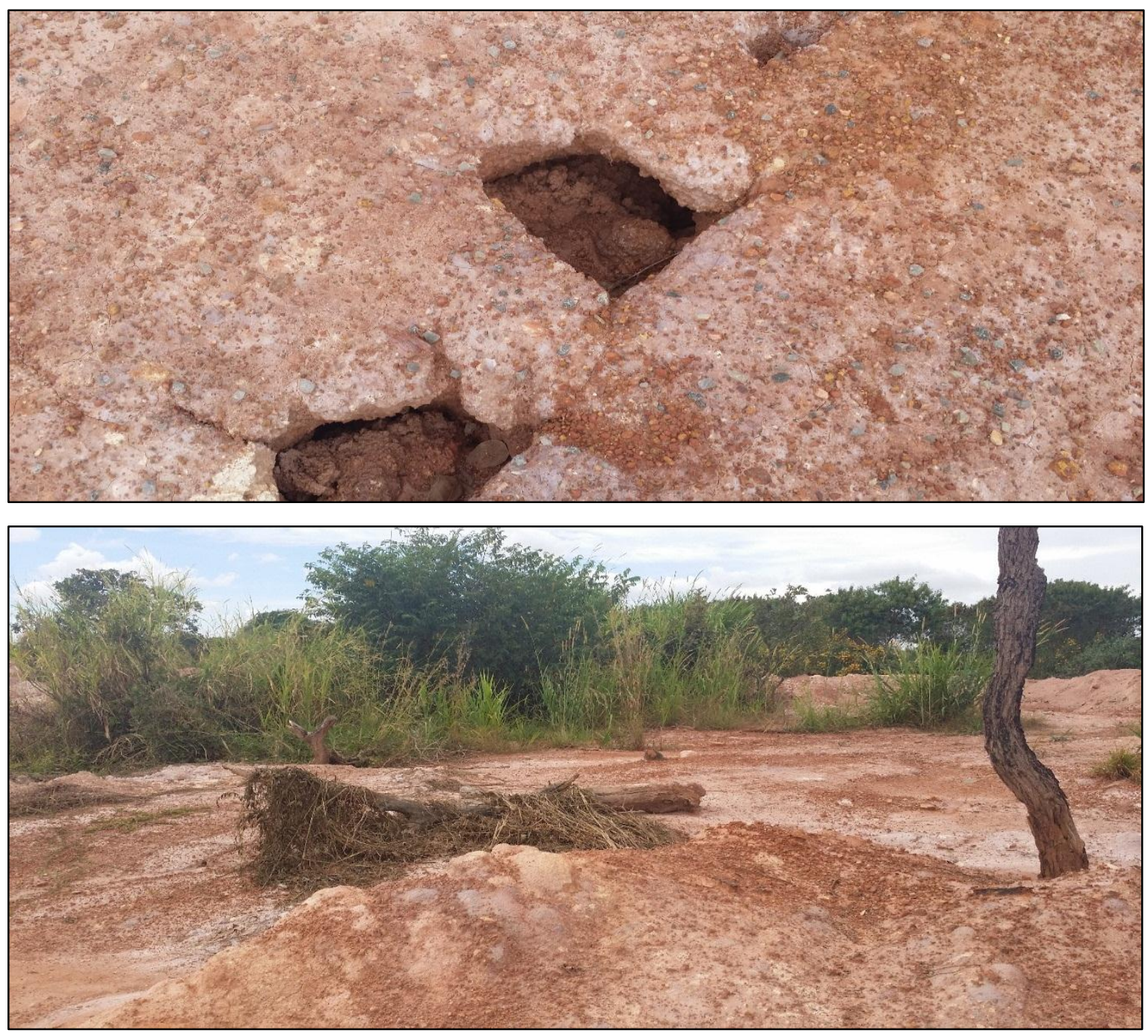

Fotos 6.14 e 6.15 Processo erosivo e retirada da cobertura vegetal na cascalheira

A Foto 6.14 mostra a presença de ravinas/sulcos no solo da área da cascalheira no PTCD que podem originar processo erosivos. Na Foto 6.15, a retirada da cobertura vegetal e a consequente exposição do solo da área. Fonte: Arquivo do autor (2016).

No entanto, a realidade mostra conforme as Fotos 6.16 e 6.17 que tais medidas legais impostas na licença de instalação do parque podem não estar sendo cumpridas. Infere-se diante da realidade apresentada no campo uma distorção do discurso institucional que "vende" à sociedade brasiliense a ideia de um "parque tecnológico com integração 


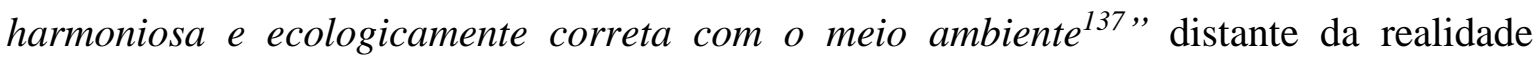
observada.
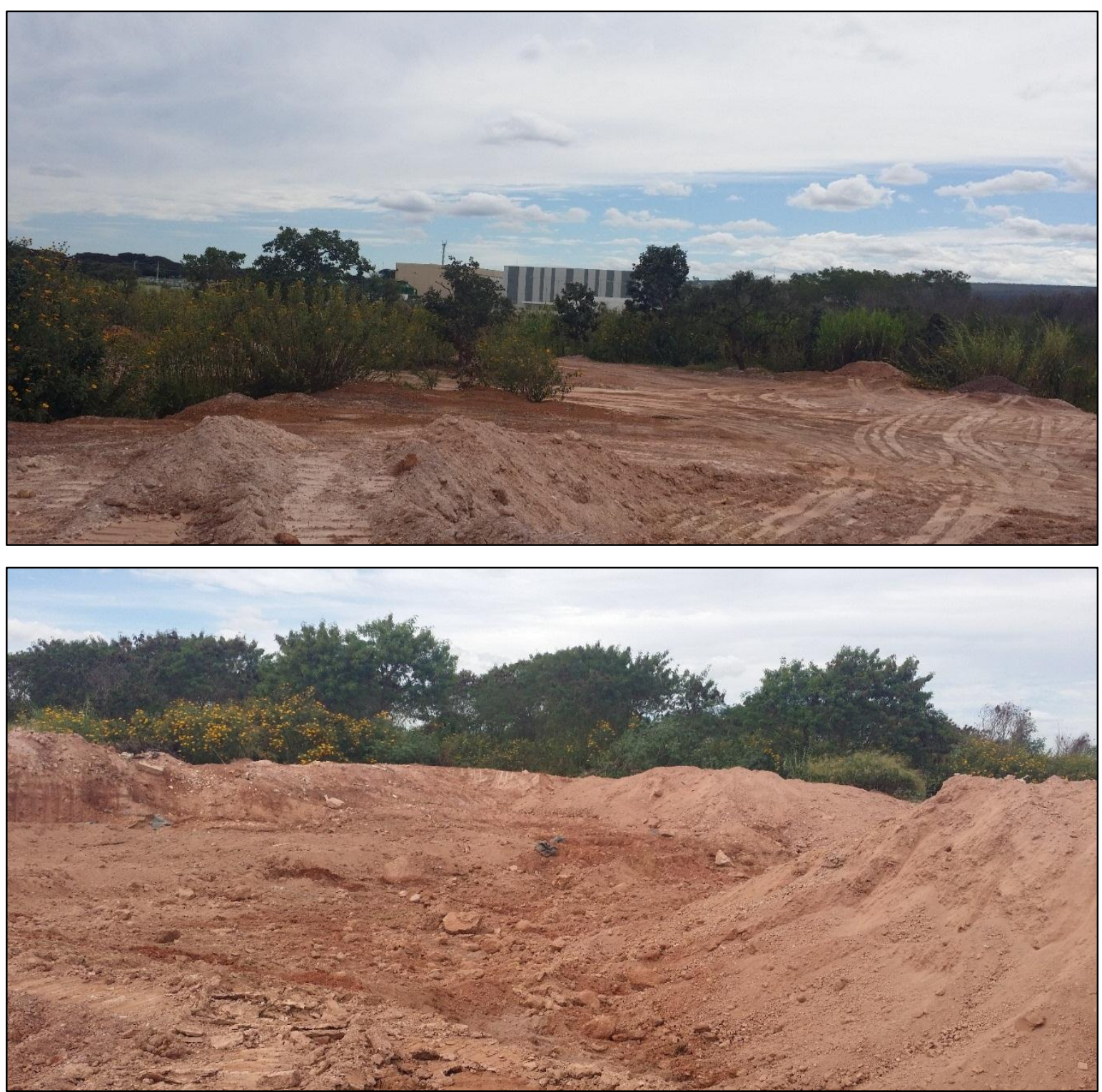

Fotos 6.16 e 6.17 Possíveis danos ambientais do PTCD no território usado

A Foto 6.16 mostra a área da cascalheira com destaque das marcas no solo deixadas pelo intenso fluxo de tratores e caminhões e ao fundo o prédio do Datacenter no PTCD. A Foto 6.17, mostra a enorme área de retirada de cascalho e areia. Em alguns pontos como mostrado na foto acima a retirada chega a dois metros de profundidade.

Fonte: Arquivo do autor (2016).

A Figura 6.15 traz a imagem aérea do Parque Tecnológico Capital Digital antes da construção em abril $2009^{138}$. Observa-se na figura que a área não possuía cascalheira e

${ }^{137}$ Trecho do projeto técnico do PTCD elaborado pela TERRACAP (2008).

138 As obras no Parque Tecnológico Capital Digital tiveram início em novembro de 2009. 
apresentava cobertura vegetal de cerrado em toda a extensão. Dessa forma, pode-se inferir possíveis danos ambientais na área causados pelas construções no parque.

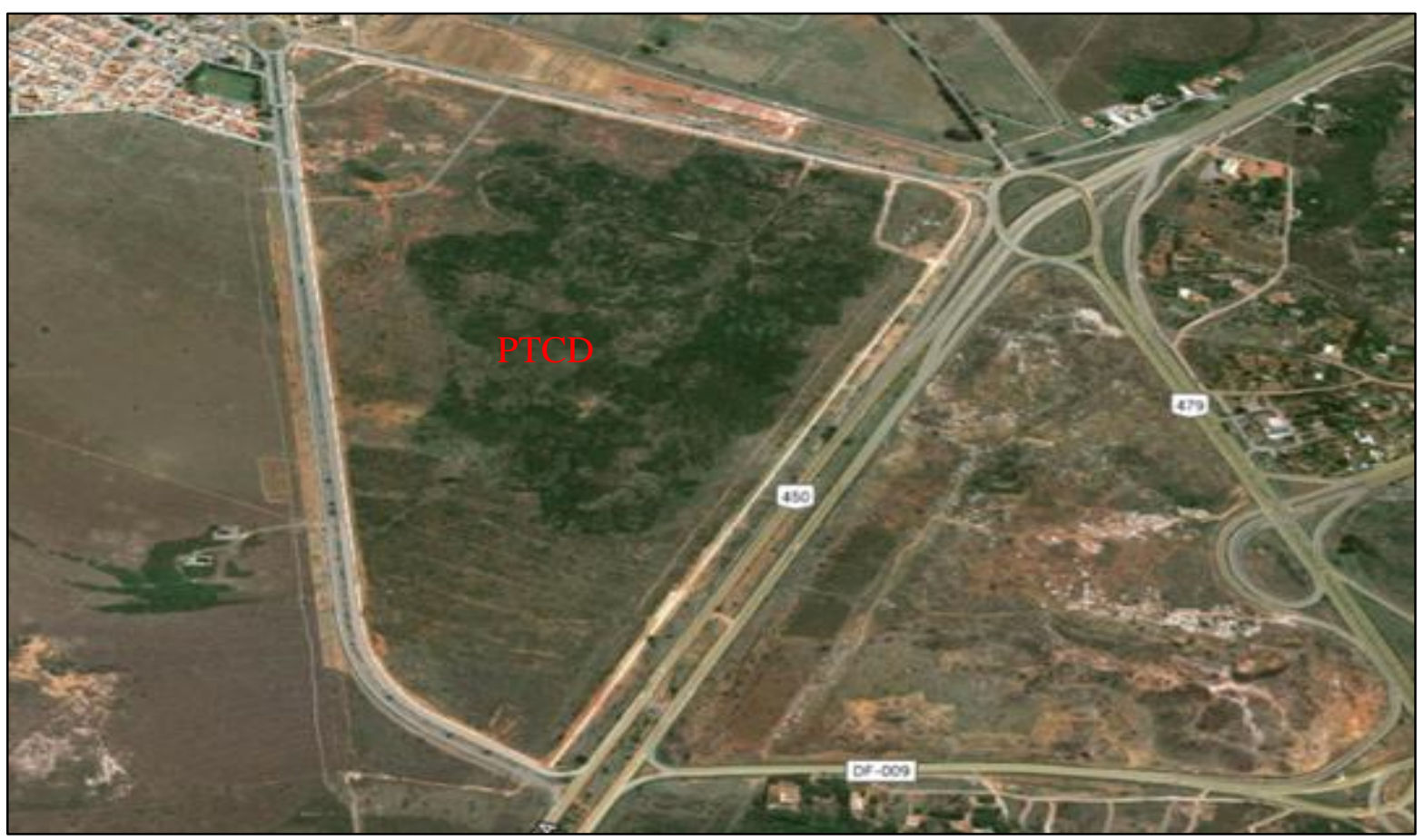

Figura 6.16 Imagem aérea do PTCD antes das obras de edificação

Mostra a área do PTCD antes do início das obras. A figura mostra a inexistência de cascalheira na área e a presença de cobertura vegetal tipica do cerrado em toda a sua extensão.

Fonte: Google Earth (2009).

Outro problema ambiental que pode está acontecendo no Parque Tecnológico Capital Digital é quanto a destinação do entulho e resíduos diversos provenientes da construção. Observou-se que os mesmos estão sendo depositados nas áreas da cascalheira de onde já foram retiradas as camadas de solo e em outras áreas do parque sem retirada. Tal situação pode agravar mais ainda a vulnerabilidade ambiental na área. Os corpos hídricos superficiais e o lençol freático podem ser contaminados com substâncias nocivas destes descartes. A Foto 6.18 mostra uma das áreas do parque tecnológico com resíduos sólidos provenientes de obras de construção civil. 


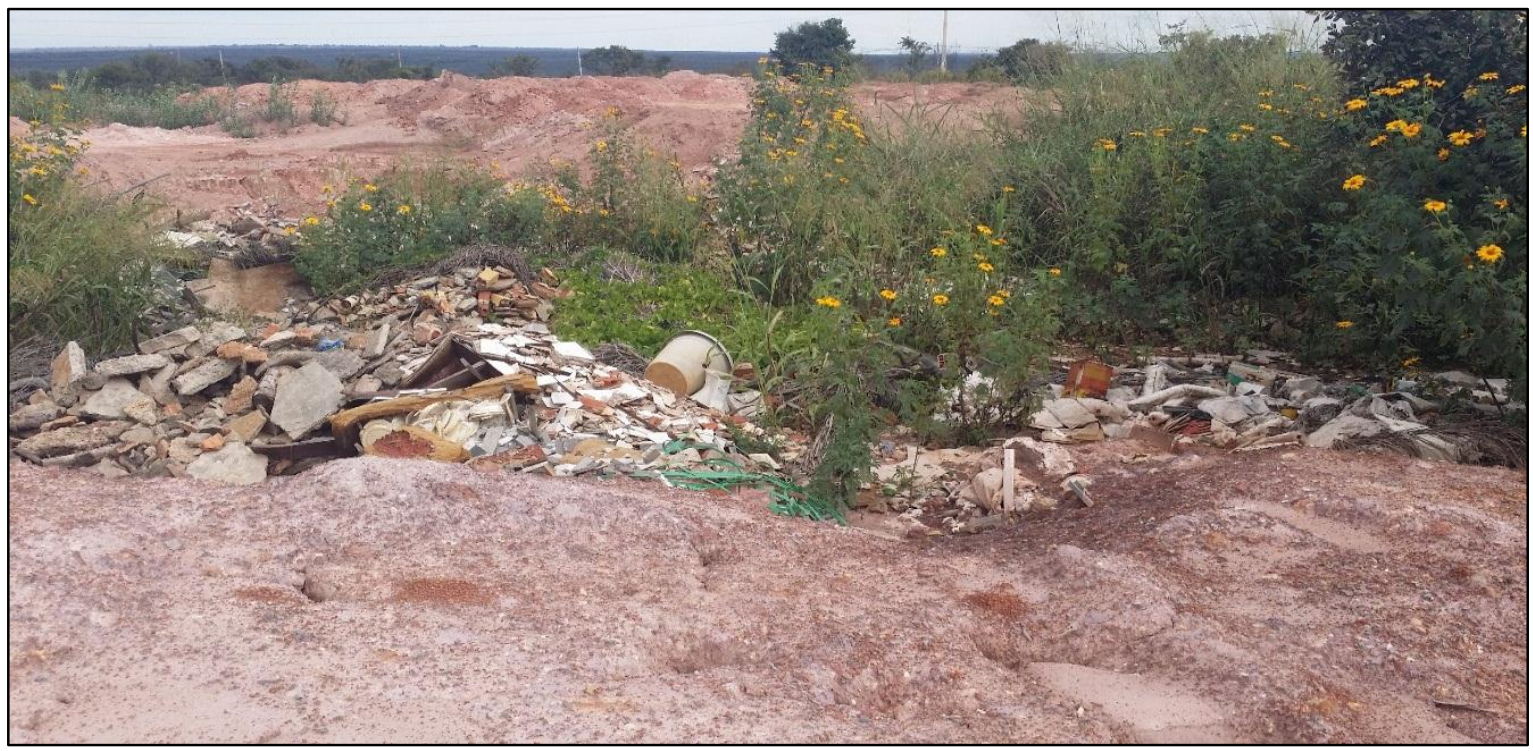

Foto 6.18 Resíduos sólidos de construção na área do PTCD.

Mostra a área com resíduos sólidos de construção na área do PTCD. Foi possivel observar todo tipo de material descartado na área, não biodegradáveis como latas com resto de tinta, isopores e plásticos em geral.

Fonte: Arquivo do autor (2016).

A Foto 6.19 mostra o despejo de resíduos sólidos de construção na área. Mais uma vez, existe uma possível desconexão entre o previsto na legislação e a realidade. No documento técnico já mencionado estes resíduos deveriam ser acondicionados e retirados da área do parque para local adequado. Esta situação sugere um processo de contaminação do solo e dos corpos hídricos em curso na área do parque.

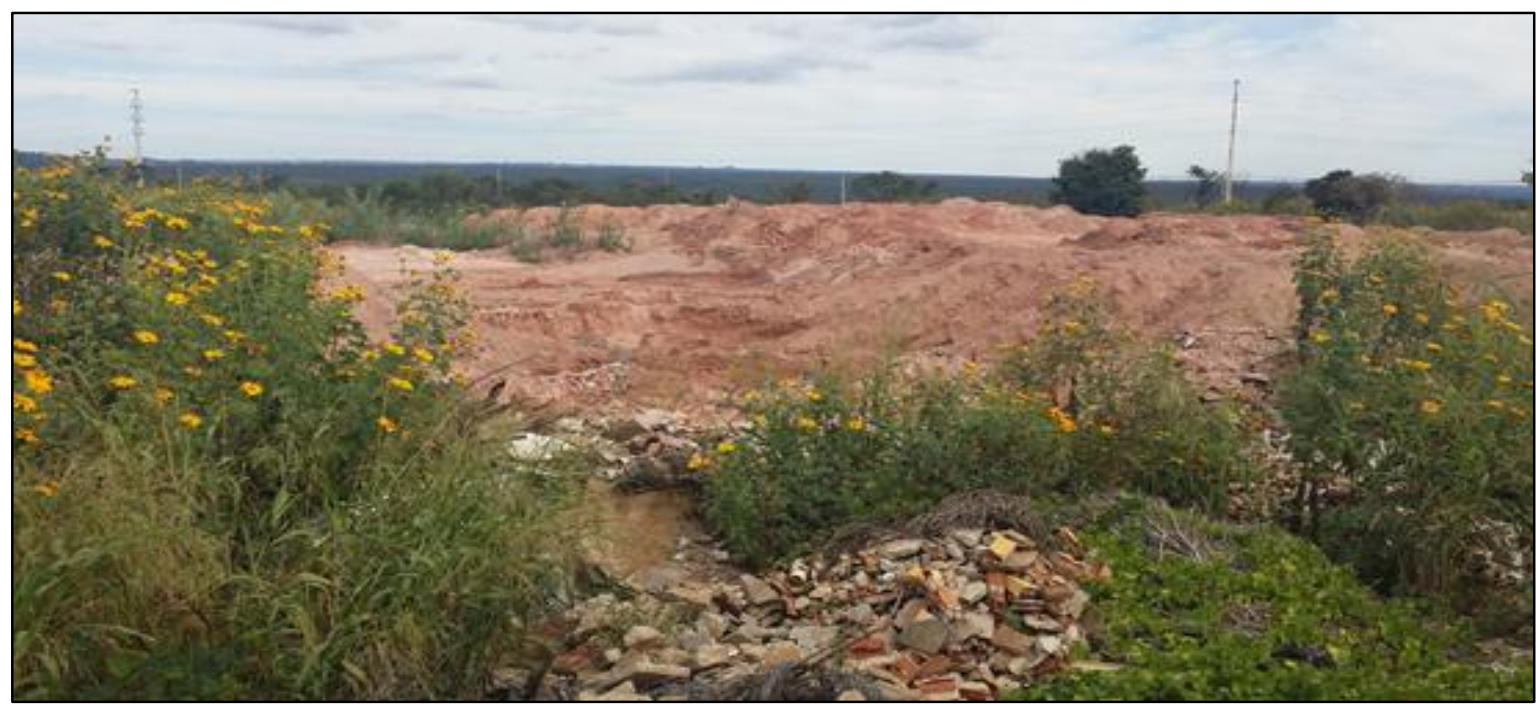

Fotos 6.19 Área de descarte de restos de materiais de construção no PTCD

Mostra uma das áreas de descarte de restos de materiais de construção no PTCD. Observou-se ainda na áreas residuos de material betuminoso derramados em várias partes da área, material este extremamente nocivo ao meio ambiente.

Fonte: Arquivo do autor (2016). 
Não menos importante que os demais problemas para caracterizar a vulnerabilidade ambiental com a implementação do parque é a poluição sonora. Durante a realização dos trabalhos em campo foi possível ouvir barulhos e ruídos consideráveis ${ }^{139}$ provenientes das obras de construção no parque. Essa situação causa impacto negativo à comunidade local que está bastante próxima das instalações do parque. Quando perguntados se a presença do parque interferia nos seus cotidianos os moradores responderam conforme trechos abaixo:

Não alterou. Às vezes o barulho das obras incomoda um pouco, mas é só isso, não tem movimento aí. ${ }^{140}$

Não mudou nada. Só o barulho das obras que incomoda muito. ${ }^{141}$

A poluição sonora é um dos problemas ambientais do meio urbano ${ }^{142}$ que gera consequências negativas na qualidade de vida dos cidadãos. Os trechos das falas dos entrevistados acima mostram o incômodo causado pelas obras do parque que deveriam estar sendo monitoradas e controladas pelos responsáveis do empreendimento. Importante considerar ainda, que o PTCD se encontra em área frágil ambientalmente pela proximidade com a unidade de conservação federal - o Parque Nacional de Brasília, o que pode provocar danos à fauna da área causados por esta poluição sonora.

Por outro lado, podemos pensar que a localização do Parque Tecnológico Capital Digital pode ter sido uma estratégia do planejamento governamental para impedir os avanços da ocupação desordenada e as pressões dos atores envolvidos para agregar valor a outras áreas do território usado de Brasília. A área do PTCD é uma das poucas áreas remanescentes no entorno imediato da cidade tombada que não sofreu uma ocupação. O ator Governo verificando as pressões e as ocupações desordenadas ao redor do PARNABrasília, como o lixão da estrutural, a cascalheira do canil e a própria Vila Weslian Roriz tratou de assegurar a ocupação da área do Parque Tecnológico Capital Digital de forma planejada e ordenada para conter as problemáticas ambientais já presentes em outras áreas.

139 Não é possível dizer se os decibéis estavam dentro das normas legais fixadas para o tipo de atividade na área, seria necessário aparelho específico para isso, mas ressalto que os ruídos eram incômodos.

${ }^{140}$ Entrevista concedida pelo Morador B, da Vila Weslian Roriz, em abril de 2016.

${ }^{141}$ Entrevista concedida pelo Morador A, da Vila Weslian Roriz, em abril de 2016.

${ }^{142}$ Exemplo disso é a cidade de Águas Claras - RAXX, que durante muito tempo foi considerado o maior canteiro de obras do Distrito Federal impôs aos seus moradores uma constante poluição sonora que diminuía a qualidade de vida na área. 
Todavia, o planejamento governamental para área do Parque Tecnológico Capital Digital como tentamos mostrar aqui não tem sido suficiente para impedir as modificações no projeto pensado para o parque pelos interesses conflitantes dos agentes envolvidos.

Diante desta possível problemática ambiental o Parque Tecnológico Capital Digital acompanha a dinâmica conflituosa que a metrópole brasiliense também enfrenta: conciliar o desenvolvimento econômico, a expansão metropolitana, a conservação de seu ecossistema e os diferentes conflitos de interesses entre os seus atores envolvidos. Peluso; Cidade (2014, p. 10) afirmam que o desafio da problemática ambiental na Brasília metropolitana está na compreensão da interligação de uma expansão urbana que emerge nos interstícios do planejamento e que é, posteriormente incluída em novos planejamentos que, por sua vez, criam novos problemas ambientais e tornam-se objeto de novos conflitos.

Os planos de ordenamento territorial como vimos no Capítulo 5, não conseguiram impedir o uso predatório dos ecossistemas no território usado de Brasília. A problemática ambiental aqui levantada pelas visões dos atores em relação ao Parque Tecnológico Capital Digital parece refletir a mesma dinâmica que acompanha a cidade: ocupação de áreas com fragilidade ambiental a despeito das restrições ambientais de proteção aos recursos naturais, principalmente os hídricos que como vimos nessa discussão estão mais suscetíveis aos efeitos sistêmicos da degradação (retirada da cobertura vegetal, erosão do solo, contaminação do solo, entre outros). Como vimos nas visões dos atores envolvidos estes efeitos parecem ocorrer no Parque Tecnológico Capital Digital.

As visões dos atores suscitam algumas considerações. As falas apresentadas dos gestores sugerem que Governo tem implementado o Parque Tecnológico Capital Digital, seguindo as mais rigorosas recomendações ambientais. Todavia, podemos observar com base nas falas de outros atores envolvidos que a realidade se apresenta de forma bem diferente. A problemática ambiental no Parque Tecnológico Capital Digital está relacionada a outros fatores que vão além do discurso institucional aceito. Numa perspectiva mais crítica sugere-se que a implantação do parque apesar de todo o planejamento envolvido conforme apresentamos no início deste Capítulo não tem levado em consideração outros fatores além daqueles relacionados à valorização imobiliária do empreendimento. As intencionalidades dos atores envolvidos sugerem uma distorção entre o planejamento pensado para o parque e o que se encontra em andamento. 


\section{CONSIDERAÇÕES FINAIS}

Esta tese teve por objetivo analisar o Parque Tecnológico Capital Digital de Brasília enquanto forma de expressão espacial da acumulação flexível no território usado de Brasília. No primeiro momento consideramos que os parques tecnológicos são formas de expressão espacial para atender os interesses hegemônicos da acumulação flexível a partir da tecnosfera. No segundo momento, partimos do entendimento que o processo de implementação dessas formas espaciais é marcado pela interferência das intencionalidades dos atores envolvidos numa apropriação conceitual da psicosfera.

A implementação dos parques tecnológicos obedece uma lógica espaço-tempo no território usado. Assim, consideramos nesta Tese o território usado como uma totalidade concreta compreendida através de eventos. Estes contribuem diretamente para a geografização do nosso objeto de estudo e ao mesmo tempo nos apontam as intencionalidades dos atores em impregnar o território com determinadas funções e/ ou usos.

Com base nestas afirmações enfatizamos nesta análise o território usado que se encontra em permanente transformação segundo o sentido e a essência dos eventos que abarca. A luz destas considerações e sem ter a pretensão de apontar uma conclusão final a partir do exposto até aqui, tentarei sintetizar algumas ideias, antevendo os possíveis desdobramentos para repensar sobre outras questões sucedâneas.

Na perspectiva da tecnosfera

No Capítulo 3, ressaltamos que além dos aspectos socioeconômicos na temática dos parques tecnológicos existem também os aspectos territoriais. A inserção dos parques tecnológicos interfere na organização espacial das cidades. Em um momento de expansão urbana marcado por adensamento e ao mesmo tempo fragmentação do tecido urbano ocupado, os parques tecnológicos têm participado de tal forma a criar ou reorganizar centros de produção que interessam à acumulação flexível. Assim, os parques são utilizados para promover o desenvolvimento econômico, mas podem ser também utilizados como políticas regionais/locais. Podem ser ainda, formas espaciais que visam a renovação da estrutura industrial anterior numa espécie de reparo espacial ou desenvolvimento do setor de serviços avançados no território. 
Ainda neste mesmo Capítulo, as experiências internacionais com parques tecnológicos demonstraram que a acumulação flexível vem interferindo na dinâmica territorial mundial. As empresas instaladas nos parques tecnológicos operam com elevados índices de competitividade e alto conteúdo inovador em áreas que ofereçam vantagens locacionais.

A experiência norte-americana com parques tecnológicos foi desde o princípio um empreendimento de iniciativa privada tendo à frente as grandes corporações. No Japão, as iniciativas com parques tecnológicos foram implementadas pelo Governo que construiu inúmeros centros de pesquisas com base no planejamento. Os parques tecnológicos chineses estiveram voltados para a atração de empresas multinacionais para a promoção de suas indústrias nacionais ao mercado global e consistiram numa tentativa de aumentar a competitividade das indústrias nacionais com a presença de multinacionais. Na Itália, as experiências com parques tecnológicos surgiram como formas espaciais capazes de promover o desenvolvimento econômico.

Como resultado do levantamento destas experiências podemos afirmar que o desenvolvimento de inovações nesses países predomina sob a forma de parques tecnológicos (empresas, centros de pesquisas e universidades) e as áreas onde são implementados eram áreas com estrutura industrial anterior, ou seja, os parques implementados visavam à renovação dessa estrutura. Importante mencionar ainda, que os parques tecnológicos foram utilizados como instrumentos de políticas de desenvolvimento econômico regional/local com a intervenção ou participação do Estado.

Nesta análise enfatizamos que os parques tecnológicos são formas de expressão espacial da acumulação flexível voltados para o desenvolvimento econômico. Em alguns casos apresentados, os parques tecnológicos podem ser considerados como alternativas de revitalização de áreas industriais estagnadas ou como instrumentos de planejamento. Numa perspectiva da tecnosfera, são os fatores decisivos que definem para as empresas inovadoras a escolha da localização.

No Capítulo 4 tentamos estabelecer que o cenário produtivo brasileiro teve como vetor de desenvolvimento a industrialização. Houve um movimento de concentração industrial na região Sudeste do país, transformando o território usado tanto em um instrumento, quanto um produto do regime de acumulação intensiva em um primeiro momento. O desenvolvimentismo promovido pelo Estado reforçou o papel da urbanização como base para a industrialização. Como consequência a urbanização concentrada e o acirramento das desigualdades regionais. $\mathrm{O}$ resultado foi um alto grau de polarização no 
eixo Sul-Sudeste com a consolidação da metrópole concentrada - São Paulo. Por outro lado, esse processo de concentração industrial e a consequente demanda em expansão propiciou também um movimento de integração do território por meio das redes de transportes em que os sistemas rodoviários federal, estadual e municipal foram articulados principalmente no Centro-Sul do país, enquanto rodovias se consolidaram para integração dos eixos norte e sul.

Ressaltamos neste Capítulo que as ações de gestão no território usado brasileiro procuraram conciliar estabilização econômica e desenvolvimento econômico fazendo surgir um projeto geopolítico de ordenamento territorial nacional com o objetivo de modernizar e expandir a economia nacional articulando-a com o cenário internacional. Estas ações estiveram expressas principalmente nos planos nacionais de desenvolvimento e estenderam o controle do Estado a todas as atividades e a todo o território nacional.

Mostramos que este processo que esteve presente em todas as fases analisadas evidenciou o processo de integração do território como um recurso simbólico para a legitimação do Estado. As políticas estabelecidas privilegiaram o crescimento industrial sustentado pela urbanização intensa e permanente. A urbanização do território usado tornou-se uma estratégia para o desenvolvimento do país.

Neste contexto, a cidade de São Paulo destacou-se como o centro de gestão e acumulação de capital e o núcleo de comando de uma vasta rede urbana que se conectou a multiplicidade de espaços e tempos que compõem o território usado. A expansão territorial pela urbanização foi vista em relação à região Nordeste, na configuração de uma imensa fronteira e na confirmação de um vasto complexo urbano-industrial a partir do centro dinâmico do Sudeste.

A cidade de São Paulo continuou a estender sua centralidade urbana, reafirmando seu papel de metrópole concentrada. Assim, a região Sudeste com sua metrópole manteve a área core e o núcleo polarizador aumentando as disparidades regionais no território usado brasileiro, resultando em um movimento de reconcentração das atividades produtivas nas regiões Sul e Sudeste. E foi justamente neste contexto que apresentamos algumas experiências brasileiras com parques tecnológicos.

Os parques tecnológicos no Brasil resultaram da alta concentração das atividades produtivas, nas grandes metrópoles, funcionando como princípio do projeto geopolítico formado no corredor metropolitano entre Rio de Janeiro e São Paulo e a região Sul do país. Estes parques iniciais buscavam ligações entre a pesquisa e o processo produtivo. Destacaram-se nesse sentido, as experiências de São Paulo, principalmente de 
Campinas, São José dos Campos e São Carlos. Na região Sul, a experiência do Estado do Paraná nas cidades de Curitiba e Cascavel, do Estado de Santa Catarina, a cidade de Florianópolis e no Estado do Rio Grande do Sul, a cidade de Porto Alegre. Estas experiências foram realizadas para enfrentar os desafios trazidos pela globalização e para incorporar os processos relacionados à competitividade das empresas na acumulação flexível.

Por outro lado, mostramos a experiência com o Polo Industrial de Manaus (PIM) um modelo industrial tradicional, mas que possui atividades típicas de um parque tecnológico e também a sua importância socioeconômica no território usado. Apresentamos esta experiência brasileira com parques tecnológicos para enfatizar que não somente o desenvolvimento econômico deve ser priorizado nestas iniciativas. O Polo Industrial de Manaus se distingue das demais experiências brasileiras com parques tecnológicos por apresentar uma preocupação ambiental numa proposta zoneamento ecológico econômico.

Como resultado dessas considerações podemos afirmar que as experiências com parques tecnológicos no Brasil possuem algumas características comuns entre elas: a presença prévia de um processo de industrialização e de empresas de pequeno e médio porte; especializações regionais; a presença de instituições públicas de ciência e tecnologia e; a participação de empresas privadas no processo de inovação tecnológica. Podemos sugerir ainda, que as experiências brasileiras com parques tecnológicos são em geral recentes, se comparadas às de outros países o que nos leva à reflexão de possíveis contornos socioeconômicos e territoriais que estas iniciativas poderão trazer no futuro.

As experiências brasileiras com parques tecnológicos demonstram que estas surgiram voltadas ao desenvolvimento econômico, mas também como alternativa de planejamento regional. Observamos que a maior parte das iniciativas de parques tecnológicos brasileiros no território coincidiam com as áreas de concentração industrial das regiões Sul-Sudeste. Com o avanço do setor terciário no país os parques tecnológicos passaram a ser meios a produção de inovações. Na atualidade, são meios inovadores para a consolidação de um setor terciário avançado. O Parque Tecnológico Capital Digital surge justamente neste contexto. O setor de serviços avançados na metrópole brasiliense tem demandado por inovações para a melhoria de suas atividades.

No Capítulo 5 com uma aproximação do foco da análise tentamos esboçar a realidade socioeconômica de Brasília nas últimas décadas. A formação socioeconômica de Brasília implicou a presença de uma superestrutura constituída pelas instituições políticas e 
organizacionais em que o Estado foi o principal elemento dessa estrutura no processo de gestão do seu território usado. A análise da evolução urbana de Brasília demonstrou o papel importante que o Estado por meio de seus instrumentos de planejamento interferiu no território usado configurando novas estruturas capazes de refletirem a dinâmica socioeconômica da cidade.

Constatamos ainda o importante papel de Brasília de conexão no território nacional. A sua posição estratégica foi fundamental para o desenvolvimento e avanços na integração das regiões Centro-Oeste e Norte do país. Ao mesmo tempo em que seu território reunia condições de consolidação de seu papel de metrópole nacional com atividades típicas da sua função inerente a de Capital e outras de um setor terciário avançado. Brasília, com a emergência do setor de serviços apresenta formas metropolitanas que combinam adensamento disperso e policentrismo, ao mesmo tempo em que acentua o caráter concentrador da área central.

A expansão do setor de serviços na capital, a propagação de novas tecnologias e a ampliação do setor imobiliário apontam uma tendência a uma nova reorganização territorial. A partir desta tendência constatamos uma concentração dos serviços no núcleo da cidade central (Plano Piloto) e a criação de novas áreas de expansão periférica, sejam elas voltadas à instalação de condomínios horizontais para a classe média ao longo de eixos viários importantes ou para a implementação de centros de negócios, serviços e de produção de novas tecnologias como o Parque Tecnológico Capital Digital.

Inserida no contexto dos processos produtivos e espaciais que ocorrem também e outras metrópoles brasileiras se verifica em Brasília uma redução gradual dos serviços por parte do Estado na tentativa de transferência para o setor privado de todos aqueles serviços em que não existe a necessidade absoluta de serem executados por este, correspondendo tipicamente na posição de um governo urbano neoliberal que parte da premissa de que o investimento privado quando é fomentado pelo mercado, produz riqueza e gera trabalho e consequentemente o bem-estar da cidade.

As ações de gestão do território por meio de diversos planos de ordenamento territorial para a metrópole brasiliense não levaram em consideração a segregação espacial, a concentração das atividades econômicas na área central tampouco o crescimento populacional exacerbado no entorno imediato da capital. Como consequência houve o acirramento das disparidades na dinâmica urbana de Brasília. 
As discussões levantadas nos planos de ordenamento territorial nos levaram a entender que Brasília vem modificando seu tecido urbano/rural, evidenciando uma reorganização territorial. As discussões apontam para um novo padrão espacial que vem se estruturando em direção a uma conurbação acompanhando os principais eixos rodoviários, em especial do eixo sudoeste, um movimento de expansão urbana marcado por dispersão e fragmentação territorial fazendo surgir novas centralidades, como Taguatinga e Gama, apesar da existência da forte polarização do núcleo da cidade central (Plano Piloto).

Essas constatações desmistificam o nosso imaginário de Brasília, moldada e perfeita, resultante de um urbanismo racionalista. Essa cidade ideal não é a nossa cidade real, do nosso espaço vivido, das nossas intencionalidades. A cidade foi concebida em torno de uma organização monocêntrica e polinucleada e com um tecido urbano descontínuo. Todavia, entendemos que o seu desenvolvimento e as novas dinâmicas urbanas e centralidades impostas pelo seu entorno imediato evidenciam um movimento de dispersão e fragmentação do seu território usado e uma demanda crescente por serviços avançados.

O levantamento dos dados de crescimento do setor de serviços avançados nos sugeriu que estão presentes as técnicas em seu território usado para o seu desenvolvimento econômico. Assim, a capital tem procurado estabelecer sua matriz produtiva diferente da sua função administrativa para inserção na acumulação flexível. No entanto, ressalto mais uma vez, que este processo não é mecânico e pode sofrer interferências. Existem outras dinâmicas envolvidas que podem trazer mudanças com relação ao planejado.

Dessa forma, a cidade instantânea de acordo com Cidade (2014, p. 158) vem apresentando um território metropolitano consolidado com atividades do terciário avançado o que demandaria por meios inovadores como o Parque Tecnológico Capital Digital. Assim, elaborou-se com base no planejamento o projeto do Parque Tecnológico Capital Digital. A questão é que seu planejamento refletiu a visão de um dos atores envolvidos, o Governo do Distrito Federal. 
É no Capítulo 6 que tentamos ampliar a discussão também numa outra perspectiva. Até este Capítulo havia privilegiado na Tese, a tecnosfera de Milton Santos, o mundo dos objetos, da acumulação flexível e o seu meio técnico-científico. Neste Capítulo procurei trazer o sujeito/ator ao centro do debate tentando discorrer sobre as suas intencionalidades, tentando ir além da materialidade do objeto e a sua significação, mas buscando o significado que o sujeito/ator lhe dá de acordo com as suas vivências.

Estes atores/sujeitos são os recursos imateriais com diversas formas de poder sobre o território usado, um conjunto de agentes envolvidos que se relacionam visando o processo inovador. São eles, o Governo (gestores, secretários de Estado), a infraestrutura de Ciência e Tecnologia (cientistas, tecnólogos, pesquisadores), a estrutura produtiva (empresários e empreendedores). A partir do reconhecimento de quem são os atores envolvidos no processo de implantação do Parque Tecnológico Capital Digital que avançamos na discussão sobre as suas intencionalidades, estas entendidas como consequência do vivido, como resultantes da relação entre o homem e o mundo, entre o homem e o seu entorno.

Consideramos que a interação entre os atores envolvidos no processo de implementação do Parque Tecnológico Capital Digital é motivada pelo contexto social no qual estão inseridos. As suas intencionalidades são recursos imateriais fundamentais ao processo de inovação. Retomando o conceito de psicosfera de Milton Santos (1997) privilegiei na análise as ideias, a produção de sentido e a compreensão das intencionalidades dos atores envolvidos em relação ao objeto de estudo.

Por meio das entrevistas foi possível algumas inferências das intencionalidades dos atores envolvidos na implementação do Parque Tecnológico Capital Digital. Retomemos algumas considerações. Para os atores empresários representativos do setor de Tecnologia da Informação e Comunicação (TIC) no Distrito Federal o Parque Tecnológico Capital Digital representa uma tentativa de desenvolvimento de uma matriz econômica que atende as novas demandas do terciário avançado na cidade, sendo o fator mais importante para a instalação de suas empresas no Parque Tecnológico Capital Digital a concessão de incentivos fiscais, condição esta que estabelecemos como essencial no modelo de localização de parques tecnológicos apresentado no Capítulo 3. Essa visão destes atores corrobora com a visão dos atores gestores governamentais que entendem que o processo de 
implementação do Parque Tecnológico Capital Digital é primordial para o desenvolvimento econômico.

As falas nas entrevistas dos atores moradores locais da Vila Roriz, dos moradores do Varjão e do trabalhador no parque quando perguntados para que serve o parque tecnológico foram fundamentais para inferirmos sobre suas intencionalidades. Apresentaram estas falas uma diferenciação quando comparadas com os dos segmentos representativos dos atores empresários e do governo. Sugeriram elas as vivências destes atores no território usado, as suas intencionalidades e a aproximação com seu entorno daquilo que os cerca, um território apropriado. As falas destes atores (moradores locais, do Varjão e trabalhador no parque) sugeriram as percepções que têm do território usado que os cerca e, que conseguem ver despretensiosamente o desenrolar dos eventos neste.

Importante mencionar ainda que as falas dos atores moradores locais se comparadas com os outros atores sugeriram um maior conhecimento sobre o Parque Tecnológico Capital Digital no sentido do reconhecimento desta forma espacial, pois os mesmos o percebem em seu cotidiano, numa visão daquilo que propomos à apropriação conceitual da psicosfera, do espaço vivido.

As falas dos atores representativos dos pesquisadores nas entrevistas sugeriram que existem interesses conflitantes entre os atores envolvidos que podem estar impedindo os avanços no parque. As visões dos moradores da comunidade local da Vila Weslian sugeriram um distanciamento destes atores em relação ao PTCD. Nos trechos das falas das entrevistas com estes moradores inferimos o seu desconhecimento sobre membro da comunidade local que trabalhe no parque tecnológico. No meu entendimento, este distanciamento da comunidade local pode contribuir para o acirramento das desigualdades socioespaciais e ao mesmo tempo poderá produzir um "enclave" de desenvolvimento econômico inserido no contexto de um entorno imediato com realidade diferente.

Apesar do discurso institucional de que o projeto e a implantação do Parque Tecnológico Capital Digital ocorre em consenso com os demais atores envolvidos (estrutura produtiva e infraestrutura de Ciência e Tecnologia), na prática, a partir das visões colhidas dos entrevistados verificamos que a realidade é diferente. Das falas dos entrevistados representativos dos empresários e pesquisadores entendemos que não existe a interação consensual enfatizada pelo ator Governo.

Outro ponto a ser considerado também é que na sua atual fase de implantação, a ênfase imobiliária ao empreendimento tem dificultado a participação dos pequenos e micro empresários de tecnologia da informação e comunicação devido ao valor de mercado 
cobrado pelo lote destinado às empresas deste porte no parque. $\mathrm{O}$ ator Governo alega que estes empresários não se organizam em torno de um projeto comum para elaborar proposta a ser analisada pela empresa empreendedora. As falas dos atores envolvidos na implementação do Parque Tecnológico Capital Digital sugerem suas intencionalidades que podem ser facilitadoras ou complicadoras neste processo como tentamos esclarecer no Capítulo 6.

Foi possível ainda, inferir das entrevistas com os moradores da comunidade local as visões destes em relação a possíveis danos ambientais causados pela presença do parque em seu entorno imediato ou da interferência do mesmo em seus cotidianos. Como forma espacial da acumulação flexível o parque tecnológico apesar de ser considerado uma indústria limpa pode provocar algum dano no território usado, mas de proporção menor se comparados com outras formas produtivas como a indústria pesada de transformação. Como alternativa aos possíveis problemas ambientais observados no Parque Tecnológico Capital Digital, além da responsabilização ambiental (reparação ambiental) ao empreendedor responsável, cumpre destacar o papel afirmativo do Zoneamento Ecológico Econômico como instrumento de regulação das práticas (ações) no território usado como foi apresentado em relação ao PIM (Polo Industrial de Manaus) no Capítulo 4.

O Parque Tecnológico Capital Digital foi pensado como uma alternativa para as mudanças produtivas presentes na cidade. Desde a sua concepção até o momento atual de implantação podemos apontar algumas realizações importantes como a definição da área, a localização, a infraestrutura e as empresas âncoras instaladas no parque. Mas para avançar em sua implementação, somente o atendimento das necessidades da tecnosfera não parecem ter sido suficientes. Tornou-se necessário ir além do viés econômico inerente e fundamental ao empreendimento. Este estudo apontou que na psicosfera, as intencionalidades dos atores envolvidos no Parque Tecnológico Capital Digital também podem influenciar na sua implementação, pois existem interesses conflitantes no processo.

Os avanços no processo de implementação do Parque Tecnológico Capital Digital passam pela tentativa de solução dos conflitos existentes entre os atores envolvidos. Existe uma diversidade de ideias, de intencionalidades. Assim, considero que a solução destes conflitos de interesses está em reconhecer que a diversidade das intencionalidades destes atores estão relacionadas às práticas de poder que estes exercem no território usado. Não devemos nos reduzir com perplexidade e imobilidade diante destes conflitos, mas sim buscarmos as suas origens, os seus fatores condicionantes para definir um método de solução destes. Assim, partindo de uma visão integradora das intencionalidades dos atores 
envolvidos é que vamos avançar no processo de implementação do Parque Tecnológico Capital Digital. A superação dos conflitos de maneira construtiva é sempre um processo que exige o diálogo e a conscientização para a cooperação entre os atores envolvidos no processo.

Sugestões para desdobramentos em futuros estudos

Esta Tese se constituiu em primeira tentativa em realizar estudos sobre parques tecnológicos para além da tecnosfera, que em geral privilegiam os fatores econômicos. Não deixei de abordar esta perspectiva mais desejei enfatizar também a importância da outra, a psicosfera com as intencionalidades dos atores envolvidos e pela própria peculiaridade que o objeto de estudo apresentou. O estudo não se encontra encerrado e se abre a novas possibilidades de análise.

A questão da mobilidade urbana foi citada pelos empresários entrevistados. A importância de acessibilidade ao sistema de transporte está entre as vantagens locacionais mencionadas pelos atores envolvidos. Uma nova pesquisa poderia tratar do desenvolvimento do transporte coletivo no eixo viário norte para viabilizar o acesso ao parque tecnológico. Dessa forma, os atores poderiam promover ação junto ao Governo do Distrito Federal para incentivar o desenvolvimento de propostas para o corredor de transporte coletivo de massa (metrô) no eixo viário norte da cidade próximo ao Parque Tecnológico Capital Digital.

Com os avanços na implantação do Parque Tecnológico Capital Digital e a presença maciça de pequenas empresas em sua área poderia ser realizada nova pesquisa para verificar os efeitos facilitadores do parque àquelas que não são fornecedoras das grandes empresas nele instaladas e nem estão sob o regime de subcontratação. Poderia ainda, ser realizada nova pesquisa sobre a interferência do Parque Tecnológico Capital Digital na comunidade local do seu entorno imediato. 


\section{REFERÊNCIAS BIBLIOGRÁFICAS}

AB'SABER, Aziz Nacib. Geografia e planejamento. São Paulo: Instituto de Geografia da Universidade de São Paulo, 1969.

ACKOFF, Russel L. Planejamento empresarial. Rio de Janeiro: Livros técnicos e científicos, 1979.

ALBUQUERQUE, L. G. Distrito Federal: avaliação do déficit habitacional. Brasília: SHIS, 1983.

ÁLVARES, Oto Morato. Inovação e Marketing. In: CASTRO-LUCAS, Cristina (org.). Empreendedorismo e Inovação Tecnológica. Brasília: Centro de Apoio ao Desenvolvimento Tecnológico - CDT/UnB, 2013.

ANDRADE, Manuel Correia de. Espaço, Polarização e Desenvolvimento. Recife: CRAM, 1967.

ANDRADE, Manuel Correia de. Territorialidades, desterritorialidades, novas territorialidades: os limites do poder nacional e do poder local. In: SANTOS, Milton; SOUZA, Maria Adélia de; SILVEIRA, Maria Laura (orgs.). Território, Globalização e Fragmentação. São Paulo: Hucitec, 1994.

ANPROTEC, ABDI, MCT. Parques Tecnológicos no Brasil: estudos, análises e proposições. Brasília, 2008.

ANPROTEC. Portfólio de parques tecnológicos do Brasil. Brasília: 2008. 78p.

ANPROTEC. Incubadoras e parques. Brasília: 2015. Disponível em: $<$ http://www.anprotec.org.br>. Acesso em out. 2015.

ARAÚJO, T. Ensaios sobre o Desenvolvimento Brasileiro, Heranças e Urgências. Rio de Janeiro: Fases, 2000.

ARBIX, Glauco. Inovar ou inovar: a indústria brasileira entre o passado e o futuro. São Paulo: Editora Papagaio, 2007.

AZZONI, C.R. Setor terciário e concentração regional no Brasil. In: DINIZ, C.C.; LEMOS, M.B. (orgs.) Economia e território. Belo Horizonte: UFMG, 2005.

AYDALOT, Philippe. Trajectories Techonologiques et Milleux Innovateurs.GREMI Groupe de Recherche Européen sur les Milleux Innovateurs. Neuchatel, 1986. Disponível em: <http://www.unine.ch>. Acesso em mar. 2016. 
BAER, Werner. Brasil: determinantes políticos do desenvolvimento. In: Cadernos de Estudos Sociais. Recife: vol. 1, nº 3, jan-jun, 1986.

BAUMANN, Renato. O Estado: Salva-Vidas na Índia, Garantia de Bem-estar na Bélgica, ou motor de crescimento de Berlíndia? Planejamento e Políticas Públicas. CEPAL, 1993.

BECKER, Bertha K. Geografia Política e Gestão do Território no Limiar do Século XXI: uma representação a partir do Brasil. Revista Brasileira de Geografia. Rio de Janeiro, v.53, n.3, p. 169-182, 1991.

BECKER, Bertha K; EGLER, Cláudio. A. G. Brasil: uma nova potência regional na economia-mundo. Rio de Janeiro: Bertrand Brasil, 1994.

BENKO, Georges. Economia, espaço e globalização: na aurora do século XXI. São Paulo: Hucitec, 1996.

BERMÚDEZ, Luís Afonso (coord.). Gestão da tecnologia: capacitação empresarial a distância. Brasília: CDT/UnB, 2013.

BERNADES, Júlia Adão. Mudança Técnica e Espaço: uma proposta de investigação. In: CASTRO, Iná Elias de; GOMES, Paulo César da Costa; CORRÊA, Roberto Lobato (orgs.). Geografia: Conceitos e Temas. Rio de Janeiro: Bertrand Brasil, 1995.

BICCA, P. Brasília: mitos e realidades. In: PAVIANI. A.; BICCA, P. (orgs.). Brasília, ideologia e realidade: espaço urbano em questão. São Paulo: Projeto, 1985.

BORRÁS, S. LUNDVALL, B. Repensant la racionalitat des lês polítiques científiques, tecnológiques i d'innovació des le la perspectiva del coneixement. 2003. Disponível em: <http://www.druid.dk/ index.>. Acesso em abr. 2014.

BRANDÃO, Arnaldo Barbosa. Morar e Viver: Um estudo sobre a habitação das famílias pobres. Brasília: UnB, 1982.

BRASIL. IBGE. Indicadores - 2006. Disponível em: <http://www.ibge.gov.br>. Acesso em abr. 2014.

BRASIL. IBGE. Indicadores. Disponível em: <http://www.ibge.gov.br>. Acesso em nov. 2015.

BRASIL. IBGE. Censo Demográfico, 2010. Disponível em: 〈http://www.ibge.gov.br>. Acesso em mar. 2014.

BRASIL. MPOG - Ministério do Planejamento, Orçamento e Gestão. Plano Plurianual 2004/2007. Disponível em: <http://www.planejamento.gov.br>. Acesso em jan. 2016. 
BRASIL. MPOG - Ministério do Planejamento, Orçamento e Gestão. Assuntos Econômicos. Disponível em: <http://www.planejamento.gov.br>. Acesso em nov. 2015.

BRESSER-PEREIRA, L. C. O novo desenvolvimentismo e a ortodoxia convencional. São Paulo em perspectiva, v. 20, n. 3, p. 5-25, 2006. Disponível em <http://www.seade.gov.br/wp-content/uploads/2014/07/v20n3.pdf> Acesso em jan. 2016.

BRINDLEY, T.; RYDIN, Y; STOKER, G. Remaking planning: the politics of urban change. Nova Iorque: Routledge, 2004.

BRYSON, John M. Strategic planning for public and nonprofit organizations. São Francisco: Josseey-Bass Publishers, 1988.

BUARQUE, Cristovam R.O. A desordem do progresso: o fim da era dos economistas e a construção do futuro. Rio de Janeiro: Paz e Terra, 1990.

BUARQUE, Cristovam R. "A reinauguração de Brasília" (Introdução). GDF. Plano de Desenvolvimento Econômico do Distrito Federal. Brasília: GDF, 1996.

CAMPOS, Renato; et al. Sistemas locais de inovação: casos selecionados em Santa Catarina. In: CASSIOLATO, José E.; LASTRES, Helena M. M. (edis.). Globalização \& inovação localizada: experiências de sistemas locais no Mercosul. Brasília: IBICT/MCT,1999.

CANO, Wilson. Perspectivas do desenvolvimento econômico do interior paulista. In: TARTAGLIA, J.C.; OLIVEIRA, O.L. Modernização e desenvolvimento do interior de São Paulo. São Paulo: Ed. Unesp, 1988.

CARLOS, Ana F. Espaço e Indústria. São Paulo: Contexto, 1988.

CARNEIRO DA CUNHA, J. A.; PASSADOR, J.L.; PASSADOR, C.S. Recommendations and notes for cartegorizations in research on interoganizational networks. Cadernos EBAPE.BR. Rio de Janeiro: FGV, v.9, jul, 2011.

CARVALHO, José Otamar de (coord.). Plano Estratégico de Desenvolvimento Sustentável da Região Centro-Oeste - Planoeste. Brasília: IICA/ICPD, 1999.

CASTELLS, M,; HALL, P. Technopoles of the world. London: Routledge, 1994.

CASTELLS, Manuel. A era da informação: economia, sociedade e cultura. São Paulo: Paz e Terra, 1999.

CASTELLS, Manuel. A sociedade em rede. A era da informação: economia, sociedade e cultura. São Paulo: Paz e Terra, 2001.

CATTANI, Antônio David. Trabalho \& Autonomia. Petrópolis: Vozes, 1996.

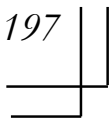


CERON, A. O.; GERARDI, L. H. O. Bases geográficas para planejamento rural no Estado de São Paulo. Geografia. Rio Claro: AGETEO, v. 6, n. 11-12, p. 108, 1981.

CHIESA, V. Globalizing R\&D Around Centres of Excellence. Long Range Planning, v. 28, n. 6, p. 19-28, 1995.

CHU, J. The status and role of university Science park in relation to universities, government and the industry. XXII IASP World Conference on Science and Tecnology Parks, Beijing, 2005.

CIDADE, Lúcia Cony Faria; FERREIRA, Ignez Costa Barbosa. Novos rumos para a gestão do território: da gestão autoritária à participação popular. Relatório de Pesquisa. Brasília: NEUR/CEAM - UnB, out, 1997.

CIDADE, Lúcia Cony Faria. Planejamento das cidades: modelos tradicionais e tendências contemporâneas. Espaço e Geografia. Brasília: EdunB, 1998.

Acumulação flexível e gestão do território no Distrito Federal. In: PAVIANI, Aldo (org.). Brasília - gestão urbana: conflitos e cidadania. Brasília: EdUnB, 1999.

The Instant city. In: KNOX, Paul (ed.) Atlas of cities: mapping the origins, development, and impacts of urbanization. Princeton New Jersey, Princeton University Press, August 2014. 256 pp. p. 158-175.

CIDADE, L. C. F.; VARGAS, G. M; JATOBÁ, S. U. Regime de acumulação e configuração do território no Brasil. Cadernos Metrópole, São Paulo, n. 20, p. 13-35, 2008.

COBRA, Marcos. Planejamento estratégico de marketing. São Paulo: Atlas, 1991.

CODEPLAN/GDF. Relatório Belcher: $O$ relatório técnico sobre a nova capital da República. Brasília: GDF, 1995.

PDOT - Plano Diretor de Ordenamento Territorial. Brasília: GDF, 1996.

Anuário Estatístico do Distrito Federal - 1995-1996. Brasília: GDF, 1996.

Anuário Estatístico do Distrito Federal - 2001. Brasília: GDF, 2001. Disponível em: <http://www.codeplan.df.gov.br>. Acesso em fev. 2014.

Anuário Estatístico do Distrito Federal - 2013. Brasília: GDF, 2013. Disponível em: <http://www.codeplan.df.gov.br〉. Acesso em nov. 2015.

COHN, Gabriel. Problemas da industrialização no século XX. In: MOTA, C. G. (org.). Brasil em perspectiva. São Paulo: DIFEL, 1977. 
COLELA, P. M. O que não mudou na habitação popular: dos cortiços à comercialização de moradias em Brasília. Brasília, UnB, dissertação (mimeo), 1991.

COMPANS, R. Empreendedorismo urbano: entre o discurso e a prática. São Paulo: UNESP, 2005.

CORRÊA, Roberto Lobato. Trajetórias geográficas. Rio de Janeiro: Bertrand Brasil, 1997.

COSTA, Everaldo B.; PELUSO, Marília L. Imaginário urbano e situação territorial vulnerável na Capital do Brasil. Biblio3w, vol. XXI, nº1151, 2016.

CRULS, L. Relatório da Comissão Exploradora do Planalto Central: relatório Cruls. Brasília: GDF/CODEPLAN, 1992.

CUNHA, Julio Araujo Carneiro da; PASSADOR, João Luiz; PASSADOR, Cláudia Souza. Recomendações e apontamentos para categorizações em pesquisas sobre redes interorganizacionais. Cad. EBAPE.BR, vol.9, n.spe1, pp. 505-529, 2011.

CYSNE, Rubens Penha. Plano Collor: contra factualidade e sugestões sobre a condução política monetária-fixa. ENCONTRO NACIONAL DE ECONOMIA, 18, 1990, São Paulo. Anais. São Paulo: ANPEC, 1990, p. 711-735.

DAS, T. K.; TENG, B. Alliance constellations: a social exchange perspective. Academy of Management Review, v.27, n.3, p.445-456, 2002.

DAVIDOVICH, Fany. Gestão do Território, um tema em questão. Revista Brasileira de Geografia, Rio de Janeiro, v. 3, n.53, p.7-31,1991.

DEFEVER, F. Functional fragmentation and the location of multinational firms in the enlarged Europe. Regional Science and Urban Economics, v. 36, n. 5, p. 658-677, 2006.

DEVEREUX, M. P; GRIFFITH, R.; SIMPSON, H. Firm location decisions, regional grants and agglomeration extenalities. Journal of Public Economics, v. 91, n. 3-4, p.413435, 2007.

DINIZ, C.C.; CROCCO, M.C. (orgs.) Economia regional e urbana: contribuições teóricas recentes. Belo Horizonte: UFMG, 2006.

DODF. DIÁRIO OFICIAL DO DISTRITO FEDERAL. Disponível em: <http://www.buriti.df.gov.br>. Acesso em jan. 2014.

DIÁRIO OFICIAL DO DISTRITO FEDERAL. Brasília Revisitada por Lúcio Costa. Brasília: DODF, 1987. 
DUNNING, J. H. Multinational enterprises and the globalization of innovatory capacity. Research Policy, v. 23, p. 67-88, 1994.

DUPAS, Gilberto. Economia global e exclusão social: pobreza, emprego, Estado e o futuro do capitalismo. São Paulo: Paz e Terra, 2000.

EDWARDS, R. W.; BUCKLEY, P.J. Choice of location and mode: the case of Australian investors in UK. International Business Review, v.7, n. 5, p. 503-520, 1998.

ESTRADA, Rafael Edwing V. Ensaios de interpretação de políticas habitacionais na América do Sul: subsídios para o estudo comparativo de políticas habitacionais. Brasília: Dissertação de Mestrado - Departamento de Arquitetura e Urbanismo, UnB, 1988.

FABERON, J. Y. Technopoles et développement. Revue Française de Science Politique. Paris: 40(1), 1990.

FERREIRA, I.C.B. Gestão do espaço agrário. X ENCONTRO NACIONAL DE GEOGRAFIA AGRÁRIA. Rio de Janeiro: dez, 1990.

FERREIRA, Ignez Costa B.; PENNA, Nelba A. Brasília: novos rumos para a periferia. In: PAVIANI, Aldo (org.). Brasília: moradia e exclusão. Brasília: EDUnB,1996.

FERREIRA, Ignez Costa B.; STEINBERGER, Marília. O modelo de gestão de Brasília e as políticas urbanas nacionais. Caderno METRÓPOLE [online]. 2006.

FIGUEIREDO, Paulo César Negreiros. "O Triângulo de Sábato" e as alternativas brasileiras de inovação tecnológica. Revista de Administração Pública, Rio de Janeiro, v. 27(3), p.84-97, 1993.

FRASSOLDATI, F. Dramatically innovative: science and technology parks as urban regenerators in Italian cities, 2008. Disponível em <www.corporationsandcities.org>. Acesso em jan. 2016.

GDF/SVO/DAU/TERRACAP. Plano Estrutural de Ocupação Territorial do Distrito Federal. Brasília: GDF/SVO/DAU, 1985.

GDF. Plano de Ordenamento Territorial do Distrito Federal. Brasília: IPDF/GDF, 1996. 1996.

Plano de Desenvolvimento Econômico do Distrito Federal. Brasília: GDF,

GOLDENSTEIN, L. Repensando a dependência. Rio de Janeiro: Paz e Terra, 1994. 
GOMES, Gustavo Maia. Políticas de desenvolvimento regional no mundo contemporâneo (e algumas de suas implicações para o Brasil). Rio de Janeiro: CNI, 1993.

GONÇALVES, R. A empresa transnacional. In: KUPFER, D.; HASENCLEVER, L. (org.). Economia Industrial: fundamentos teóricos e práticas no Brasil. Rio de Janeiro: Campus, 2002.

GOUVEIA, J. B. Parques de ciência e tecnologia no Porto. Porto: Universidade do Porto, 1991.

GRANOVETTER, M. Economic action and social structure: the problem of embeddedness. American Journal of Sociology, v.91, n.3, p.481-510, 1985.

HAESBAERT, Rogério. Desterritorialização: entre as redes e os aglomerados de exclusão. In: CASTRO, Iná Elias de; GOMES, Paulo César da Costa; CORRÊA, Roberto Lobato (orgs.). Geografia: Conceitos e Temas. Rio de Janeiro: Bertrand Brasil, 1995.

HARDT, Carlos. Parques tecnológicos europeus e espaço urbano. In: PALADINO, Gina (org.), MEDEIROS, Lucília A.. (org.). Parques Tecnológicos e Meio Urbano: artigos e debates. Brasília: ANPROTEC, GTU International, 1997. p. 225-236.

HARVEY, David. A Justiça Social e a Cidade. São Paulo: Hucitec, 1980.

The limits to Capital. Oxford: Blackwell, 1982.

A Condição Pós-Moderna. São Paulo: Loyola, 1992.

A Produção Capitalista do Espaço. São Paulo: Annablume, 2001.

A produção Capitalista do Espaço. São Paulo: Annablume, 2005.

Os Limites do Capital. São Paulo: Boitempo, 2013.

HISSA, Cássio Eduardo Viana. A mobilidade das fronteiras. Inserções da geografia na crise da modernidade. Belo Horizonte: UFMG, 2002.

HU, Albert Guangzhou. Technology parks and regional economic growth in China. Research Policy, v. 36, p. 76-87, 2007.

Innovation and Economic Growth in East Asia: An Overview. Asian Economic Policy Review, v. 10, p. 19-37, 2015.

IASP. INTERNATIONAL ASSOCIATION OF SCIENCE PARKS. Definitions and Statistics. Disponível em: 〈http://www.iasp.ws>. Acesso em jan. 2014. 
IPEA. O Brasil em 4 décadas. Rio de Janeiro: IPEA, 2010.

Dados Regionais. Brasília: IPEA, 2010. Disponível em: <www.ipeadata.gov.br>. Acesso em abr. 2014.

JONES, C.; HESTERLY, W. S.; BORGATTI, S. P. A general theory of network governance: exchange conditions and social mechanisms. Academy of Management Review, v.22, n.4, p.911-945, 1997.

KOSHIBA, Luiz; PEREIRA, Denise Manzi Frayze. História do Brasil. São Paulo: Atual, 1993.

KOSIK, Karel. Dialética do concreto. São Paulo: Paz e Terra, 1969.

KUMAR, Krishan. Da sociedade pós-industrial à pós-moderna: novas teorias sobre o mundo contemporâneo. Rio de Janeiro: Jorge Zahar, 1997.

LACERDA, N.; ZANCHETTI, S. M.; DINIZ, F. Planejamento metropolitano: uma proposta de conservação urbana e territorial. Eure, no 79, vol. 26, pp. 77-94, 2000.

LACERDA, Norma. Fragmentação e integração: movimentos de (re)estruturação espacial das metrópoles brasileiras. In: XIV ENCONTRO DA ANPUR, 2011, Rio de Janeiro: (mimeo), 2011, pp.21-42.

LASTRES, H. M.M.; FERRAZ, J. C. Economia da informação, do Conhecimento e do Aprendizado. In: LASTRES, H. ALBAGLI, S. (eds). Informação e Globalização na Era do Conhecimento. Rio de Janeiro: Campus, 1999.

LEMOS, C; ALBAGLI, S.; SPAZIRO, M. Políticas de promoção e arranjos produtivos locais no Brasil: evolução recente e desafios atuais. In: LASTRES, H. M; CASSIOLATO, J. E. (orgs.). Estratégias para o desenvolvimento: um enfoque sobre arranjos produtivos locais no Norte, Nordeste e Centro-Oeste brasileiros. Rio de Janeiro: Epapers, 2006.

LENCIONI, Sandra. Condições gerais de produção: um conceito a ser recuperado para a compreensão das desigualdades de desenvolvimento regional. Revista Scripta Nova, v. 38, n. 245, 2007. Disponível em <www.scielo.cl. > Acesso em Abr. 2016.

Concentração e centralização das atividades urbanas: uma perspectiva multiescalar. Reflexões a partir do caso de São Paulo. Revista de Geografia Norte Grande, Santiago, n. 39, p. 7-20, 2008. Disponível em <www.scielo.cl. > Acesso em Fev. 2016.

LIMA, Luiz Cruz. Parque tecnológico, instrumento de desenvolvimento regional? In: CONFERENCE: THE REGIONAL QUESTION AND SOCIAL MOVEMENTS IN THIRD WORLD. São Paulo: USP, 1991. 
Parque tecnológico: a formação de uma nova territorialidade. In: Fim de século e globalização. São Paulo: Hucitec/ANPUR, 1993.

LIMONAD, Ester. Urbanização Dispersa mais uma forma de expressão urbana. Revista Formação, no 14, vol. 01, 2006.

LIPIETZ, Alain. O Capital e seu Espaço. São Paulo: Nobel, 1988.

LOPES, W. W. Ceilândia tem Memória, duas décadas, meio milhão de habitantes. Brasília: Comunidade, 1993.

MACIEL, Maria Lúcia. Cultura e inovação em Brasília. In: NUNES, Brasilmar Ferreira (org.). Brasília: a construção do cotidiano. Brasília: Paralelo 15, 1997.

MAILLAT, D. La relation des entreprises innovatrices avec leur milieu. In:MAILLAT, D.; PERRIN, J.C. (eds.). Entreprises innovatrices et développement territorial. GREMI Groupe de Recherche Européen sur les Milleux Innovateurs. Neuchatel, 1986. Disponível em: <http://www.unine.ch>. Acesso em mar. 2016.

MAMIGONIAN, Armen. Introdução ao pensamento de Ignácio Rangel. Florianópolis: UFSC, v.2, n.3, 1987. Disponível em <www.periódicos.ufsc.br >. Acesso em Fev. 2016.

MCALLISTER, M.; MOURA, S. Cidade Estratégica e a Gestão Empreendedora: uma operação de planejamento, pacto e marketing. Organizações e Sociedade. Salvador: UFBA, 1996.

MALERBA, F. Sectoral System: How and why innovation differs across sectors. In: FAGERBERG, J.; MOWERY, D. NELSON, R. The Oxford handbook of innovation. Nova Iorque: Oxford University Press, 2005.

MARTELETO, R. M; SILVA, A. B. O. Redes e capital social: o enfoque da informação para o desenvolvimento local. Ciência da Informação, v.33, p.41-49, 2004.

MASSEY, D; QUINTAS, P.; WIELD, D. Hightech fantasies: Science Parks in Society, Science and Space. London: Routledge, 1992.

MASSEY, D. Pelo espaço: uma nova política da espacialidade. Rio de Janeiro: Bertrand Brasil, 2008.

MATTOS, L.B. de; CASSUCE, F. C. da C.; CAMPOS, A. C. Determinantes do investimentos diretos estrangeiros no Brasil, 1980-2004. Revista de Economia Contemporânea, v. 11, n.1, p. 39-60, 2007.

MEDEIROS, J. A.; MATTEDI, A. P.; DE MARCHI, M. M. Polos tecnológicos e núcleos de inovação: lições do caso brasileiro. Revista de Administração, São Paulo, v. 25(4), p.3-12, 1990. 
MEDEIROS, José Adelino. Estruturas e espaços voltados à inovação e parceria: o papel dos polos e parques tecnológicos. In: MEDEIROS, José Adelino; ATAS, Lucília; MARTINS, Thereza; PERILO, Sérgio (orgs.). Polos, Parques e Incubadoras: a busca de modernização e competitividade. Brasília: ANPROTEC, 1997.

MEDEIROS, José Adelino; ATAS, Lucília; MARTINS, Thereza; PERILO, Sérgio (orgs). Polos, Parques e Incubadoras: a busca de modernização e competitividade. Brasília: ANPROTEC, 1997.

MELLO, João Manuel C. de. O Capitalismo Tardio. São Paulo: Brasiliense, 1982.

MENDES, Auro Aparecido. Condomínios Industriais em Atibaia-SP: o espaço mudando a indústria e as políticas territoriais. Espaço e Economia, n.4, p. 1-9, 2014. Disponível em <www.espacoeconomia.revues.org >. Acesso em fev. 2016.

NARAYAN, D. Bonds and bridges: social capital and poverty. In: ISHAM, J.; KELLY, T.; RAMASWAMY, S. (Orgs.). Social capital and economic development: well-being in developing countries. Cheltenham: Edgar Elgar, 2002.

NASCIMENTO, Elimar Pinheiro. Estado e sociedade no Brasil: Novos Padrões de Relacionamento? Brasília: Conselho de Justiça Federal - CEJ, 1996.

NOCE, Adriana F. R. O processo de implantação e operacionalização de um parque tecnológico. Florianópolis: UFSC, 2002.

OCDE. OSLO manual. 2015. Disponível em: 〈http://www.oecd.org>. Acesso em mar. 2016.

OH, D. S.; MASSER, I. High-tech Centres and the Regional Innovation: some case studies in the Uk, Germany, Japan and Korea. In: BERTUGLIA, C.S.; FISCHER, M.M.; PRETO, G. Technological Change, Economic Development and Space. Berlim: Springer, 1995.

ORBORNE, D.; GAEBLER, T. Reinventing Government: how the entreprenurial spirit is transforming the public sector. London: Plume, 1993.

OSÓRIO, L. Planejamento, sociedade urbana e inovação tecnológica. In: RIBEIRO, Ana Clara Torres ; MACHADO, Denise B. Pinheiro (orgs.). Metropolização e rede urbana: perpectivas dos anos 90. Rio de Janeiro: UFRJ/IPPUR, 1990.

PARK, S. H. Managing an interorganizational network: a framework of the institutional mechanism for network control. Organization Studies, v. 17, p.5-21, 1996.

PASSOS, Carlos Artur Krüger. Sistemas locais de inovação: o caso do Paraná. In: CASSIOLATO, José E.; LASTRES, Helena M. M. (edis.). Globalização \& inovação localizada: experiências de sistemas locais no Mercosul. Brasília: IBICT/MCT,1999. 
PAVIANI, Aldo. A metrópole terciária. In: PAVIANI. A.; BICCA, P. (orgs.). Brasília, ideologia e realidade: espaço urbano em questão. São Paulo: Projeto, 1985.

Periferização Urbana. In: PAVIANI, A. (org.). Urbanização e Metropolização: a gestão dos conflitos em Brasília. Brasília: EdUnB, 1987.

A realidade da Metrópole: Mudança ou Transformação na Cidade? Brasília: EdUnB,1992.

A realidade da Metrópole: Mudança ou Transformação na Cidade? In: PAVIANI, Aldo (org.). Brasília: Moradia e Exclusão. Brasília: EdUnB,1996.

Conceituação de Gestão do Território: o caso do Aglomerado Urbano de Brasília e sua área de influência. Seminário alternativas de gestão do território para o aglomerado urbano de Brasília. Brasília, UnB, nov, 1997.

PELUSO, M. L.; CIDADE, L.C.F. Meio ambiente, expansão urbana e desafios territoriais em Brasília. III ENCONTRO DA ASSOCIAÇÃO NACIONAL DE PESQUISA E PÓSGRADUAÇÃO EM ARQUITETURA E URBANISMO - III ENANPARQ. São Paulo, 2014.

PELUSO, M.L.; PANTOJA, W.R.; ARTEAGA, P.E.M; ARAÚJO, M.L. Espaço, Tempo e Natureza: o processo e o mito. Revista Eletrônica: Tempo, Técnica - Território,v.6, n.1, p.1-23, 2015.

PENNA, Nelba Azevedo. Política Urbana: a ação do Estado no Distrito Federal. Brasília: IAU-UnB,1991.

Planejamento urbano e estratégias empreendedoras em Brasília. Finisterra, XLVII, v. 93, p. 109-127, 2012.

PERROUX, François. O conceito de Polo de Crescimento. In: SCHWARTZMAN, Jacques. Economia Regional. Belo Horizonte: CEDEPLAR/ UFMG, 1977.

PINTO, Dolores Gonçalves. Desenvolvimento no setor industrial de alta tecnologia: estratégias para o Distrito Federal. Brasília: Secretaria de Assuntos Estratégicos, 1996.

PROVAN, K. G.; KENIS, P. Modes of network governance: structure, management, and effectiveness. Journal of Public Administration Research and Theory, v.18, n.2, p.229$257,2008$.

QUEVTT, M. Un modèle de développement régional? In: La Tribune de l' Expansion. Paris: Special Technopoles, 1988.

QUIVY, R.; CAMPENHOUDT, L. V. Manual de Investigação em Ciências Sociais. Lisboa: Gradiva, Trajectos, 1998. 
RAFFESTIN, Claude. Por uma geografia do poder. São Paulo: Ática, 1993.

REBELLO, Antônio Augusto Huebel. Projeto Brasília Tecnópole. In: MEDEIROS, José Adelino; ATAS, Lucília; MARTINS, Thereza; PERILO, Sérgio. Polos, Parques e Incubadoras: a busca de modernização e competitividade. Brasília: ANPROTEC, 1997.

RIBEIRO, A. F.; SPOLIDORO, R. Parque Capital Digital. Brasília: SINFOR, 2006.

HOLANDA, F; RIBEIRO, R.J.C; A Metrópole de Brasília na rede urbana brasileira e configuração interna. RIBEIRO, R.J.C; TENÓRIO, G.S; HOLANDA, F. (orgs.). Brasília: transformações na ordem urbana. Rio de Janeiro: Letra Capital, 2015.

ROVATI, J. F. Urbanismo versus Planejamento Urbano? Revista Brasileira de Estudos Urbanos e Regionais, v. 15, n.1, p.33-58, 2013.

SÁBATO, J. A.; BOTANA, N. La ciencia e tecnología en desarrollo futuro de America Latina. In: SÁBATO, J. A. (comp.) El pensamiento lationoamericano en la problemática ciencia-tecnología-desarrollo. Buenos Aires: Paidos, 1975.

SÁENZ, Tirso W; GARCÍA CAPOTE, Emílio. Ciência, inovação e gestão tecnológica. Brasília: CNI/IEL/SENAI/ABIPTI, 2002.

SANTOS, C. P. Tecnopolos e desenvolvimento local: potencialidades e limites na proposta Brasília Tecnópolis. Brasília, UnB, dissertação (mimeo), 2001.

SANTOS, Milton. Por uma Geografia Nova. São Paulo: Hucitec, 1978.

Espaço e método. São Paulo: Nobel, 1985.

Novos rumos da Geografia brasileira. São Paulo: Hucitec, 1988.

Por uma outra Globalização: do pensamento único à consciência universal. Rio de Janeiro: Record, 2000.

2006.

A natureza do espaço: técnica e tempo: razão e emoção. São Paulo: Edusp,

O espaço do cidadão. São Paulo: EDUSP, 2007.

SANTOS, Milton. A aceleração contemporânea: tempo mundo e espaço-mundo. In: DOWBOR, Ladislau, IANNI, Octavio; (et al) (orgs.). Desafios da Globalização. Rio de Janeiro: Vozes, 1997.

SANTOS, M.; SOUZA, M.A.; SILVEIRA, M.L. (orgs.). Território, Globalização e Fragmentação. São Paulo: Hucitec, 1998. 
SANTOS, M.; SILVEIRA, M. L. O Brasil: território e sociedade no início do século XXI. Rio de Janeiro: Record, 2003.

SANTOS, Raul C. dos; VERMULM, Roberto. Novas formas de atuação no desenvolvimento regional - infraestrutura tecnológica como instrumento de desenvolvimento regional. São Paulo: IPEA, 1997.

SAQUET, M. A. Abordagens e concepções de território. São Paulo: Expressão Popular, 2007.

SAULE JR. N.; ROLNIK, R. O estatuto da cidade e o plano diretor. In: OSÓRIO, L.M. (org.). Estatuto da cidade e reforma urbana: novas perspectivas para as cidades brasileiras. Porto Alegre: Sérgio Antônio Fabris Editor, 2002.

SCHVASBERG, B. Desafios ao planejamento e à gestão territorial integrada da Área Metropolitana de Brasília. Brasília em debate. Brasília: CODEPLAN, n. 01, p.23-28, 2012.

SEPLAN/GDF. Plano Estrutural de Organização Territorial do Distrito Federal. Brasília: SEPLAN/GDF, 1977.

SINFOR. Parque Tecnológico Capital Digital. Brasília: SINFOR, 2015.

SMITH, N. Desenvolvimento Desigual. Natureza, Capital e a produção do espaço. Rio de Janeiro: Bertrand Brasil, 1988.

SOBRAL, Gilberto (coord.) (et al.). Perfil do Distrito Federal e Guia do Investidor: versão 1998. Brasília: Secretaria de Indústria e Comércio, 1998.

SOBRINHO, Fernando L.A. (et al.). Saneamento ambiental na RIDE-DF e a configuração dos territórios de tensão. Revista Geográfica da América Central, Costa Rica, ${ }^{\circ}$ esp. p. $1-16,2011$.

SOJA, Edward W. Geografias pós-modernas: a reafirmação do espaço na teoria social crítica. Rio de Janeiro: Jorge Zahar, 1993.

SOUZA, M. J. L. O território: sobre espaço e poder, autonomia e desenvolvimento. In: CASTRO, Iná Elias de; GOMES, Paulo César da Costa; CORRÊA, Roberto Lobato (orgs.). Geografia: Conceitos e Temas. Rio de Janeiro: Bertrand Brasil, 1995.

SOUZA, Marcelo Lopes de. Mudar a Cidade. Uma Introdução Crítica ao Planejamento e à Gestão Urbanos. Rio de Janeiro: Bertrand Brasil, 2002.

SOUZA, Maria C.; GARCIA, Renato. Sistemas locais de inovação em São Paulo. In: CASSIOLATO, José E.; LASTRES, Helena M. M. (edis.). Globalização \& inovação localizada: experiências de sistemas locais no Mercosul. Brasília: IBICT/MCT,1999. 
SPOLIDORO, R. A sociedade do conhecimento e seus impactos no meio urbano. In: PALADINO, Gina; MEDEIROS, Lucília A. (orgs.). Parques Tecnológicos e Meio Urbano: artigos e debates. Brasília: ANPROTEC, GTU International, 1997.

SPOLIDORO, R. Diretrizes estratégicas para o parque tecnológico do Vale dos Sinos. Novo Hamburgo: Feevale, 2006.

SPOLIDORO, R; AUDY, J. Parque Científico e Tecnológico da PUCRS. Porto Alegre: EDIPUCRS, 2008.

SPOSITO, M. E. B. Capitalismo e Urbanização. São Paulo: Contexto, 1988.

STORPER, M. High-technology Industry and Regional Development: a Theoretical Critique and Reconstruction. International Social Science Journal, n. 112, 1988.

STORPER, M. A industrialização e a questão regional no Terceiro Mundo. In: VALLADARES, L.; PRETECEILLE, E. (orgs.). Reestruturação urbana: tendências e desafios. São Paulo: Nobel - IUPERJ, 1990.

STUMPFL, A. University research parks - academic advantages for R\&D. San Francisco: Plants Sites, 1995.

SUDECO. 2013. <http://www.sudeco.gov.br/municipios-ride> Acesso em jan. 2016.

TAVARES, Hermes M. Produção flexível e planejamento territorial. In: Revista de Administração Pública, Rio de Janeiro, v. 26(3), 1993.

TAVARES, H. M. Políticas e estratégias industriais e desenvolvimento regional: um estudo comparativo. In: EGLER, Tamara T. C.; TAVARES, Hermes M. (orgs.). Política Pública, rede social e território. Rio de Janeiro: Letra Capital, 2012.

TENÓRIO, Fernando G. Gestão de ONGs: principais funções gerenciais. Rio de Janeiro: FGV, 1997.

THERBORN, Göran. The ideology of power and the power of ideology. Londres: Verso, 1995.

VAINER, Carlos B. Pátria, empresa e mercadoria. Notas sobre a estratégia discursiva do planejamento estratégico urbano. In: ARANTES, O; VAINER, C.; MARICATO, E. A cidade do pensamento único. Desmanchando consensos. Petrópolis: Vozes, 2000.

VALE, M. Conhecimento, inovação e território. Finisterra, XLIV,v. 88, p. 9-22, 2009.

VARGAS; G. M; JATOBÁ, S. U. S.; CIDADE, L. C. Espaço e Economia. Mercator, Fortaleza, v. 11, n.25, p.35-46, 2012. 
VEDOVELLO, C.A; JUDICE, V.M.M; MACULAN, A.D. Revisão crítica às abordagens a parques tecnológicos: alternativas interpretativas às experiências brasileiras recentes. Revista de Administração, São Paulo, p. 103-118, 2006.

VIEIRA, C. R. B.; HAUSER, G. Porto Alegre - a construção de um habitat de inovação. In: XII SEMINÁRIO NACIONAL DE PARQUES TECNOLÓGICOS E INCUBADORAS DE EMPRESA. Anais. São Paulo: 2002.

VIEIRA, S. Indústria de alta tecnologia: reflexos da reserva de mercado e do neoliberalismo em Florianópolis. Florianópolis: UFSC, 1996.

WAINOVA. Worl Alliance for Innovation. Atlas of Innovation. Disponível em <www.wainova.org>. Acesso em mar. 2014.

WALLERSTEIN, Immanuel. O capitalismo histórico. São Paulo: Brasiliense, 1985.

.O sistema mundial moderno. Porto: Afrontamento, v.2, 1996.

WHETTEN, D. A. Interorganizational relations: a review of the field. Journal of Higher Education, v.52, n.1, p.1-28, 1981.

WHITACKER, A. M. Inovações tecnológicas, mudanças nos padrões locacionais e na configuração da centralidade em cidades médias. Barcelona: Scripta Nova, v. 11, n. 245, p.24, 2007. Disponível em <http://www.ub.edu/geocrit/sn/sn-24524.htm>. Acesso em jan. 2016. 


\section{ROTEIRO UTILIZADO NAS ENTREVISTAS}

\section{GOVERNO}

1. Qual o objetivo do Parque Tecnológico Capital Digital?

2. Qual a infraestrutura atual presente no Parque Tecnológico Capital Digital?

3. Quais as ações que estão sendo promovidas para tornar o PTCD atrativos às empresas de tecnologia da informação e comunicação?

4. Quais as instituições, universidades ou centros de pesquisa estão presentes no PTCD?

5. Qual a origem dos recursos financeiros para a construção da infraestrutura atual no Parque Tecnológico Capital Digital?

6. Como estão os avanços na implementação do Parque Tecnológico Capital Digital?

\section{ESTRUTURA PRODUTIVA}

1. Você conhece o Parque Tecnológico Capital Digital? Onde fica?

2. Quais os objetivos do Parque Tecnológico Capital Digital?

3. Qual a área de atuação da sua empresa?

4. Qual o porte da sua empresa?

5. Na sua opinião, onde estão localizadas as empresa de TI no DF?

6. A quem se destinam os produtos da sua empresa?

7. Qual os aspectos ou fatores (em ordem de importância) que levariam a sua empresa a se instalar no Parque Tecnológico Capital Digital?

8. Qual a composição do quadro de mão de obra de sua empresa?

9. Como estão os avanços na implementação do Parque Tecnológico Capital Digital?

\section{INFRAESTRUTURA DE CIÊNCIA E TECNOLOGIA}

1. Você conhece o Parque Tecnológico Capital Digital? Onde fica?

2. Quais os objetivos do Parque Tecnológico Capital Digital?

3. Quais são os seguimentos envolvidos no PTCD?

4. Onde estão localizadas as empresa de TI no DF?

5. Qual o papel do CDT/UnB para o Parque Tecnológico Capital Digital?

6. Como estão os avanços na implementação do Parque Tecnológico Capital Digital?

\section{COMUNIDADE LOCAL E TRABALHADORES NO PTCD}

1. Você sabe o que é o Parque Tecnológico Capital Digital? Pra que serve?

2. O que é produzido no Parque Tecnológico Capital Digital?

3. Quais os profissionais que trabalham no Parque Tecnológico Capital Digital?

4. Você trabalharia nele (PTCD)?

5. Por que o Parque Tecnológico Capital Digital não está pronto ainda?

\section{COMUNIDADE LOCAL (VILA WESLIAN RORIZ)}

1. A presença do Parque Tecnológico Capital Digital alterou o seu dia-a-dia?

2. Você viu algum problema ambiental na construção do parque?

3. Conhece alguém que more na Vila e trabalhe no Parque Tecnológico Capital Digital? 